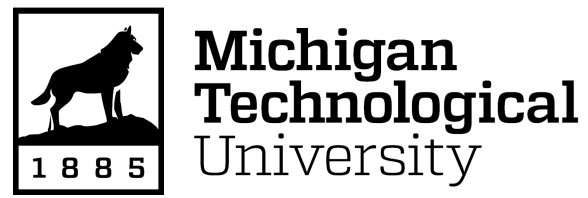

Michigan Technological University Digital Commons @ Michigan Tech

Dissertations, Master's Theses and Master's Reports

2017

\title{
A Landscape of Water and Waste: Heritage Legacies and Environmental Change in the Mesabi Iron Range
}

John Baeten

Michigan Technological University, jpbaeten@mtu.edu

Copyright 2017 John Baeten

\section{Recommended Citation}

Baeten, John, "A Landscape of Water and Waste: Heritage Legacies and Environmental Change in the Mesabi Iron Range", Open Access Dissertation, Michigan Technological University, 2017.

https://doi.org/10.37099/mtu.dc.etdr/407

Follow this and additional works at: https://digitalcommons.mtu.edu/etdr

Part of the Archaeological Anthropology Commons, Geographic Information Sciences Commons, History of Science, Technology, and Medicine Commons, Physical and Environmental Geography Commons, and the Social and Cultural Anthropology Commons 
A LANDSCAPE OF WATER AND WASTE: HERITAGE LEGACIES AND ENVIRONMENTAL CHANGE IN THE MESABI IRON RANGE

\author{
By \\ John Baeten
}

\begin{abstract}
A DISSERTATION
Submitted in partial fulfillment of the requirements for the degree of DOCTOR OF PHILOSOPHY In Industrial Heritage and Archaeology

MICHIGAN TECHNOLOGICAL UNIVERSITY 2017
\end{abstract}

(c) 2017 John Baeten 
This dissertation has been approved in partial fulfillment of the requirements for the Degree of DOCTOR OF PHILOSOPHY in Industrial Heritage and Archaeology.

\section{Department of Social Sciences}

Dissertation Advisor: Nancy Langston

Committee Member: $\quad$ Melissa F. Baird

Committee Member: $\quad$ Don Lafreniere

Committee Member: $\quad$ Fredric Quivik

Committee Member: Arn Keeling

Department Chair: Hugh Gorman 


\section{Table of Contents}

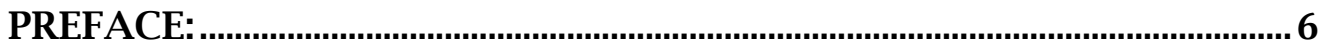

ACKNOWLEDGEMENTS: ...................................................................................

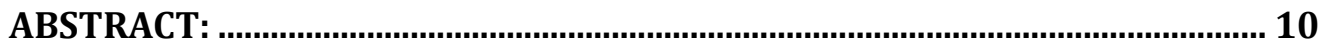

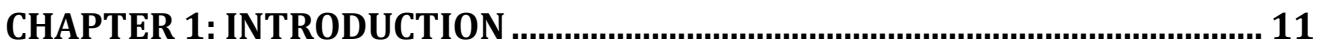

A. HISTORICAL OVERVIEW OF THE LAKE SUPERIOR IRON DISTRICT:..................................11

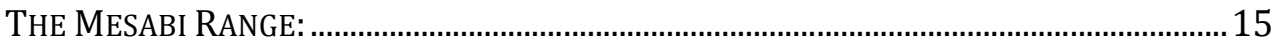

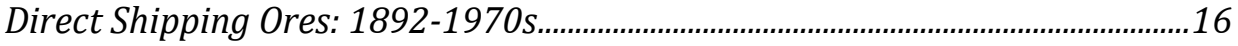

Washable Ores: 1907-1980s.....................................................................................16

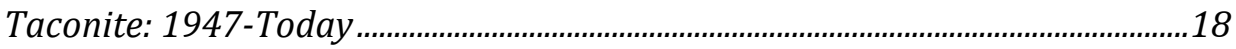

HERITAGE OF THE IRON RANGE.....................................................................................19

LITERATURE REVIEW: .......................................................................................................2 20

MINING HISTORY:.......................................................................................................22

ENVIROTECH LITERATURE: ...........................................................................................26

HERITAGE LITERATURE:_..........................................................................................................31

Collective memory: ..................................................................................................................33

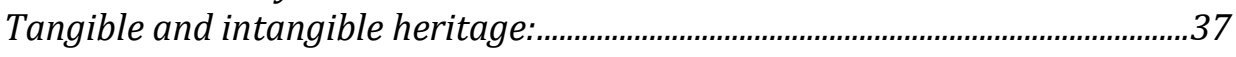

DISSERTATION CHAPTERS................................................................................................ 44

ChaPTER 2 (ARTicle 1): John BAETEN, NANCY LANGSTON, Don LAFRENIERE, "A GEOSPATIAL APPROACH TO UNCOVERING THE HIDDEN WASTE FOOTPRINT OF LAKE SUPERIOR'S MESABI IRON RANGE," THE EXTRACTIVE INDUSTRIES AND SOCIETY, VoL. 3, No. 4 (Nov., 2016) 1031-1045.

ChAPTER 3 (ARTICLE 2): JOHN BAETEN, NANCY LANGSTON, DON LAFRENIERE, “A SPATIAL EVALUATION OF Historic IRON Mining IMPACTS ON CURRENT IMPAIRED WATERS IN LAKE SUPERIOR'S MESABI RANGE," SUBMITTED TO AMBIO: A JOURNAL OF THE HUMAN ENVIRONMENT APRIL 2017.

CHAPTER 4 (ARTiCle 3): JoHn BAETEN, “CONTESTED LANDSCAPES OF DisPlaCEMENT: OLIVER IRON AND THE HibBing MiNing DisTRICT," CHANGE OVER TIME: AN INTERNATIONAL JOURNAL OF CONSERVATION AND THE BUILT ENVIRONMENT (IN PRESS, FORTHCOMING FALL 2017).

ChAPTER 5 (ARTICle 4): John BAETEN, “NeGotiating Mobile Mine WASTE: ENVIRONMENTAL LEGACIES of LOW-GRADE IRON ORE Mining IN MinNeSota's MESABI RANGE," SUBMITTED TO ENVIRONMENTAL HISTORY JUNE, 2017................................................... 47

METHODS................................................................................................................. 48

BROADER RESEARCH PROJECT ...................................................................................... 51

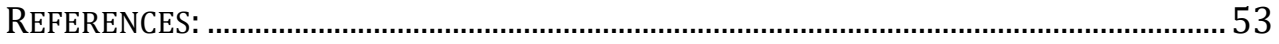

CHAPTER 2: A GEOSPATIAL APPROACH TO UNCOVERING THE HIDDEN WASTE FOOTPRINT OF LAKE SUPERIOR'S MESABI IRON RANGE..............................60

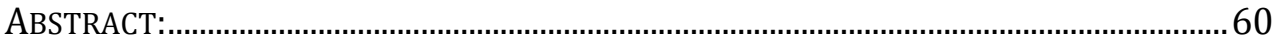

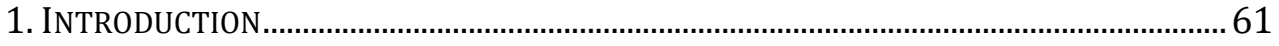

2. THE THREE PHASES OF MINE WASTE ..........................................................................67

2.1 Direct shipping ore wastes ....................................................................................67

2.2 Washable ore wastes....................................................................................................68

2.3 Taconite Wastes ...............................................................................................................71

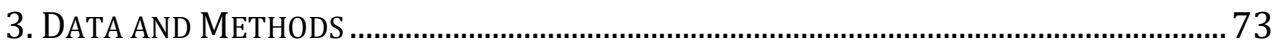

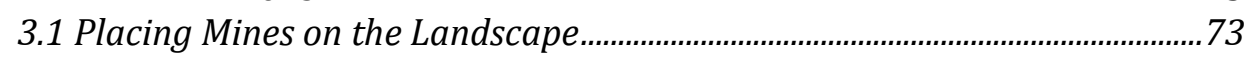




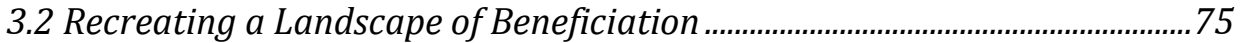

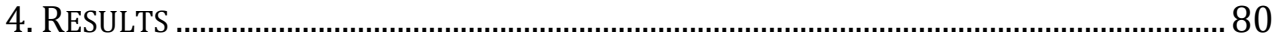

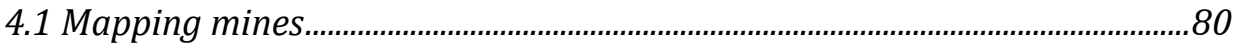

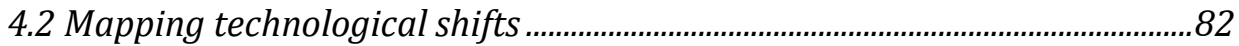

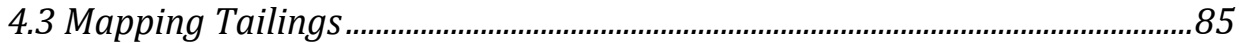

4.4 Mapping Shifting Concentrations of Mining and Waste................................93

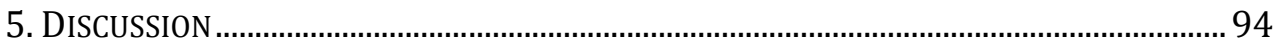

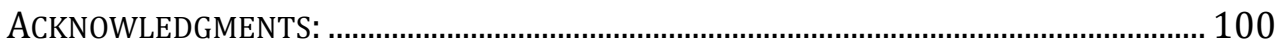

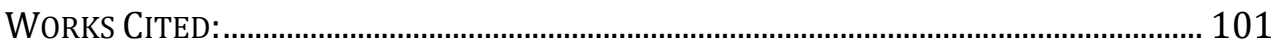

CHAPTER 3: A SPATIAL EVALUATION OF HISTORIC IRON MINING IMPACTS

ON CURRENT IMPAIRED WATERS IN LAKE SUPERIOR'S MESABI RANGE ...............105

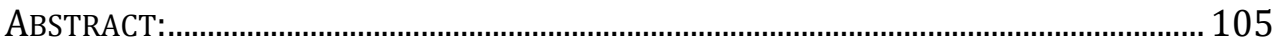

INTRODUCTION:

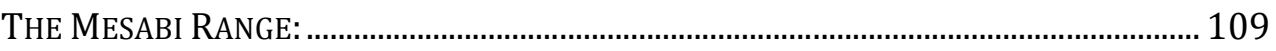

Figure 3.1: Watersheds (HUC-08) of the Mesabi Iron Range. The subwatersheds (HUC-10) are those portions of the watersheds located within the mining region...

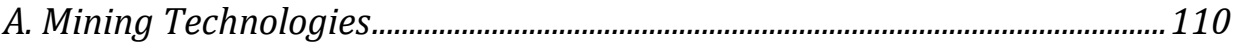

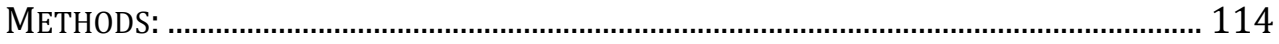

A. Mapping Watershed Boundaries ................................................................114

B. Mapping Mining Intensity...............................................................................115

C. Categorizing Impaired Waters vs. Non-Impaired Waters...............................119

RESULTS:

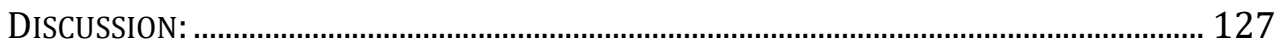

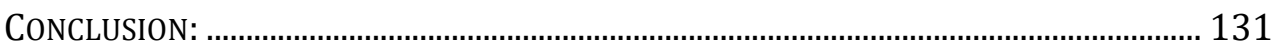

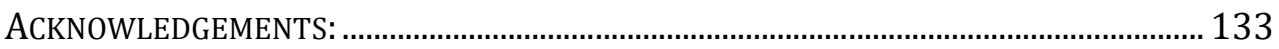

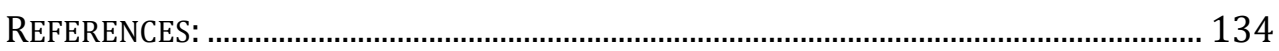

CHAPTER 4: CONTESTED LANDSCAPES OF DISPLACEMENT: OLIVER IRON

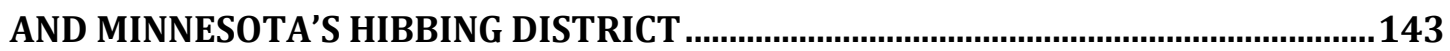

ABSTRACT:

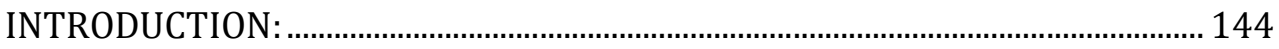

MINING EXPANSION ACROSS THE RANGE .......................................................... 145

MINNESOTA TAX POLICY AND THE RICHEST VILLAGE IN THE WORLD ....... 148

A CONTESTED LANDSCAPE OF DISPLACEMENT: HIBBING AND OLIVER IRON

153

DRAINING A LAKE TO CREATE A MINE: CARSON LAKE ………............................ 159

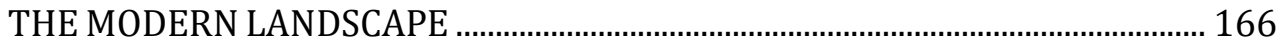

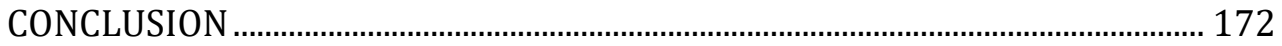

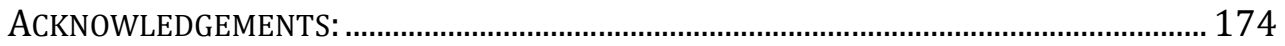

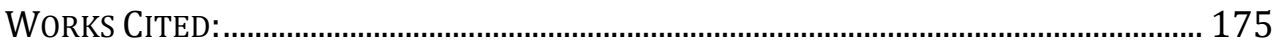

CHAPTER 5: NEGOTIATING MOBILE MINE WASTE: ENVIRONMENTAL LEGACIES OF LOW-GRADE IRON ORE MINING IN MINNESOTA'S MESABI RANGE.181

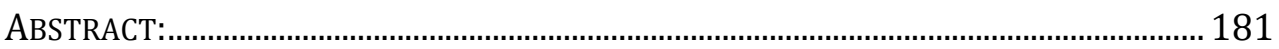

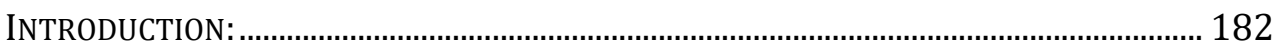

MINING STAGES IN THE MESABI RANGE: ..................................................................... 184

ENVIROTECH PERSPECTIVES ON MINING: .................................................................. 186

THE DEVELOPMENT OF LOW-GRADE ORES: .................................................................... 188 


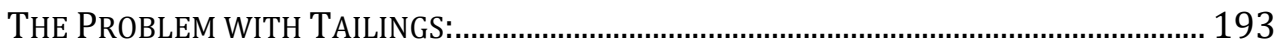

TECHNOLOGICAL ALTERNATIVES: THE O’BRIEN DITCH: .................................................. 199

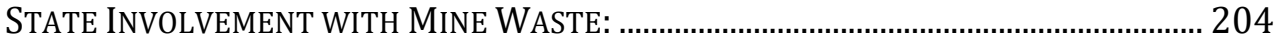

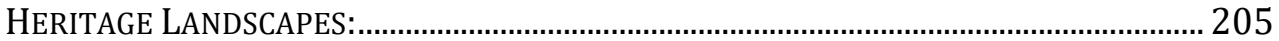

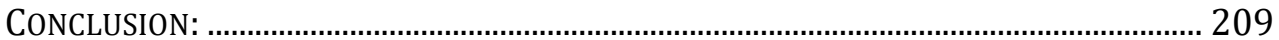

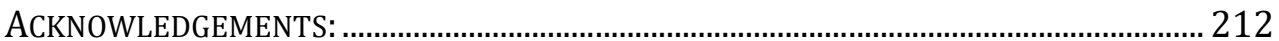

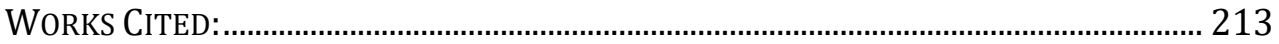

CONCLUSION: A MINE IS MORE THAN A HOLE IN THE GROUND...................221

APPENDIX A: COPYRIGHT DOCUMENTATION..................................................228 


\section{Preface:}

This dissertation consists of five chapters, four of which have been submitted for publication as journal articles. Chapters 2 and 3 were submitted as co-authored articles, while Chapters 4 and 5 were submitted as single authored manuscripts.

At the time of this dissertation's submission, Chapter 2 was published with the Extractive Industries and Society, Chapter 3 was under review with Ambio, Chapter 4 was forthcoming with Change Over Time, and Chapter 5 was submitted to Environmental History. A footnote on the first page of each chapter lists the publishing status, and bibliographic information for the chapter.

I co-authored Chapters 2 and 3 with Nancy Langston and Don Lafreniere, both of whom provided feedback and helpful revisions throughout these chapters. I functioned as the first author for both of these chapters and was responsible for the majority of the data collection and spatial analysis, literature reviews, production of figures and maps, and the discussion of results. In Chapters 2 and 3, Lafreniere wrote the section on historical GIS within the literature review, and in Chapter 3, Langston produced the statistical analysis for the mean proportion of impaired lakes with different types of mining activity. 


\section{Acknowledgements:}

In 1998, as I hung off the back of a garbage truck in Northeast Wisconsin, a dissertation was not in my twenty year plan. This academic and personal journey would not have been possible without the support of my friends, family, former educators and co-workers (including those on garbage trucks, cooking lines, group homes, and archaeological surveys), they have all contributed to my development as a critical thinker, and hopefully a better person.

First and foremost, I am indebted to my advisor, Nancy Langston, whose guidance and support helped sculpt this dissertation into a finished product. Nancy's tireless scholarship, and her ability to use history as a lens to inform current contested landscapes has inspired many of the themes that run through this thesis, as well as my future research questions. I couldn't have hoped for a better advisor.

I am grateful to my dissertation committee, Melissa Baird, Arn Keeling, Don Lafreniere and Fred Quivik, who spent the time reading, editing, and engaging with this research. Don Lafreniere offered continual GIS support, read through more drafts than I would like to admit, and was an excellent co-author on Chapters 2 and 3. I cannot thank Melissa Baird enough for her words of encouragement, reassurance, and overall enthusiasm for this project. Melissa's expertise in critical heritage helped guide much of the heritage focus of this dissertation, and pushed me to challenge the current epistemology of industrial heritage, and offer an environmental perspective.

Fred Quivik continually challenged, and offered helpful suggestions to, my assumptions about mining, technology, and 
heritage, and has opened doors to future research questions. Fred also served on my M.S. committee, and has been fundamental in my development as an archaeologist and a scholar. Arn Keeling graciously agreed to serve as my outside reader, and his research into the environmental legacies of mining inspired much of this dissertation. Arn has continually expressed enthusiasm for my research, and his 'retweets' have served as thoughtful reassurances along the way.

Pat Martin saw potential in me as a Forest Service archaeologist in 2009 when many other graduate programs did not, and brought me on as an MS student in the Industrial Archaeology program in 2010. Pat gave me the opportunity to work on an excellent AML project in Alaska for three academic years, and continually exposed me to new insights in global industrial heritage and industrial archaeology. Paul White has also been a great teacher, co-worker, and friend throughout my academic career.

I thank the excellent scholars who make up the organization NiCHE (Network in Canadian History of the Environment), especially Mica Jorgenson and Jessica DeWitt, who have been my virtual support network and some of my closest colleagues. NIiCHE provided a platform to publish and promote my research to broader publics. I look forward to networking with them at conferences each year, and working with them in the future.

This work was supported by the National Science Foundation (Grant \#R56645, Toxic Mobilizations in Iron Mining Contamination). The Mining History Association also provided a generous research grant. Travel grants from Michigan Tech's Graduate Student Government helped offset some costs when presenting this research at conferences.

The Social Sciences Department and Staff have provided a warm and inviting environment over the duration of my time at Michigan 
Tech. Special thanks to Gina Stevens, Karen Aho, and Amy Spahn for making my time as a graduate student as painless as possible. And lastly, to my partner and soulmate, Tesa Villalobos, I couldn't have done it without you. Thanks for sticking with me. 


\begin{abstract}
:
This dissertation explores the intersection between mining technology, industrial heritage, and environmental history, using iron mining in the Mesabi Range of the Lake Superior Iron District as its core case study. What impact did technological shifts in iron mining and ore processing have on the environment of the Lake Superior basin? How did the environmental changes wrought from low-grade iron ore mining and processing, such as the expansion of open-pits and the production of tailings, affect different communities in Minnesota's Mesabi Range? And finally, how have the environmental legacies of iron mining been remembered and memorialized, or ignored and forgotten?
\end{abstract}




\section{Chapter 1: Introduction}

This dissertation asks: What technological shifts occurred in the mining industry of the Lake Superior iron district, and how did these changes affect the development of the mining industry? What impact did these technological shifts, first from the mining of direct shipping ore to washable ores, and then to taconite ores, have on the environment in the basin, particularly in Minnesota? How did these environmental and industrial changes affect communities? How are these legacies retained on the landscape? How have the technological shifts in mining and the environmental legacies that they produced been remembered and memorialized, and why should we care?

\section{A. Historical Overview of the Lake Superior Iron District:}

Since 1890, the iron mines of the Lake Superior district have been the top producers of iron ore in the United States (Figure 1.1). Steel made from the iron ore mined from the six iron ranges of the Lake Superior district was key to the expansion of industrial development that followed the Civil War. ${ }^{1}$ By 1890, American steel mills purchased more than 50\% of their iron ore from the Lake Superior district, and by the end of World War II, the district's mines accounted for $85 \%$ of the nation's iron ore production. ${ }^{2}$ 


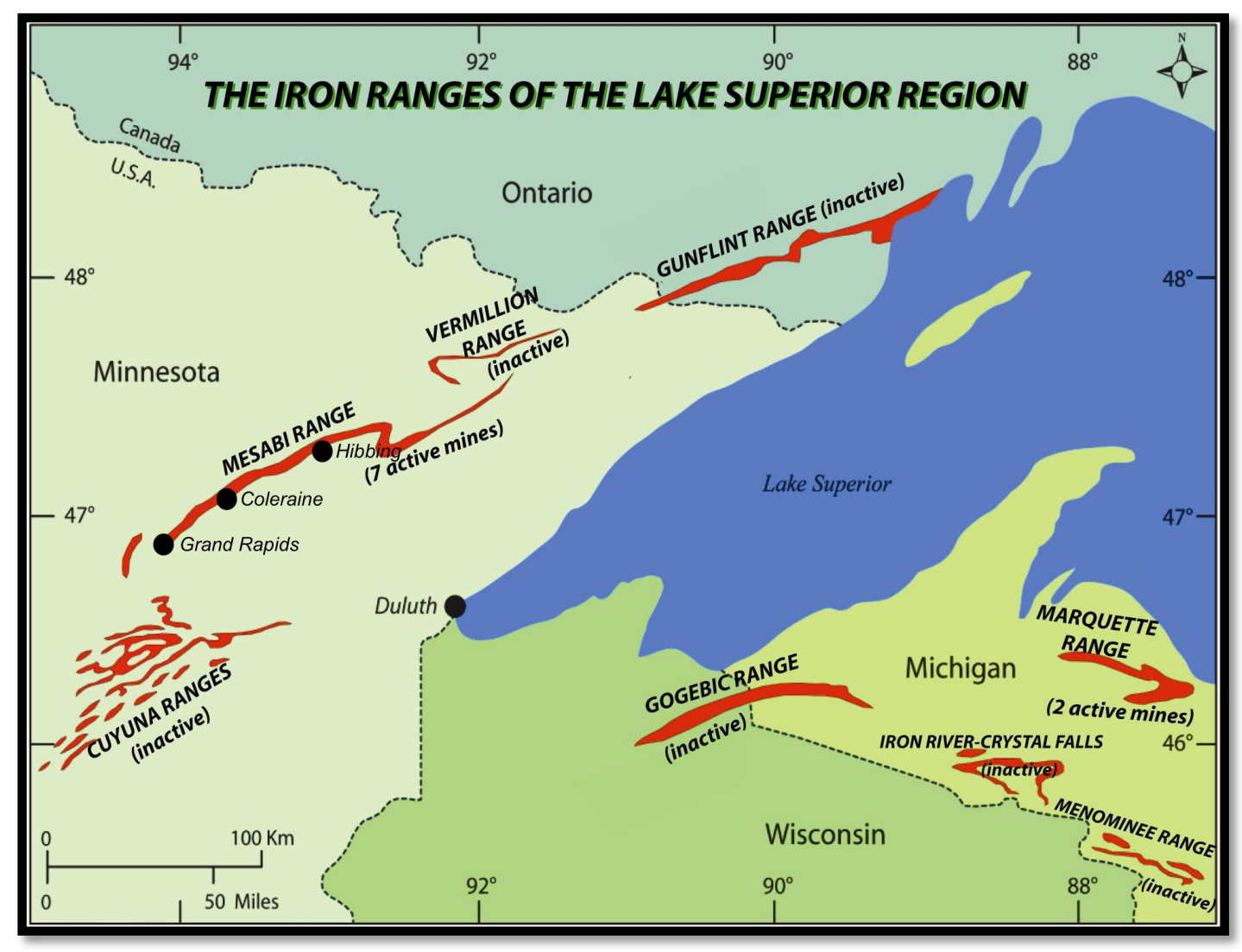

Figure 1.1: Lake Superior Iron District (W.F. Cannon, USGS Report 2014)

The first active mine in the Lake Superior district was opened in 1847 in the Marquette Range. The miners at this mine, the Jackson, extracted high-grade direct shipping ores from a rudimentary open-pit operation. Direct shipping ores contained upwards of $70 \%$ iron, the highest concentration of iron among the ores in the Lake Superior district. These high concentrations meant that mining companies could extract ore from the earth and ship it directly to a furnace without significant further processing. Direct shipping ores were found in every range within the district.

News of the Marquette Range's rich iron deposits quickly spread, and within a few years, moneyed interests from Cleveland began to develop an infrastructure conducive to a successfully 
functioning mining district. In his popular history of the Lake Superior iron district and the Cleveland Cliffs Iron Co., Harlan Hatcher identified several key social factors that led to the early development of the district. ${ }^{3}$ Hatcher points to an existing interest in the region for copper mining, and a rapid investment in the development of a transportation network, which consisted of rail and port facilities, which efficiently moved ore from mine to furnace, and iron from furnace to consumers.

Miners in the first Marquette mines engaged in open-pit mining, extracting visible outcrops of iron ore with hand tools, such as pickaxes. The technological systems employed at these early open-pit mines were designed for shallow ore deposits, which required only a minimal capital investment along with a small workforce. The early iron mining practice in the Lake Superior region was small scale and inefficient. Miners located an outcrop of iron ore and hacked it out with pick-axes. This process created quarry-like pits that could be mined with a fairly small crew of miners, and a minimal capital investment. These open-pit, direct shipping ore mines functioned as the only type of mine in the region up until the 1870s.

The success of the early mines in the Marquette Range spurred a broader interest in the mineral deposits of the Lake Superior region. By 1875 , mining commenced in the Menominee Range, which created a regional competitor to the Marquette Range. Because advanced underground mining technologies, such as diamond drills, had not yet been introduced to the area, early mining targeted only deposits that were visible as surface outcrops. Since many of the deeper iron ore deposits had not yet been mapped, Cleveland Cliffs introduced diamond drills into the Marquette Range in 1870, to aid in surveying and future exploration. ${ }^{4}$ 
Historians Terry Reynolds and Virginia Dawson argue that the Cleveland Cliffs flourished because of a management system that was responsive to the frequently unstable economic climate, something inherent in the mining industry, such as depressed markets, labor shortages, and the inevitable exhaustion of ore. Moreover, Reynolds and Dawson argue that the company had the foresight to adopt new mining methods and technologies when the easily reached ore bodies began to become depleted. ${ }^{5}$ For example, diamond drill technology allowed Cleveland Cliffs Iron Co. to identify the Cliffs Shaft vein at a depth of 400 feet in 1880, which led to extensive geologic mapping of the region and further mineral development. ${ }^{6}$

Reynolds and Dawson point to this development as a critical turning point in the maturation of the Lake Superior iron district. The district shifted from an assortment of small mines, using simple, inexpensive open-pit technologies, to one dominated by a few powerful mining corporations that could afford new technologies that enabled the extraction of deeper mineral deposits. Underground mining technologies also enabled a spatial shift in mining locations within the Lake Superior district. Mine developers gradually progressed westward; first in the Gogebic Range in 1885, next the Vermilion in 1886, and finally the Mesabi Range in $1890 .^{7}$

All of these early mining operations exploited direct shipping ores, but they used different technologies to reach the ore bodies. For instance, in the Vermilion and Gogebic Range, mines were mostly underground. However, by 1893 in the Mesabi Range, large steampowered shovels assisted in the rapid expansion of open-pit mines, beginning in the east and working west. 


\section{The Mesabi Range:}

By 1900, mines in the Mesabi Range became the source of most iron ore produced within the Lake Superior district. Iron mining in the Mesabi Range underwent three technological phases. The first iron mines on the Mesabi Range opened in the 1890s and consisted of high-grade direct shipping ores. ${ }^{8}$ High-grade direct shipping ore mining reached its peak in the 1940s, and began to decline by the 1950s. The second phase began in 1910 with the mining of low-grade washable ores, which continued into the 1980s. The third phase began in 1957 with taconite mining, the lowest grade of iron in the Lake Superior district, a mining phase that continues into the $21^{\text {st }}$ century. ${ }^{9}$ Each of phase of mining produced environmental impacts, evident in the creation of hundreds of deep, open-pit excavations, but they differed in both their scale and spatial extent. Unlike the mining of direct shipping ores, the mining and processing of low-grade washable ores and taconites produced a novel and mobile form of mine waste, called tailings, which often mobilized far from the mines themselves.

What we know about the history of iron mining in the Lake Superior district, and specifically the Mesabi Range, is largely based on studies related to the region's development as a hub for direct shipping ores, or its more recent history as it relates to taconite mining. ${ }^{10}$ Studies related to the second phase of mining, that of washable ores, have received considerably less attention. Overall, these historical studies highlight the need for developing an accurate and detailed representation of the second phase of mining in the Mesabi Range. This dissertation addresses this gap, by connecting the stories of direct shipping ores to taconite by detailing the development of washable ores in the Mesabi Range. 


\section{Direct Shipping Ores: 1892-1970s}

The first iron mines on the Mesabi Range consisted of a mixture of underground and open-pit direct shipping ore mines, primarily located within the range's eastern extent. The machines that were initially brought to the Mesabi, such as steam shovels, were bigger and faster than the equipment employed in the small open-pit mines of the Marquette Range. This technological advantage allowed the mines of the Mesabi Range to commence with large-scale mining from start. Mining historian Duane Smith argues that the shift to massive openpit mining with large steam shovels in the Mesabi Range during the late $19^{\text {th }}$-century acted as a principle factor in the modernizing of American mining methods, and helped bolster the district's role as the leading iron producer in the United States. ${ }^{11}$

The steam shovels used to exploit the open-pit ore bodies in the Mesabi Range could efficiently move massive amounts of earth. These machines allowed mining companies to transition from selective mining of ores to bulk mining, or the indiscriminate removal of vast tracts of earth, and paved the way for the development of low-grade iron ore mining.

\section{Washable Ores: 1907-1980s}

During the 1902-1903 season, mining companies in the Mesabi Range began collecting samples of a massive swath of silica-laden lowgrade iron ores that extended 35 miles, from Hibbing to Grand Rapids, within the Mesabi's western extent. The high proportion of silica in this deposit meant that in order for this material to be merchantable, mining companies first needed to process it before it could be profitably smelted. This process was called beneficiation. While washable ores in the Western Mesabi contained a lower percentage of iron than direct shipping ores, they also contained a higher amount of silica, ranging from $14 \%$ to $25 \% .{ }^{12}$ Contemporary blast furnaces 
required iron ore to contain a percentage of iron around $60 \%$. The washable ore body in the western Mesabi averaged an iron content of less than $40 \%$, meaning that mining companies needed to increase the percentage of iron within these washable ores before they were merchantable. Additionally, when fed into a blast furnace and heated, the abundance of silica found in these washable ores would clog the furnaces with an abundance of a glass-like material called slag.

Although mining companies in the region had not yet developed a technological system to profitably process these lower-grade ores, engineers recognized the potential value embedded in them. Inspired by the success in concentrating low-grade iron ores elsewhere in the United States, in 1903 the Oliver Iron Mining Company, the mining branch of U.S. Steel, sent a carload of western Mesabi ore south, to be tested in a low-grade concentrating plant in Cedartown, Georgia. ${ }^{13}$ The results of this experiment proved favorable, and in 1905, an experimental plant was constructed near Coleraine, Minnesota. Tests at this Mesabi Range plant proved that the washable ores of the Mesabi could be profitably concentrated locally. Owing to its success, the Oliver Iron Mining Company purchased a plot of land south of Coleraine for the construction of a large iron ore concentrator.

In 1907 the Oliver Iron Mining Company began to mine and process the silica-bearing ores of the western Mesabi. The Trout Lake concentrator was designed to treat the washable ores of the Western Mesabi and was located along the eastern shore of Trout Lake at Coleraine. Construction of the Trout Lake Concentrator was completed in 1910, and the first washable ore concentrates were shipped to the port of Duluth. Washable ores were extracted through open-pit, bulk mining technologies, which meant the removal of large swathes of earth. The overburden was dumped at the mine sites, while the ores were shipped to nearby concentrating plants, which first 
classified, then wet washed the ores, using approximately 900 gallons of water to wash the silica from each ton of the iron deposit.

For nearly five decades, the Trout Lake concentrator remained the largest iron ore concentrator in the world, and owing to its success, the washable ore industry in the Mesabi Range soon boomed. By 1920, the Mesabi Range was home to more than 30 washing plants, and by 1930, washable ore concentrates accounted for just under half of the ore shipped from the Mesabi. ${ }^{14}$ Although mining companies were gradually relying more on washable ores to meet the nation's growing demand for steel, direct shipping ores remained important through World War II. The washable ores of the Mesabi Range continued to be extracted and concentrated up until 1980, but in 1947, another low-grade ore, called taconite, shifted the focus of mining in the region.

\section{Taconite: 1947-Today}

After World War II, the focus of mining companies in the Mesabi and state agencies shifted to the lowest grade of iron ore in the region, called taconite. Taconite ores contained only 20-30\% iron, the lowest concentration of iron in the Lake Superior district. Taconite, like washable ores, contained a low percentage of iron, but taconite ores required more intensive and extensive beneficiation technologies to return a profit. Unlike the washable ores that simply required the mechanical removal of silica, taconite processing required more intensive steps, such as fracturing of the mineral deposit at the mine site, fine crushing and grinding of the ore at the beneficiation plant, magnetic concentration, and agglomeration (forming the fine-ground taconite into uniform pellets).

Historian Jeff Manuel argues that the profitable mining of taconite ore was owed to the development of this more intensive and extensive beneficiation system coupled with the passing of a favorable 
tax law. ${ }^{15}$ Since taconite contained such a low concentration of iron, taconite mines needed to extract much more material in order to remain profitable, nearly three times as much as the washable ore mines. Taconite mining companies argued to remain a viable industry, the state needed to modify its current taxation system, and rather than tax the mining industry on the amount of ore removed from the ground, mining companies should be taxed on the value of ore concentrates produced.

Since the technological system used in taconite mining and processing handled so much more material than the system used to concentrate washable ores, the environmental footprint of taconite mining was more extensive than either direct shipping ores or washable ores. Today, taconite ores continue to be extracted in the Lake Superior iron district, while the direct-shipping and washable ores were exhausted decades ago. While the development of the taconite industry helped the Mesabi Range stay afloat during the tumultuous waves of mine closures that began in the 1960s, it also produced new environmental consequence for the region.

\section{Heritage of the Iron Range}

Within the Mesabi Range, low-grade and open-pit iron mining have produced landscape-scale transformations, where environmental legacies, such as tailings piles, open-pit scars, and abandoned mines persist as the dominant mining feature on the landscape, referred to here as the wastescape. Today, there is a larger surface extent of mine waste and mine-pit scarring on the landscape than the Mesabi formation itself. Yet these environmental legacies remain overwhelmingly under recognized by Mesabi Range heritage organizations. ${ }^{16}$ The reasoning for this lack of heritage recognition is multifaceted, produced from both physical transformations, such as 
successive mining efforts that reworked much of the landscape, and abandoned mine land reclamation efforts that concealed much of the wastescape through remediation and revegetation, as well as through perceptual constructs, such as a cultural discourse that has categorized the physical nature of the Mesabi wastescape as either benign or static.

However, I argue that both archival records and current environmental datasets show that the environmental legacies produced from iron mining in the Mesabi Range produced landscapescale impacts, in such ways as the discoloring of lakes (Chapter 5) and contributing to landscape-scale water impairments (Chapter 3). While heritage organizations today may fail to recognize the cultural significance of the landscape-scale transformations produced from Mesabi Range iron mining, archival records show that Iron Range communities have a long history of contesting these environmental transformations. The cultural significance of mining waste and the wastescape produced from Mesabi Range mining are a primary focus of this dissertation.

\section{Literature Review:}

The focus of this dissertation is multidisciplinary, exploring the intersection of mining history, industrial heritage, and environmental history. I engage with 3 core literatures: mining history, envirotech theory, and critical heritage.

The extraction of ore is the focus of the metal mining industry, and to understand why the mining industry has developed the way it has, it is important to understand the term ore. Ore is an economic term, used to describe a metalliferous deposit which contains value, and which upon extraction, can yield a profit. ${ }^{17}$ The focus of this dissertation is centered on low-grade iron ores within the Mesabi 
Range, mineral deposits that were technically not ores until 1910 (washable ores) and 1947 (taconites) respectively. To be considered an ore, these low-grade deposits required a technological system, beneficiation, which would allow for their profitable extraction. Since the meaning of ore is dependent on both technological availability and economic markets, what is considered an ore today, might be considered waste, or gangue (a valueless mineral byproduct of mining) tomorrow, and vice-versa.

\section{Mining History:}

Literature exploring the development of the American mining industry has ranged from business and technological histories, to labor studies and environmental histories. This dissertation contributes to the technological and environmental branches of the field, examining how shifts in mining technology within the Mesabi Range resulted in landscape-scale transformations that communities, the industry and the state needed to negotiate. Political decisions were essential for the historical growth of the American iron mining industry, especially as they related to the development of massive mining corporations. Harlan Hatcher, Terry Reynolds and Virginia Dawson, have examined the growth of the Cleveland Cliff Mining Co., primarily in the Michigan's Marquette Range, while Jeffery Manuel analyzed the Reserve Mining Co.'s development of taconite technology, and Nancy Langston has examined the policy decisions that allowed Reserve to dump tailings into Lake Superior. ${ }^{18}$ In Chapter 4, I analyze political decisions made at the Minnesota state level in response to the boom in mining witnessed in Minnesota during the early 1900s. This state policy consisted of the enactment of an ad valorem tax placed on the iron industry, which levied taxes on the mining companies for not just the ore removed from the ground, but 
the total value of ore estimated in their claims. I then chart the subsequent dispute that occurred between the mining industry and the state over this tax during the 1910s.

I also highlight the role that massive corporations, such as U.S. Steel and International Harvester, had in the development of beneficiation technologies in the western Mesabi Range. In Chapters 4 and 5, I analyze the historical political economy in which the Oliver Iron Mining Co. and Wisconsin Steel contextualized the iron industry as a public utility, and argued for their right to displace communities and to pollute watersheds. This analysis bridges the histories of direct shipping ores to taconite, and illuminates how historical decisions within the washable ore industry helped pave the way for the taconite industry decades later.

As iron mining in the Mesabi Range developed, the region witnessed an increase in landscape-scale transformations, such as expanding open-pit mines. Owing to the horizontal arrangement of the Biwabik formation, Mesabi Range mining companies engaged primarily in open-pit mining, a similar geological occurrence as witnessed in Asbestos, Quebec. In both the Mesabi Range and Asbestos, the increase in open-pit mining meant that communities faced a shrinking physical residential landscape coupled with an expanding and dangerous industrial landscape. As Jessica Van Horssen argues in her study of Asbestos, the expanding open-pits signified increased economic benefits to communities, but they also represented displacement. In order to enjoy these economic benefits, communities often had to weigh how they valued the physical sense of place that was tied to their community against mine expansion and continuing employment. ${ }^{19}$ High rates of physical displacement from expanding mine excavations effect mining communities across the globe. This phenomenon is described as mining induced displacement and 
resettlement, and is primarily analyzed in contemporary developing nations. ${ }^{20}$ My analysis of the mining induced displacement and resettlement that affected Hibbing and Carson Lake in Chapter 4, adds to this literature, and highlights how communities in the Mesabi Range negotiated displacement in the 1910s. This examination provides an additional historic context to the ongoing landscape negotiations that occur between communities and the mining industry.

Throughout this dissertation, I address a concern that geographer David Robertson raises regarding a majority of research within mining history. Robertson argues that many mining histories conclude prior to examining a region's post-mining landscape, and instead, produces a narrative that highlights a "rich past, but inconsequential future." ${ }^{21}$ This omission fails to address the persistence of both the individuals who continue to live within these post-mining communities, as well as the environmental legacies that remain within the landscape after extraction and ore processing cease. Manuel's concluding chapter on the heritage strategy laid out by the Iron Range Resources and Rehabilitation Board addresses this gap for mining histories set in the Mesabi Range. However, Manuel's focus is primarily economic in nature, examining state strategies aimed at revitalization. In Chapters 2, 4, and 5, I analyze the post-mining landscape as a palimpsest, which reflects both loss and conservation within the built and natural environment, and tells a broader ecocultural history of extraction. Additionally, my examination of the social forces that shaped the mining landscape engages with a prominent thread of cultural geography, a theme I address throughout this dissertation by using historic datasets and archival materials to inform our understanding of the modern mining landscape.

Historical geographer and mining historian Richard Francaviglia argues that mining landscapes are often hybrid, produced from the 
introduction of new technologies that rework and destroy historical landscape features. ${ }^{22}$ Hybrid mining landscapes occur when successive waves of new technologies ultimately replace the footprint of existing and obsolete technologies. In Chapter 2, I show that the historical footprint of mining on the Mesabi Range was subjected to a series of technological changes, resulting in a landscape that shows abandonment, the re-working of historical waste piles with new technologies, and the rehabilitation of the mining landscape by the state. My work in mapping landscape change and reconstructing the historic mining landscape provides a practical contribution to Francaviglia's theoretical approach to mining landscapes.

Francaviglia categorizes the development of the mining landscape into five chronological periods, representative of a changing technical system: exploration, or the prospecting stage; initiation, or the boom stage of mining when the highest-grades of ores are exploited; diversification, when miners begins to adopt new technologies designed for specific ore bodies; intensification, when low-grade ores are exploited and waste piles are reworked; and finally cessation, when the mine ceases functioning as a profitable enterprise. ${ }^{23}$ This dissertation argues that the Mesabi Range was shaped by successive stages of mine development and mine abandonment, which helps to illustrate why today we see a larger density of tailings piles and expansive open-pits, then shaft houses and washing plants.

To interpret the social forces that led to the development of the Mesabi landscape, I use a variation of historian Thomas Hughes' systems-approach, which illuminates many of the blurry lines that distinguish between the social, material, and environmental components that led to the development of the mining landscape. ${ }^{24}$ First are the human system-builders: actors who identified deposits of 
ore, staked claims, employed miners and developed interest in these mining districts. Systems-builders generated economic support for the mining endeavor and lobbied within local and state-level political arenas to legitimatize and build momentum into their mining venture. ${ }^{25}$ In the Mesabi, these system-builders included the geologists who explored the region during the 1850s, the numerous land-holding agencies that leased mineral rights to mining companies, and the scientists who constructed social networks with metallurgists in the American Southeast to bring low-grade ore concentrating technologies to the Lake Superior district, an element I discuss in Chapter 5.

Second are the material technologies within the mining landscape. In the Mesabi, these include the rail lines, ore conveyors, washing plants, and tailings basins, which represent human expertise and knowledge. This expertise is seen in the professionalization and education of mining engineers and mine superintendents, as well as with the incorporation of chemists and metallurgists in the mining industry..$^{26}$ Additionally, as more efficient technologies were introduced to a region, the abundance of redundant machines, transportation systems, and structures within the mining landscape represents a changing production of knowledge. In the Mesabi Range, this changing production of knowledge occurred during the shifts from direct shipping ore, to washable ore, and to taconite. Throughout this dissertation I analyze the material technologies that shaped the Mesabi mining landscape, including the ones that still remain embedded within it.

Third, and the most lasting remnant of the mining landscape, are the visible and invisible environmental and social impacts of mining, seen in such features as tailings ponds, mine subsidence, and community abandonment, as well as the invisible impacts that manifested in ground water pollution, asbestos contamination, and 
the consumption of communities from the expansion of open-pit mines. In the Mesabi these impacts include tailings ponds, mine-pit lakes, abandoned communities, and modified hydrological systems. In Chapters 2, 3, and 5 I highlight the many legacy effects that continue to affect the environment of the Mesabi Range and the sheer physical extent of the current wastescape.

\section{Envirotech Literature:}

Envirotech is a branch of history that studies the intersection of the history of technology and environmental history. Studies in envirotech embrace the concept that technology and the environment are interdependent of one another - that both actively shape each other. Mines represent envirotechnical systems, that is, mines consist of natural systems, such as ore bodies, which mingle with technological systems, such as steam shovels - meaning that mines are much more than simply a hole in the ground. Within envirotech, the extraction of metals and minerals has received significant attention. Kathleen Morse's The Nature of Gold, Thomas Andrews' Killing for Coal, Timothy LeCain's Mass Destruction, Fredric Quivik's dissertation Smoke and Tailings, and Kent Curtis' Gambling on Ore, all touch on the connection between miners, the geology of the mines, the economic and political agency that led to the mines themselves, and the changing technology used to extract, process, and transport ore. ${ }^{27}$ This dissertation contributes to this literature by providing an envirotech perspective to the production of, and negotiation over, mobile mining waste in the Mesabi Range.

Using an envirotech perspective, I argue that the mining landscape can be read as an eco-cultural narrative where abstract human agency, physical technologies, and ecological functions intersect to produce environmental and landscape transformations. 
My central thesis, that open-pit and low-grade iron ore mining produced landscape-scale transformations, broadly contributes to envirotech literature by illuminating the historical processes that have effectively shaped the current landscape, such as the migration of mine tailings and the displacement of communities from open-pit excavations. Furthermore, since waste serves as a core focus of this dissertation, my research highlights how historical technological decisions led to an abundance of waste on the current landscape.

A large part of this dissertation is focused on the technological system used to concentrate low-grade ores into a profitable commodity, or beneficiation. Beneficiation technologies in the Mesabi Range, converted something viewed as waste to earlier mining companies, such as washable ores and taconite, into a resource that later mining companies could profit from. Throughout this dissertation I argue that beneficiation technologies employed in the Mesabi Range not only converted the physical nature of ore, through mechanical concentration processes, but they also converted the abstract value of the mineral deposit from something valueless to something valuable. Envirotech scholars Sara Pritchard and Thomas Zeller argue that mining technologies, such as low-grade ore concentrators convert "nature into natural resources," meaning that mining technologies can convert geological deposits into physical commodities. ${ }^{28}$ This technological conversion alters the way in which the mining industry values the environment, with economics dictating which and when mineral resources have value.

Historian Timothy LeCain's examination of low-grade copper mining in the Western United States is perhaps the most cited envirotech study related to mining. In Mass Destruction, LeCain uses the term "mass destruction" to juxtapose with mass production, to illuminate the technological systems designed to extract low-grade 
ores. ${ }^{29}$ LeCain argues that these mining technologies were engineered to extract vast quantities of material indiscriminately and efficiently, which contrasted from technologies used in traditional selective mining operations. LeCain credits the "economies of speed" built into these massive machines for the increased throughput necessary in the development of bulk-mining low-grade ores. LeCain argues that openpit mining technology allowed mining engineers to effectively rationalize and systematize a natural system so that "nature itself was a factory carved out of natural stone." ${ }^{30}$ I argue that the horizontal orientation of the Mesabi Range allowed for the early introduction of open-pit mining technologies, a technological system that provided mining companies with the means to eventually extract the region's large swathes of low-grade washable and taconite ores.

This dissertation adds to LeCain's focus on extractive technologies by bringing an envirotechnical perspective to ore processing. LeCain argues that exhaustive open-pit mining practices "shifted much of the cost of industrial mining to the environment." ${ }^{31}$ I argue that the processing of low-grade ores in the Mesabi Range placed new demands on the environment, specifically in the consumption of water and the production of waste at beneficiation plants. Additionally, I argue that low-grade ore concentration produced new environmental impacts at new spatial locations, mainly through the disposal of tailings. In Chapter 2, 3, and 5, I show mining companies disposed of tailings, through the direct dumping into lakes, and how these tailings often migrated from where they were dumped, which extended the environmental footprint of mining far from the mines and plants themselves.

Unlike the massive holes in Utah and Montana that make-up LeCain's study, the historic footprints of many of the facilities used to concentrate low-grade ores in the Mesabi Range are less obvious on 
the current landscape. In Chapter 2, I analyze the modern Mesabi landscape to examine what elements of the envirotechnical system used to process low-grade ores remain. I find that a majority of Mesabi Range beneficiation plants have been removed from the landscape and are no longer visible, yet these facilities have produced lasting environmental footprints, evident in overgrown roads, scattered debris, and mining waste - iconic landscape features of the Mesabi mining system.

These lasting environmental legacies are what historical geographer Craig Colten refers to as a "technological by-product" of the mining industry. ${ }^{32}$ These by-products, such as waste rock and overburden piles, are landscape features Colten finds indicative of a region's industrial past. In Chapter 2, I spatially analyze the extent and location of these valueless by-products in the Mesabi Range, arguing that they were deposited across the Mesabi Range, both at mine sites and at concentrating plants, while the valuable ore and mining profits were exported out of the region. I argue that because the majority of the concentrating plants located in the Mesabi were scrapped decades ago, and more than half of the mines are now lakes, these technological by-products, such as tailings basins, serve as some of the last physical vestiges of the Range's industrial past.

Joel Tarr's The Search for the Ultimate Sink: Urban Pollution in Historical Perspective highlights the historical decisions and environmental trade-offs that were made in engineering the technological systems designed to manage urban waste streams. ${ }^{33}$ Tarr shows that in order to understand the waste system, you need to examine more than just the system's end, but look at the entire system. This dissertation builds on Tarr's work by showing that the mining industry produced a great volume of waste across the Mesabi Range. Additionally, I argue that understanding how and where this 
waste was produced, where it was deposited, and where it ended up, are important factors in understanding the envirotechnical system that shaped the landscape. I show that not all waste was produced equally. Taconite tailings differed from the tailings produced by washable ores, in both their content as well as their consistency. Taconite ores were subjected to a much more intensive beneficiation process, including crushing and fine-grinding, which made the tailings a much finer grain than those produced during washable ore processing, which allowed taconite tailings to migrate more easily and at further distances than washable ore tailings.

The waste produced from iron ore mining has often been portrayed as being fairly benign. ${ }^{34}$ Nancy Langston's analysis of taconite tailings shows that this perception is not always accurate. Sulfides were present in overburden piles at some taconite mines, causing acid drainage. Taconite processing sometimes produced tailings containing asbestiform fibers, the classic example being tailings from the Reserve Mining Company that migrated into Duluth's drinking water supply. The beneficiation of taconite ores also produces atmospheric mercury, accounting for the primary source of mercury contamination produced within the Lake Superior basin. ${ }^{35}$ In Chapter 5, I show that washable ore tailings also produced tremendous environmental impacts, including the discoloring of an entire lake. Additionally, drawing on the recent iron ore tailings disaster at the Brazilian Bento Rodriguez mine, I show that the sheer quantity of tailings on the landscape create an impact themselves,

I show that the technological system used in taconite mining and processing mirrored the system used with washable ores, but on a larger and more expansive scale. The taconite process dug up larger swathes of land, required more water to process the ore, and produced significantly more tailings than the concentrating plants 
that treated washable ores. Contrasting with the inland tailings basins employed at washable ore concentrators, the Reserve Mining Company's located their taconite plant at Silver Bay on the western shore of Lake Superior, which served as a massive sink for the plant's tailings. As John Thistle and Nancy Langston argue, the environmental consequence of taconite mining had effects that were widespread rather than localized and required legal intervention in order to thwart these burgeoning impacts. ${ }^{36}$ My examination of the migration of tailings at Swan Lake in Chapter 5 adds to the story of waste escaping the tailings controls engineered by Minnesota mining companies and highlights the dynamic nature of the environment within the envirotechnical system, which highlights the agency of nature within these mining systems.

\section{Heritage literature:}

Mining landscapes such as the Mesabi Range are messy, busy, and confusing. They are hidden in the subterranean environment and exposed on the surface. They represent a continuum of changing human values, changing technologies, and changing environmental responses to these technologies. Mining landscapes are not static, but organic, resulting in a mixture of pathways, obsolete structures, and the technological rework of older landscape features. From an environmental viewpoint, mining landscapes can be seen as dangerous and toxic, hazardous blights representative of a capitalist ethos. On the other hand, mining landscapes read through a cultural heritage perspective might be seen as surreal or sublime, value-laden reminders of the past, representative of a community's identity.

In addressing the research questions within this dissertation I engage with critical heritage literatures that question the political, cultural, and ontological foundations of collective memory and 
heritage studies. In this dissertation, I use a critical heritage perspective to challenge two tenets of the current heritage practice as it relates to industrial landscapes. Industrial heritage organizations in the United States have typically focused on either the selective preservation of the built environment (generally that of worker's housing, machines, and large industrial facilities) or the promotion and development of heritage tourism industry rooted in either technological or economic nostalgia. ${ }^{37}$ I argue that both of these approaches promote a distorted collective memory of a region, addressing only a fragment of a region's complex past. While many industrial heritage organizations have drawn on labor history and recognize the conflicted past that occurred between management and workers, the recognition of the relationship that occurred between industry and the environment has been under- represented..$^{38} \mathrm{I}$ argue that because the environmental legacies of industrialization are the most ubiquitous cultural feature within an industrial landscape, they deserve recognition, interpretation and analysis from heritage practitioners.

Second, I argue that the preservation of cultural heritage does not need to be the primary goal for heritage professionals, and instead, that recognition, interpretation, and analysis are equally important objectives. Current industrial heritage scholarship related to mining argues that waste features preserved in situ have value because they articulate with the broader cultural landscape and provide an historical context regarding the technological systems employed within that given landscape. ${ }^{39}$ While previous heritage studies have explored the value of mine waste and toxicity as they relate to preservation efforts, such as in the retention of tailings and slag heaps, my attention is placed on the inherent value found within these vast environmental legacies produced from past industrial 
activities, as features that future generations can learn from, whether they are remain on the landscape or not. ${ }^{40}$

\section{Collective memory:}

I analyze mining heritage in the Mesabi Range through a critical heritage lens, and examine both the historical narratives told about the Range and what elements of the region's collective memory have been preserved and promoted by heritage organizations. I find that historical narratives and collective memory shape each other reciprocally. Analyzing the historical narrative of the Mesabi Range reveals a comprehensive historical narrative of iron mining in the Mesabi Range, including a detailed account of the development of direct shipping ores, the ethnic make-up of mining communities, labor unrest within the mining industry, and the transition to taconite mining ${ }^{41}$ However, there are notable omissions, including an account of washable ore mining and processing, an overview of how communities contended with the landscape-scale transformations brought about from iron ore mining, and how new forms of waste were negotiated within the region. My research adds to this historic narrative by filling in these gaps.

A critical heritage perspective calls into question the ways in which heritage is studied, interpreted, practiced, and valorized. I argue that in the Mesabi Range, and many other industrial heritage sites, the collective memory promoted by heritage organizations glosses over the region's complex history of negotiation and discourse, lived experience, and how the historical impacts of these places continue to shape the contemporary environment and communities. Instead, we see a concerted effort by heritage organizations to promote the region's past through the lens of tourism-driven nostalgia. Anthropologist and heritage specialist Laurajane Smith argues that the 
collective memories promoted by heritage organizations, such as those found in the Mesabi Range, influence our worldviews:

The discourses through which we frame certain concepts, issues or debates have an affect in so far as they constitute, construct, mediate and regulate understanding and debate. Discourse not only organizes the way concepts like heritage are understood, but the way we act, the social and technical practices we act out, and the way knowledge is constructed and reproduced. ${ }^{42}$

Heritage-driven organizations in the Mesabi Range promote the region's industrial heritage through a discourse that reflects historical policy directives, technological and economic nostalgia, and an emphasis on the enduring strength of mining in the region - as both an industry and as a pillar of the Range's identity. The primary agencies that promote the Range's mining heritage are: the Iron Range Resources \& Rehabilitation Board, the Minnesota Discovery Center, and various local historical societies. Historian Jeffrey Manuel argues that these organizations developed a heritage tourism strategy in the Mesabi Range as an avenue to revitalize the economy as the region faced industrial decline in the late-1970s. ${ }^{43}$

Manuel argues that these agencies were faced with a dilemma: should they promote a heritage of the region that draws on the Range's rich mining past, or should they emphasize the resiliency of the region in an effort to attract new industry? Manuel suggests that after much negotiation, the historical narrative that the Minnesota Discovery Center agreed on was one that promoted the region's mining history through a discourse that told "a nostalgic history of the Iron Range that simultaneously celebrated an industrial past while moving forward into a postindustrial future." ${ }^{44}$ My research finds that in addition to the efforts of the Minnesota Discovery Center and the Iron Range Resources and Rehabilitation Board, state agencies, such as 
the Minnesota Department of Natural Resources (MNDNR), also played a critical role in developing the heritage discourse of the Mesabi Range. In Chapter 4, I show that like the IRRRB, the MNDNR also sought to revitalize the region by reimagining the Range, both physically and conceptually. I argue that the MNDNR sought to transform much of the physical mining landscape, through mine land reclamation efforts, and to rethink the conceptual landscape of the Mesabi, by promoting the regions as a recreational paradise instead of a deindustrialized region.

This heritage discourse represents an aspect of what Smith refers to as "authorized heritage discourse," a management tool used to legitimize official institutions to promote a specific meaning of the past, defining what aspects of heritage they wish to promote, and who should be able to speak for it. I argue that in the Mesabi Range, the authorized heritage discourse has been used as a tool aimed at revitalizing the local economy, and has obfuscated many of the hurtful heritages, whether social or environmental, of the region.

A large and growing literature in critical heritage studies have explored how debates, like the ones faced by heritage organizations in the Mesabi, have been negotiated ${ }^{45}$ What elements of a region's past should receive heritage recognition? Who should be chosen to speak for these diverse heritages? While Smith calls this authorized heritage discourse, Rodney Harrison defines this process as "official heritage," while Jon Price refers to it as "top-down" management, and Alice Mah calls this "official collective memory." Although these scholars refer to these heritage processes by different names, they all argue that the heritage process often does not play out in a democratic arena, but instead, bureaucratic decisions tend to shape the recognition process. I argue that within mining landscapes in the United States, and within 
the Mesabi Range specifically, the heritage recognition process has consistently underrepresented the environmental legacies of mining.

Sociologist Alice Mah describes collective memory as a living process that embodies "the shared and socially constructed memory of a group of people, as opposed to individual memory." ${ }^{46}$ In the Mesabi Range, my research shows that the policies derived from the Iron Range Resources and Rehabilitation Board and the Minnesota DNR during the 1970s, have had a lasting influence on the stories retained in the region's collective memory, and these do not reflect a living process, but one that continues to draw on initiatives enacted decades ago. I argue that the heritage discourse in the Mesabi Range and in other mining landscapes has been anything but a lived experience, as much of what is regarded as being important today derives from decisions made decades ago and often does not engage with contemporary critical issues, such as environmental consequences.

Rodney Harrison argues that heritage is "formed in the present and reflects the inherited and current concerns about the past." ${ }^{37}$ I argue that heritage concerns voiced by the industrial heritage community have failed to account for the direct and indirect impacts on the environment. Technological failures within historic and contemporary mining sites have resulted in three of the largest human-caused environmental disasters of the past five years. ${ }^{48}$ As an industrial heritage scholar, I argue that present concerns over historical and contemporary mining sites are justified, and, for industrial heritage to stay relevant, the official heritage discourse needs to be reflective of these concerns.

My research highlights the widespread landscape scale transformations that occurred and remain in the Mesabi Range as a result of open-pit and low-grade iron ore mining, and suggest that 
these transformations should be given more heritage consideration. Collective memory and historical narratives need to be reexamined and challenged, as they both influence what we know, and what we value, about landscape, identity, and heritage.

\section{Tangible and intangible heritage:}

In addition to being influenced by historical narratives and the authorized heritage discourse, collective memory is also shaped by our surroundings, and what we see on the landscape. This dissertation shows that the built environment of the Mesabi Range has undergone dramatic changes over the past half-century. More than half of the open-pit mines that made the Range famous now exist as lakes, and are managed as recreational area by the MNDNR, rather than as cultural resources. Additionally, my research shows that of the nearly ninety processing plants that once dotted the Mesabi's nearly 100-mile stretch, today, only a handful remain visible. My research into this landscape transformation adds to what anthropologist Mikkel Bille and Lynn Meskell call the presence of absence. Bille argues that "what may be materially absent still influences people's existence of the material world" - "that something can be there even though it is not there." ${ }^{49}$ In the Mesabi Range I argue that although the beneficiation plants are no longer physically present, and the mines are no longer conceptually present (since they are managed as lakes), their legacies remain embedded on the landscape.

The presence of absence affects collective memory - in the Mesabi Range I show that the removal of beneficiation plants makes it difficult to articulate where much of the waste on the modern landscape originated. Meskell argues, "More redolent are the spaces and scars that signify, not only the object that once was, but the very process of object absence, disappearance or decay." ${ }^{50}$ In this dissertation, I explore the footprints of these absent beneficiation 
plants through the analysis of historical and contemporary aerial imagery, as well as remote sensing LiDAR data, which adds an empirical perspective to Meskell's theoretical argument. Furthermore, this analysis shows that the removal of beneficiation plants in the Mesabi Range has made the broader mining landscape seem disparate and unconnected, where mining features, such as tailings basins, seemingly exist as islands, as the visible technological systems that created them have been removed from the landscape altogether. Cushioning the presence of absence argument, my research shows that the environmental legacies of mining persist much longer than the facilities that produced them, remaining embedded in the landscape in the form of industrial waste, landscape modification and community memory.

Heritage specialist Emma Waterton argues that material remains often shape our ideas of heritage; that those visible objects which we assign heritage significance to and recognize as being meaningful, often promote a one-sided vision of a polymorphous history. Waterton contends, "Its objects - its things - gave substance to its ideals, and proved that they were real. They did secret work, beyond their material significance and beyond their aesthetic value, to create an illusion, of one past, among a possible many." ${ }^{{ }_{51}}$ In Chapter 4, I examine a monument constructed to memorialize North Hibbing, a town on the Mesabi Range that was displaced from an expanding open-pit. The memorial does "secret work", promoting the technological achievement of the mining company - the fact that the company was able to successfully relocate 15,000 individuals in 1920, but it obfuscates the contentious past between Hibbing community members and the Oliver Iron Mining Co., and the fact that this move was deeply contested. 
Memorialization is a principle function of the official heritage process. In the United States, cultural landscapes that have experienced hurtful, contested, and painful pasts, such as Civil War battle fields, terrorist attacks, and natural disasters, are often recognized by some type of memorial, whether it be a roadside marker, monument, or an official visitor's center. Geographer Kenneth Foote's comprehensive study of the connection between landscape, identity, and hurtful heritages shows that memorialization functions as a way to both imprint elements of the past onto our collective memory and ascribe cultural meaning to a physical place. ${ }^{52}$ In terms of industrial landscapes, Foote's study shows that memorials have been erected to observe the conflicts that arose between labor and management, such as the Haymarket Martyrs Monument and the Lattimer Mines Massacre, but Foote also shows a notable absence of heritage memorials erected to observe environmental damage, contamination and community displacement - features which are widespread across mining landscapes, and which I argue in Chapters 2, 4, and 5 deserve memorialization.

Although an expanding open-pit displaced all but two towns on the Mesabi Range, only the historic location of North Hibbing has been memorialized. In his 1992 thesis, historian Walter Thurman argues that the immediate effect that open-pit mining had on communities in the Mesabi Range was widespread. "The only towns to survive were those standing away from the ore body. Almost every town on the Mesabi Range was either partially or completely moved at least once, Coleraine and Marble being the exceptions." ${ }^{53}$ In Chapter 4, I examine the contested nature of the negotiations that transpired with these moves, analyzing legal records resulting from the most notable displacement case involving the Oliver Iron Company and the town of Hibbing. I additionally illuminate other displacements, including the 
removal of a lake to make a mine, highlighting both the political power that the mining industry in Minnesota possessed, and the value placed on iron ore in comparison to the broader environment.

In her study of post-industrial landscapes, archaeologist and heritage specialist Anna Storm explores the iron mining town of Kiruna, Sweden, which is in the process of relocation. ${ }^{54}$ Kiruna is experiencing a similar displacement to what occurred in the Mesabi Range a century earlier, where the mining industry argues in economic terms that displacements are necessary inconveniences to enjoy continued economic benefits that come with mining. Additionally, the heritage discourse of Kiruna parallels that of the Mesabi Range, where Storm finds that the region's rich mining heritage is promoted while the diverse interests of the Sami community, such as reindeer herding, are downplayed and obfuscated. ${ }^{55}$ This discourse perpetuates a counterfactual narrative of community subservience to a paternal mining industry, which I show in Chapters 4 and 5 were not historically accurate in the Mesabi Range, yet they have remained prevalent in mining communities for more than a century.

While the technologies used in mining low-grade ores dug up and reworked many of the landscape features characteristics of more historical mining activities, remediation and heritage efforts have also obfuscated much of the Mesabi Range's mining legacy. In Chapters 2 and 4, I find that much of the built environment of the Mesabi Range has been transformed due to successive mining efforts and abandonment, as well as reclamation and revitalization policies. In terms of the built environment, I find that less than 15\% of beneficiation plants are still visible on the Mesabi Range - owing to both abandonment and a concerted effort by the state to remove mine buildings. Historian and landscape scholar Elizabeth Raymond argues that the Mesabi "incorporates a number of disparate visions of what a 
mining landscape is and means. Technology works simultaneously to create this landscape and to obliterate it in the interests of a more natural version." ${ }^{56}$ Adding to Raymond's study, in Chapter 4, I analyze the efforts by the Minnesota DNR to re-vegetate, re-contour, and rehabilitate much of the post-industrial landscape in an attempt to naturalize the region to attract recreational tourism.

Industrial archaeologists Robert Gordon and Patrick Malone see industrial archaeology as offering new avenues to explore both historical technological failure and lasting environmental impacts within mining landscapes. Gordon and Malone argue that through the use of "modern analytical and diagnostic techniques" industrial archaeologists might illuminate "the causes of industrial failure that were unrecorded, covered up, or not known by participants. The answers may lie in broken parts, chemical residues, slag heaps, or the shale particles found around the foundation of an amalgamator." ${ }^{37} \mathrm{I}$ analyze the broad mining landscape in Chapters 2, 4 and 5 and use industrial archaeological techniques to highlight the many lasting environmental legacies, such as transportation networks, tailings, and structural footprints still embedded in the Mesabi Range.

Each chapter in this dissertation explores the tangible heritage of the Mesabi Range through a landscape perspective, because landscape analysis allows a comprehensive and evocative overview of a region's past. The materiality of landscape features provides a useful grounding for the discourses found in both heritage studies and historical narratives. In these chapters I read the mining landscape and highlight both the function of technological systems, as well as the complex social systems and political decisions that developed within the mining landscape. This process reveals the extent to which the landscape retains these environmental legacies, showing how the 
remains of industry continue to interact with the environment long after the mines closed.

In his essay on post-industrial landscapes, archaeologist Norbert Tempel also sees the potential of melding the narratives of environmental history, the history of technology, and industrial archaeology, into macro-histories that reveal more than just the sitespecific environmental impacts produced from a specific industry, but also the lasting landscape-scale transformations wrought from industrialization. Tempel argues, "Industrial heritage...gives us the chance to reflect on the use, or perhaps abuse, of our resources. It allows us to reflect upon the pollution and destruction of our environment, social and economic changes, our changing perception of technology and the debates concerning priorities in our society." ${ }^{8}$ In Chapters 2 and 3, I add to Tempel's argument by showing that historical datasets can be used to better inform current environmental concerns, such as impaired waters and the identification of historic waste management technologies that might fail due to climate change.

The importance of recognizing and interpreting mine waste on the landscape is a predominant theme that runs throughout this dissertation. Archaeologist Donald Hardesty and historian Fred Quivik have both discussed the cultural value of waste, with Hardesty arguing that waste can convey a message that shows "the impact of industrial technologies upon workplaces, communities, and landscapes," while Quivik argues, that the technologies used to confine waste depict the "contested terrain" that occurred amongst communities, the mining industry and the state over waste disposal. ${ }^{59}$ However, both Hardesty and Quivik's focus are placed primarily on the value of preserving these waste features within the landscape, an effective heritage strategy, but one that I believe has dominated the ontological approach of the industrial heritage profession. In Chapters 2, 3, and 5, 
I argue that mine waste contains immense cultural value, whether we preserve it or not, and that recognition and interpretation should be the primary goals when confronting mine waste. Additionally, in Chapter 2, I provide a methodology that heritage professionals can use to identify, recognize and interpret historical mine waste across post-industrial landscapes. I argue that for industrial heritage professionals to stay relevant, they must look beyond preservation and tourism, and address contemporary concerns, which can be accomplished by first recognizing the cultural significance of waste, and next, interpreting the meaning of waste to broader publics.

The importance of mining's legacy effects, such as tailings, toxicity, and water impairments, have been a focus of research from Arn Keeling and John Sandlos who explore the persistence of what they call "zombie mines" and industrial waste. ${ }^{60}$ Sandlos and Keeling study the social and environmental impacts of historical mining in the Canadian north, exploring how indigenous communities often adopt the costs of abandoned mines. ${ }^{61}$ My work in Chapters 4 and 5 also looks at mining's legacy effects, exploring how communities in the Mesabi Range must bear the environmental costs of mining decades after the mines and mining companies ceased to exist. Investigative journalist John Hillkirk, has also examined the legacy effects produced from former lead smelters located near population centers. ${ }^{62}$ In his Ghost Factories project, Hillkirk notes that a large number of former industrial factories had been forgotten, and were never subject to hazardous material cleanup or any government assessments to determine health risks for individuals who lived nearby, which resulted in elevated levels of lead among community members. In Chapters 2 and 5, I highlight how a mine is more than a hole in the ground, through mapping the technological systems and waste footprints produced from low-grade ores. By mapping the locations of 
more than 100 beneficiations plants across the Lake Superior district, I've provided an historical spatial context regarding the environmental demands and impacts that these plants produced, such as water consumption and waste production.

\section{Dissertation chapters}

This dissertation is a collection of four submitted peer-reviewed journal articles, rather than a traditional monograph. At Michigan Tech, students who take the article approach are required to provide an overview chapter that introduces the collection, describes how the multiple pieces fit together to address an overarching research and/or policy goal, explains how the collection fits within the larger body of scholarship, summarizes the findings, describes the methods, and clarifies the student's role in co-authored papers.

\section{Chapter 2 (Article 1): John Baeten, Nancy Langston, Don} Lafreniere, “A geospatial approach to uncovering the hidden waste footprint of Lake Superior's Mesabi Iron Range,” The Extractive Industries and Society, Vol. 3, No. 4 (Nov., 2016)

\section{1-1045.}

The first paper (published) examines the technological changes and political decisions that allowed for the expansion of iron mining across the Lake Superior iron district. I ask what technological and political changes enabled a shift in 1910 to the mining of much lowergrade washable ores in the Mesabi Range? Lastly, what were the technological and political changes that enabled a shift in 1947 to taconite mining?

These technological transitions resulted in spatial shifts in terms of ore production and waste deposition. Prior to the mining of low-grade ores, the waste footprint from iron ore mining was generally 
confined to the mines themselves. As low-grade iron ore mining boomed, a new form of mine waste called tailings, were produced at beneficiation plants, which were often located far from the mines themselves. This new form of waste was first deposited into lakes, and later into constructed tailings basins.

This chapter uses an historical GIS to map the spatial extent of mining and ore processing across the Lake Superior iron district, and uncover the historical landscape of waste produced from iron ore beneficiation in the Mesabi Range. This chapter suggests a methodology that can be applied to other historic mining and industrial landscapes to identify the location, producer, and content of historic wastescapes.

Chapter 3 (Article 2): John Baeten, Nancy Langston, Don Lafreniere, “A Spatial Evaluation of Historic Iron Mining Impacts on Current Impaired Waters in Lake Superior's Mesabi Range," submitted to Ambio: A Journal of the Human

\section{Environment April 2017.}

The second article in the dissertation analyzes how technological shifts in mining produced varying water quality legacies in the Mesabi Range. Are there spatial correlations between current impaired waters in the Mesabi Range and the locations of historic iron ore mining, processing and waste deposition?

This article also uses an historical GIS to analyze how the locations of mines and processing plants compare with current impaired waters in the Mesabi Range. This article uses subwatershed boundaries within the immediate extent of the Mesabi Range to ask if there are correlations between current impaired waters and historic mining sites or ore processing sites. 
This article first maps the historical locations and quantities of iron ore mining and processing, including water consumption and tailings production. Next, this article identifies and maps the locations of impaired lakes located within the subwatershed boundary. Using this data, this article analyzes if lakes that experienced a higher degree of mining also have been scored as impaired. This article also suggests a methodology, the use of historic data sets to inform current policy, which can be applied to other historic mining landscapes to analyze the legacy effects of mining on current watershed health.

Chapter 4 (Article 3): John Baeten, “Contested Landscapes of Displacement: Oliver Iron and the Hibbing Mining District," Change Over Time: An International Journal of Conservation and the Built Environment (in press, forthcoming Fall 2017).

The third article in my dissertation examines the social responses to the development of open-pit and low-grade iron ore mining in the Mesabi Range, specifically in how communities, the mining industry and the state negotiated the transforming physical and economic landscape, and how these negotiations have been memorialized or forgotten in a heritage context.

As open-pit iron mining in Minnesota grew during the 1900s, these growing pits began to physically displace many communities. The mining industry argued that these displacements were just trivial inconveniences that came with the many economic benefits that mining brought to the area. Although the iron industry was the major employer in the region, archival records show that many of these communities contested these displacements.

As mining in the Mesabi transitioned to taconite during the 1970s, many of the former washable ore and direct shipping ore 
mines closed, and state agencies began to reclaim and reimagine the Mesabi's post-mining landscape as a recreational attraction. This process involved the removal of mine buildings, the revegetation of mine waste, and the stocking of fish into former mines. In an effort to rejuvenate the economy, these efforts focused on promoting nostalgia rather, and in doing so, have created a distorted collective memory of the region's dynamic and contested past.

\section{Chapter 5 (Article 4): John Baeten, “Negotiating Mobile Mine Waste: Environmental Legacies of Low-Grade Iron Ore Mining in Minnesota's Mesabi Range," submitted to Environmental History June, 2017.}

The fourth article in my dissertation explores how communities negotiated the new environmental challenges that arose from the mining and processing of low-grade iron ores. The introduction of beneficiation technology in the Mesabi Range in 1910 produced a new form of mine waste in the Mesabi, tailings, which often migrated far from where they were originally dumped. This technological change brought the visible environmental impacts from mining into residential communities, where the public, mining companies and the State weighed the environmental costs of mining with its economic benefits.

This article analyzes the legal decisions and landscape changes that resulted from these negotiations. Although the majority of structures and machines emblematic of an ore processing landscape are no longer visible in the Mesabi Range, the widespread environmental legacies that they produced remain embedded on the landscape. This article asks how the environmental legacies of lowgrade iron ore mining and processing have been remembered or forgotten in the Mesabi Range. 


\section{Methods}

In this dissertation, I use a mixed methods approach, combining archival sources, material from historical mining trade journals, the analysis of historical and modern aerial imagery, examination of remote sensing data, such as LiDAR, GIS analysis of large existing data sets on impaired waters, and on the ground field-based research.

Chapters 2 and 3 include a detailed overview of the specific methodologies used to answer each of these chapter's research questions. Chapters 4 and 5 are more traditional history articles, and do not include a methods section. For both of these chapters I used archival data, geospatial analysis, historic aerial imagery and LiDAR imagery, and field-based analysis to answer the overall research objective.

A primary objective of this research was spatial in nature, as I wanted to understand how historic mining activity was retained on the post-mining landscape. This reconstruction follows a similar method employed by historical geographers such as Anne Knowles study of the $19^{\text {th }}$ Century iron mining landscape, Geoff Cunfer's examination into the causes of the dust bowl, and Don Lafreniere and Jason Gilliland's historical reconstruction of the industrial city. ${ }^{63}$ I was also inspired by the ghost factories project undertaken by a team of journalists that sought to map the locations of historic lead smelters in the United States. ${ }^{64}$ Since mining landscapes are so inherently hybrid, I wanted to understand not just the extent of industrial mining across the landscape, but also the extent of industrial loss. What environmental legacies from iron mining remain on the landscape? Did different mining technologies produce different environmental legacies? Are these legacies discernable from each other?

To answer these questions I began by producing an Historical Geographic Information System (HGIS) that started with an inventory 
of the historical mining landscape. In building this dataset, I wanted to identify the extent of mining across the Lake Superior iron district, understand how different mining technologies produced different environmental demands, identify which mines were producing lowgrade ores, locate the extent of beneficiation plants across the district, tie the low-grade ore mines to the plants that processed their ores, and finally understand how beneficiation plants compared in terms of water consumption and waste production.

The process of building the HGIS began by identifying the extent of mines across the Lake Superior iron district - a process that was aided by existing geospatial datasets managed by the United States Geological Survey (USGS). While these datasets include the names and spatial coordinates for the mines, these data did not include any quantifiable metric to understand how mine $\mathrm{X}$ compared to mine $\mathrm{Y}$ in terms of their environmental demands. To address this concern, I looked to historic trade journals, such as the Iron Trade Review, the Engineering and Mining Journal, and Skillings' Mining Review, and entered annual ore shipments that were reported from each mine in the district from 1897-2012. This HGIS now consisted of the names and spatial coordinates for the mines in the district, and quantifiable data for each year a mine produced iron ore.

Next, to understand how low-grade iron ore mines compared to high-grade iron ore mines I created an inventory of iron ore beneficiation plants across the district. Unlike the mines dataset that was managed by the USGS, no government agency has tracked the location of historic ore processing sites, including stamp mills, smelters, and iron ore beneficiation plants. To produce an historic inventory of beneficiation plants, I surveyed archival materials, such as company reports, historic maps and historic aerial imagery, as well as examined modern aerial imagery and LiDAR data, in an effort to pin 
point where the facilities were historically located. Once this beneficiation plant dataset was complete, I tied the mines that were producing low-grade ores to the plants they were sending their ore to be processed. This was accomplished through reexamining much of the archival sources.

The HGIS now consisted of the mine production data, as well as the locations of beneficiation plants, and a link between individual low-grade iron ore mines and the processing plants to which they were shipping ore. To ascertain how each plant differed in terms of water consumption and waste production, I again relied on archival materials, including company records and reports, and from this material, I generated production ratios based on averages from both washable ore plants and taconite plants. These ratios were reported as: gallons of water: tons of ore processed; tons of tailings: tons of ore processed - which were added to the HGIS and values were generated based on the quantity of ore shipped to each processing plant.

Now, the HGIS contained the spatial extent of mines and processing plants across the Lake Superior iron district, as well as quantifiable data that shows how different mining technologies produced varying environmental demands across both space and time. Using this HGIS I was able to produce visualizations such as timeseries animations, and choropleth and dot-density maps to highlight patterns that emerged across the Lake Superior iron district as mining technologies shifted from high-grade to low-grade ores. Overlaying these historical datasets with current environmental data, such as impaired waters datasets, I was able to compare deep relationships with historic industrial activity and current environmental quality.

I also wished to understand the extent and quantity of the mine waste produced from mining in the Mesabi Range. To accomplish this I digitized waste footprints found on topographic maps (1983 series), 
as well as what I could visually see on modern aerial imagery provided through the ESRI ArcGIS platform. This process entailed digitizing polygons around existing waste features, such as tailings ponds and waste rock piles, as well as digitizing the extent of open-pit scars. This dataset underrepresents the extent of mine waste in the Mesabi Range, as I was unable to digitize the millions of tons of tailings dumped directly into lakes. However, this waste dataset shows not just the changing locations of mine waste in the Mesabi Range, it shows the persistence of waste on the landscape.

\section{Broader Research Project}

This work was supported by the National Science Foundation (Grant \#R56645, Toxic Mobilizations in Iron Mining Contamination), in which I served as a graduate research assistant. This project aimed to use an envirotechnical approach to understand the interconnection between historic iron mining and current environmental concerns. My role in the project has been multifaceted, including: identifying and collecting production data on iron ore mining from historic trade journals; locating iron ore beneficiation plants from historic maps and aerial imagery; creating an historical geographic information system that included the ore production data, and beneficiation data regarding tailings production and water consumption; identifying and digitizing the current extent of mine waste and open-pit scarring on the Mesabi Range; analyzing the spatial correlations between historic mine and ore processing sites and current impaired waters in Minnesota; and analyzing whether or not the environmental legacies from iron mining have been memorialized by local heritage organizations.

I co-authored Chapters 2 and 3 with Nancy Langston and Don Lafreniere. I functioned as the first author for both of these chapters 
and was responsible for the majority of the data collection and spatial analysis, literature reviews, production of figures and maps, and the discussion of results. In Chapter 2, Lafreniere wrote the section on historical GIS within the literature review, and in Chapter 3, Langston produced the statistical analysis for the mean proportion of impaired lakes with different types of mining activity. 


\section{References:}

1 “The Iron Ore Dilemma," Fortune, December 1945.

${ }^{2}$ Stuart Harrison, "Where Is the Iron Ore Coming From?," Financial Analysts Journal 9, no. 3 (June 1953).

${ }^{3}$ Harlan Hatcher, A Century of Iron and Men (Indianapolis: The BobbsMerrill Company, 1950).

${ }^{4}$ Terry S. Reynolds and Virginia P. Dawson, Iron Will: Cleveland-Cliffs and the Mining of Iron Ore, 1847-2006 (Detroit: Wayne State University, 2011) 64-66.

${ }^{5}$ Reynolds and Dawson, Iron Will.

${ }^{6}$ Hatcher, A Century of Iron and Men, 132-133.

${ }^{7}$ Reynolds and Dawson, Iron Will, 60-61.

${ }^{8}$ David A. Walker, Iron Frontier: The Discovery and Early Development of Minnesota's Three Ranges (St. Paul, MN: Minnesota Historical Society, 1979).

${ }^{9}$ John Baeten, Nancy Langston, and Don Lafreniere, “A Geospatial Approach to Uncovering the Hidden Waste Footprint of Lake Superior's Mesabi Iron Range," The Extractive Industries and Society, Vol. 3, Issue 4, (November, 2016).

${ }^{10}$ Paul de Kruif, Seven Iron Men: The Merritts and the Discovery of the Mesabi (Minneapolis: University of Minnesota Press, 1929); Marvin G. Lamppa, Minnesota's Iron Country: Rich Ore, Rich Lives (Duluth: Lake Superior Port Cities, 2004); Thomas Bastow, This Vast Pollution: United States of America V. Reserve Mining Co. (Washington D.C.: Green Field Books, 1986); Jeffery T. Manuel, Taconite Dreams: The Struggle to Sustain Mining on Minnesota's Iron Range (Minneapolis: University of Minnesota Press, 2015).

${ }^{11}$ Duane A. Smith, Mining America: the Industry and the Environment, 1800-1980 (Niwot: University Press of Colorado, 1993) 36. 
${ }^{12}$ Hatcher, A Century of Iron and Men, 277.

${ }^{13}$ T.B. Counselman, "Beneficiating Minnesota Iron Ores", in Mining and Metallurgy (August, 1941) 405-406.

${ }^{14}$ Paul H. Landis, "Community and Neighborhood: The Life Cycle of the Iron Mining Town", in Social Forces, Vol. 13, No. 02 (Dec., 1934: 245256) 246.

${ }^{15}$ Manuel, Taconite Dreams.

${ }^{16}$ To categorize this, I surveyed interpretive markers along the Mesabi Trail, visited local heritage sites, such as the Minnesota Discovery Center and numerous mine-viewing areas, conducted a driving tour of the region, and surveyed literatures produced by the IRRRB and MNDNR as part of their re-visioning of the Mesabi Range.

${ }^{17}$ Arthur F. Taggart, Handbook of Ore Dressing (New York: John Wiley \& Sons, 1927) 2.

${ }^{18}$ Reynolds and Dawson, Iron Will; Manuel, Taconite Dreams; Nancy Langston, Sustaining Lake Superior: An Extraordinary Lake in a Changing World (New Haven: Yale University Press, 2017).

${ }^{19}$ Jessica Van Horssen, A Town Called Asbestos: Environmental Contamination, Health, and Resilience in a Resource Community (Vancouver: University of British Columbia Press, 2016). ${ }^{20}$ John R. Owen and Deanna Kemp, "Mining-Induced Displacement and Resettlement: A Critical Approach,” Journal of Cleaner Production 87 (2014)

${ }^{21}$ David Robertson, Hard as the Rock Itself: Place and Identity in the American Mining Town (Boulder: University Press of Colorado, 2006) 6. ${ }^{22}$ Richard Francaviglia, Hard Places: Reading the Landscape of America's Historic Mining Districts (Iowa City: University of Iowa Press, 1991) 129-130. 
${ }^{23}$ Francaviglia, Hard Places, 134-135.

${ }^{24}$ Thomas Hughes, Networks of Power: Electrification in Western Society, 1880-1930 (Baltimore: John Hopkins University Press, 1983). ${ }^{25}$ There are many other social factors involved, such as global markets, war, and the development of new technological systems such as open-pit mining, which can fuel further momentum into reworking the historic mining landscape.

${ }^{26}$ Clark C. Spence, Mining Engineers and the American West: The Lace Boot Brigade, 1849-1933 (New Haven: Yale University Press, 1970): Chapter 3.

${ }^{27}$ Kathryn Morse, The Nature of Gold: An Environmental History of the Klondike Gold Rush (Seattle: University of Washington Press, 2003); Thomas Andrews, Killing for Coal: America's Deadliest Labor War (Cambridge: Harvard University Press, 2008); Fredric Quivik, Smoke and Tailings: An Environmental History of Copper Smelting Technologies in Montana, 1880-1930 (Ph.D. dissertation: University of Pennsylvania, 1998); Timothy LeCain, Mass Destruction: The Men and Giant Mines that Wired America and Scared the Planet (New Brunswick: Rutgers University Press, 2009); and Kent Curtis, Gambling on Ore: The Nature of Metal Mining in the United States, 1860-1910 (Boulder: University of Colorado Press, 2013).

${ }^{28}$ Sara Pritchard and Thomas Zeller, "The Nature of Industrialization", in The Illusory Boundary: Environment and Technology in History (Charlottesville: University of Virginia Press, 2010) 75.

${ }^{29}$ LeCain, Mass Destruction.

${ }^{30}$ LeCain, Mass Destruction, 132-133.

${ }^{31}$ LeCain, Mass Destruction, 39. 
${ }^{32}$ Craig E. Colten, "Waste and Pollution: Changing Views and Environmental Consequences", in The Illusory Boundary: Environment and Technology in History, 184-185.

${ }^{33}$ Joel A. Tarr, The Search for the Ultimate Sink: Urban Pollution in Historical Perspective (Akron: University of Akron Press, 1996). ${ }^{34}$ The majority of ores removed from the Mesabi Range were iron oxide ores, in contrast to sulfide ores. This creates an assumption that the only waste material being produced from these mining operations are overburden, silica, and granite. Furthermore, the processing of iron ores from the Lake Superior basin did not require any form of leaching, which hints at a nonchemical extraction process. Geological Survey of Sweden, Mines and Environmental Impact, available at: $<$ https://www.sgu.se/en/mineral-resources/mines-and-environmentalimpact/>; Minnesota Center for Environmental Advocacy: Conservation Minnesota Friends of the Boundary Waters Wilderness, $A$ Mining Truth Report, available at: < http://www.miningtruth.org/faqsulfide-mining-minnesota-truth-report.pdf>; see also Langston, Sustaining Lake Superior, for an overview of the mining industry's arguments of the non-toxic nature of the tailings produced at Silver Bay, as well as the sulfide-laden overburden uncovered at the Dunka Pit mine.

${ }^{35}$ Langston, Sustaining Lake Superior.

${ }^{36}$ John Thistle and Nancy Langston, "Entangled histories: Iron ore mining in Canada and the United States", Extractive Industries and Society, Vol. 3, Issue. 2 (April, 2016) 269-277.

${ }^{37}$ Wolfgang Ebert, "Industrial heritage tourism", Industrial Heritage Retooled: The TICCIH guide to Industrial Heritage Conservation, James Douet, ed. (Lancaster: TICCIH, 2012) 
${ }^{38}$ Heritage sites that account for conflicts between labor and management in the United States, include: American Textile History Museum; Boott Cotton Mills Museum; Lowell National Historic Park; and Rivers of Steel National Heritage Area.

${ }^{39}$ Donald Hardesty, "Issues in Preserving Toxic Wastes as Heritage Sites”, The Public Historian, Vol. 23, No. 2 (Spring, 2001); Fredric Quivik, "The Historical Significance of Tailings and Slag: Industrial Waste as Cultural Resource," IA: The Journal of the Society for Industrial Archaeology, Vol. 33, No. 2 (2007).

${ }^{40}$ Francaviglia, Hard Places; Peter Goin and Elizabeth Raymond, "Mining's Legacies in the Mesabi Iron Range", in Technologies of Landscape: From Reaping to Recycling, David Nye, ed. (Amherst: University of Massachusetts Press, 1999); Peter Goin and Elizabeth Raymond, Changing Mines in America (Santa Fe: The Center for American Places, 2003).

${ }^{41}$ Walker, Iron Frontier, Richard Hudelson and Carl Ross, By the Ore Docks: A Working People's History of Duluth (Minneapolis: University of Minnesota Press, 2006); Arnold R. Alanen, Morgan Park: Duluth, U.S. Steel, and the Forging of a Company Town (Minneapolis: University of Minnesota Press, 2007); Manuel, Taconite Dreams.

${ }^{42}$ Laurajane Smith, Uses of Heritage (London: Routledge, 2006) 4.

${ }^{43}$ Manuel, Taconite Dreams, 164-165, 177-193.

${ }^{44}$ Manuel, Taconite Dreams, 182.

${ }^{45}$ Smith, Uses of Heritage; Laurajane Smith and Emma Waterton, Heritage, Communities, and Archaeology (London: Duckworth, 2009); Jon Price, "Interpreting Industrial Heritage", in Heritage Interpretation, Alison Hems and Marion Blockley, eds. (London and New York: Routledge, 2006); Alice Mah, Industrial Ruination, Community, and Place: Landscapes and Legacies of Urban Decline (Toronto: University 
of Toronto Press, 2012); Rodney Harrison, Heritage: Critical Approaches (London: Routledge, 2013)

${ }^{46}$ Mah, Industrial Ruination, 14.

${ }^{47}$ Harrison, Heritage: Critical Approaches, 14.

${ }^{48}$ These are: the Mount Polley mine disaster in British Columbia; the Gold King Mine disaster in Colorado; and the Bento Rodrigues mine disaster in Brazil.

${ }^{49}$ Mikkel Bille, Frida Hastrup, Tim Flohr Soerensen (eds.), An Anthropology of Absence: Materializations of Transcendence and Loss (New York: Springer-Verlag, 2010) 4, 11.

${ }^{50}$ Lynn Meskell, "An Anthropology of Absence: Commentary", An Anthropology of Absence: Materializations of Transcendence and Loss, Mikkel Bille, Frida Hastrup, Tim Flohr Soerensen (eds.), (New York, Soringer-Verlag, 2010) 207.

${ }^{51}$ Emma Waterton and Steve Watson, "Heritage as a Focus of Research: Past, Present and New Directions", in The Palgrave Handbook of Contemporary Heritage Research, Emma Waterton \& Steve Watson, eds. (London: Palgrave Macmillan, 2015) 11.

${ }^{52}$ Kenneth E. Foote, Shadowed Ground: America's Landscapes of Violence and Tragedy, Revised and Updated (Austin: University of Texas Press, 2003).

${ }^{53}$ Walter L. Thurman, Waste Dumps of the Mesabi Iron Range: Heritage or Blight? unpublished M.A. thesis, (St. Cloud: St. Cloud State University, 1992), 9.

${ }^{54}$ Andres Lundgren, "Kiruna - A City in Constant Transformation", in Post-Mining Landscape: IBA Conference Documentation (Berlin: Jovis, 2010) 138-143; Anna Storm, Post-Industrial Landscape Scars (New York: Palgrave Macmillan, 2014).

${ }^{55}$ Storm, Post-Industrial Landscape Scars, 38-39. 
${ }^{56}$ Goin and Raymond, Changing Mines in America, 275.

${ }^{57}$ Robert B. Gordon and Patrick M. Malone, The Texture of Industry: An Archaeological View of the Industrialization of North America (Oxford: Oxford University Press, 1994): 209-210.

${ }^{58}$ Norbert Tempel, "Post-Industrial Landscapes" in Industrial Heritage Re-Tooled: The TICCIH Guide to Industrial Heritage Conservation, James Douet, ed. (Lancaster: Carnegie Publishing House, 2012): 142.

${ }^{59}$ Hardesty, Issues in Preserving Toxic Wastes, 20; Quivik, The Historical Significance of Tailings and Slag, 49.

${ }^{60}$ John Sandlos and Arn Keeling, "Zombie Mine and the (Over)burden of History", in The Solutions Journal, Vol. 4, Issue 3 (June 2013) 82. ${ }^{61}$ Arn Keeling and John Sandlos, Mining and Communities in Northern Canada: History, Politics, and Memory (Calgary: University of Calgary Press, 2015) 379. ${ }^{62}$ John Hillkirk, et al., "Ghost Factories: Poison in the Ground”, in USA Today, <http://content.usatoday.com/news/nation/smelting-leadcontamination $>(2012)$

${ }^{63}$ Geoff Cunfer, "Scaling the Dust Bowl," in Placing History: How Maps, Spatial Data, and GIS are Changing Historical Scholarship, Anne Kelly Knowles, ed. (Redlands: Calif.: ESRI Press, 2008) 95-121; Anne Kelly Knowles, Mastering Iron: The Struggle to Modernize an American Industry, 1800-1868 (Chicago: University of Chicago Press, 2012); Don Lafreniere and Jason Gilliland, "All the World's a Stage: A GIS Framework for Recreating Personal Time-Space from Qualitative and Quantitative Sources," in Transactions in GIS, Vol. 19, No. 2 (2015) 225-246.

${ }^{64}$ Hillkirk, Ghost Factories; and Alison Young \& Peter Eisler, "Ghost Factories: Poison in the Ground," USA Today (April 25, 2012). 


\title{
Chapter 2: A Geospatial Approach to Uncovering the Hidden Waste Footprint of Lake Superior's Mesabi Iron Range $^{1}$
}

\begin{abstract}
:
For decades, the Lake Superior Iron District produced a significant majority of the world's iron used in steel production. Chief among these was the Mesabi Range of northern Minnesota, a vast deposit of hematite and magnetic taconite ores stretching for over 100 miles in length. Iron ore mining in the Mesabi Range involved three major phases: direct shipping ores (1847-1970s), washable ores (19071980s), and taconite (1947-current). Each phase of iron mining used different technologies to extract and process ore. Producing all of this iron yielded a vast landscape of mine waste. This paper uses a historical GIS to illuminate the spatial extent of mining across the Lake Superior Iron District, to locate where low-grade ore processing took place, and to identify how and where waste was produced. Our analysis shows that the technological shift to low-grade ore mining placed new demands on the environment, primarily around processing plants. Direct shipping ore mines produced less mine waste than lowgrade ore mines, and this waste was confined to the immediate vicinity of mines themselves. Low-grade ore processing, in contrast, created more dispersed waste landscapes as tailings mobilized from the mines themselves into waterbodies and human communities.

${ }^{1}$ This chapter is in print with The Extractive Industries and Society, as: John Baeten, Nancy Langston, Don Lafreniere, "A geospatial approach to uncovering the hidden waste footprint of Lake Superior's Mesabi Iron Range", The Extractive Industries and Society, Vol. 3, Issue 4 (November 2016) 1031-1045.
\end{abstract}




\section{Introduction}

Worldwide, the storage and handling of tailings has become a major environmental issue for mining. The scale of tailings production is immense, since low-grade ore extraction creates significant volumes of waste for each quantity of merchantable product produced. Monitoring the environmental legacies of tailings requires the ability to map where the tailings were produced and deposited over time, which is often surprisingly difficult given the limitations of historical records. This paper uses spatial history techniques, though the creation of a historical GIS, to uncover the hidden waste footprint of iron mining across the Mesabi Range. We integrate a variety of sources to map the iron ore extracted from the Mesabi Range, their processing sites, and their waste footprints. We ask: how did iron mining footprints change over time in the Mesabi Range, and how did changing technologies affect the waste footprint over time and space? This paper is the first part of a larger project that will explore the ways that these historic waste landscapes may influence current environmental factors such as water quality and water quantity.

For the past 120 years, the Lake Superior Iron District has been the top producer of iron ore in the United States (Figure 1). Here, iron mining has produced an enormous volume of waste in the form of gangue (waste rock) and tailings (finely ground materials left after processing of lower-grade iron ore). Much of this waste is now difficult to see from the ground, because it is concealed beneath lakes that filled abandoned mines and forests that have begun to grow over some waste piles. Nevertheless, even when the waste is hard to see, it may continue to affect the environment, particularly when it becomes mobilized into water and air.

North American economic expansion after the Civil War 
required steel, which in turn required abundant sources of iron ore. The iron ranges of Minnesota, Wisconsin, and Michigan--collectively known as the Lake Superior District (Figure 2.1)--were the continent's most important source of iron (“The Iron Ore Dilemma," 1945, 129). By 1890 , more than $50 \%$ of the iron ore used by the American iron and steel industry came from the Lake Superior District. Half of a century later, by the end of World War 2, the region supplied 85\% of the nation's iron ore (Harrison, 1953). After World War II, much of the Lake Superior Iron District's production shifted to the Mesabi Range of Minnesota. By 1980, 80\% of the iron ore produced in the Lake Superior District came from this one range.

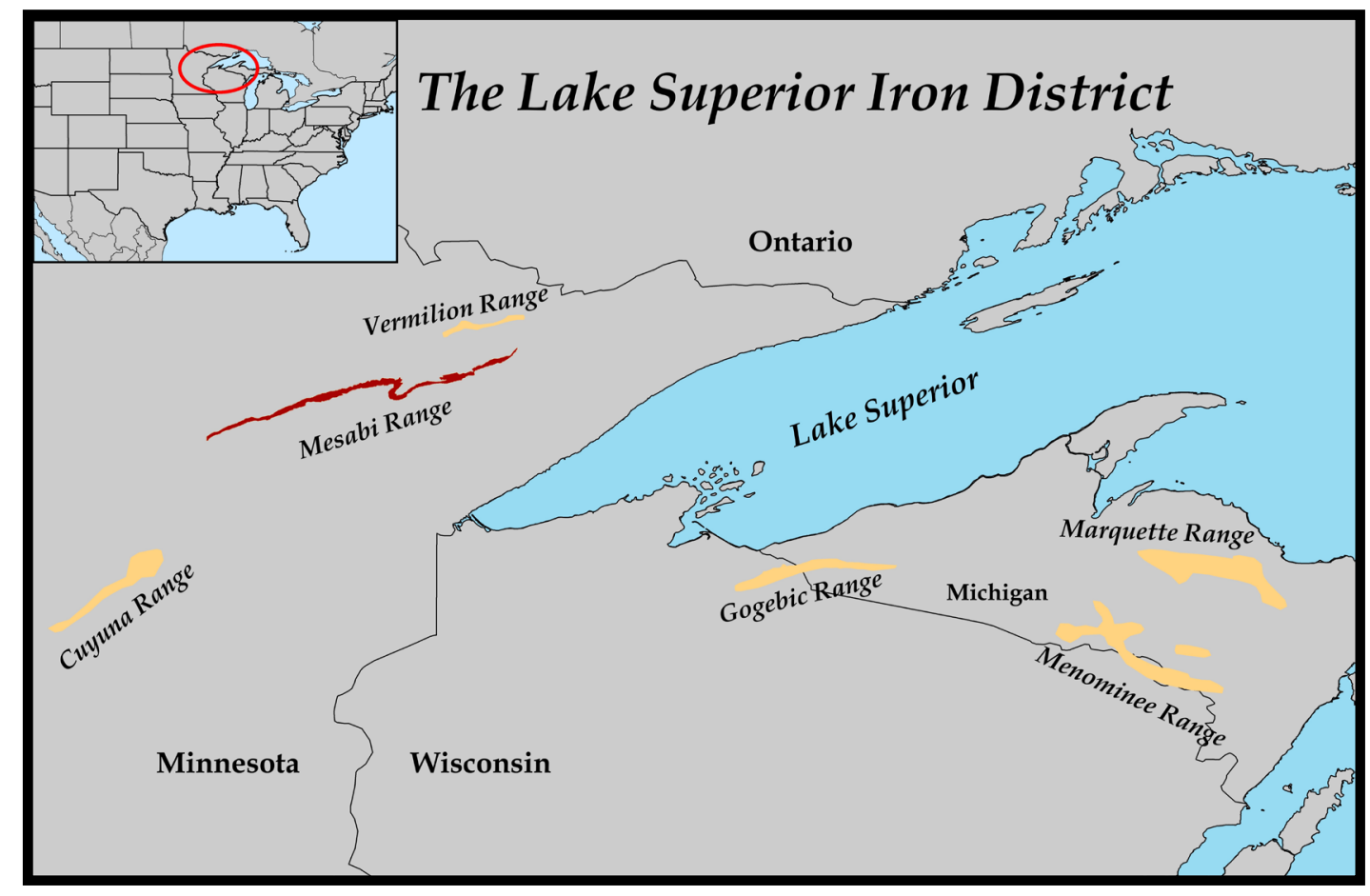

Figure 2.1: The Lake Superior Iron District

Iron mining in the Lake Superior Iron District involved three major phases: direct shipping ores (1847-1970s); washable ores (19101980s); and taconite (1947-Today). This paper asks: what new forms of mine waste resulted from the technological shift to lower-grade iron 
ore mining in the Lake Superior District? What spatial shifts in mining production and waste production occurred with the development of lower-grade iron mining? Where were tailings produced and deposited? Recent scholarship focused on extractive industries has illuminated the interdependence of technology and the environment, an approach named "envirotech" that lies at the intersection of environmental history and history of technology (Reuss and Cutcliffe, 2010). Envirotech research in mining highlights the historical intermingling of nature and culture that has effectively shaped the mining landscape (Andrews, 2008; Curtis, 2013; LeCain, 2009; Morse, 2003; Reuss and Cutcliffe, 2010). These studies rely on analytical approaches such as actor-network theory and systems theory to understand how "complex bundles of human values, institutions, and technology" such as mining systems developed and functioned (Finger, 2013, p. 152). People acting as so-called "systems builders"(the innovators who work to add momentum to a technological system), the material technology, and the environment itself all acted as factors in the shaping of the Mesabi mining landscape (Bijker et al., 1987; Hughes, 1983). In the Mesabi, systems builders included the geologists who explored the region during the 1850s, the numerous land-holding agencies that leased mineral rights to mining companies, and the scientists who constructed social networks with metallurgists in the American Southeast to bring lowgrade ore concentrating technologies to the Lake Superior District (Davis, 1964).

The material technologies that shaped the Mesabi include the rail lines, ore conveyors, washing plants, and tailings basins-all features that represent human expertise and knowledge. This expertise is seen in the professionalization and education of mining engineers and mine superintendents, as well as with the incorporation 
of chemists and metallurgists in the mining industry (Hovis and Mouat, 1996; Spence, 1970). Additionally, as more efficient technologies were introduced to a region, the abundance of redundant buildings, machines, and transportation systems within the mining landscape represents a changing production of knowledge. In the Mesabi Range, this changing production of knowledge occurred during the shifts from direct shipping ore, to washable ore, and to taconite, and these shifts had rippling effects on the larger environment of waste production.

The environmental components that shaped the Mesabi mining landscape include both the initial environmental context that enabled mining to boom, and the environmental consequences that flowed from mining. The ore formation (the Biwabik iron formation,) the region's abundance of timber, Lake Superior which allowed for shipping ore to markets, and the region's surface waters were among the environmental components necessary for profitable low-grade iron mining (Hatcher, 1950). Yet on their own, none of these environmental components made mining inevitable; each of them first had to be transformed by technology, labor, capital, and expertise. The ore body had to be explored and developed; the trees had to be logged and milled; the estuary at Duluth had to be shaped into a deep-sea port, and the surface waters had to be channeled and pumped to the processing plants.

Economic transformations helped enable these envirotech modifications of the Mesabi Range into the world's largest iron ore producer. Between 1896 and 1900, small American steel companies were replaced by large steel corporations that controlled not just steel mills, but also the iron mines that supplied those mills (Reynolds and Dawson 2011). Processing low-grade ores required extensive technological and financial investments in beneficiation, investments 
that large, vertically-integrated corporations were better able to afford. Yet state power was also involved in enabling these transformations. Federal involvement in the creation of a shipping and railroad infrastructure within the Great Lakes, starting with the 1855 construction of Sault St. Marie locks, enabled $19^{\text {th }}$ century expansion of the Lake Superior District (Bowlus 2010, Reynolds and Dawson 2011). In the 20th century, the shift to low-grade ores required government investments in infrastructure and new tax policies (Thistle and Langston 2016).

To date, most histories of iron mining in the Lake Superior District have focused on the development of the region as a hub for direct shipping ores (de Kruiff, 1929; Hatcher, 1950; Lampa, 2004; Reynolds and Dawson, 2011), or taconite mining (Bastow, 1986; Davis, 1964; Manuel, 2015). Washable ores have received considerably less attention. Similarly, few studies have explored the environmental impacts or waste impacts of iron mining in the region, focusing instead on business history of hematite (Reynolds and Dawson, 2011) or engineering demands of taconite (Manuel, 2015). Identifying, understanding, and managing mine wastes remains a pressing environmental challenge. Mining's environmental consequences include some waste products that are visible today, such as tailings ponds, mine-pit lakes, and gangue piles. But other transformations are obscured from our gaze: ground water pollution, asbestos contamination, and mercury mobilization. While many of the physical structures of iron mines such as rail lines, steam shovels, and shaft houses no longer remain on the landscape, their environmental footprints persist.

As evident in Arn Keeling and John Sandlos' ongoing research at the Giant Mine in the Northwest Territories, communities and public policy-makers must contend with the environmental legacies of 
abandoned industrial operations which continue to "exert some sort of malevolent effect during their afterlife" (Sandlos and Keeling, 2013, p.81; see also Keeling and Sandlos, 2015). In the Mesabi Range, the valueless waste products were deposited near the mines and concentrating plants, while the valuable ore and mining profits were exported out of the region. Although historical trade journals cover the technological processes employed to produce different forms of mine waste, where the waste is located, how much waste was produced, and what the waste consists of, have remained unstudied in the broader context of Lake Superior iron mining.

In recent years, an interdisciplinary mass of scholars has turned its attention to the use and potential of GIS and related geospatial sciences to uncover and explain patterns and processes of the past. Historical geographers and environmental historians have been grappling with how to best model and analyze historical landscapes, a challenge because of the need to create complex historical datasets from original archival data. Successful examples include Geoff Cunfer's reexamination of the causes of the dust bowl, Matthew Hatvany's modeling of salt marsh evolution in the St. Lawrence Estuary, Anne Kelly Knowles' reconstruction of the landscape of the early American iron industry, and Lafreniere and Gilliland's recreation of the built environment in the nineteenth century industrial city (Cunfer, 2008; Hatvany, 2014; Knowles, 2012; Lafreniere and Gilliland, 2015). We follow these methodological approaches developed in the blossoming discipline of Historical GIS (HGIS) and apply them to the recreation of the landscape of mine waste in Minnesota's Mesabi Range.

The Mesabi Range contains a large number of abandoned mines and processing plants, places where much of the physical remains of industrial activity have been removed, leaving opaque reminders of 
the region's intensive mining past. This study uses integrated techniques from historical geography, environmental history, and industrial archeology to uncover a hidden landscape of waste where the remains of industry continue to interact with the environment long after the mines and processing plants have closed.

\section{The Three Phases of Mine Waste}

\subsection{Direct shipping ore wastes}

Direct shipping ores were located throughout the Lake Superior Iron District and operated mainly between 1847 and1970. They were first mined in the Michigan iron ranges and then in Wisconsin and Minnesota. Direct shipping ores were primarily hematite, a mineral that contained the highest percentage of iron, ranging from 50 to $70 \%$ (Manuel, 2015). Direct shipping ores were extracted through selective mining processes, rather than through bulk mining. To maximize the efficiency of selective mining, engineers' goal was to handle the least amount of waste possible (Cummins and Given, 1973). The high percentage of iron in these hematite deposits meant that this ore did not require processing before it could be shipped. Rather, direct shipping ores could be shipped directly to smelters in the lower Great Lakes, where they could be processed into steel.

The waste footprint created from high-grade ore mining consisted of piles of overburden and "gangue," a form of waste rock. Overburden consists of the organic material that covers shallow ore deposits, removed by scraping the mine's surface. Gangue consists of the bedrock structures that surround underground veins, encountered when sinking a shaft and developing underground excavations (Young, 1932). To save on transportation costs, these wastes were typically located within less than a mile of each mine. Direct shipping ore 
mines did not produce tailings, the fine ground material left over after processing lower-grade ores. Because overburden and gangue are composed of material that was not finely ground or processed, these wastes were not particularly mobile. Unlike much of the tailings produced during lower-grade ore processing, poor rock and overburden have remained in place for decades as static features on the mining landscape of the Mesabi Range (Thurman, 1992).

\subsection{Washable ore wastes}

In the United States, fears over the depletion of high-grade mineral deposits became pronounced soon after World War 1. The mining industry responded with economic and technological changes that allowed the exploitation of increasingly low-grade ores. Companies came to rely on science, engineering and rationalization to turn large amounts of what had earlier been seen as waste into profits. As Logan Hovis and Jeremy Mouat argue in their study of North American copper mining, the redesigning of the North American mining system centered on the "adoption of higher-volume, nonselective methods that emphasized the quantity rather than the quality of ore brought to the surface"(Hovis and Mouat, 1996, pp. 434435).

North American engineers developed the first intensive lowgrade mining technologies to exploit the porphyry copper deposits of the American West. Porphyry copper ores, such as the ones found in Utah's Bingham Pit, contained close to 98\% waste. For these mines to be successful, engineers needed to deploy an extensive bulk-mining system that could efficiently extract vast tracks of ore, coupled with a concentrating technology that could elevate the finite percentage of copper up to a merchantable content (LeCain, 2009). LeCain argues that such low-grade mining technologies acted as mechanisms of 
"mass-destruction," because they were engineered to extract vast quantities of material indiscriminately and efficiently. In particular, open-pit mining technology allowed mining engineers to effectively rationalize and systematize a natural system so that "nature itself was a factory carved out of natural stone"(LeCain, 2009, pp. 132-133). Similarly, the washable ore and taconite mines found in the Mesabi Range owed their existence to an innovative enviro-technological system.

After World War 1, mining companies in the Lake Superior Iron District researched new technologies to convert less concentrated, lower-grade iron deposits into profitable ores, a process called beneficiation (Birkinbine, 1919, 19). In the US West, beneficiation included chemical methods, such as flotation units and cyanide leaching tanks, to concentrate low-grade nickel and copper ores (Hovis and Mouat, 1996; LeCain, 2009). In the Mesabi Range, however, beneficiation relied upon mechanical methods to concentrate iron content from washable ores (Manuel, 2015; Smith, 1993). The first beneficiation technology in the Lake Superior District focused on the washable ores located primarily in the western extent of the Mesabi Range (Counselman, 1941). Washable ores were largely composed of decomposed hematite mixed with loose sand, and typically contained between 30\% and 45\% iron ("Coleraine District, Mesabi Range," 1907). Because of the low percentage of iron ore and the high percentage of silica, washable ores required processing to separate the waste from the valuable ore before they could be shipped or sold.

Low-grade iron ore beneficiation occurred at beneficiation plants, facilities that required a great deal of water and therefore were typically located on water bodies located within three miles from the mine pits themselves. Lakes provided beneficiation plants with an ample supply of water that was introduced as the ore traveled across 
screens and classifiers, riffled tables, and through mechanisms that captured heavy material and released the lighter-fine material as tailings (Taggart, 1927). The high costs associated with constructing beneficiation plants meant that each mine did not have its own nearby beneficiation plant but instead sent their ore to plants, located from up to 5-miles from the mine. These beneficiation plants were called either "central milling plants" or "custom mills", as they were equipped to treat a variety of ores from an assortment of mines, such as the Coons-Pacific Concentrator in Eveleth, MN ("Coons-Pacific Iron Ore Treatment Plant,” 1953).

Beneficiation plants produced abundant quantities of tailings, a slurry of water and extremely finely-ground, silica-laden rock. Optimally, the tailings produced from processing washable ores accounted for only $30 \%$ of the total material extracted, and the concentrated ore carried an iron percentage of just over 50\% ("Work on the Mesabi Range is Extensive," 1906). But since the grade of washable ores varied by deposit, the amount of waste within each deposit could be higher, resulting in a greater production of tailings.

In the Mesabi Range, tailings were initially deposited directly into inland lakes within 1 mile of a beneficiation plant. These tailings were deposited into lakes through a system of launders (or concrete troughs), or were pumped to the lakes through pipes. Because beneficiation plants often operated in either 12 or 24 hour shifts, the flow of tailings exiting the facilities required a substantial sink so that wastes would not back up and slow production (Taggart, 1927). Washable ore mining matured in the 1930s, and mining companies relied on more advanced beneficiation methods, such as heavy-media separation and sink-float methods, to reclaim the fine values found within these low-grade ores and within many of the former tailings basins (Hubbard, 1948). As the mining of washable ores intensified, 
these tailings basins grew in size and in number ("Nashwauk...," 1958).

The production of tailings brought mine waste outside of the immediate mining landscape, extending the environmental footprint of mining some distance from the mines themselves ("By the Way," 1914). If deposited in a water body, tailings were finely ground enough so that they could migrate far from the locations they were laundered, ending up in water bodies downstream of the beneficiation plants that produced them. If deposited on land, some tailings were blown into the air and transported by air currents into nearby towns, which raised concerns among residents.

\subsection{Taconite Wastes}

During the Second World War, as iron exports intensified for wartime steel production, depletion fears grew in the Lake Superior district. Mining engineers developed a technology allowing exploitation of taconite, an abundant yet very low value iron ore in the Lake Superior Iron District. Taconites contains up to 30\% iron (Manuel, 2015). Because taconite ores are disseminated within extremely hard chert-based deposits, they are much more demanding to extract than washable ores, which could be scooped from the earth with front-end loaders. To recover the value found in taconite ores, mining companies had to first fracture the deposit with explosives, then repeatedly crush and grind the ore down to a consistency almost as fine as talcum powder (Kohn and Specht, 1958). Throughout these steps, water was introduced to the ore to help separate the waste from the value. After the taconite ore was reduced to a fineness amiable to concentration, this slurry of iron, water and waste was fed into magnetic separators and gravity classifiers, which essentially produced two products, taconite concentrates and tailings. The concentrates were de-watered, then fed into a balling drum along with 
more water and betonite clay (Hunt, 1951). This mixture was tumbled until the wet clay binded with the taconite forming pellets, which were collected and roasted in a furnace, in order to remove water and also to harden the pellets (Hunt, 1951). The tailings were laundered from the processing plants and deposited into either lakes or basins within 50 miles from mines. Up to 12 different mines used a typical taconite beneficiation plant.

The tailings produced from taconite processing differed from those produced from washable ore in scale and content. Rather than being primarily silica-based, like the tailings produced from washable ores, some tailings produced from taconite processing contained materials such as asbestos which presented new technological challenges for containment (Thistle and Langston, 2016). Taconite tailings were typically dumped into water bodies and basins, rather than on land, and they could migrate far from where they were originally deposited. One such case involves Reserve Mining Company, which mined taconite at the Peter Mitchell mine in Babbitt MN, at the far eastern extent of the Mesabi Range. But rather than process the ore near the mine, Reserve found it more profitable to transport the ore by rail 47 miles to a beneficiation plant in Silver Bay, on the shores of Lake Superior, where the tailings could be dumped into the lake. Assured by the Reserve Mining Co. that tailings would remain contained within a deep trench in the lake, in 1947 the State of Minnesota granted permission to Reserve to dump its tailings into Lake Superior. In 1955 the company's plant began operations (Manuel, 2015; Thistle and Langston, 2016). Yet Reserve's tailings, and the asbestiform fibers within them, mobilized through the western arm of Lake Superior, eventually contaminating the drinking water supply of Duluth (Thistle and Langston, 2016). After years of controversy, the United States filed a lawsuit against Reserve in February 1972, seeking 
abatement of the tailings discharges into Lake Superior. In March 1980, the dumping of taconite tailings into Lake Superior was finally halted, after a long series of federal and state lawsuits against the company. The environmental consequences of Reserve remain contested, although recent research shows that taconite miners on the Mesabi Range have an increased risk in developing mesothelioma, a fatal lung disease linked to asbestos exposure (Finnegan and Mandel, 2014).

\section{Data and Methods}

To illuminate how the technological shifts to low-grade iron ore mining created different forms of waste in the Lake Superior basin, we designed a Historical Geographic Information System (HGIS) database. This HGIS database allows us to map and analyze the impacts of historical mining spatially, illuminating the time-space patterns of ore production and the locations where waste was produced within the Lake Superior Iron District, spatial patterns that research in the archives alone would not reveal. Our HGIS database helps us reconstruct the historical landscape of the Lake Superior Iron District, and explore how shifts in technology over time placed new demands on the environment, specifically where ore was extracted and where new waste was laundered.

\subsection{Placing Mines on the Landscape}

We constructed our HGIS by integrating a host of primary archival data, secondary textual source material, and publicly available datasets related to mining in the Lake Superior Iron District. Our first step required identifying what iron mines existed in the Lake Superior Iron District, and then locating them in space and time. The United States Geological Survey (USGS) maintains a fairly complete and accessible GIS database called the Mineral Resource Data System 
(MRDS), consisting of locational data for active and historical mines within the United States. The USGS database contains the spatial coordinates of individual mines stored as a point-based shapefile. We selected our data from a geographical search tool which generated a shapefile consisting of over 400 individual iron mines that once operated in the region. To remove possibly redundancies and crosscheck the accuracy of the locational data within the MRDS database, we then compared this shapefile with a mineral dataset acquired from MinDat, a non-profit organization focused on developing inventories of mining properties.

We then collected historical qualitative and quantifiable data for building the HGIS which would allow us to spatially analyze changes in mining and waste production over time. This included identifying mine owners and mine operators, determining the type of ore extracted, calculating years of mine activity, and adding the annual tonnage of ore produced. Historically, the quantity of ore shipped from a mine was recorded at number of locations: on scales at the mines before the ore was shipped to ports; at the port of origin; and at the final destination, such as iron furnaces in Cleveland (Iron Trade Review). For the mining companies, it was important to keep an accurate record of annual ore shipments so that state taxes owed could be determined. Accurate ore weights also signaled to investors and shareholders the progress made during the year (Parks, 1949). For the shipping companies, an accurate measurement of how much the ore weighed was essential for calculating what they would charge the mining companies for freight, as well as in ensuring that the shipping companies were staying within their shipping quotas. Finally, the iron furnaces at the end of the transaction weighed the ore again to ensure that there were no discrepancies between the logs at the mine, the ports, and at the furnaces. The end result of all of this weighing was 
annual shipment logs for the Lake Superior Iron District published in mining and steel-industry trade journals. For our analysis, the quantities of ore shipped were the critical, quantifiable measurable that we used in recreating historical waste footprints.

We located our data from three key mining journals: The Iron \& Trade Review; Steel; and Skillings' Mining Review. We extracted and entered 11,447 individual entries of iron ore shipments from mines in the Lake Superior basin for each year between 1898 and 1981, along with the quantities of taconite mined in Minnesota from 1950-2010 as reported in the Minnesota Mining Tax Guide, published by the Minnesota Department of Revenue. We cross-checked data for accuracy by comparing the ore shipment data from these trade journals and with mine shipment data provided in annual USGS reports.

The annual mine production data was entered into the HGIS, with a unique identifier linking each mine through time. Individual points, each representing a year of mine shipping activity at a given geographic location allow us to create a visual representation of mine shipments over time. For instance, if the La Rue mine shipped ore in 1906, 1907, 1909, and 1933, the HGIS would have four points associated for the La Rue mine, one for 1906, 1907, 1909, and 1933. These points would all share the same spatial coordinates, but each point would be representative of the individual year that the La Rue mine shipped iron ore. By adding this shipment data to our HGIS, we now had both the locational coordinates of the mines and also data that showed annual production totals per individual mine over time.

\subsection{Recreating a Landscape of Beneficiation}

Where were low-grade ore processed in the Mesabi Range and the greater Lake Superior Mining District? With the exception of 
modern taconite plants, the answer to this question was widely unknown. Government agencies, such as the USGS, have an inventory of the locations of active and abandoned mines, but no agency has maintained a similar inventory for the facilities that processed ores, produced tailings, and the location and extent of such tailings. Since there has been no prior investigation into the history of beneficiation in the Lake Superior district, we elected to explore not only where mines were located, but also where the low-grade ores were processed, and how much waste they produced.

To accomplish this, our next step in building the HGIS was to identify which mines were treating low-grade ores and producing tailings. This step required re-examining trade journal reports and the USGS Minerals Yearbook, an annual publication that reported mining highlights of individual minerals from the past year. After we located the mines first producing washable ores, and later taconite, we next needed to identify where these mines were treating these low-grade ores, specifically, where were the beneficiation plants? Identifying where the processing plants were located and when they operated was not as straightforward as locating the mines themselves, since there is no existing federal inventory of these facilities. To produce a database of beneficiation plants, we needed to create an entirely new historical spatial dataset from a number of historical sources.

To create an inventory of beneficiation plants within the Lake Superior District, we consulted trade journals, historical maps, Minerals Yearbooks, reports from the Lake Superior Iron Ore Association, and historical aerial imagery, searching for plant construction dates, locational information, and the names of mines that sent their ore for treatment. Next, we compared the findings from these historical records with contemporary aerial imagery looking for standing structures or structural footprints of these facilities. Since 
much of the Mesabi Range is heavily vegetated, forest cover often obscures a high percentage of potential structural footprints.

LIDAR data for the state of Minnesota is available to the public, which allowed us to look through the vegetation that is obscuring more of the subtle surface features. Analysis of LIDAR data helped reveal the subtle footprints that these concentrating plants left behind, helping us reaffirm and pin-point their locations (See Figures 2.2 and 2.3).

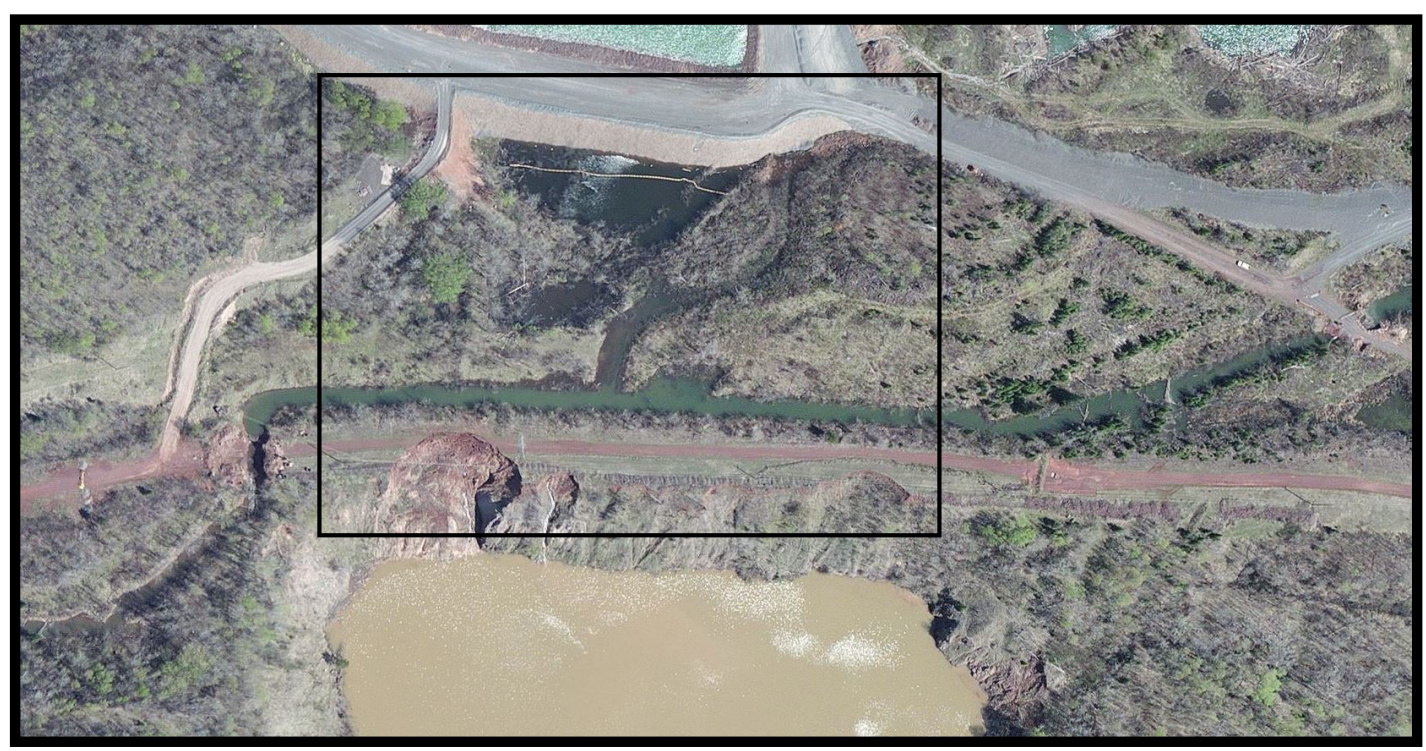

Figure 2.2: Contemporary aerial image of the Columbia washing plant. The vegetation makes pinpointing the plant's former location difficult (MNTOPO) 


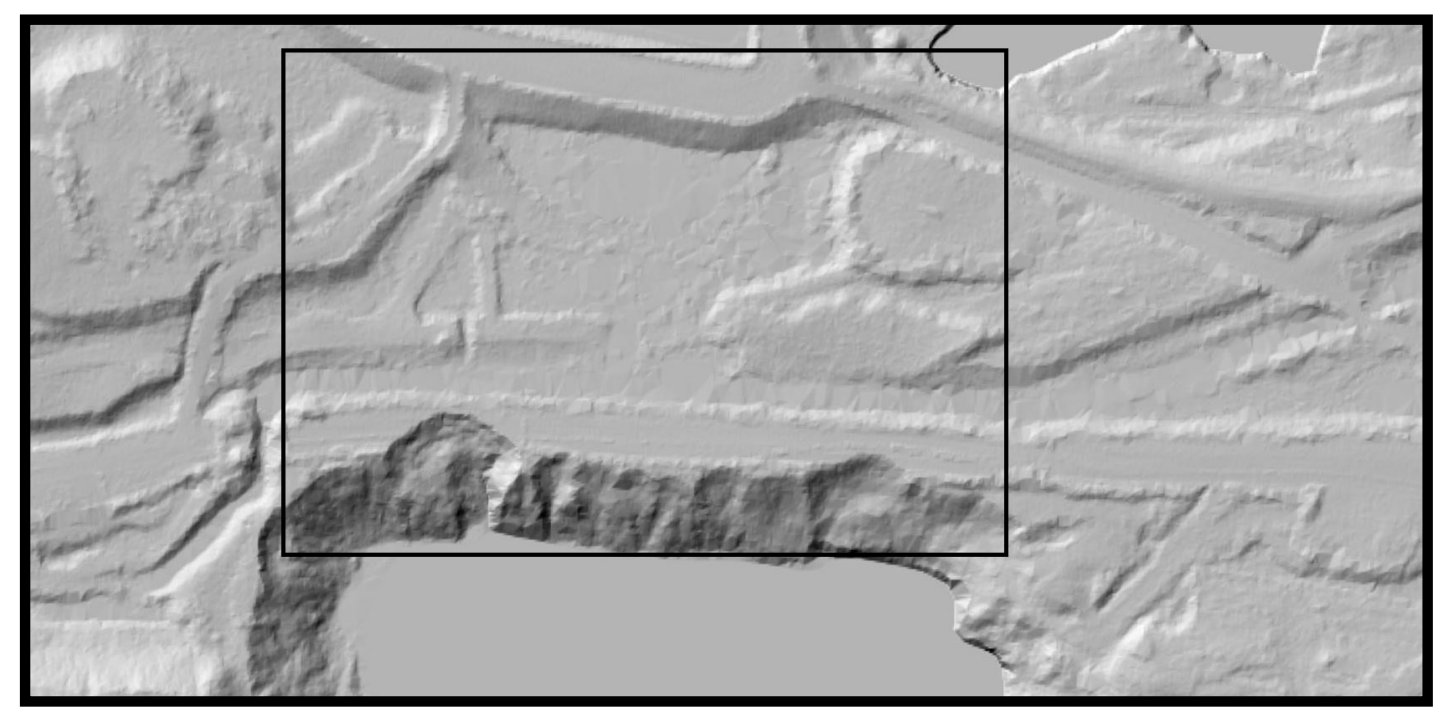

Figure 2.3: LIDAR Imagery of the Columbia washing plant reveals the defined footprint of the plant not visible on aerial imagery (MNTOPO)

We consulted LIDAR data provided by MNTOPO, a web-based mapping resource managed by the Minnesota Department of Natural Resources and the Minnesota Geospatial Information Office. MNTOPO utilized an airborne LIDAR survey that produced digital elevation models for the state of Minnesota. These digital elevation models filter out vegetation and show surface features that appear due to elevation changes.

Next we created a new GIS database consisting of the location, name, operating years, and owner/operator information for these historical beneficiation plants throughout the Lake Superior District. We then spatially joined the mines that were producing low-grade ores to the beneficiation plants that were processing this ore, using data from trade journals and Minerals Yearbooks, as well as comparing the operator/owner of the processing plants to adjacent low-grade ore mines. For many mines this was a simple step. If the beneficiation plant was located nearby a mine with the same name, and owned by the same mining owner, we can infer that this plant was processing 
ore from this mine. But smaller mines sent their ore to custom beneficiation plants, facilities designed to treat ores from a variety of mines rather than a single mine. We determined these processing locations by consulting annual shipment records of the mines, which often included additional information regarding the ore, such as if it was taken from a stockpile, or where it was treated. We next joined the mines and their production data to the beneficiation plant geodatabase. The resultant HGIS consisted of mine production totals for direct shipping ore mines, washable ore mines, taconite mines, and essential beneficiation information that we could use to calculate the new waste production from low-grade ore processing.

We calculated averages from plants that reported production statistics in technical reports to create a formula for the tons of tailings per ton of shipped ore. For washable ore beneficiation plants, we used data from technical reports for the Trout Lake, Hawkins, LaRue, and Harrison concentrators, as well as government surveys tailored for the iron and steel industry (Taggart, 1927; Tupper, 1912; Walling and Otts, 1967). To calculate tons of tailings produced for each ton of taconite produced, we drew on statistical reports from the Reserve, Minntac, Erie, Eveleth, and Butler taconite plants (Cummins and Given, 1973).

We next digitized the contemporary waste footprint seen on the Mesabi Range. This process involved digitizing the visible waste and mining activity seen on aerial imagery from 2012. Locating and digitizing the waste footprints from taconite plants was the easiest step, since these facilities are the most recent producers of mine waste, and have the largest waste footprints. The waste footprints produced from washable ore plants were harder to locate, as some of these tailings piles have become re-vegetated, or appear as lakes in imagery. Comparing the locations of the plants to the aerial imagery 
helped illuminate some of these more obscured waste footprints.

\section{Results}

\subsection{Mapping mines}

We first mapped all iron mines, historic and current, in the Lake Superior Iron District. Figure 2.4 shows their locations. Historically, over 400 individual mines once operated in the six iron ranges. Some of these mines only operated for a handful of years, while others successfully functioned for nearly a century. Although mines were located throughout the district, the Mesabi and Marquette Ranges contained the most productive and long-lived mines.

\section{Extent of Iron Mining Across the Lake Superior Iron District}

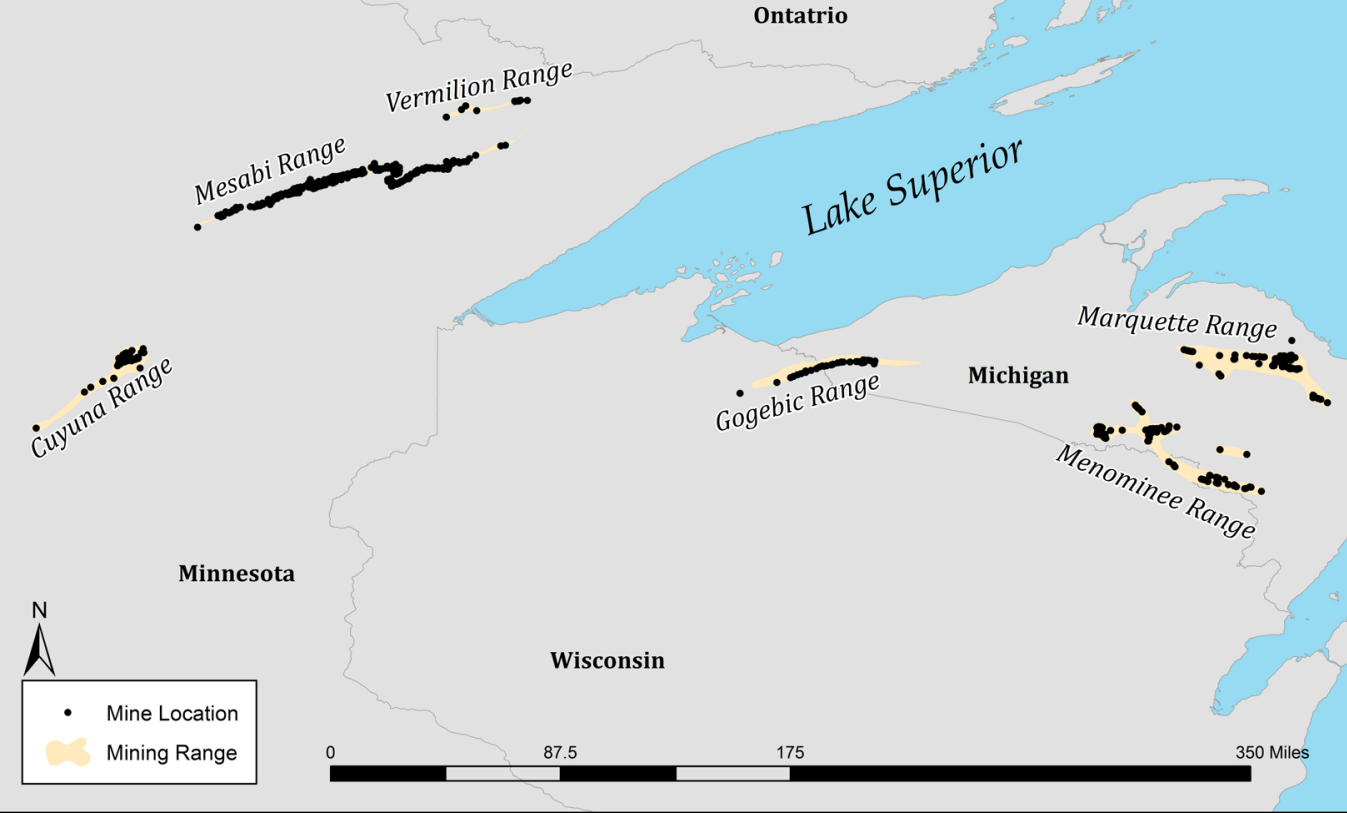

Figure 2.4: Iron mines within the Lake Superior Basin

We next mapped the changing dispersal of mining locations over time, as technologies shifted (Figure 2.5). With the shift to low- 
grade ore mining, we found that spatial shifts occurred in the Lake Superior Iron District, most notably with a concentration of mining activity in the Mesabi Range, and the abandonment of mining in the Gogebic, Vermillion, Menominee, and Cuyuna Ranges.

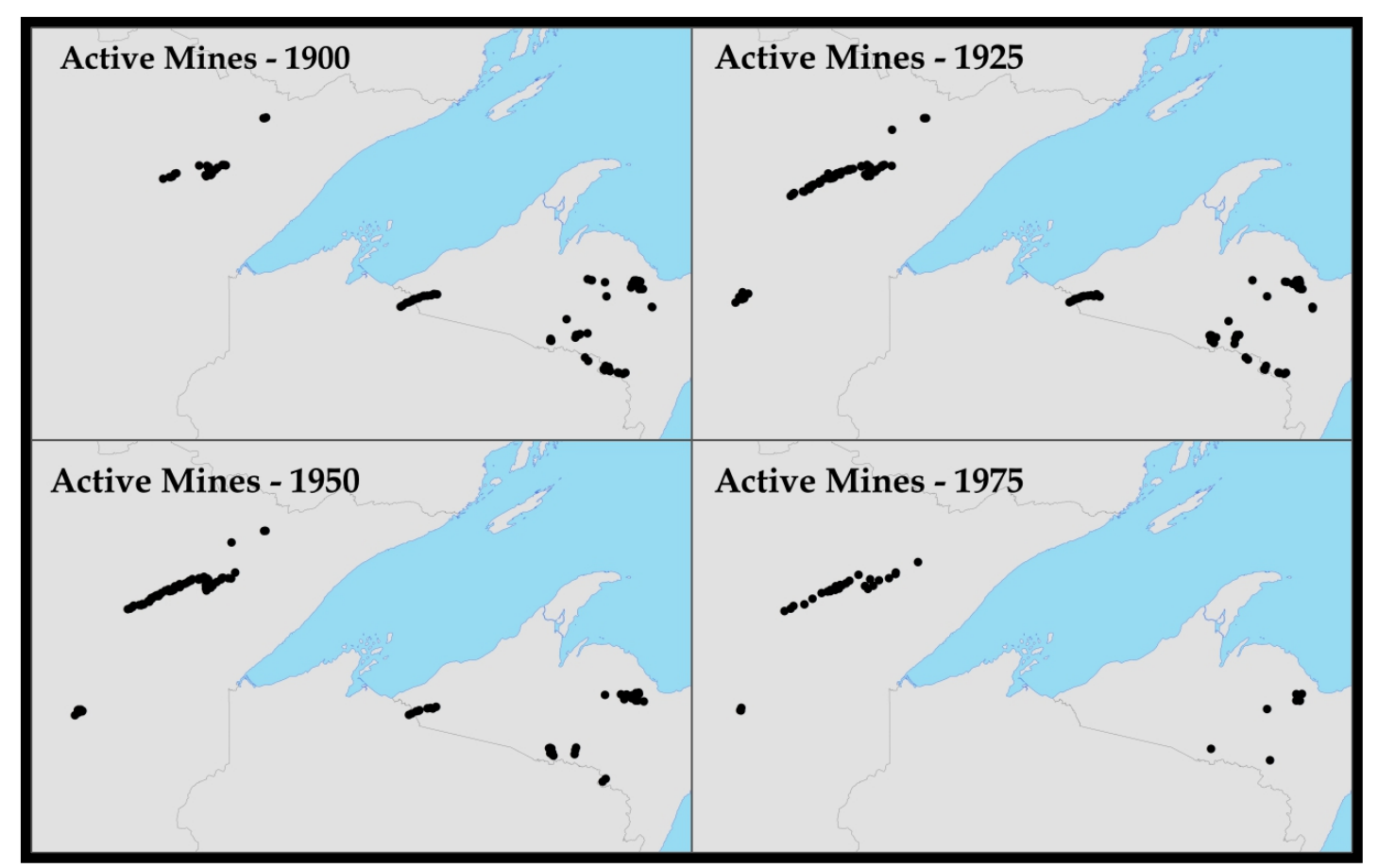

Figure 2.5: Mine locations in the Lake Superior Iron District from 1900-1975

We next examined how the concentration of ore production changed as mining locations changed (Figure 2.6). Figure 2.6 uses proportional symbols to show annual ore production totals per mine across the Lake Superior District. The transition to low-grade iron ore mining resulted in an increased production of iron ore at a shrinking number of mine locations. This created an intensification of mining activity within concentrated pockets, located primarily within the Mesabi Range. Since the Mesabi Range contained the largest quantity of low-grade ores, the mining activity in that region produced the largest quantity of low-grade ores. 


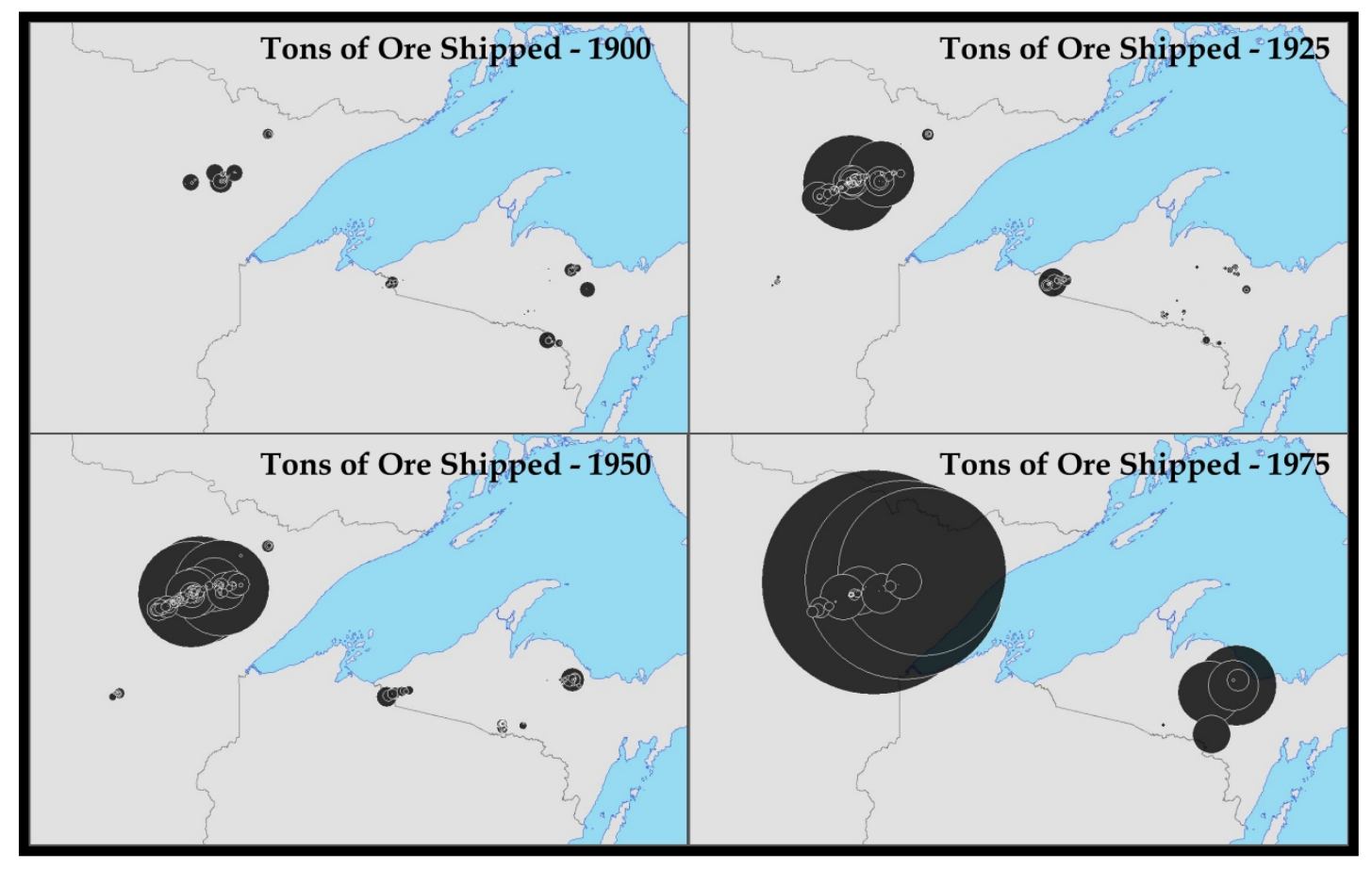

Figure 2.6: Changing Quantities of Ore Shipped from Mines Within the Lake Superior Iron District

\subsection{Mapping technological shifts}

Figure 2.7 shows how different mining technologies compared in terms of ore shipments. By categorizing which technology was employed at an individual mine or processing plant, we were able to quantify how much ore was extracted and processed by a specific mining technology. Our analysis also shows that as mining in the Mesabi Range shifted to low-grade ores, the quantity of ore leaving the region increased dramatically between 1937 and 1972, but fell after 1981. While direct shipping ore played an important role in the Mesabi Range up to the late 1950s, the impact that low-grade ores had on the region grew from 1920 to today. Charting the ore shipments from the Mesabi Range also revealed a notable rise and fall in iron ore production from 1980-1982, possibly related to the economic recession of 1981. 


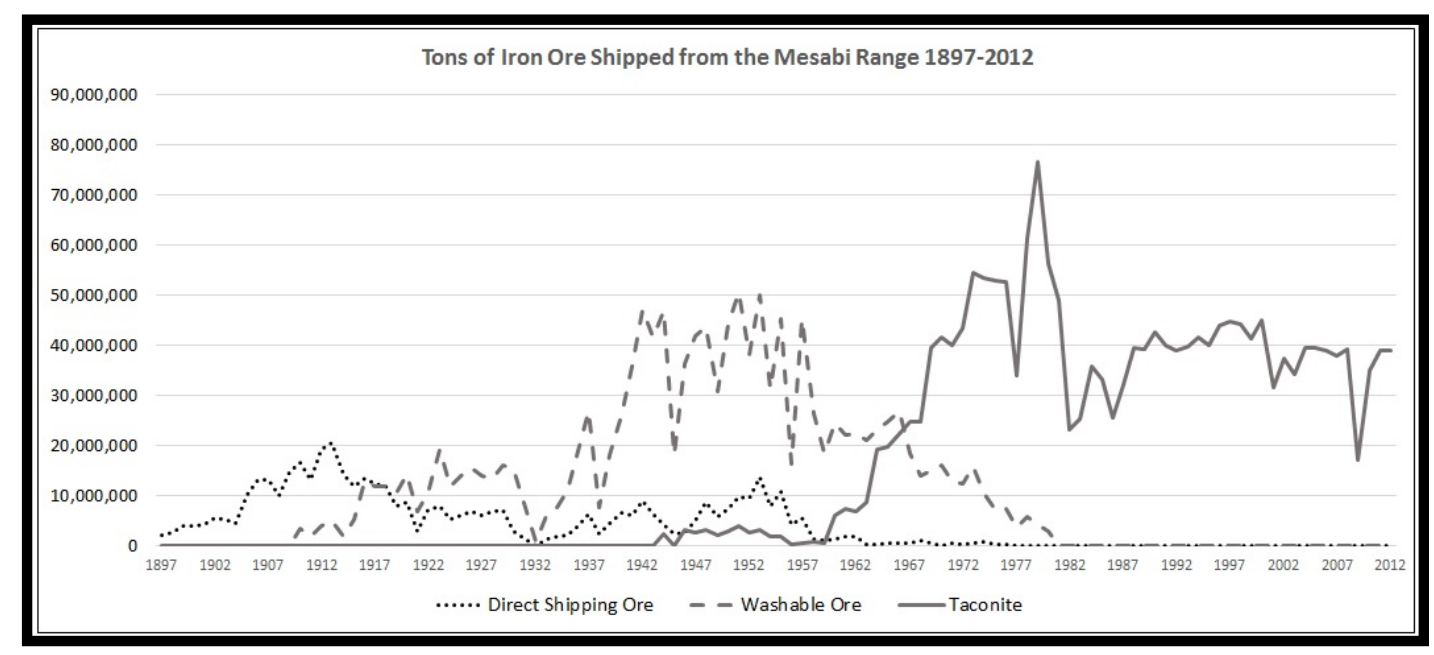

Figure 2.7: Tons of iron ore shipped as produced by different mining technology within the Mesabi Range

Grouping ore shipments by technology revealed spatial shifts that occurred in iron ore extraction, shifts that were not apparent by examining the shipment data alone. For instance, as washable ores became a growing source of iron for the Mesabi Range, mining activity in Itasca Co., within the western extent of the Range, became much more pronounced. As mining shifted towards taconite, the eastern Mesabi Range retook control as the Range's primary producing region.

Additionally we see a spatial shift in beneficiation across the Lake Superior district. Figure 2.8 shows the extent of low-grade iron ore beneficiation across the Lake Superior Iron District from 1910 to today. Although iron ores were beneficiated in every range within the district, the Mesabi Range contained the most beneficiation plants, owing to the abundance of low-grade washable ores and taconites found throughout the Range. 


\section{Extent of Iron Ore Beneficiation Across the Lake Superior Iron District}

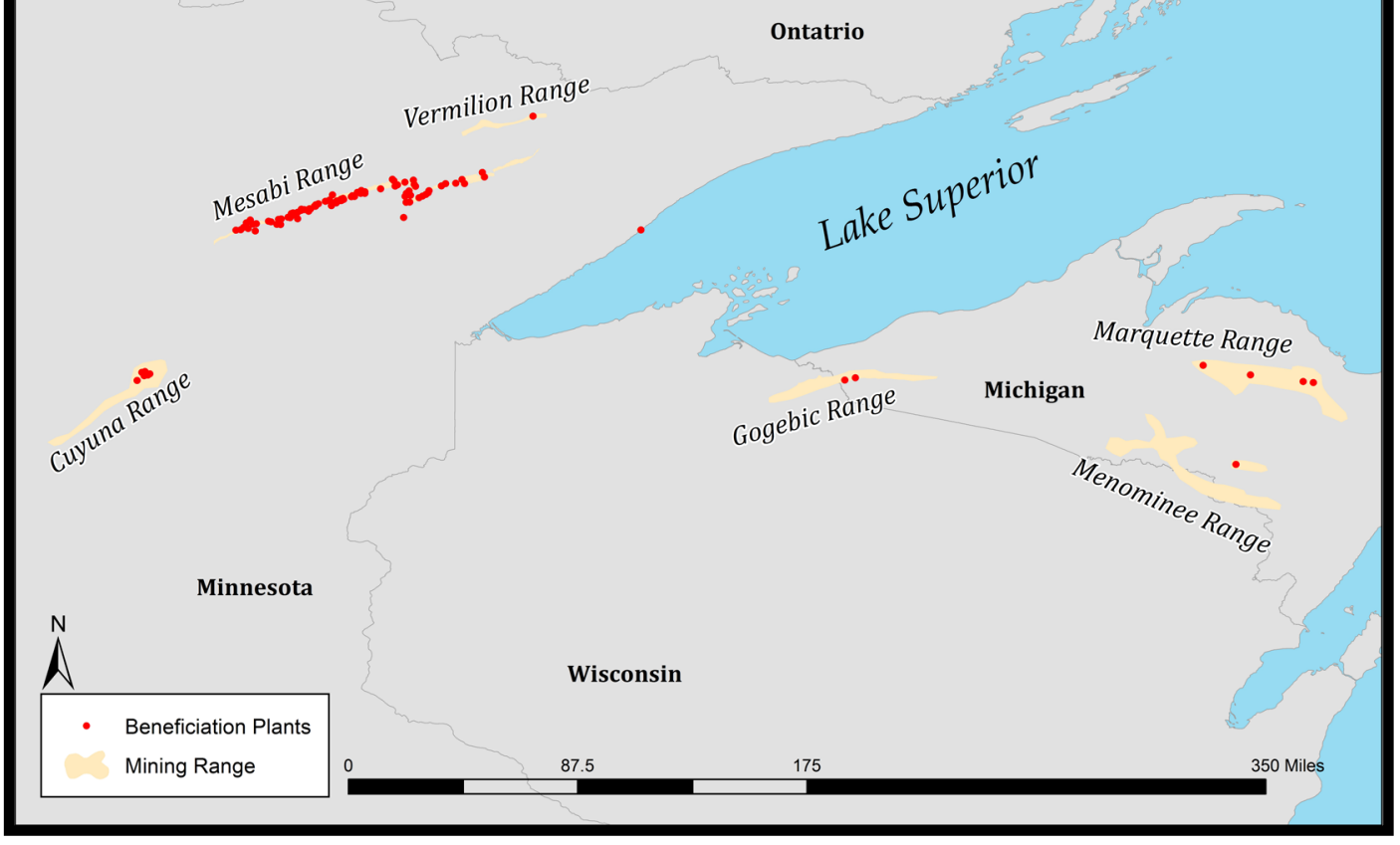

Figure 2.8: Locations of beneficiation plants in the Lake Superior Iron District

Beneficiation technologies varied across the Mesabi Range.

Figure 2.9 illustrates the spatial patterning of two of these technologies. As several mines could ship to a single beneficiation plant, mapping these locations was a complex task, necessary in order to quantify and map the new waste footprints that this processing created. Our HGIS, which contains the first database of iron ore processing plants in the Lake Superior basin, shows that the beneficiation of low-grade ores occurred in every mining range in the District, but the Mesabi Range contained the largest proportion of these ores and the facilities that processed them. . 


\section{Iron Ore Beneficiation Plants in the Mesabi Range}

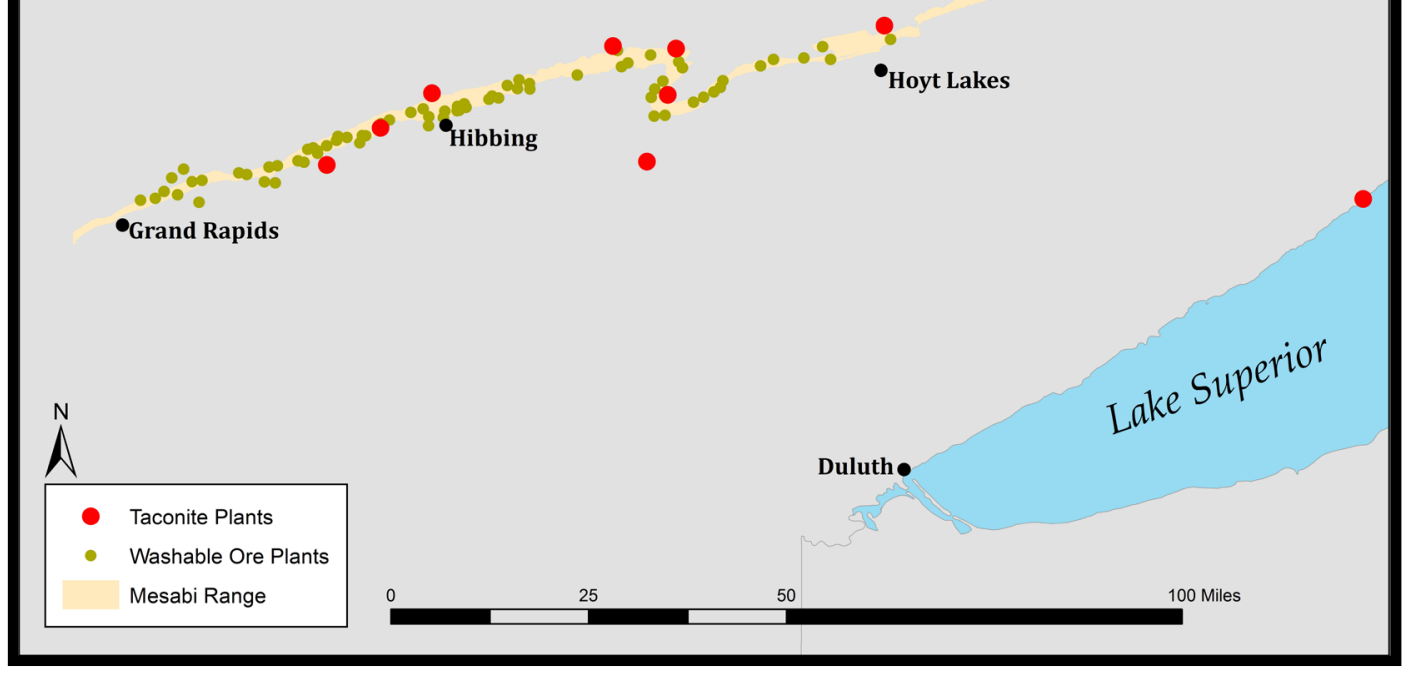

Figure 2.9: Beneficiation plants within the Mesabi Range

Creating this beneficiation plant database allowed us to identify where waste was produced and deposited from the processing of lowgrade ores, and analyze how much waste each technology was producing. We will draw on this analysis in future papers that explore how mining activity has impacted watersheds in the Lake Superior Basin.

\subsection{Mapping Tailings}

To quantify the tailings deposited by different beneficiation plants, we needed to determine the average tons of tailings produced for each ton of ore processed. Since mining companies did not report the production of tailings in the same way that they reported ore shipments, we determined tailings quantity for each ore type by 
consulting historical trade journals, such as the Engineering and Mining Journal and Skillings' Mining Review, as well as processing results found in mining and metallurgy handbooks, such as Taggart's Handbook of Ore Dressing and the Society of Mining Engineers' SME Mining Engineering Handbook. These reports provided production statistics for the beneficiation plants, such as tons of crude ore versus concentrates produced, the remainder of which would equal the quantity of tailings, while others provided ratios of concentration, such as 1.6 tons of crude ore to 1 ton of concentrates. Figure 2.10 represents a hundred years of tailings deposited on the Mesabi from low-grade ore processing.

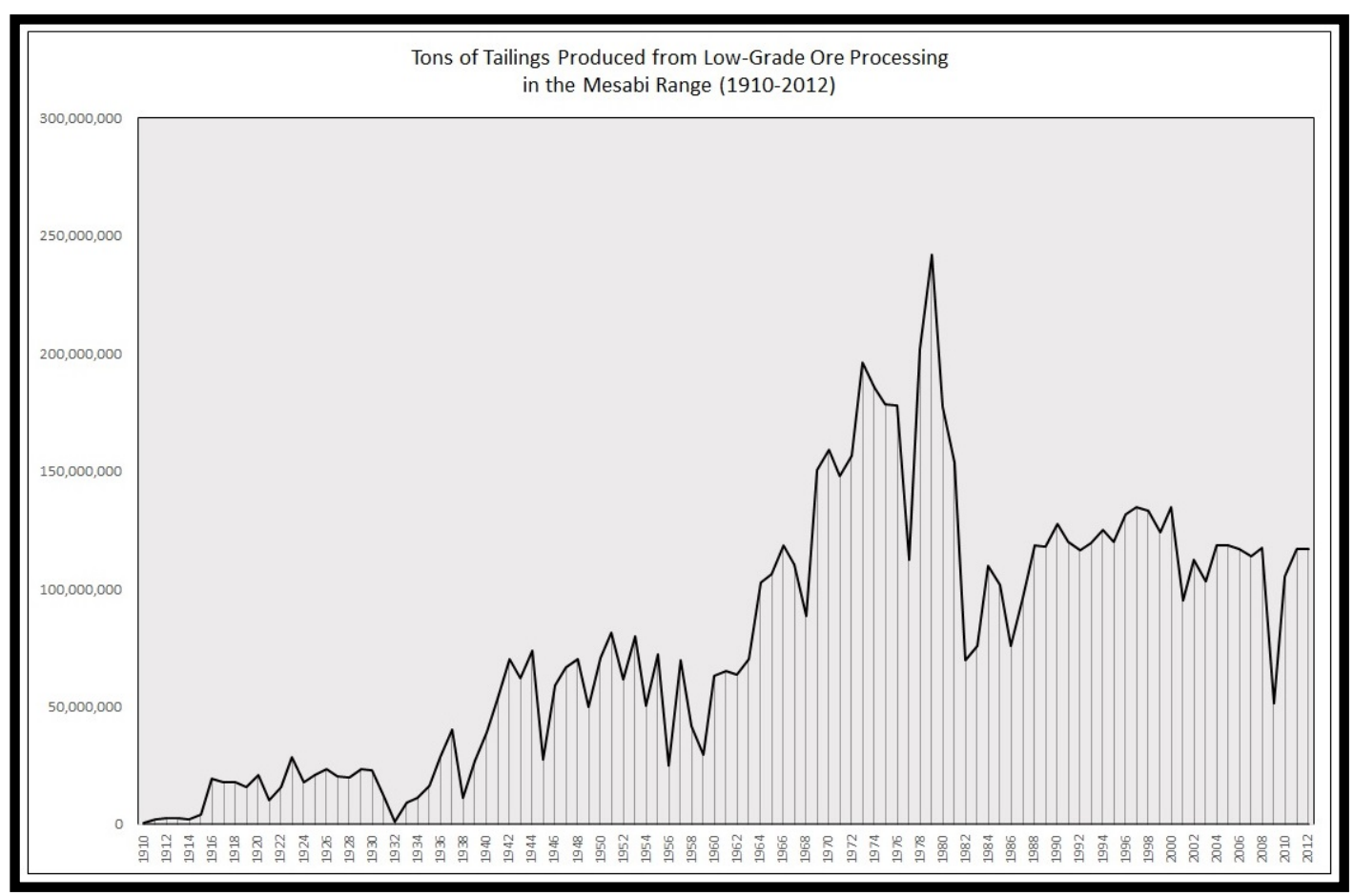

Figure 2.10: Total tailings production in the Mesabi Range

How did technological changes affect the average quantity of iron ore shipped and tailings deposited in the Mesabi Range? Figure 2.11 outlines the production of ore and tailings by technology and then averages those total by individual facilities. For each technology, 
we divided the total quantity of ore shipped and tailings produced from all mines or processing facilities using a particular technology by the number of individual mines or processing plants using that technology. Within the Mesabi Range, 238 direct shipping ore mines shipped 469,184,394 tons of iron ore and created 0 tons of tailings; 78 washable ore processing plants shipped a total of 1,360,538,166 tons of washable ore concentrates and created 2,035,641,670 tons of tailings; and 10 taconite processing plants shipped a total of $1,972,465,460$ tons of taconite pellets and created $6,051,680,659$ tons of tailings. These data support our argument that as mining technologies changed in the Mesabi Range, production became concentrated. Fewer facilities processed an increasing quantity of ore and dumped an increasing concentration of tailings in smaller areas. 


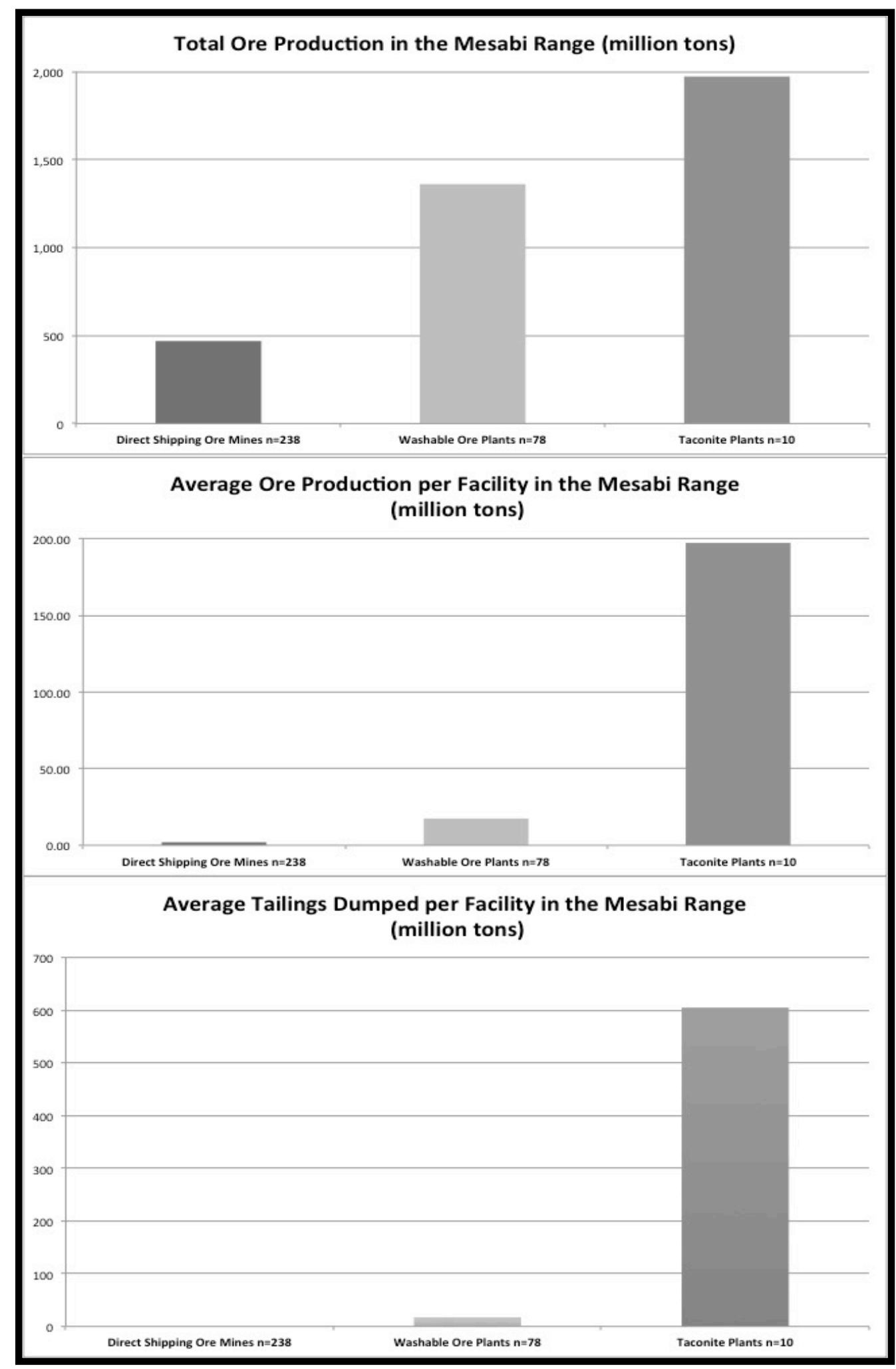

Figure 2.11: Tons of Iron Ore Shipped by Individual mines or processing plants in the Mesabi Range from 1898-2012 
Figure 2.11 shows the production statistics from the three different phases of mining in the Mesabi Range. The chart highlights the increase in tailings production, which occurred during the shift to taconite mining and ore processing. Furthermore, this chart shows that while there were a significant larger number of washable ore plants (88) than taconite plants (10), the waste footprint produced by taconite processing was nearly three-times that of washable ores. The locations of processing plants and the quantity of tailings these plants produced changed over time.

As we view the production of tailings over time we see a distinct spatial shift in where the tailings were being deposited across the Mesabi Range (Figure 2.12). As low-grade iron-ore mining matured, the production of tailings within the Mesabi Range became less widespread, but the quantity of tailings grew in scale. This resulted in a high production of tailings located next to a dwindling number of processing plants. 


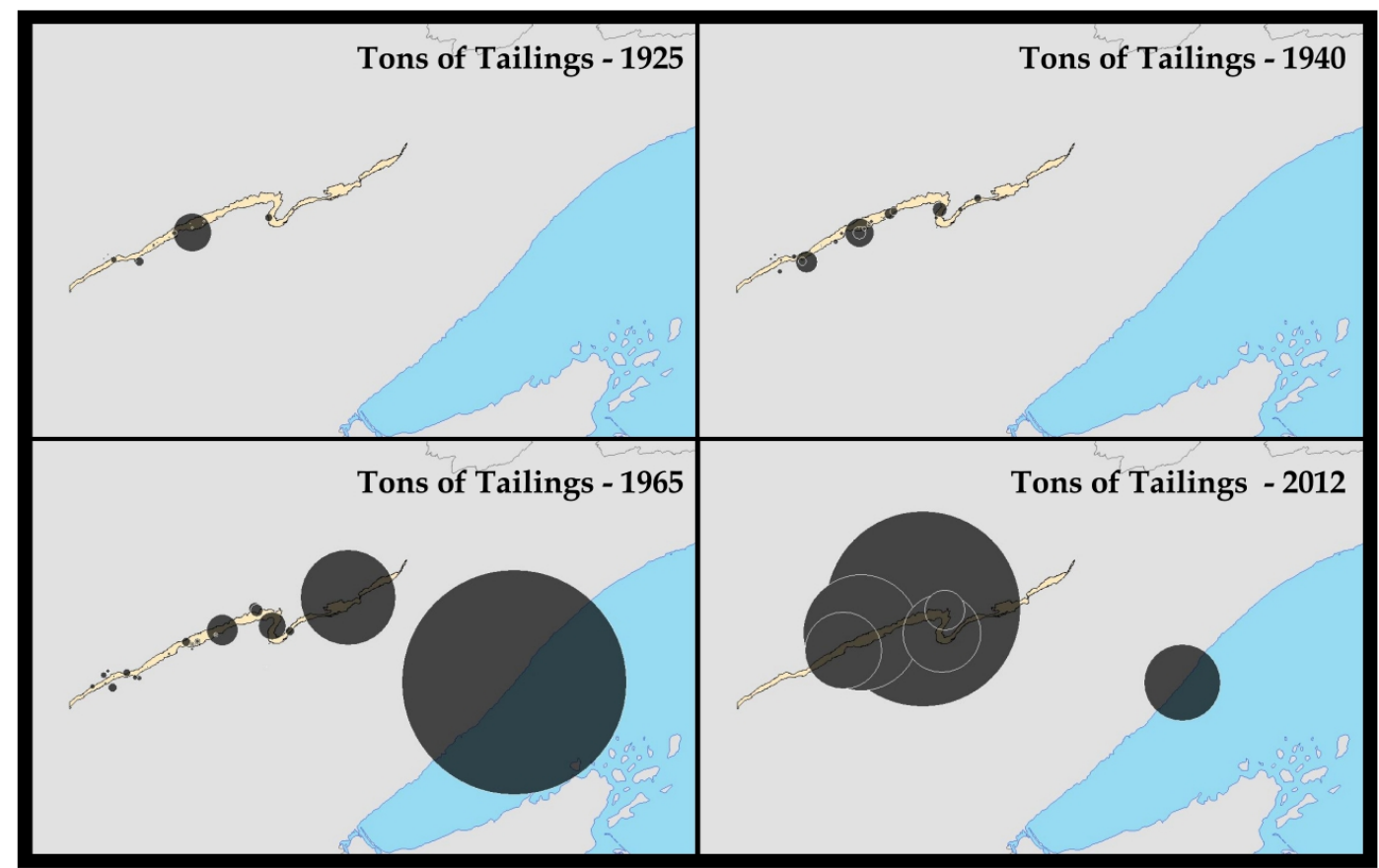

Figure 2.12: Changing quantity of tailings produced in the Mesabi Range

Adding the tailings productions statistics to our HGIS allowed us to quantify and visualize the waste produced by a specific mining technology across space and time. Historically, 103 beneficiation plants were located in the Lake Superior Iron District, and 88 of these were found in the Mesabi Range. By the early 1980s, over $85 \%$ of these plants were scrapped and removed from the landscape. Today 13 beneficiation plants remain standing in the Mesabi Range, 9 of which processed taconite ores. Our survey of historical records showed that, on average, washable ore produced 1.5 tons of tailings per ton of washable concentrates produced. Taconite processing produced significantly more tailings; nearly double that of washable ores, at 3 tons of tailings for every ton of taconite pellets produced. As mining in the Mesabi Range progressed from direct shipping ores, to washable ores, and to taconite, the waste footprints became exceedingly larger 
Knowing where production facilities existed provided us with locational data that we could use to pinpoint the visible waste footprints that these plants might have created (Figure 2.13). Figure 2.13 maps the extent of visible mine waste as it compares to the Biwabik Iron Ore formation that made up the Mesabi Range. The Biwabik formation was 100,000 acres in totals area, while the waste footprint totaled 125,000 acres, making the waste landscape substantially larger than the original ore body itself.

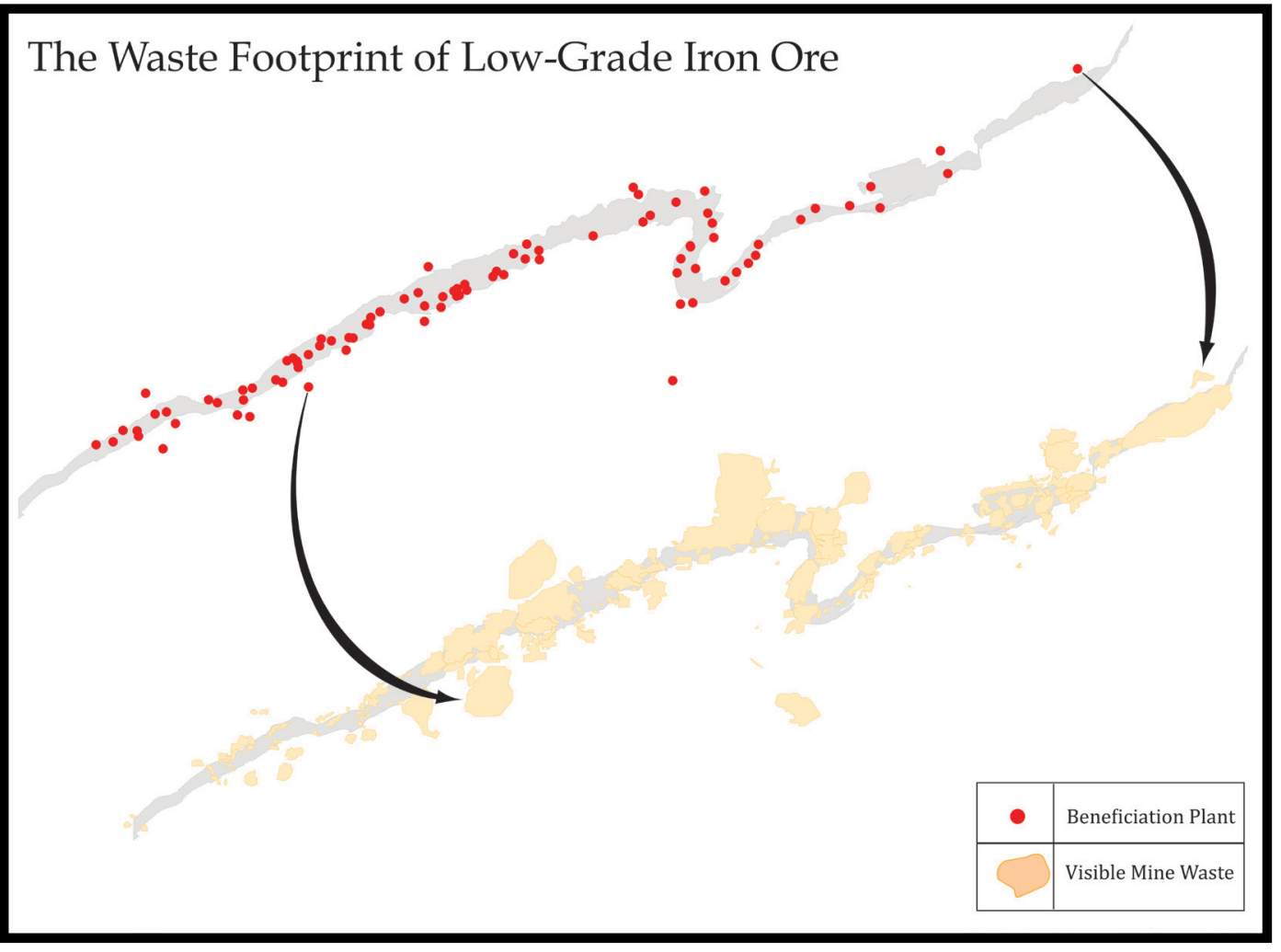

Figure 2.13: The landscape of mining waste that covers the Mesabi Range

The prevalence of mining waste seen in contemporary and historical imagery was used as an important comparative factor when assigning these scrapped historical facilities locational data in our HGIS database. Since mine waste is so prevalent throughout the 
Mesabi Range, we decided to try to group the visible mine waste by the specific technology that produced it. This process involved analyzing the location of direct shipping ore mines and the washable ore and taconite beneficiation plants, and the occurrence of nearby mine waste.

Many locations where direct shipping ore mines once existed were later mined for either washable ores or taconite, open-pit mining processes that consumed the historical footprint left by these direct shipping ores. This succession of mining technologies made it difficult to isolate a large percentage of mining waste related to the early twentieth century direct shipping ores. We were however able to locate five direct shipping ore mines, located in relative isolation from either washable ore mines or taconite mines. To calculate the estimated quantity of surface waste produced from direct shipping ores, we vectorized the contemporary footprints from the aerial imagery and measured their extent in our HGIS. The average visible waste footprint for these five direct shipping ore mines was 120 acres. This value was assigned as the waste footprint score of the remaining mines that were engaged with direct shipping ores in the Mesabi Range.

Since the visible waste acreage associated with washable ore mines was located adjacent at their processing plants, we again vectorized and measured the contemporary visible footprints from the aerial imagery in our HGIS. The total acreage of waste at these 71 washable ore processing plants was 60,186 acres. This results in an average of 847.69 acres of visible waste per washable ore plant.

Mining waste from taconite mining was also primarily located next to the taconite processing plants. To calculate an average waste footprint for taconite ore processing, we used the same methodology used for washable ore processing plants. The total acreage of waste at these 10 taconite processing plants was 67,175 acres in the Mesabi 
Range (not including Reserve Mining Co.). The waste footprint of Reserve was not calculated since the processing facility is located at Silver Bay, MN on Lake Superior, roughly 65 miles SE of the eastern extent of the Mesabi Range. This results in an average visible waste footprint of 6717.45 acres per taconite plant. From this analysis, we see that the waste footprint associated with individual mining technologies grew significantly as the Mesabi Range experienced a technological shift from direct shipping ores, to washable ores, and to taconite.

\subsection{Mapping Shifting Concentrations of Mining and Waste}

We hypothesized that the shift from mining direct shipping ores, to low-grade washable ores and taconite placed new demands on the environment of the Lake Superior Basin, and that this shift created intensive pockets of industrial activity located next to processing plants rather than the mines themselves. We used an average nearest neighbor analysis which measures the relative clustering or dispersal of a set of observations on a landscape. Expressed as a ratio, a nearest neighbor ratio less than 1 suggests clustering, and a ratio greater than 1 suggests dispersal. Our analysis of a hundred years of mining activity across the Mesabi range suggest a dispersion of activity over time, with the early direct shipping ore mines having a nearest neighbor ratio of 0.427 , mid-century washable ore plants a ratio of 0.428 , and the more recent taconite plants a ratio of 1.17.

Additionally, the average nearest neighbor analysis showed that there was an observed mean distance between direct shipping ore mines of 552 meters; for washable ores, an observed mean distance of 1,563 meters between washable ore plants; and for taconite ores, an observed mean distance of 12,619 meters between taconite plants. The average nearest neighbor analysis showed that there was a 
significant clustering pattern associated with direct shipping ore mines and washable ore plants, while taconite plants are not clustered.

These results suggest that as mining in the Mesabi Range shifted from direct shipping ores, to washable ores, and to taconite ores, the spatial intensity of mining became more dispersed, transitioning from a mining landscape with a large number of spatially clustered mines and ore washing plants, to one with a low number of taconite plants that are distributed at great distances from each other across the landscape. Additionally, we see that the shift to low-grade iron ore mining and processing resulted in a substantial increase in the density and size of the sites of ore extraction and waste production, which led to an increase in the scale of ore extraction and tailings production around a smaller number of mines and processing plants.

\section{Discussion}

The modern landscape of the Mesabi Range reflects more than 120 years of intense mining activity. While the ores that were extracted from the mines have left the region, an immense amount of mine waste remains. Today, a tremendous volume of open-pit mines and mine waste account for an area larger than the Mesabi's iron formation itself. Viewed from above, the Mesabi Range appears as a vast assortment of amorphous brown islands among a sea of green vegetation.

While the physical footprints of many of these beneficiation plants are difficult to identify today, their legacies of waste remain evident artifacts on the landscape. Today, the footprints of less than $25 \%$ of the beneficiation plants are visible from aerial imagery, yet the tailings from these plants are apparent at over 90\% of the sites where 
these plants once operated. These tailings were first dumped directly into water bodies located nearby the processing plants, and later within constructed basins, where mining companies could reclaim this waste if a new technology was developed that could convert the tailings into ore.

Because our HGIS contains annual ore shipment data from 18982012, we were able to chart how much ore was shipped out of the Lake Superior Iron District over time, revealing spatial patterns of declines and increases in shipping totals and tailings deposition across the basin. Our HGIS reveals that as taconite mining matured in the Lake Superior basin, the waste footprint of mining became concentrated near the beneficiation plants located primarily in the Mesabi Range. Future research explores possible links between concentrations of ore mined and waste deposited, and landscape-level effects on water quality in the Mesabi Range.

This study shows that the technological shift to low-grade iron ore intensified mining production and waste deposition within the Mesabi Range. The advent of low-grade iron ore concentrating created new environmental impacts, namely tailings. Prior to 1910, iron ore tailings did not exist within the Lake Superior Iron District, but as the shift to low-grade iron ore mining intensified tailings became a dominant feature on the mining landscape. Additionally, before lowgrade ore mining, mine waste existed primarily within the immediate mining landscape, where it remained as a static feature encountered by mine workers. The beneficiation of low-grade iron ores took mine waste outside of the immediate mining landscape, where it was crushed and made mobile, laundered it into lakes, and encountered by the public. This resulted in a new negotiation between industry, the state, and private landowners regarding the environmental costs of an industrial economy. 
With the development of taconite mining and beneficiation during the 1950s, the facilities that processed low-grade ores also experienced spatial shifts. Many of the facilities that had processed washable ores in the region were abandoned. The shift to taconite mining during the 1970s also reduced the number of mines while increasing the quantity of ore extracted and the quantity of tailings produced near processing facilities. As ore and waste production increased, the number of mines and beneficiation plants shrank, concentrating waste products into fewer watersheds with greater individual impacts. The shift to low-grade iron ore mining in the Lake Superior District created concentrated pockets of industrial activity located around iron ore processing plants.

A limitation of this study is the fact that, while we have an accurate estimate of waste volume calculated from ore production, we underestimate of the area of the range currently covered by mine waste. The maps of current waste only include waste that was visible on maps or with LIDAR. An additional proportion of waste produced from both washable ores and taconite ores could not be mapped, because it had been deposited into lakes. Furthermore, the tremendous amount of mine waste produced from the Reserve Mining Company between 1955 and 1980 are not part of this analysis as they were dumped into Lake Superior, far from the Mesabi Range.

The technological shift to low-grade ore mining created a landscape of open-pit mines spanning across the Mesabi Range. The expansion and subsequent abandonment of low-grade ore mining transformed the Mesabi Range from an industrial landscape of mines and processing plants, into a post-industrial landscape dominated by mine-pit lakes and mining waste.

This study has created the first database that encompasses the locations of where low-grade iron ore beneficiation took place, as well 
as the quantity of waste that was produced as tons of iron ore were processed. Historically, 88 iron ore processing plants once operated on the Mesabi Range. Today, only a handful of these plants remain visible, as the majority were removed for scrap decades ago. These plants now exist as ghosts on landscape, visibly absent yet environmentally persistent. Surprisingly, we found that the waste landscape of mining--the tailings basins, open-pit scars, and mine waste--today covers $125 \%$ more acreage than the original iron formation itself.

Mine waste is a key component to this study, since only successful metal mines produced ore, but all mines, whether successful or not, produced waste. Knowing how specific historical mining technologies shaped the landscape and produced waste can illuminate important aspects of the mining landscape that have often been forgotten. By understanding how mine waste was produced, we are able to accurately and systematically compare how different phases of mining impacted the environment.

The type of waste that a mine produces depends on the technological system employed at the mine. If a mine is engaged in exploiting very high-grade ores, the waste produced will generally be deposited near the mine itself. If a mine is engaged in exploiting lowgrade ores, mine waste will still be found at the mine, but another form of waste, called tailings, will be found wherever that ore was processed. The location of mine waste reveals clues about a mine's history. Knowing where mine waste was dumped and how mine waste was produced illuminates the long history of a mining landscape and the technologies that were used to shape it. Waste is a ubiquitous feature within mining landscapes, found in abundance at both historical and active mining sites. While ore is shipped away from a mine, the waste a mine produces remains at, or near the mine itself. 
Long after a mine is shut down, abandoned, and forgotten, the waste the mine produced is often the last visible reminder of that site's industrial past.

This study shows that the technological shift to low-grade ore mining placed new demands on the environment, primarily around processing plants, which laundered millions of tons of tailings into lakes. Additionally, direct shipping ore mines produced significantly less mine waste than low-grade ore mines, and this waste was confined to the mines themselves, rarely encountered by the public outside of the active mining landscape. In contrast to direct shipping ores, low-grade ore processing delivered the legacies of mining waste into the backyards of communities.

This paper shows how the shift to low-grade iron ore mining created clusters of intensive mining and ore processing activity. The technological shift to low-grade ore mining converted what had once been seen as waste-the low-grade ore-into something of value, while creating vast new volumes of tailings. On the Mesabi Range today, over 125,000 acres of tailings, mine waste, and open pits suggest the enormous scale of low-grade iron ore mining's environmental footprint.

The mining and processing of low-grade ores has created global landscapes of mine waste. Yet much of this mine waste remains hidden. In recent memory, two of the largest human caused environmental disasters were the result of failed technological systems designed to contain tailings. With the onset of global climate change, failures at tailings basin, like the disasters recently seen at the Mount Polley mine and the Bento Rodriguez mine, are likely to increase (Kiernan, 2016). This paper adds a new methodological approach that policy makers can employ to identify and understand mine waste. Understanding where mine waste is located, and how it 
was created, can help the public and policy makers better manage and monitor these latent features for future generations living within these mining landscapes. 


\section{Acknowledgments:}

This work was supported by the National Science Foundation (Grant \#R56645, Toxic Mobilizations in Iron Mining Contamination). 


\section{Works Cited:}

Andrews, T.G., 2008. Killing for Coal: America's Deadliest Labor War. Harvard University Press, Cambridge.

Bastow, T.F., 1986. This Vast Pollution: United States of America V.

Reserve Mining Co. Green Fields Books, Washington D.C.

Bijker, W.E., Hughes, T.P., Pinch, T.J. (Eds.), 1987. The Social

Construction of Technological Systems: New Directions in the

Sociology and History of Technology. The MIT Press, Cambridge.

Birkinbine, J.L.W., 1919. Beneficiating Iron Ore. ABC Iron Steel 3rd Editio.

By the Way, 1914. . Eng. Min. J. 95, 293-294.

Coleraine District, Mesabi Range, 1907. . Min. World 26, 15-16.

Coons-Pacific Iron Ore Treatment Plant, 1953. . Ski. Min. Rev. 42.

Counselman, T.B., 1941. Beneficiating Minnesota Iron Ores. Min.

Metall. 405-406.

Cummins, A.B., Given, I.A., 1973. SME Mining Engineering Handbooks,

Vol. 1 \& 2. Port City Press, Baltimore.

Cunfer, G., 2008. Scaling the Dust Bowl, in: Knowles, A.K. (Ed), Placing

History: How Maps, Spatial Data, and GIS are Changing Historical

Scholarship. ESRI Press, Redlands, CA, 95-121

Curtis, K.A., 2013. Gambling on Ore: The Nature of Metal Mining in the United States, 1860-1910. University Press of Colorado, Boulder.

Davis, E.W., 1964. Pioneering With Taconite. Minnesota Historical Society, St. Paul.

de Kruiff, P., 1929. Seven Iron Men: The Merritts and the Discovery of the Mesabi Range. Harcourt, Brace and Co., New York.

Finger, T.D., 2013. Trading Spaces: Transferring Energy and Organizing Power in the Nineteenth-Century Atlantic Grain Trade, in: Jorgensen, D., Jorgensen, F.A., Pritchard, S.B. (Eds.), New Natures: Joining Environmental History with Science and 
Technology Studies. University of Pittsburgh Press, Pittsburgh, p. 292.

Finnegan, J.R.J., Mandel, J., 2014. Minnesota Taconite Workers Health Study.

Harrison, H.S., 1953. Where is the iron ore coming from? Anal. J. 9, 98101.

Hatcher, H., 1950. A Century of Iron and Men. The Bobbs-Merrill Co., Indianapolis.

Hatvany, M., 2014. Growth and Erosion: A Reflection on Salt Marsh Evolution in the St. Lawrence Estuary Using HGIS, in: Bonnell, J., Fortin, M. (Eds.), Historical GIS Research in Canada. University of Calgary Press, Calgary, 181-196.

Hovis, L., Mouat, J., 1996. Miners, Engineers, and the Transformation of Work in the Western Mining Industry, 1880-1930. Technol. Cult. 37, 429-456.

Hubbard, J., 1948. Spiral Concentration. Min. World 13, 41-44.

Hughes, T.P., 1983. Networks of Power: Electrification in Western Society, 1880-1930. John Hopkins University Press, Baltimore.

Hunt, M., 1951. Taconite: Iron Ore Bonanza. Steelways.

Keeling, A., Sandlos, J., 2015. Mining and Communities in Northern Canada: History, Politics, and Memory, in: Keeling, A., Sandlos, J. (Eds.), . University of Calgary Press, Calgary, p. 441.

Kiernan, P., 2016. Mining Dams Grow to Colossal Heights, and So Do the Risks. Wallstreet J.

Kohn, C.F., Specht, R.E., 1958. The Mining of Taconite, Lake Superior Iron District. Geogr. Rev. 48, 528-539.

Lafreniere, D., Gilliland, J., 2015. “All the World's a Stage”: A GIS Framework for Recreating Personal Time-Space from Qualitative and Quantitative Sources. Trans. in GIS. 19, 225-246.

Lampa, M.G., 2004. Minnesota's Iron Country. Lake Superior Port 102 
Cities, Duluth.

LeCain, T., 2009. Mass Destruction: The Men and Giant Mines that Wired America and Scared the Planet. Rutgers University Press, New Brunswick.

Manuel, J., 2015. Taconite Dreams: The Struggle to Sustain Mining on Minnesota's Iron Range, 1915-2000. University of Minnesota Press, Minneapolis.

Morse, K., 2003. The Nature of Gold: An Environmental History of the Klondike Gold Rush. University of Washington Press, Seattle.

Nashwauk..., 1958. . Ski. Min. Rev. XLVII, 3-5.

Parks, R.D., 1949. Examination and Valuation of Mineral Property, 3rd ed. Addison-Wesley Press, Cambridge.

Reuss, M., Cutcliffe, S.H. (Eds.), 2010. The Illusory Boundary. University of Virginia Press, Charlottesville.

Reynolds, T.S., Dawson, V.P., 2011. Iron Will: Cleveland-Cliffs and the Mining of Iron Ore, 1847-2006. Wayne State University, Detroit.

Sandlos, J., Keeling, A., 2013. Zombie Mines and the (Over)Burden of History. Solut. J. 4, 80-83.

Smith, D.A., 1993. Mining America: the Industry and the Environment, 1800-1980. University Press of Colorado, Niwot.

Spence, C.C., 1970. Mining Engineers \& The American West: The LaceBoot Brigade, 1849-1933. Yale University Press, New Haven and London.

Taggart, A.F., 1927. Handbook of Ore Dressing, 1st ed. John Wiley \& Sons, New York.

The Iron Ore Dilemma, 1945. . Fortune Mag.

Thistle, J., Langston, N., 2016. Entangled histories: Iron ore mining in

Canada and the United States. Extr. Ind. Soc. 3, 269-277. doi:10.1016/j.exis.2015.06.003

Thurman, W.L., 1992. Waste Dumps of the Mesabi Range: Heritage or 103 
Blight? St. Cloud State University.

Tupper, C.A., 1912. Ore-Washing Plant of the Wisconsin Steel Co. Min. Eng. World 37.

Walling, F.B., Otts, L.E., 1967. Water Requirements of the Iron and Steel Industry. Washington D.C.

Work on the Mesabi Range is Extensive, 1906. . Iron Trade Rev. XXXIX, 28-29.

Young, G.J., 1932. Elements of Mining. McGraw-Hill Book Co., New York. 


\title{
Chapter 3: A Spatial Evaluation of Historic Iron Mining Impacts on Current Impaired Waters in Lake Superior's Mesabi Range ${ }^{1}$
}

\begin{abstract}
:
This paper examines the water quality legacies of historic and current iron mining in the Mesabi Range, the most productive iron range in the history of North America, producing more than $42 \%$ of the world's iron ore in the 1950s. Between 1893 and 2016, 3.5 billion tonnes of iron ore were shipped from the Mesabi Range to steel plants throughout the world. We map historic sites and quantities of iron mining, ore processing, water use, and tailings deposition within subwatershed boundaries. We then map the locations of impaired lakes within HUC-12 subwatershed boundaries within the Mesabi Range, using government datasets created for US federal Clean Water Act reporting. Comparing watersheds with and without historic mining activity, watersheds with historic mining activity currently contain a greater percentage of impaired lakes than control watersheds within the same range. These results suggest that historic iron ore mining and processing in the Mesabi Range affected water quality on a landscape scale, and these legacies persist long after the mines have closed. This paper outlines a novel spatial approach that land managers and policy makers can apply to other landscapes to assess the effects of past mining activity on watershed health.
\end{abstract}

${ }^{1}$ This chapter was submitted to Ambio: A Journal of the Human Environment, as: John Baeten, Nancy Langston, Don Lafreniere, A Spatial Evaluation of Historic Iron Mining Impacts on Current Impaired Waters in Lake Superior's Mesabi Range. 


\section{Introduction:}

Water contamination concerns accompany current heavy metal and coal mines across the globe (Cherry et al. 2001; Johnson and Hallberg 2005; Bernhardt et al. 2012; Byrne et al. 2012; McGarvey and Johnston 2013). Pollutant discharge from mine wastes highlights the complex physical character these pollutants possess as they move from ground-based to water or airborne contaminants. The latter types, categorized as secondary or tertiary contamination, are the most challenging to manage and pose the greatest threat to human health (Moore and Luoma 1990). Mine pollutants have the potential to alter the geochemistry of watersheds, especially when they are disturbed by hydrological activity such as flooding, which can produce a massive footprint of toxic legacies (Hunerlach et al. 1999; Grosbois et al. 2012; Moore and Langer 2012). Fluvial transport of mine waste through watersheds and the spread of heavy metal contaminants from abandoned mine sites and waste dumps remain pressing global concerns.(Macklin et al. 1997; Miller 1997; MacKenzie and Pulford 2002; James and Marcus 2006; Angelstam et al. 2013; Singer et al. 2013; Keeling and Sandlos 2015).

Mines can alter geomorphic systems and hydrological cycles during their operation and abandonment, dewatering, ore processing, and post-mining flooding (Younger and Wolkersdorfer 2004; Savage et al. 2010; Ross et al. 2016). Mine-pit lakes have emerged as a recent focus of water quality concern. When subsurface and open-pit mines are closed, the dewatering pumps are typically stopped. Groundwater then floods these former mines, creating mine-pit lakes which can be contaminated with a variety of heavy metals (Axler et al. 1996; Axler, Richard et al. 1998). Additionally, some mining sites, including some within the Mesabi Range such as the Dunka mine, contain metal sulfides such as pyrites in the surrounding rock and overburden. After 
those mines have been abandoned and pumping has stopped, exposure of the sulfides to air and water can create acidic drainage which decreases stream $\mathrm{pH}$ and may also release lead, arsenic, aluminum, manganese, and nickel into watersheds. Such sites can require perpetual care (Pellicori et al. 2005; LeCain 2009).

Ore processing, not just mining, also has the potential to impact watersheds, most notably from the disposal into surface waters of tailings, a finely-ground form of mine waste. Tailings can damage fisheries, affect downstream agriculture, and mobilize toxic chemicals into community water sources (Quivik 1998; Sullivan 2014; Manuel 2015).

Since the 1977 Surface Mining and Reclamation Act, mining companies have been required to reclaim US mine sites when production stops. Those efforts are effective at removing debris and revegetating sites, but less effective at halting acid drainage. Landscape-scale impacts produced from mining, both chemical and physical, may resist reclamation efforts, leading to the slow regrowth of vegetation on reclaimed mine lands and tailings piles (LeClerc and Wiersma 2017). Additionally, no federal law requires remediation of mines closed before 1977, and those mines, processing facilities, and tailings piles continue to release pollutants into watersheds. Legacy pollutants from mines abandoned before 1977 may persist within river, steam, and lake sediments.(Limerick et al. 2005; Worrall et al. 2009; Bird 2016).

Studies of historic mining impacts on current environmental condition have typically focused on contaminated sediments located downstream of copper, silver, and gold mining and ore processing sites (Hudson-Edwards et al. 1997; Thomas et al. 2002; Church et al. 2007; Haunch and MacDonald 2011; Haunch 2013; Walker et al. 2015). Fewer studies have examined the historic water quality legacies of iron 
mining, which has been portrayed as less toxic because cyanide and mercury were not used in processing (Langston 2017). Yet the mining and processing of iron ores in the Lake Superior region have produced environmental problems including acid mine drainage when pyrites were present, the release of asbestiform fibers from some taconite tailings, and the production of atmospheric mercury from taconite beneficiation (Langston 2017).

This paper uses methodologies found commonly within the discipline of historical GIS such as spatializing historical documents, record linking across datasets, and comparing historical environments and landscapes to modern ones (Cunfer 2008; Gutmann et al. 2016; Van Allen and Lafreniere 2016; Clifford 2017). We extend these disciplinary approaches by using historical sources to understand the past and to inform present day understandings of mining impacts on the environment. We also suggest two policy changes to improve water quality monitoring in the mining region.

Using publicly available water quality databases from the Minnesota Pollution Control Agency and historical mining datasets derived from archives, this paper analyzes the impacts that past iron mining have had on the watersheds of Lake Superior's Mesabi Range, asking whether the influence of historic iron mining on water quality can still be detected today. We ask if watersheds with historic mining activity have different water quality than watersheds without historic mining activity, and if those effects differ by mining technology. Finally we present a novel historical and spatial approach that can be applied to other landscapes to assess the impacts that mining has had on watersheds, suggesting that historical datasets can be used to inform current environmental science and policy. 


\section{The Mesabi Range:}

The Mesabi Range, North America's most productive iron mining district, stretches across the upper reaches of two major watersheds. The first watershed is the St. Louis River flowing into Lake Superior, the world's largest lake by surface area and headwaters of the Great Lakes, which contain 21\% of the world's freshwater (MacFarlane 2016). The second watershed contains the headwaters of the Mississippi River, North America's largest drainage basin (Figure 3.1). More than 400 mines operated on the Mesabi Range after 1893, producing more than 3.5 billion tonnes of iron ore (Baeten et al.). Each of these mines had the potential to affect water quality, yet as mining technologies shifted, the potential impact of iron mining and processing may have shifted as well. The iron mines of the Mesabi Range and the broader Lake Superior Iron Ore District were globally significant, serving as the primary producer of global iron ore for more than a half-century, and providing nearly half the world's supply of iron ore during the years following World War II (Forbes 1953). But as these Lake Superior ore bodies became depleted and iron mines developed elsewhere, the global contribution of the region declined. Today, the Mesabi Range still accounts for nearly 99\% of United States iron production, but only $2 \%$ of global production, a marked decline that became pronounced in the 1980s (Yellishetty et al. 2010). While reclamation efforts concerned with rehabilitating the post-mining landscape have removed much of the mining infrastructure (such as processing plants) from the landscape, potentially toxic legacies of mining remain in tailings ponds, mine-waste dumps, and lake beds. 


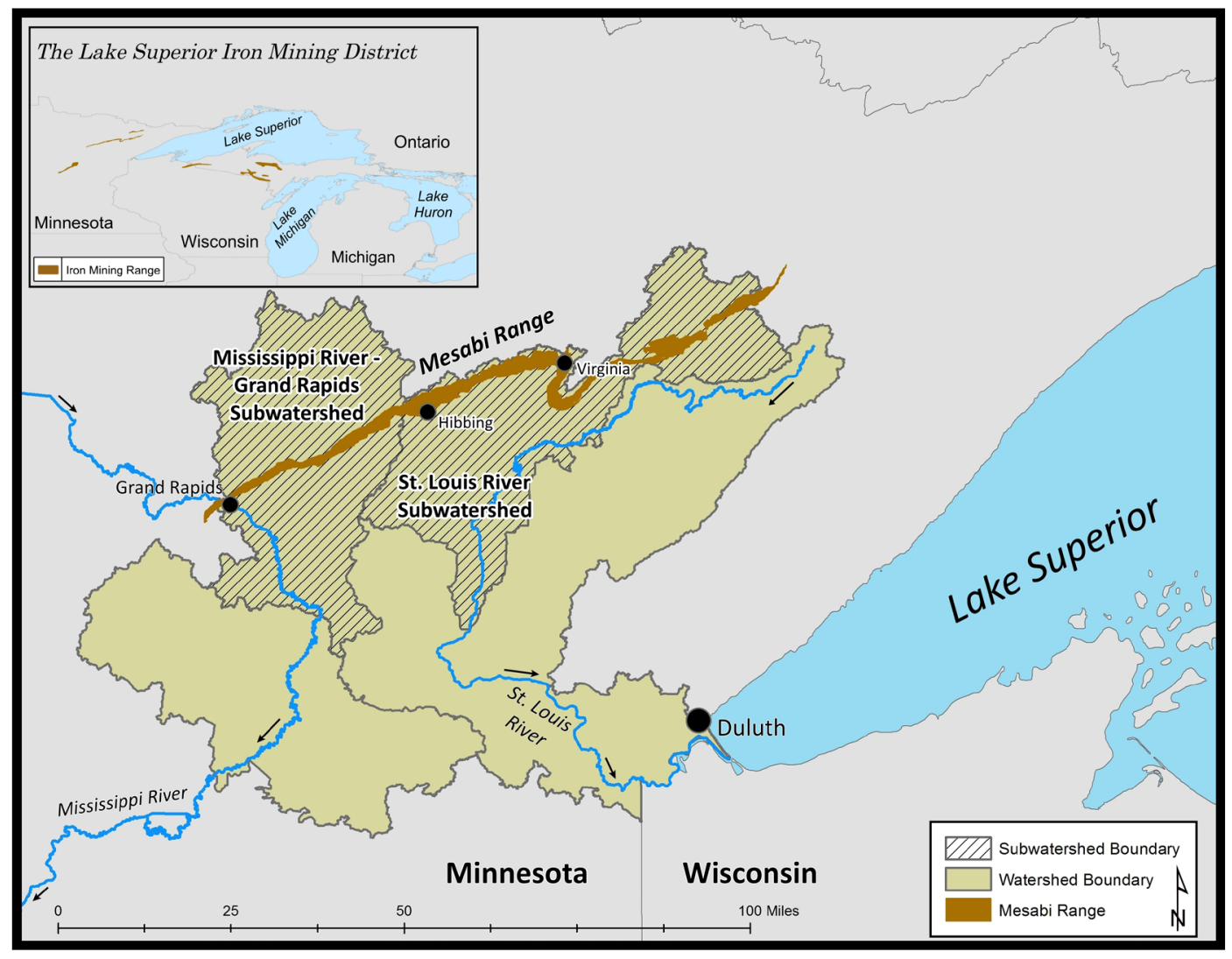

Figure 3.1: Watersheds (HUC-08) of the Mesabi Iron Range. The subwatersheds (HUC-10) are those portions of the watersheds located within the mining region.

\section{A. Mining Technologies}

Direct shipping ore mines 1893-1970s:

The focus of metal mining is the profitable extraction of ore, an economic term used to describe a metalliferous deposit. In the Mesabi Range three types of ore were mined: direct- shipping ore, washable ore, and taconite (Taggart 1927). Beginning in 1893, iron mines on the Mesabi Range targeted rich deposits of hematite iron ore, mineral bodies containing upwards of 70\% iron (Davis 1964). These high-grade deposits contained what were called direct- shipping ores that could be dug from the earth, loaded onto a rail system, and shipped directly to the lower Great Lakes for smelting. Direct shipping ore mining in 
the Mesabi Range involved both underground and open-pit mines. Both types of mines filled with water when the elevation of the active mine dropped below groundwater elevation, which meant that engineers needed to dewater the mines with pumps and discharge the effluent into neighboring streams and lakes. Dewatering a mine had several possible effects on water quality (Zellie 2005). Mine dewatering might lower the water table in the local area, which could dry up some small streams. Mine dewatering also created effluent discharges that could be contaminated with heavy metals and industrial refuse from the mining process.

Deforestation associated with the mining of direct shipping ores also had the potential to affect water quality. Underground mines required timbers to support subterranean workings; open pit mines required clearing at the local site; and railway construction required harvests of local forests for crossties. Construction of open-pit direct shipping ore mines required the removal of over-burden, consisting of all vegetation on the site and up to 132 meters of soil and rock (Young 1932). No state laws required restoration of such sites until 1969, so the deforestation and soil disturbance produced from direct shipping ore mines likely led to increased runoff and siltation into waterbodies (Mineland Reclamation: Minnesota's Program 1988).

\section{Washable Ores 1910-1980s:}

Mesabi Range low-grade iron ore mining began in 1910, with the extraction and processing of silica-laden deposits called washable ores (Van Barneveld 1913). Washable ores contained about 40\% iron upon extraction, a percentage of iron that was too low to send directly to smelters. Washable ore mines were primarily open-pit excavations, a mining method commonly employed for the extraction of lower- 
grade ores (Young 1932). To create a merchantable product, before shipping, mining companies needed to increase the percentage of iron in these washable ores, achieved through a process called beneficiation. Mining companies constructed beneficiation plants at a distance of up to eight kilometers from the mine and used mechanical processes to separate the waste from the ore and concentrate the iron content.

In the process, beneficiation plants consumed on average 3,400 liters of water and created on average 1.5 metric tonnes of tailings for each metric tonne of iron produced (Baeten et al.). Washable ore beneficiation plants depended on local surface water sources for two main purposes. First, the surface waters themselves were essential for iron ore concentration; and second, surface waters provided mining companies with a sink to deposit the continual flow of tailings produced during ore concentration. Throughout the beneficiation process, water was introduced to the ore as it traveled across screens and classifiers, riffled tables, and through mechanisms designed to capture heavy material and release the less dense and lighter material as tailings.

Owing to their need for water, mining companies constructed these beneficiation plants near lakes, from which they drew water to use for ore concentration. For a low-grade ore mine to be profitable, an ample supply of water was nearly as important as a plentiful ore deposit. The smallest of washable ore beneficiation plants required a constant water supply of "at least 1200 gallons of water per minute" [4,542 liters], while larger plants required significantly more water (Iron Ore Concentrating Plants of Minnesota 1920). Water helped the material move through the beneficiation facility, aided in separating the ore from the mineral waste, and ultimately transported tailings to 
deposition sites, which were initially lakes and later constructed tailings basins (Hubbard 1948).

\section{Taconite processing 1956-2016:}

Beginning in 1956, the focus of mining companies in the Mesabi Range shifted to an even lower grade of iron ore called taconite. A magnetite ore, taconite contained between 15 and 30\% iron, the lowest percentage of iron and the highest percent of waste among Mesabi Range ores. Beneficiation of these ores occurred at taconite concentrators, where ore was crushed and finely ground. During taconite concentration, water was introduced to the ore to separate out waste and limit the quantity of dust produced (Kohn and Specht 1958). Next, the slurry of magnetite, water and waste was fed into magnetic separators and gravity classifiers, where magnets attracted the iron while the water and tailings continued to travel through the facility (Davis 1964). After magnetic concentration, the taconite concentrates were dewatered and dried, then combined with clay to create small spherical pellets (Hunt 1951). The tailings produced from taconite ores, like those produced from washable ores, were pumped away from the processing plants and deposited either back into lakes or into constructed tailings basins. However, due to the more intensive processing that occurred at taconite concentrators, taconite tailings were much finer than washable ore tailings, allowing for easier mobilization within waterbodies. Each metric tonne of taconite pellets shipped off the range resulted in the production of three tonnes of tailings and the consumption of 22,700 liters of water (Cummins and Given 1973; Technical Resource Document: Extraction and Beneficiation of Ores and Minerals 1994). 


\section{Methods:}

\section{A. Mapping Watershed Boundaries}

This study's analysis of iron mining's impacts on the watersheds of the Mesabi Range began with locating the boundaries of HUC-12 subwatersheds. The US Geological Survey (USGS) uses Hydrological Unit Codes (HUC) to delineate watershed boundaries.(Seaber, Paul et al. 1994) Hydrologic Unit Codes range from 2 to 12-digits, and the smaller the HUC code digit, the larger the watershed. The national Watershed Boundary Dataset (WBD) provided by the USDA Geospatial Data Gateway was accessed for this analysis, and individual watersheds delineated by the Minnesota Department of Natural Resources were identified and isolated (The 8, 10, and 12 hydrologic unit boundaries for Minnesota 2008; Watershed Boundary Dataset (WBD)). The HUC-12 scale was used because it allowed enough spatial resolution to distinguish between watersheds with differing levels of historic mining and processing activity. The intensity of mining that occurred within each HUC-12 that surrounded the Mesabi Range was quantified by calculating the tonnes of direct shipping ore mined, tonnes of washable ore mined and processed, tonnes of taconite ore mined and processed, tonnes of tailings deposited, and gallons of water consumed by processing plants (Baeten et al.).

Mining in the Mesabi Range was confined to the Upper Mississippi-Grand Rapids and St. Louis River watersheds, which each contain smaller HUC-12 subwatersheds, ranging in size from 10,00040,000 acres. A subset of HUC-12 subwatersheds that were located within stream reaches of mining activity from the Mesabi Range were selected for analysis consisting of 25 HUC-12 subwatersheds in the Upper Mississippi Grand Rapids watershed, and 26 in the St. Louis River watershed. Mining activity in the Mesabi Range was confined to 21 of the HUC-12 subwatersheds, while the remaining 30 functioned 
as . units for the analysis. These 51 HUC-12 subwatersheds were isolated in a historical GIS (HGIS) and their boundaries were used as the geographic basis for the analysis of mining impacts (see Figure 2 below).

The location of mine-pit lakes within each HUC-12 subwatershed of the study area were also identified. Mine-pit lakes are historical mines that were abandoned and allowed to fill with water, ranging in size from 1 acre to 1,055 acres. Hydrological datasets managed by the Minnesota Department of Natural Resources were used to identify and isolate the former mine-pit lakes from naturally occurring surface waters.

\section{B. Mapping Mining Intensity}

The sites of all iron mines and processing plants, and the visible extent of mine waste were mapped to quantify the level of historic mining intensity within each HUC-12. Mine locational data was acquired in a shapefile format from government-managed geospatial clearinghouses, such as the USGS (Mineral Resources Data System 2005). The analysis of both aerial imagery and LiDAR data (one-meter digital elevation models) provided by the Minnesota Department of Natural Resources was used to populate the waste footprint (LiDAR Elevation, Arrowhead Region, NE Minnesota, 2011; LiDAR Elevation, Central Lakes Region, Minnesota, 2012). The visible waste footprint, which includes open-pit mines, tailings piles, and mine waste, was manually digitized and the total area calculated, creating a dataset that represents the current extent of barren lands associated with past mining activity.

To calculate the quantities of ore mined, waste produced, and water consumed over the history of each mine and processing plant, annual iron ore shipment statistics were entered into our HGIS. These 
data were recorded by mines and published in trade journals and archives. Mine production statistics from a 114-year period $(5,972$ entries from 1898-2012) were entered into the HGIS (Table 3.1) (The Lake Superior District 1920). Each mine was then coded as one of the three types of ore extracted: direct-shipping ore, washable ore, or taconite.

Table 3.1: Source materials used in constructing the HGIS

\begin{tabular}{|c|c|c|}
\hline Archival Source & $\begin{array}{l}\text { Historic Mine } \\
\text { Production Data }\end{array}$ & Years \\
\hline Iron Trade Review & $\begin{array}{c}2,550 \text { Annual } \\
\text { Production Entries }\end{array}$ & $1898-1930$ \\
\hline Steel & $\begin{array}{l}913 \text { Annual Production } \\
\text { Entries }\end{array}$ & $1931-1944$ \\
\hline Skillings' Mining Review & $\begin{array}{c}\text { 2,440 Annual } \\
\text { Production Entries }\end{array}$ & $1944-1981$ \\
\hline $\begin{array}{l}\text { Mining Tax Guide (MN Dept. } \\
\text { Revenue) }\end{array}$ & $\begin{array}{l}69 \text { Annual Production } \\
\text { Entries }\end{array}$ & $2011 / 2015$ \\
\hline Archival Source & $\begin{array}{l}\text { Beneficiation Plant } \\
\text { Locational Data }\end{array}$ & Years \\
\hline $\begin{array}{l}\text { Historical Trade Journals } \\
\text { Maps/USGS Mineral Reports }\end{array}$ & $\begin{array}{l}88 \text { Beneficiation Plant } \\
\text { Shapefile Points }\end{array}$ & $1910-1980$ \\
\hline Government Database & Geospatial Data & Type \\
\hline $\begin{array}{c}\text { USGS Mineral Resource Data } \\
\text { System }\end{array}$ & 403 Shapefile Points & $\begin{array}{l}\text { Mine Locational } \\
\text { Data }\end{array}$ \\
\hline $\begin{array}{l}\text { USDA Geospatial Data } \\
\text { Gateway }\end{array}$ & $\begin{array}{l}\text { 3,901 Shapefile } \\
\text { Polygons }\end{array}$ & $\begin{array}{c}\text { Watershed } \\
\text { Boundary Dataset: } \\
\text { HUC-12 }\end{array}$ \\
\hline $\begin{array}{l}\text { Minnesota Geospatial } \\
\text { Commons: Minnesota } \\
\text { Pollution Control Agency }\end{array}$ & $\begin{array}{l}\text { 3,840 Shapefile } \\
\text { Polygons }\end{array}$ & $\begin{array}{l}\text { Impaired Waters } \\
\text { Data: Lakes }\end{array}$ \\
\hline
\end{tabular}

To quantify water consumption and tailings production for each HUC-12 subwastershed, the locations of beneficiation facilities were located, mapped, and linked to source mines. This process required 
the analysis of archival records, historic maps, and aerial imagery, together, to determine the locations of beneficiation facilities, the companies that operated them, and the years of operation. The data was manually geocoded and record linked within the HGIS, providing the locations of both mines and processing plants, as well as iron ore production totals from direct shipping ore mines, washable ore mines, and taconite mines, for every year from 1898-2012.

To determine water usage and tailings production, concentration ratios were then calculated using archival sources, such as the Iron Trade and Review, a trade journal containing annual production reports from iron ore concentrators. Because water acquisition was essential at beneficiation plants, companies tracked the quantity of water consumed in different stages of production, allowing the calculation of average water consumption and tailings production during beneficiation for washable ore versus taconite processing. . On average, washable ore processing plants consumed 3,400 liters of water for every tonne of ore processed, while taconite processing plants consumed on average 20,000 liters (Taggart 1927). Washable ores processing plants produced on average 1.4 tonnes of tailings for every tonne of washable ore concentrates produced, while taconite plants produced on average 2.7 tonnes of tailings for every tonne of taconite concentrates produced. The increase in water consumption and tailings production seen at taconite beneficiation plants was due to the physical differences between taconite ores and washable ores. Taconite ores required much more intensive processing, due to both their lower concentration of iron, and the compact nature of the mineral deposit (Davis 1964). This meant that compared to washable ores, which underwent a relatively simple classification process during concentration, taconite ores were subjected to a much more intensive beneficiation process, including 
crushing and fine grinding, which required more water and also produced more tailings. This more intensive beneficiation process made taconite tailings much finer than washable ore tailings, which allowed taconite tailings to migrate more easily and at further distances than washable ore tailings (Baeten et al.).

To calculate the average amount of tailings produced and water consumed during iron ore concentration at individual processing plants, the ore production totals from mines that produced low-grade ores were record linked to the beneficiation plants where the ore was concentrated. These production totals were then entered into these concentration formulas to generate annual water consumption and tailings production from each beneficiation plant. For instance, the Quinn-Harrison washable ore concentrator in the Mesabi Range processed 15 million tonnes of washable ore in 1925. Assuming that this washable ore concentrator consumed 3,400 liters of water for every tonne of ore processed, this plant would have consumed 51 billion liters of water in 1925 alone.

To calculate mining intensity within each HUC-12 subwatershed, the mapped locations of mines, beneficiation plants, water withdrawals, and tailing production were spatially joined and aggregated to each individual HUC-12 subwatershed for each year of mining activity. This provided the total tonnes of direct shipping ore, washable ore, and taconite mined, as well as the total tonnes of washable ore concentrated, and the total tonnes of taconite ore concentrated at beneficiation plants for each watershed during each year. For each HUC-12 subwatershed, the total amount of tailings produced and water consumed from both washable ore and taconite ore beneficiation plants were calculated annually for the years 19102012. The quantities of ore mined in each subwatershed, the types of mining technology employed, the quantity of tailings deposited, and 
water used can be seen in the chloropleth maps in Figures 3.3 and 3.4 below.

\section{Categorizing Impaired Waters vs. Non-Impaired Waters}

The MPCA estimates that about 40\% of Minnesota's waters (including lakes and streams) fail to meet water quality standards outlined by the Clean Water Act (Minnesota's Impaired Waters List 2017). Many factors influence water quality, including agricultural runoff, combined sewage overflows from some municipalities, and impermeable surfaces in developed areas. Agriculture in the state is a particularly important source of water quality concerns. However, within northeastern Minnesota where the Mesabi Range is located, agriculture and urban development are less significant than in other parts of the state, primarily because populations are lower and large agricultural operations are rare in this part of the state due to the climate, soil, and topography (Minnesota Pollution Control Agency 2008).

As part of the state's Clean Water Act reporting, the MPCA assesses the water quality of a certain fraction of stream reaches and lakes within Minnesota. The Clean Water Act defines a waterbody as impaired if it fails to meet a water quality standard set by the state, usually related to a beneficial use such as swimming, drinking, or fishing (Water Quality Standards 2017). MPCA staff, agency partners, and volunteers collect environmental data on selected lakes and streams across the state over a ten year period (Anderson et al. 2014; Anderson 2016). Beginning in 2008, the MPCA introduced a watershed approach, assessing lake and stream chemistry and biology within eight of the state's 80 major watersheds per year, so that each watershed will be assessed once a decade (Anderson and Martin 2015). The MPCA aimed to monitor and assess all lakes larger than 
500 acres and at least half the smaller lakes (Lakes and water quality 2017).

MPCA scientists, in collaboration with state and federal agency personnel, collect water samples from individual waterbodies, called "assessment units", which consist of stream reaches, lakes, and wetlands (Anderson 2016). Samples are assessed for physical, chemical and biological parameters including fish bioassessments, macroinvertabrates, turbidity, mercury, total phosphorus, PCBs and other synthetic chemicals, fecal coliform, and low dissolved oxygen. No stream reach or lake in the Mesabi Range had sufficient data to assess all these parameters, however. For example, for 34 stream reaches in our sample, 21 possible parameters were listed, but $82 \%$ of them were not assessed or had insufficient data for the state to report the data. In addition to reporting on individual water quality measures, the MPCA staff create a single category for each water body or stream reach assessed: healthy, possibly healthy, or impaired. Because of missing data, not a single stream reach or lake in the Mesabi Range has been categorized as "healthy." Instead, most have been categorized as either "impaired" (when some measured parameters fail to meet standards) versus "possibly healthy," which is used when measured parameters meet standards, but some key parameters were not measured (Water Quality: Describing Water Quality 2017).

Gaps in the data on individual water quality parameters meant that this study had to rely upon the MPCA's summary categories for each waterbody (Impaired Lakes 2012 2012). The MPCA has assessed $40 \%$ of the total lake acreage within the Mesabi Range itself. Because of the agency's emphasis upon larger lakes, only $15 \%$ of lakes within the Mesabi Range have been included in that assessment. Of 251 lakes created by former mine pits, only $5 \%$ have been included in the 
assessment. Choropleth maps were used to identify the spatial variation in the proportion of impaired lakes, and the location of historic mining intensity, within each HUC-12 subwatershed across the study area.

Within the 51 HUC-12 subwatersheds in this study's analysis area, 2,509 lakes have been identified totaling 28,707 hectares of lake surface area. The MPCA assessed 187 of these lakes, categorizing 110 of them as impaired (9,607 hectares) and 77 (3,793 hectares) as possibly healthy (i.e., no impairments of beneficial uses, but not all uses assessed). This study excluded the other 2322 lakes that had not been assessed (mostly lakes smaller than $1 \mathrm{ha}$ ), and those that did not contain sufficient data for the MPCA to categorize as impaired or possibly healthy. Within each HUC-12 subwatershed, the acreage, location, and water quality condition category of each assessed lake were recorded. Then, for each HUC-12 subwatershed, the total acreages of lakes that were categorized by the MPCA as "possibly healthy" vs. "impaired" were summed and the proportion of impaired lake acreage calculated (Impaired Lakes 2012 2012). The presence or absence of each type of historic mining was then recorded for each HUC-12 subwatershed. The proportion of impaired waters in HUC-12 subwatersheds with historic mining were compared to HUC-12 subwatersheds without historic mining, using Student t-tests.

\section{Results:}

Historic mining and ore processing were concentrated in 20 of the 51 HUC-12 subwatersheds across the Mesabi Range (Figure 3.2). Waste from mining, however, is present in 29 of 51 HUC-12 subwatersheds, demonstrating that the waste footprint is larger than the mine and processing plant locations would suggest. Within the 
immediate extent of the Mesabi Range's iron formation, 137 natural lakes now exist (643 hectares), compared to 251 mine-pit lakes (4,228 hectares) (Figure 2). 87\% of lake acreage within the Mesabi Range consists of former mine pits, rather than natural lakes.

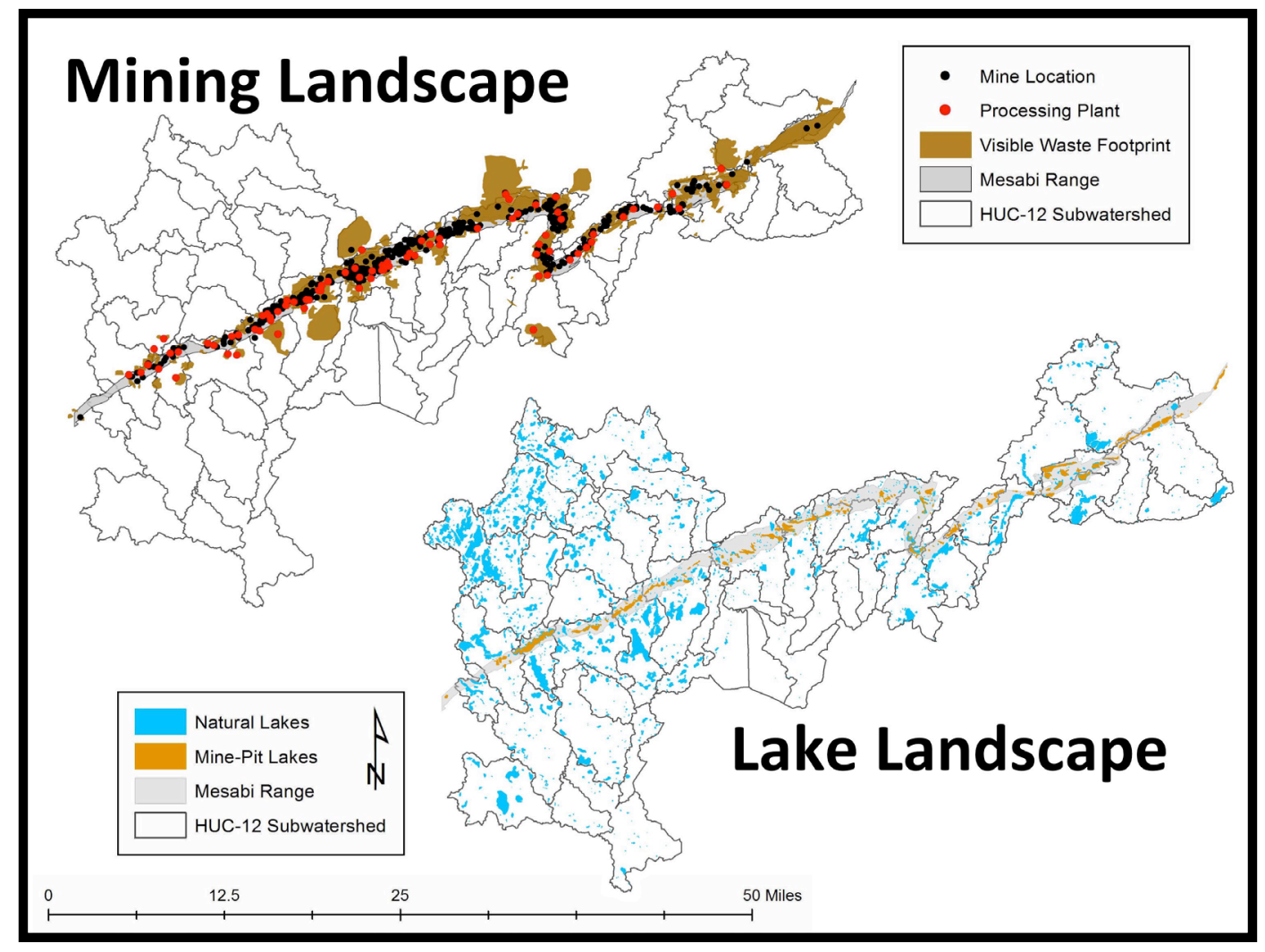

Figure 3.2: Overview of the mining landscape (mine locations, processing plants, and visible waste footprint) and lake landscape within HUC-12 subwatersheds.

Over the 114 years of the study sample, direct shipping ores were mined in 17 of the HUC-12 subwatersheds, while washable ores were mined in 16 subwatersheds, and taconite ores in 9 subwatersheds (Figure 3.3). More than one type of mining technology occurred in 15 of the 20 subwatershed that experienced mining activity. HUC-12 subwatersheds where direct shipping ore mining occurred averaged a tonnage of 48.9 millions tonnes per watershed, while those that experienced washable ore mining averaged 85.7 
million tonnes, and HUC-12 subwatersheds that experienced taconite mining average 186.3 millions tonnes. Although taconite mines produced the largest average of ore mined per individual watershed and the largest total tonnage of the three mining technologies, taconite mines were located in the fewest watersheds, suggesting that taconite mining had more concentrated impacts.

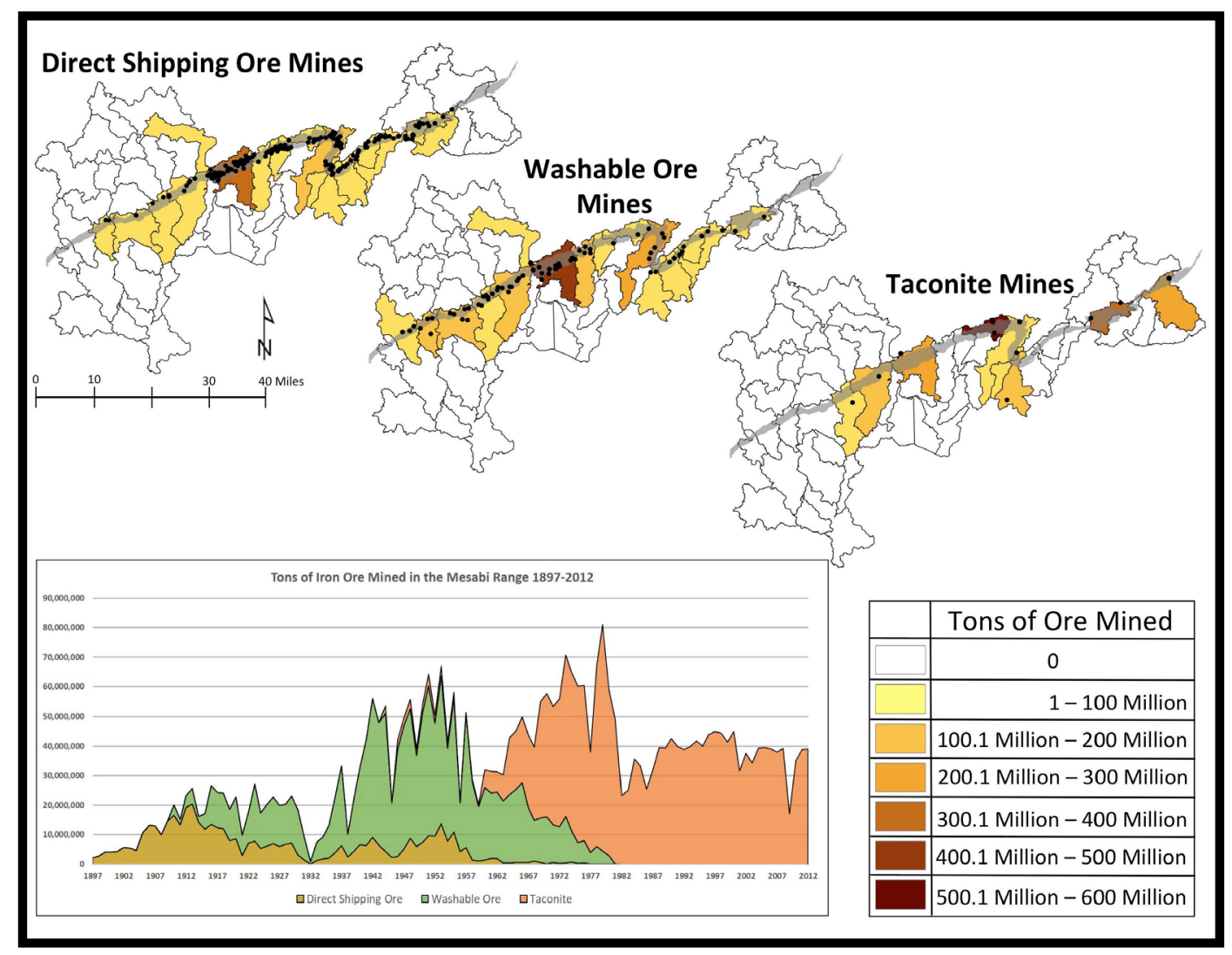

Figure 3.3: Choropleth map showing the intensity of mining (100-million ton intervals) within the HUC-12 subwatersheds as produced by a specific mining technology from 1898-2012.

Water consumption and tailings by different mining types are mapped in Figure 3.4. The extent of washable ores processing was more widespread than taconite processing, occurring in more watersheds and at nearly ten times as many processing plants. The intensity of water withdrawals and tailings disposals into watersheds 
from taconite beneficiation was more intensive than at washable ore plants.

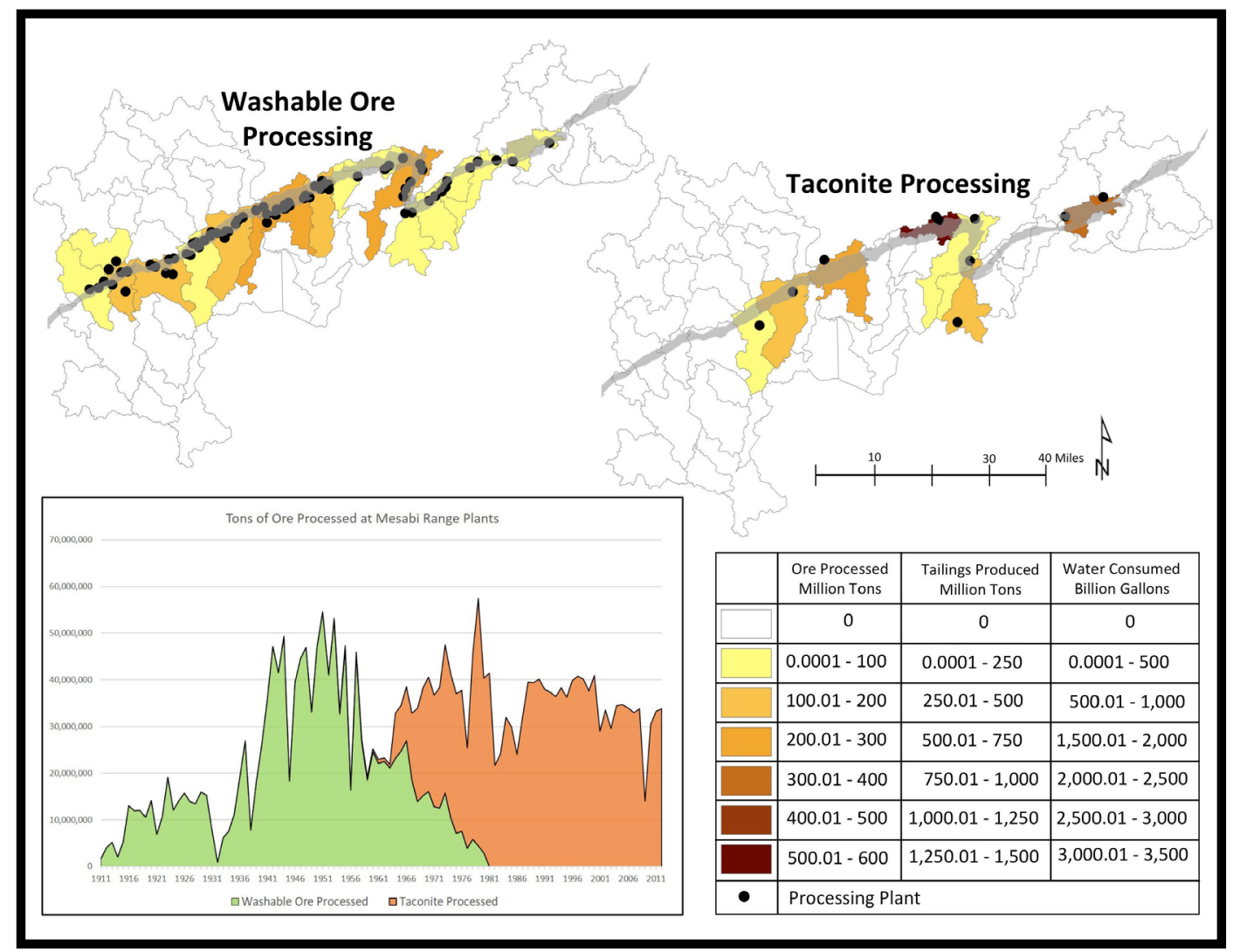

Figure 3.4: Intensity of Washable Ore Processing and Taconite Processing within the HUC-12 Subwatersheds

The percentage of impaired lake acreage within each individual HUC-12 subwatershed and the intensity of different mining technologies are shown in Figure 3.5. HUC-12 subwatersheds that are located within the immediate extent of the Mesabi Range have a higher percent of impaired lake acreage than the units located outside of the Mesabi Range. Similarly, watersheds with greater historic mining intensity coincide spatially with greater proportion of impaired waters. 
The intensity of ore processing as it compares to impaired lake acreage is mapped in Figure 3.6. HUC-12 subwatersheds with greater historic ore processing show a greater proportion of impaired waters.

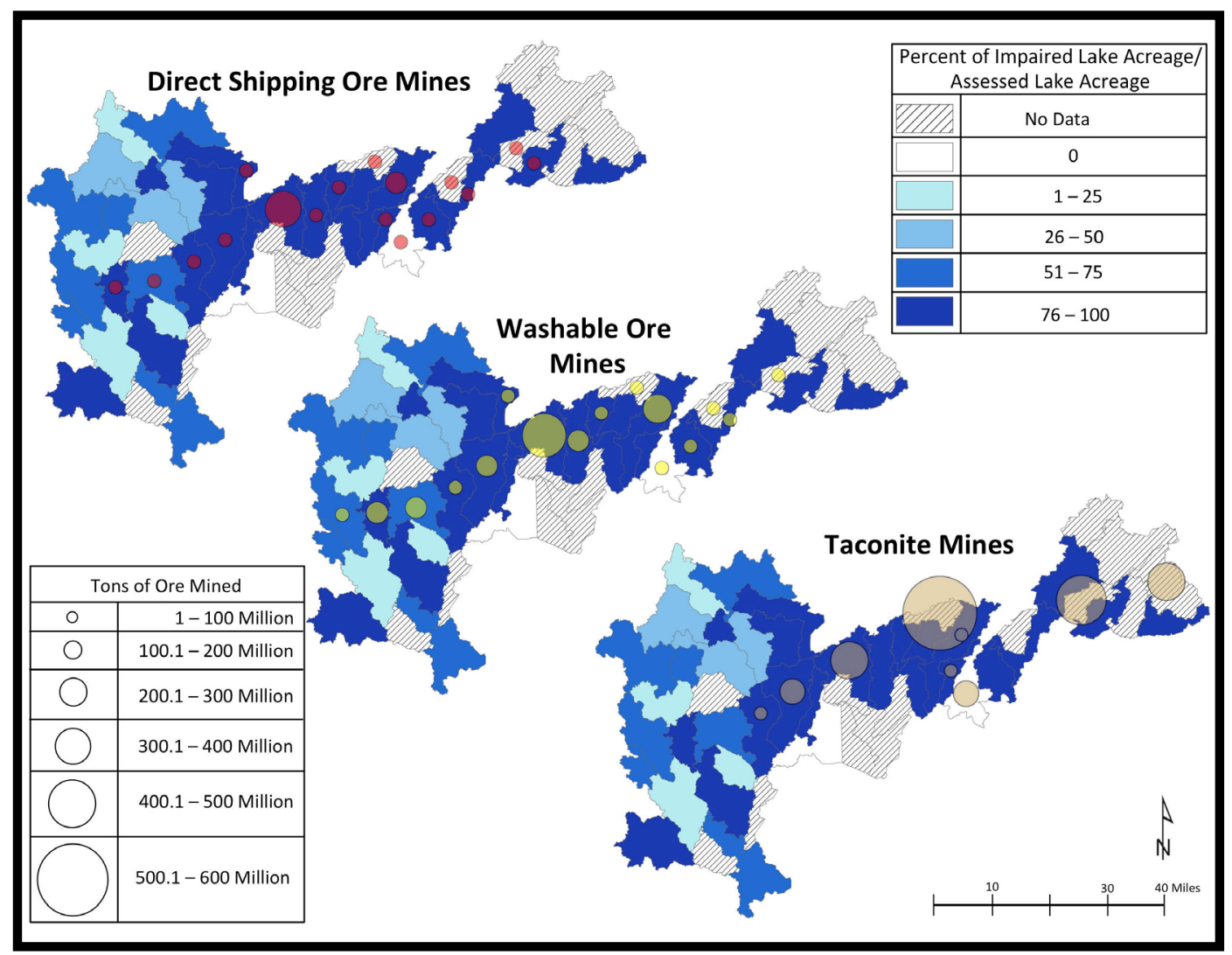

Figure 3.5: Percent of impaired lake acreage compared with mining intensity. Graduated symbols represent total tons of ore mined within each subwatershed. 


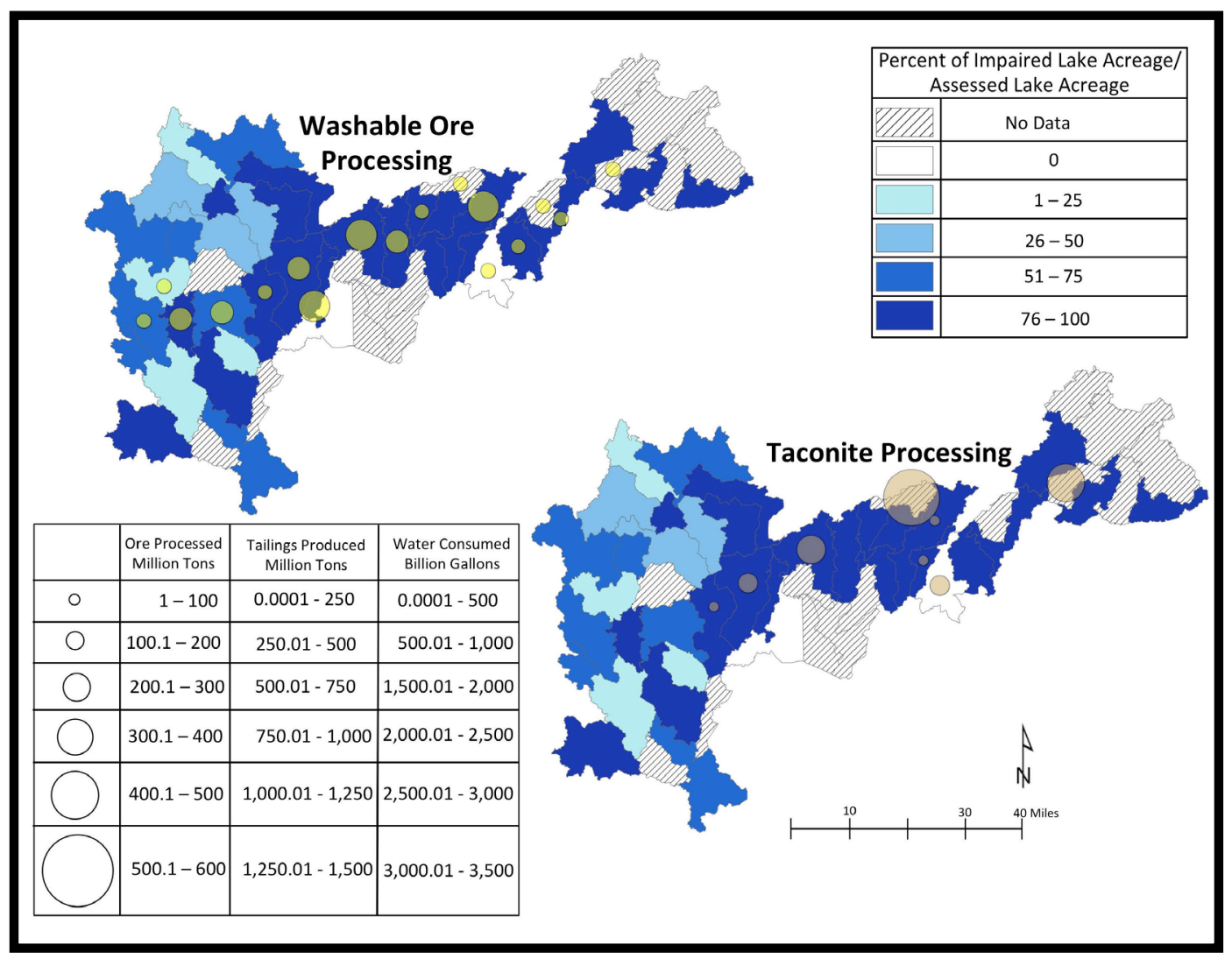

Figure 3.6: Percent of impaired lake acreage compared with intensity of ore processing, tailings production, and water consumption.

Graduated symbols represent total amount of ore processed within each subwatershed.

HUC-12 subwatersheds with a history of direct shipping ore mining have a higher proportion of impaired lakes than watersheds without a history of mining (Table $3.2, t(36)=2.05, p<.05$ ). Because six HUC-12 subwatersheds with historic direct shipping ore mining also contain modern taconite mining, the analysis was repeated using only those HUC-12 subwatersheds without modern taconite mining to control for possible effects of modern mining on water quality. The effect for direct shipping ore mining remained, although with the smaller sample size, the effect was not quite significant at the $\mathrm{p}<0.05$ level, with $t(30)=2.00, \mathrm{p}=.055$. 
HUC-12 subwatersheds with a history of washable ore and taconite mining and processing also have a higher proportion of impaired lakes than those without such mining, but these relationships are not statistically significant (Table 3.2). However, several of the HUC-12 subwatersheds that experienced the greatest intensity of both washable ore and taconite mining and processing were also watersheds where no lakes were assessed for water quality, making it difficult to evaluate these results (Figure 4.5 and 4.6).

Table 3.2: Mean proportion impaired lakes in HUC-12 subwatersheds with different types of historic mining activity.

\begin{tabular}{|l|c|c|c|c|}
\hline \hline \multicolumn{1}{|c|}{ Mining Activity } & $\begin{array}{c}\text { Proportion } \\
\text { Impaired } \\
\text { Lakes }\end{array}$ & $\begin{array}{c}\text { Standard } \\
\text { Deviation }\end{array}$ & $\begin{array}{c}\text { t-test } \\
\text { statistic }\end{array}$ & p value \\
\hline $\begin{array}{l}\text { Watersheds without direct shipping } \\
\text { ore mining n=24 }\end{array}$ & 0.63 & 0.156 & $\mathrm{t}(36)=2.05$ & 0.048 \\
\hline $\begin{array}{l}\text { Watersheds with direct shipping } \\
\text { ore mining n=14 }\end{array}$ & 0.863 & 0.162 & & \\
\hline $\begin{array}{l}\text { Watersheds without washable ore } \\
\text { activity n=23 }\end{array}$ & 0.665 & 0.16 & $\mathrm{t}(36)=1.1$ & 0.3 \\
\hline $\begin{array}{l}\text { Watersheds with washable ore } \\
\text { activity n=15 }\end{array}$ & 0.794 & 0.18 & & \\
\hline \hline $\begin{array}{l}\text { Watersheds without taconite } \\
\text { activity n=32 }\end{array}$ & 0.697 & 0.126 & $\mathrm{t}(36)=0.76$ & 0.4 \\
\hline $\begin{array}{l}\text { Watersheds with taconite activity } \\
\mathrm{n}=6\end{array}$ & 0.814 & 0.421 & & \\
\hline \hline $\begin{array}{l}\text { Watershed without low-grade ore } \\
\text { activity n=21 }\end{array}$ & 0.633 & 0.169 & $\mathrm{t}(36)=1.64$ & 0.11 \\
\hline $\begin{array}{l}\text { Watersheds with low grade ore } \\
\text { activity n=17 }\end{array}$ & 0.818 & 0.16 & & \\
\hline
\end{tabular}

\section{Discussion:}

This study asks: Do environmental impacts from historic iron mining in the Mesabi Range persist? Mapping historic mining and current lake water quality within the Mesabi Iron Range suggests that they do. HUC-12 subwatersheds that experienced historical mining activity are also the subwatersheds with a greater percentage of 
impaired lake acreage. These results suggest that historical iron ore mining may have influenced water quality in the Mesabi Range on a landscape scale, and that those legacies may persist after the mines and processing plants have closed.

Because the locations of high-grade and low-grade ore mining overlapped across the Mesabi Range, the possible effects of different types of mining activity produced within some watersheds could not be distinguished. However, relationships between historic mining activity and current water quality persisted even when watersheds that contained recent mining activity were removed from the analysis. This suggests that apparent water quality effects of historic mining activity are unlikely to be an artifact of current mining activity in the same subwatersheds.

Watersheds with recent taconite mining or processing did not contain a statistically significant higher proportion of impaired waters compared to watersheds without taconite activity. However, this does not necessarily mean that taconite mining and processing have protected water quality, because the MPCA has yet to assess many of the lakes in the subwatersheds where the most intensive taconite mining and processing occurred. Additionally, 95\% of the mine-pit lakes within the Mesabi Range have not been assessed for water quality by the MPCA. The data limitation in these lake assessments suggests a policy recommendation for the MPCA to include more mine pit lakes in water quality assessments and to assess waters within the HUC-12 subwatersheds that experienced taconite activity. Without those data, it is difficult to demonstrate the results of the taconite industry's efforts to protect water quality on a landscape-level scale.

The recreation of the historic waste footprints from aerial imagery and LiDAR data does have some limitations. Only the waste that is visible on the landscape today was able to be identified. The 
tailings that were deposited into surface waters, reclamation efforts such as re-vegetation, and successive waves of mining have made identifying some surface wastes challenging. Further research using advanced geospatial technologies such as photogrammetry may help identify the locations and quantity of additional historic waste footprints.

Within the Mesabi Range, some HUC-12 subwatersheds without mining had significant proportions of impaired lakes, showing that mining is not the only factor influencing water quality in the region. Nevertheless, within northeastern Minnesota where lake and stream water quality is generally better than in other, more developed parts of the state, the Mesabi Range stands out for its problematic water quality. ${ }^{63}$

In the United States alone, 40 percent of headwater streams in the western half of the nation are polluted by mining, and more than 19,000 kilometers of rivers are contaminated (Wernstedt and Hersh 2010). Efforts to regulate mine tailings and abandoned mines in the United States have a long and contested history. Across the United States, communities expressed concern about possible water quality impacts of mining as early as the late $19^{\text {th }}$ century, but had few legal tools available to limit pollution (Isenberg 2005; Hanak et al. 2011). The 1872 Mining Law, the first law to govern American mining, did not regulate water usage or tailings disposal, nor did it require reclamation of closed mines. The law's intent was to encourage mining by aiding the transfer of mining rights to private interests, not to regulate pollution (Wernstedt and Hersh 2010).

Federal mining policies that protected water quality were not enacted for another century. In 1972, the U.S. Congress passed amendments to the Federal Water Pollution Control Act (commonly known as the Clean Water Act) which established a regulatory 
structure for pollutants discharged into American waterways and established water quality standards for surface waters (Langston 2017). In 1974, the U.S. Forest Service began requiring reclamation on Forest Service lands after mines closed, and the Bureau of Land Management followed suit in 1981. The courts found that on public lands, federal and state regulations such as the Clean Water Act applied to mining, but these same regulations did not apply to mines that had been abandoned before the regulations were enacted. The passage of the 1977 Surface Mining Control and Reclamation Act established a program to reclaim mines after closure. However, according to a 1988 General Accountability Office report, approximately 114,000 hectares of abandoned or suspended operations have not yet been reclaimed (Surface Mining: Complete Reconciliation of the Abandoned Mine Land Fund Needed 1988).

Within the Lake Superior basin, the most notorious case involving water pollution from iron tailings was the Reserve Mining Company case. In 1947, the State of Minnesota gave permits to Reserve Mining Company allowing the company to dump 400 million tonnes of mining waste directly into Lake Superior. The waste contained asbestiform fibers, which made their way into the drinking water of Duluth, the largest city in the basin. By 1972, Duluth's drinking water contained over a billion fibers of asbestos per liter. Yet the state was unable to restrict the company's dumping of tailings into Lake Superior, and not until the federal government stepped in and took the company to court did the practice end, leaving a legacy of continuing water contamination (Langston 2017). 


\section{Conclusion:}

This study aims to understand if the locations and intensity of historic mining activity can help us understand the location of current impaired waters in watersheds. We began by creating an historic GIS from archival data, allowing us to visualize the historic mining landscape within a current watershed. We have previously quantified the visible extent of mine waste in the Mesabi Range, calculating that it covered 25\% more hectares than the original iron formation itself (Baeten et al.). Today, there are more than 250 lakes in the Mesabi Range that did not exist in 1890, and of the 4,945 hectares of lakes located within the Mesabi Range, $87 \%$ consist of abandoned mines which have filled with water. Yet few of these mine-pit lakes have been assessed by the MPCA for water quality. Additionally, the environmental impacts from mining can migrate far from the mining footprint, mobilizing into watersheds beyond the direct reaches of the mines.

Since the 1970s, regulatory efforts across the globe to improve water quality in mining regions have led to substantial improvements in current mining operations, but problems from historic and current iron mining persist (Muskie 1972). In the Rio Tinto region of Spain, more than 5,000 years of mining for iron as well as copper and manganese have produced legacy pollutants (Braungardt et al. 2003; Hudson-Edwards 2016). Tailings disasters have been common at abandoned and operating mines. On November 5, 2015, a tailings dam located near the town of Bento Rodrigues in southeast Brazil ruptured, sending roughly 60 million cubic meters of iron ore tailings into the Doce River Valley, killing 19 people. The tailings traveled more than 450 kilometers until reaching the Atlantic Ocean. Although Samarco, the mining company in charge of the dam, claimed that these iron ore tailings were an inert mixture of water, silica, and clay, a United 
Nations analysis showed that these tailings did contain a toxic mixture of heavy metals and chemicals.(Mud from Brazil dam disaster is toxic 2015) A year earlier, a tailings pond was breached at the Mount Polley copper and gold operation in Canada, contaminating waters downstream. In 2000, the Somes River in Romania was contaminated after the Baia Mare spill, where gold tailings were being treated with cyanide to extract additional value. In 1996, the Marcopper disaster in the Philippines inundated the Boac River with copper tailings. These disasters serve as examples of the continuing problems that can arise from tailings that mobilize into water systems (Plumlee et al. 2000).

Examining the effects of historic mines on current water quality helps communities develop effective regulations to prevent new mines from contaminating water. Mapping tailings locations and monitoring their water quality impacts require novel techniques that incorporate measures of historic mine waste as well as current mining operations. This paper shows that historic datasets can be used to inform current environmental decision-making. The so-called "soft data" found in the human processes that have historically transformed landscapes are often not fully explored or appreciated. Historical datasets, especially once spatialized, can help identify impacts from historic iron mining and provide environmental scientists and regulators with a better informed understanding of the challenges involved in landscape-scale remediation. This paper suggests a spatial and historical approach that land managers and policy makers can apply to assess the impacts of mining on affected watershed health. 


\section{Acknowledgements:}

This work was supported by the National Science Foundation (Grant \#R56645, Toxic Mobilizations in Iron Mining Contamination). The authors thank Kelley Christensen at Michigan Tech for helpful feedback and support. We thank the anonymous reviewers who provided invaluable feedback on an earlier draft of this manuscript. We also thank the MPCA for providing watershed datasets to the public. 


\section{References:}

2016 Minnesota Water Quality Surface Water Section (Abbreviated Narrative Report). 2017. General Report to the Congress of the United States Pursuant to Section 305(b) of the 1972 Clean Water Act. St. Paul, MN: Minnesota Pollution Control Agency. Anderson, P. 2016. Guidance Manuel for Assessing the Quality of Minnesota Surface Waters for Determination of Impairment: 305(b) Report and 303(d) List. 2016 Assessment and Listing Cycle.

Anderson, P., and I. Martin. 2015. Standard Operating Procedures (SOP): Lake Water Quality Sampling. St. Paul, MN: Minnesota Pollution Control Agency.

Anderson, P., W. Bouchard, D. Chrisopherson, M. Feist, and J. Genet. 2014. Guidance Manual for Assessing the Quality of Minnesota's Surface Waters for Determination of Impairment: 305(b) Report and 303(d) List. wq-iw-04. St. Paul, MN: Minnesota Pollution Control Agency.

Angelstam, P., K. Andersson, M. Isacson, D. V. Gavrilov, R. Axelsson, M. Bäckström, E. Degerman, M. Elbakidze, et al. 2013. Learning About the History of Landscape Use for the Future: Consequences for Ecological and Social Systems in Swedish Bergslagen. AMBIO 42: 146-159. doi:10.1007/s13280-012-0369-z.

Axler, R., C. Larsen, C. Tikkanen, M. McDonald, S. Yokom, and P. Aas. 1996. Water quality issues associated with aquaculture: a case study in mine pit lakes. Water Environment Research 68: 9951011.

Axler, Richard, S. Yokom, C. Tikkanen, M. McDonald, H. Runke, D. Wilcox, and B. Cady. 1998. Restoration of a Mine Pit Lake from Aquacultural Nutrient Enrichment. Restoration Ecology 6: 1-19. 
Baeten, J., N. Langston, and D. Lafreniere. A geospatial approach to uncovering the hidden waste footprint of Lake Superior's Mesabi Iron Range. The Extractive Industries and Society. doi:10.1016/j.exis.2016.09.003.

Bernhardt, E. S., B. D. Lutz, R. S. King, J. P. Fay, C. E. Carter, A. M. Helton, D. Campagna, and J. Amos. 2012. How Many Mountains Can We Mine? Assessing the Regional Degradation of Central Appalachian Rivers by Surface Coal Mining. Environmental Science \& Technology 46: 8115-8122. doi:10.1021/es301144q.

Bird, G. 2016. The influence of the scale of mining activity and mine site remediation on the contamination legacy of historical metal mining activity. Environmental Science and Pollution Research 23: 23456-23466.

Braungardt, C. B., E. P. Achterberg, F. Elbaz-Poulichet, and N. H. Morley. 2003. Metal geochemistry in a mine-polluted estuarine system in Spain. Applied Geochemistry 18: 1757-1771. doi:10.1016/S08832927(03)00079-9.

Byrne, P., P. J. Wood, and I. Reid. 2012. The Impairment of River Systems by Metal Mine Contamination: A Review Including Remediation Options. Critical Reviews in Environmental Science and Technology 42: 2017-2077.

Cherry, D. S., R. J. Currie, D. J. Soucek, H. A. Latimer, and G. C. Trent. 2001. An integrative assessment of a watershed impacted by abandoned mined land discharges. Environmental Pollution 111: 377-388.

Church, S. E., P. von Guerrard, and S. E. Finger. 2007. Integrated Investigations of Environmental Effects of Historical Mining in the Animas River Watershed, San Juan County, Colorado. U.S. Geological Survey Professional Paper 1651. 
Clifford, J. 2017. West Ham and the River Lea: A Social and Environmental History of London's Industrialized Marshland, 1839-1914. Vancouver, BC: UBC Press.

Cummins, A., and I. Given. 1973. SME Mining Engineering Handbook.

Vol. 2. New York: Society of Mining Engineers.

Cunfer, G. 2008. Scaling the Dust Bowl. In Placing History: How Maps, Spatial Data, and GIS are Changing Historical Scholarship, ed. Anne Kelly Knowles, 95-122. Redlands, CA: ESRI Press.

Davis, E. W. 1964. Pioneering With Taconite. St. Paul, MN: Minnesota Historical Society.

Forbes, J. 1953. Iron Ore. Minerals Yearbook Metals and Minerals. Bureau of Mines.

Grosbois, C., M. Meybeck, L. Lestel, I. Lefevre, and F. Moatar. 2012. Severe and contrasted polymetallic contamination patterns (1900-2009) in the Loire River sediments (France). Science of the Total Environment 435: 290-305.

Gutmann, M., D. Brown, A. Cunningham, J. Dykes, S. Hautaniemi Leonard, J. Little, J. Mikecz, P. Rhode, et al. 2016. Migration in the 1930s: Beyond the Dust Bowl. Social Science History 40: 707-740.

Hanak, E., J. Lund, A. Dinar, B. Gray, R. Howitt, J. Mount, P. Moyle, and B. Thompson. 2011. Managing California's Water: From Conflict to Reconciliation. Public Policy Institute of California.

Haunch, S. 2013. Legacy of historic mining and water quality in a heavily mined Scottish river catchment. PhD Thesis, Edinburgh: University of Edinburgh.

Haunch, S., and A. MacDonald. 2011. The Environmental Legacy of Historic Mining Activities in the Almond River Catchment, Scotland. In Mine Water - Managing the Challenges. Aachen, Germany.

Hubbard, J. 1948. Spiral Concentration. Mining World 13: 41-44. 
Hudson-Edwards, K. 2016. Tackling mine wastes. Science 352: 288290.

Hudson-Edwards, K., M. Macklin, and M. Taylor. 1997. Historic metal mining inputs to Tess river sediment. The Science of the Total Environment 194/195: 437-445.

Hunerlach, M. P., J. J. Rytuba, and C. N. Alpers. 1999. Mercury contamination from hydraulic placer-gold mining in the Dutch Flat mining district, California.

Hunt, M. 1951. Taconite: Iron Ore Bonanza. Steelways.

Impaired Lakes 2012. 2012. Minnesota Geospatial Commons (version Shapefile). Minnesota Pollution Control Agency.

Iron Ore Concentrating Plants of Minnesota. 1920. Skillings' Mining Review, September 4.

Isenberg, A. 2005. Mining California: An Ecological History. Hill and Wang.

James, L. A., and W. A. Marcus. 2006. The human role in changing fluvial systems: Retrospect, inventory and prospect. Geomorphology 79: 152-171.

Johnson, D. B., and K. Hallberg. 2005. Acid mine drainage remediation options: a review. Science of the Total Environment 338: 3-14.

Keeling, A., and J. Sandlos. 2015. Mining and communities in Northern Canada: history, politics, and memory. University of Calgary Press.

Kohn, C., and R. Specht. 1958. The Mining of Taconite, Lake Superior Iron Mining District. Geographical Review 48: 528-539.

Lakes and water quality. 2017. Government. Minnesota Pollution Control Agency.

Langston, N. 2017. Sustaining Lake Superior. New Haven, CT: Yale University Press. 
LeCain, T. 2009. Mass Destruction: The Men and Giant Mines that Wired America and Scared the Planet. New Brunswick: Rutgers University Press.

LeClerc, E., and Y. Wiersma. 2017. Assessing post-industrial land cover change at the Pine Point Mine, NWT, Canada using multitemporal Landsat analysis and landscape metrics. Environmental Monitoring \& Assessment 189: 19.

LiDAR Elevation, Arrowhead Region, NE Minnesota, 2011. 2011. Shape and File GeoDataBase. St. Paul, MN: Minnesota Department of Natural Resources. Davis, Kellogg \& Severance Law Firm Records.

LiDAR Elevation, Central Lakes Region, Minnesota, 2012. 2012. Shape and File GeoDataBase. St. Paul, MN: Minnesota Department of Natural Resources.

Limerick, P. N., J. Ryan, T. Brown, and T. A. Comp. 2005. Cleaning up Abandoned Hardrock Mines in the West: Prospecting for a Better Future. 7. University of Colorado at Boulder: Center for the American West.

MacFarlane, D. 2016. Waukesha and Great Lakes Water: Some Historical Background. NiCHE: Network in Canadian History \& Environment.

MacKenzie, A. B., and I. D. Pulford. 2002. Investigation of contaminant metal dispersal from a disused mine site at Tyndrum, Scotland, using concentration gradients and stable $\mathrm{Pb}$ isotope ratios. Applied Geochemistry 17: 1093-1103.

Macklin, M. G., K. A. Hudson-Edwards, and E. J. Dawson. 1997. The significance of pollution from historic metal mining in the Pennine orefields on river sediment contaminant fluxes to the North Sea. Science of the Total Environment 194/195: 391-397. 
Manuel, J. T. 2015. Taconite Dreams: The Struggle to Sustain Mining on Minnesota's Iron Range, 1915-2000. Minneapolis, MN: University of Minnesota Press.

McGarvey, D. J., and J. M. Johnston. 2013. “Fishing” for Alternatives to Mountaintop Mining in Southern West Virginia. AMBIO 42: 298308. doi:10.1007/s13280-012-0346-6.

Miller, J. 1997. The role of fluvial geomorphic processes in the dispersal of heavy metals from mine sites. Journal of Geochemical exploration 58: 101-118.

Mineland Reclamation: Minnesota's Program. 1988. Minnesota Department of Natural Resources: Division of Lands and Minerals.

Mineral Resources Data System. 2005. Shape and File GeoDataBase. Reston, Virginia: U.S. Geological Survey.

Minnesota Pollution Control Agency. 2008. Appendix A: Impaired Waters and TMDL Fact Sheets and Maps. St. Paul, MN: Minnesota Pollution Control Agency.

Minnesota’s Impaired Waters List. 2017. Government. Minnesota Pollution Control Agency.

Moore, J. N., and H. W. Langer. 2012. Can a river heal itself? Natural attenuation of metal contamination in river sediment. Environmental Science \& Technology 46: 2616-23.

Moore, J. N., and S. N. Luoma. 1990. Hazardous wastes from largescale metal extraction. Environmental Science \& Technology 24: 1278-1285.

Mud from Brazil dam disaster is toxic, UN says, despite mine operator denials. 2015. The Guardian, November 25.

Muskie, E. 1972. Clean Water Act. 40 C.F.R.

Pellicori, D. A., C. H. Gammons, and S. R. Poulson. 2005. Geochemistry and stable isotope composition of the Berkeley pit lake and 
surrounding mine waters, Butte, Montana. Applied Geochemistry 20: 2116-2137. doi:10.1016/j.apgeochem.2005.07.010.

Plumlee, G. S., R. A. Morton, T. P. Boyle, J. H. Medlin, and J. A. Centeno. 2000. An Overview of Mining-Related Environmental and Human Health Issues, Marinduque Island, Philippines: Observations from a Joint US Geological Survey-Armed Forces Institute of Pathology Reconnaissance Field Evaluation, May 12-19, 2000. US Geological Survey Open-File Report.

Quivik, F. 1998. Smoke and tailings: An environmental history of copper smelting technologies in Montana, 1880-1930.

Dissertation, University of Pennsylvania.

Ross, M. R., B. L. McGlynn, and E. S. Bernhardt. 2016. Deep Impact: Effects of Mountaintop Mining on Surface Topography, Bedrock Structure, and Downstream Waters. Environmental Science \& Technology 50: 2064-2074.

Savage, K., D. Bird, and R. Ashley. 2010. Legacy of the California Gold Rush: Environmental Geochemistry of Arsenic in the Southern Mother Lode Gold District. International Geology Review 42: 385415.

Seaber, Paul, Kapinos, Paul, and G. Knapp. 1994. Hydrologic Unit Maps. United States Geological Survey Water-Supply Paper 2294. U.S. Department of the Interior.

Singer, M. B., R. Aalto, L. A. James, N. Kilham, J. Higson, and S. Ghoshal. 2013. Enduring legacy of a toxic fan via episodic redistribution of California gold mining debris. Proceedings of the National Academy of Sciences 110: 18436-18441. doi:10.1073/pnas.1206191109.

Sullivan, M. 2014. Tainted Earth: Smelters, Public Health, and the Environment. New Brunswick: Rutgers University Press. 
Surface Mining: Complete Reconciliation of the Abandoned Mine Land

Fund Needed. 1988. GAO/RCED-89-35. Government

Accountability Office.

Taggart, A. 1927. Handbook of Ore Dressing. New York: John Wiley \& Sons, Inc.

Technical Resource Document: Extraction and Beneficiation of Ores and

Minerals. 1994. EPA 530-R-94-030. Washington, DC: U.S.

Environmental Protection Agency: Office of Surface Waste.

The 8, 10, and 12 hydrologic unit boundaries for Minnesota. 2008.

Vector digital data. Mounds View, Minnesota: USGS.

The Lake Superior District. 1920. The Iron Trade Review 66.

Thomas, M. A., C. H. Conaway, D. J. Steding, M. Marvin-DiPasquale, K.

E. Abu-Saba, and A. R. Flegal. 2002. Mercury contamination from historic mining in water and sediment, Guadalupe River and San

Francisco Bay, California. Geochemistry: Exploration,

Environment, Analysis 2: 211-217.

Van Allen, N., and D. Lafreniere. 2016. Rebuilding the Landscape of the

Rural Post Office: A Geo Spatial Analysis of the 19th Century

Postal Space and Networks. Rural Landscapes: Society,

Environment, History 3: 1-19.

Van Barneveld, C. E. 1913. Iron Mining in Minnesota. Minnesota School

of Mines Experiment Station Bulletin 1. Minneapolis, MN:

University of Minnesota.

Walker, S. R., H. E. Jamieson, A. Lanzirotti, G. E. M. Hall, and R. C.

Peterson. 2015. The effect of ore roasting on arsenic oxidation

state and solid phase speciation in gold mine tailings.

Geochemistry: Exploration, Environment, Analysis 15: 273-291.

Water Quality: Describing Water Quality. 2017. Government. Minnesota

Department of Natural Resources. 
http://www.dnr.state.mn.us/whaf/about/5-

component/wq_concepts.html. Accessed July 25.

Water Quality Standards. 2017. Government. Minnesota Pollution

Control Agency. https://www.pca.state.mn.us/water/waterquality-standards. Accessed February 28.

Watershed Boundary Dataset (WBD). ESRI Shape and File GeoDataBase. USGS and USDA - NRCS.

Wernstedt, K., and R. Hersh. 2010. Abandoned Hardrock Mines in the United States: Escape from a Regulatory Impasse. Wm. \& Mary Pol'y Rev. 1: 25.

Worrall, R., D. Neil, D. Brereton, and D. Mulligan. 2009. Towards a sustainability criteria and indicators framework for legacy mine land. Journal of Cleaner Production 17: 1426-1434.

Yellishetty, M., P. G. Ranjith, and A. Tharumarajah. 2010. Iron ore and steel production trends and material flows in the world: Is this really sustainable? Resources, Conservation and Recycling 54: 1084-1094. doi:10.1016/j.resconrec.2010.03.003.

Young, G. 1932. Elements of Mining. New York: McGraw-Hill Book Company, Inc.

Younger, P., and C. Wolkersdorfer. 2004. Mining Impacts on Fresh Water Environment: Technical and Managerial Guidelines for Catchment Scale Management. ERMITE Report: D6, The European Commission Fifth Framework Programme, Energy Environment and Sustainable Development.

Zellie, C. 2005. Mesabi Iron Range Historic Contexts, Itasca and St. Louis Counties, Minnesota Phase III Mitigation Study TH 169. St. Paul, MN: Federal Highway Administration and Minnesota Department of Transportation. 


\title{
Chapter 4: Contested Landscapes of Displacement: Oliver Iron and Minnesota's Hibbing District ${ }^{1}$
}

\begin{abstract}
:
This paper explores the ways that communities, the iron industry, and the state responded to iron mining development in Minnesota's Mesabi Range. The Mesabi Range in northern Minnesota was the most productive iron range in the United States from 1895 to today, producing more than 3.8 billion tons of iron ore. The removal of all of this iron produced tremendous landscape changes, which communities in the Mesabi Range had to negotiate.
\end{abstract}

As open pit mines expanded during the 1910s, all but two communities were forced to relocate to make way for an expanding mine. Archival records reveal that communities contested mining displacements, yet this social negotiation over mining is relatively absent in current interpretative discourse. Instead, state agencies have reimagined the mining landscape, filling former mines with trout, and removing much of the built environment in an effort to promote a recreational landscape atop a post-industrial. These actions have fostered a distorted collective memory of the region's past and an industrial landscape where historical features are treated as recreational areas rather than cultural resources.

${ }^{1}$ This chapter was submitted to Change Over Time: An International Journal of Conservation and the Built Environment, for a forthcoming issue on Landscapes of Extraction, as: John Baeten, Contested Landscapes of Displacement: Oliver Iron and Minnesota's Hibbing District. 


\section{INTRODUCTION:}

The expansion of mining in Minnesota's Mesabi Range produced changes at a landscape scale, evident in the mass displacement of communities, the creation of hundreds of new water bodies, and the replacement of hills with piles of mine waste. This paper asks: how did communities in the Mesabi Range respond to mining developments? How did the state of Minnesota respond to community and company concerns? How are the landscape alterations and the community negotiations around mining memorialized in the heritage discourse that developed within the Range?

This paper explores two case studies in which one company, the Oliver Iron Mining Co., used legal precedents and political power to transform the cultural and natural landscape of the Hibbing Mining District in the Mesabi Range. During the early 1900s, the largest corporation in the world, U. S. Steel, formed a mining branch called the Oliver Iron Mining Co. (henceforth Oliver Iron). Oliver Iron became heavily invested in the Mesabi Range, and in 1912, three of its open-pit mines at Hibbing began to encroach on the town itself, resulting in the relocation of the largest town on the range. Using archival materials, we examine the claims made by the company, and local citizens as they contested new mining development. As citizens protested the relocation of Hibbing, Oliver Iron also began developing the Carson Lake project, which would transform a recreational lake into a mine. Both initiatives directly impacted the residents of the Hibbing District. As iron mining began to decline in the 1970s, a Minnesota state agency named The Iron Range Resources and Rehabilitation Board developed programs to help the region's economy by promoting outdoor recreational tourism such as scuba diving, fishing, and mountain biking within the industrial landscape. This paper examines 
how this agency memorialized mining's past in an effort to meld the Mesabi's industrial past with a future based on recreation.

\section{MINING EXPANSION ACROSS THE RANGE}

For the past 120 years, the Lake Superior Iron District has been the top producer of iron ore in the United States. After the Civil War, a growing North American industrial economy required steel, and the iron ranges of Minnesota, Wisconsin, and Michigan, collectively known as the Lake Superior Iron District, contained the continent's most important source of iron. ${ }^{1}$ By 1890, the Lake Superior district produced more than $50 \%$ of the iron ore used by the American iron and steel industry, and by the end of World War II, the district produced $85 \%$ of the nation's iron ore. ${ }^{2}$ After World War II, the Mesabi Range of Minnesota became the dominant iron producer in the Lake Superior Iron District, and by 1980, mines in the Mesabi accounted for $80 \%$ of the iron produced in the Lake Superior District.

Iron mining in the Mesabi Range underwent three technological phases: The mining of high-grade direct shipping ore (1893-1970s); the mining of lower grade washable ores (1910-1980s); and the mining of taconite (1940s-today), the lowest grade of iron in the Lake Superior basin. ${ }^{3}$ These phases of mining are connected by the open-pit mining system employed by mining companies in the region.

The first iron mines on the Mesabi Range opened in the 1890s and consisted of a mixture of underground and open-pit mines. Unlike the vertically arranged ore bodies found elsewhere in the Lake Superior Iron District, the Mesabi Range's ore body (called the Biwabik formation) was generally horizontal (Figure 4.1$).{ }^{4}$ The stratigraphy of the Mesabi's ore body allowed mining companies to employ less expensive and larger-scale open-pit mining technologies. Open-pit mining technologies, such as the large steam shovels used in the 
Mesabi Range during the late $19^{\text {th }}$ century, have been credited as principal factors in the modernizing of American mining methods, and bolstered the Lake Superior district's role as the leading iron producer in the United States. ${ }^{5}$ Open-pit mining technologies were engineered to extract vast quantities of material indiscriminately, and spurred a rapid development of large-scale mining in the Mesabi Range. ${ }^{6}$

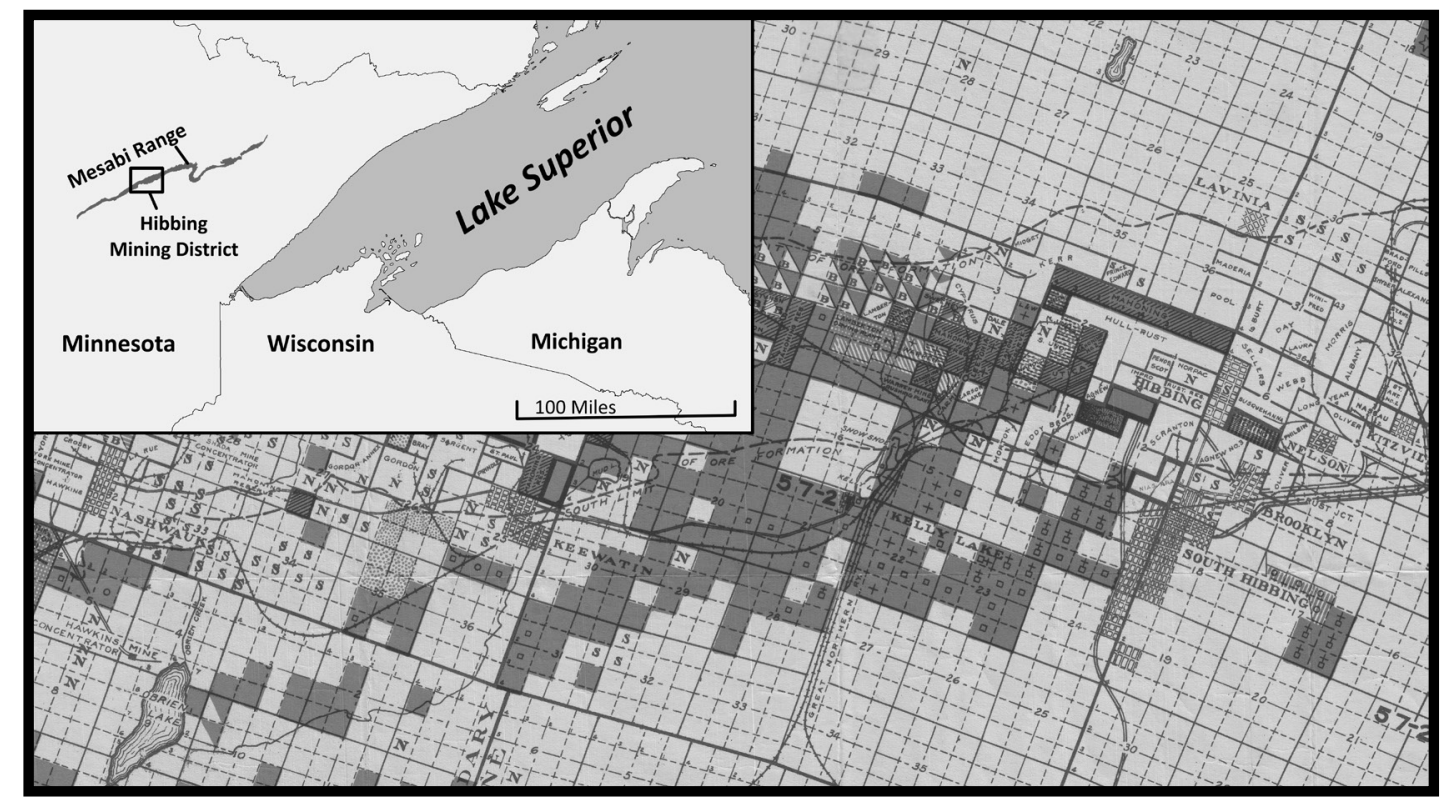

Figure 4.1: Overview of the Mesabi Range and the Hibbing Mining District (Map of the Mesabi Range-Great Northern Iron Ore Properties, 1923, John R. Borchert Map Library at the University of Minnesota)

In addition to open-pit mining technologies, national economic transformations also helped Mesabi Range mining companies develop into the world's largest iron ore producers. Between 1896 and 1900, vertically integrated large steel corporations, such as U.S. Steel, who controlled the steel mills and also the iron mines that supplied them, replaced smaller steel companies. ${ }^{7}$ Corporate funds coupled with federal involvement enabled these transformations, such as the construction of Sault Ste. Marie locks in 1855, which helped spur the 
development and expansion of the Lake Superior Iron District. ${ }^{8}$ In the 20th century, government investments in infrastructure and new tax policies made possible the boom in taconite. ${ }^{9}$

The success of these vertically integrated iron and steel corporations transformed the physical, social, and economic landscape of the Mesabi Range. As open-pit mines expanded, communities on the Mesabi Range were literally undermined. Strikingly, all but two towns on the range were displaced in some way by open-pit mining. ${ }^{10}$ This phenomenon of mining-induced displacement and resettlement has affected communities across the globe. ${ }^{11}$ Often, mining-induced displacement and resettlement leads to poverty when property owners are inadequately compensated for their homes, a concern that property owners in the Mesabi Range voiced as growing open-pit mines encroached on their communities. Because the iron industry was the largest employer in the Mesabi Range, industry officials argued that the success of the mines correlated with the success of Mesabi Range communities. The iron mining industry possessed significant political power in the Range, yet archival records show that community members often resisted these displacements.

Mining landscapes such as the Mesabi Range can be read as a narrative where abstract human agency and material technologies interact with natural systems. Mining landscapes are often hybrid in nature, created from the introduction of new technologies, which rework and destroy the historical landscape produced from earlier mining technologies. Hybrid mining landscapes occur when successive waves of new technologies ultimately replace the footprint of existing and obsolete technologies. ${ }^{12}$ The historical footprint of mining on the Mesabi Range was subjected to a series of technological changes, resulting in a landscape that shows abandonment, re-work, and reclamation. 
While the technologies used in open-pit mining have reworked many of the landscape features characteristic of more historical mining, remediation and heritage efforts focused on tourism have also obscured much of the Mesabi Range's mining legacy on the landscape. Heritage efforts on the Mesabi focused on trying to "recycle a mining landscape", by intersecting a "technological wonderland" with a vision of a recreational future. ${ }^{13}$ The Iron Range Resources \& Rehabilitation Board (IRRRB), a state agency funded by taconite tax revenue, has functioned as the principal force in the transformation of the Mesabi Range into a recreational landscape. The IRRRB acts as a primary driver of promoting the cultural and natural heritage of the Mesabi Range, in an effort to diversify and strengthen the region's economy. ${ }^{14}$ Although the conservation of the built environment was not a priority of the IRRRB, the Mesabi Range retains distinct features of its industrial past, in such things as standing head frames, open-pit mines, waste piles, and in situ machinery..$^{15}$ The iron industry, Mesabi Range communities, and Minnesota lawmakers all played important roles in shaping the iron range. This paper explores how responses to mining expansion and decline shaped the political, cultural, and natural landscape of the range, and the contested negotiations that they spurred.

\section{MINNESOTA TAX POLICY AND THE RICHEST VILLAGE IN THE WORLD}

Historically, the Mesabi Range contained six mining districts, of which the Hibbing district was the most productive. Mining in the Hibbing district grew from six mines in 1900 to nearly 60 in 1917, and production of iron increased from 1.2 million tons to 23.5 million tons. By 1917, four of the largest mines in the Hibbing district - the 
Hull, Rust, Sellers, and Susquehanna - were clustered near the Mesabi Range's largest city, Hibbing (Figure 4.2).

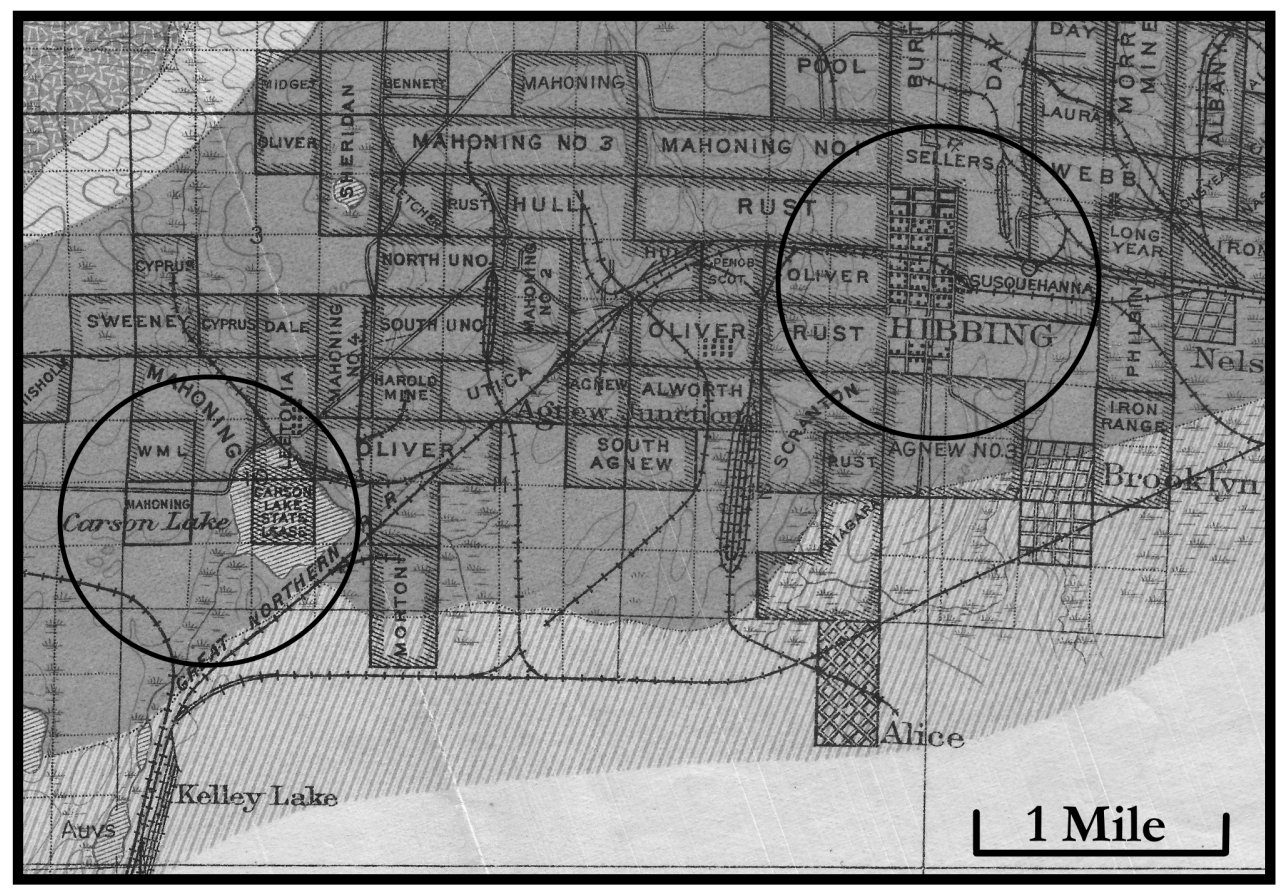

Figure 4.2: Overview of Hibbing and Carson Lake (Geologic Map of the Mesabi District, MN, USGS Monograph No. 43, John R. Borchert Map Library at the University of Minnesota)

The town of Hibbing was platted in 1893. In 1896, the original plat was expanded to the south, with the 40-acre Pillsbury addition, the first of many additions that would soon be annexed to the townsite. ${ }^{16}$ By the late 1890 s, mining companies had identified a vast ore body in the region, and began to take out new mining leases in the area. Although iron mines were developing rapidly around Hibbing, it was later argued that when the original Hibbing townsite was platted there was no knowledge of the ore located below the townsite, and if this knowledge existed, the townsite wouldn't have been platted in the first place. ${ }^{17}$ 
Roughly 1,800 individuals made Hibbing their home by 1900 . The success of the mines continued to draw more people to Hibbing, and by 1908 the population of the city had reached 10,000 and continued to grow. Since an expanding open-pit mine was located immediately north of the townsite, the only direction the community could physically expand was to the south.

The growth of the iron industry resulted in an influx of mineworkers to the region, leading to a population boom in Hibbing from 1,800 residents in 1900 , to 15,000 in 1915 . In turn, this population growth meant the community needed to fund significant infrastructure and public services. To meet these needs, Hibbing and other range communities relied upon municipal funding generated by taxes on the iron industry.

In 1899, Minnesota legislators passed an act allowing for the leasing of state-owned minerals to iron mining companies. This act allowed iron mining companies to apply for contracts to develop state-lands for mining, with a royalty rate of $\$ 0.25$ per ton of ore extracted. In 1907, state legislators who believed the royalty rate was too low repealed the provisions of the 1899 act. ${ }^{18}$ By the 1910 s, Minnesota was taxing the mining industry for both the ore removed and the ore still in the ground. Local officials in cities, such as Hibbing, attempted to recoup as much of this revenue as possible to use for civic improvements. Taxes on iron mining companies factored in the total value of the ore within the mining companies' leases, and the tax rate applied to mining companies in Minnesota was higher than the rate applied to any other industry in the state. ${ }^{19}$ State lawmakers justified these high tax rates by arguing that the ore removed was part of a "publicly-created value", and the profits that the mining companies enjoyed should also be shared with the public. ${ }^{20}$ Minnesota lawmakers hoped that these tax revenues would bring civic 
improvements to mining communities, fostering a climate in which Minnesota legislative historian J.C. Buell reported in 1915, "There will not be so many useless millionaires in the world; but there will be more useful citizens who can afford to have decent homes and comfortable surroundings." ${ }^{21}$

Tax revenues provided mining communities like Hibbing with paved roads, good schools, and sewer lines. By the mid-1910s, Hibbing was known as the "richest village in the world." ${ }^{22}$ The background to this moniker was twofold: First, the city was located atop a vast deposit of iron ore; secondly, the politicians of the city had used the iron mining tax dollars to develop civic amenities that rivaled some of the largest cities in the United States. Mining company officials began to argue that these services were excessive, and in 1913 mining company executives formed the Lake Superior Tax Association, an organization devoted to curtailing taxation in the Mesabi Range. ${ }^{23}$ In 1914, Oliver Iron officials claimed that Hibbing had more electric streetlights than Cincinnati, a city of $400,000 .{ }^{24}$ Electric streetlights, publicly funded baseball teams, a large police force, and paved streets became, in mining company discourse, examples of city officials mismanaging and abusing tax revenue (Figure 4.3). Rumors spread that "Hibbing schools had cut-glass doorknobs, and the flagpoles were covered with gold leaf," and mining company officials argued that city officials on the Mesabi Range had acted as "hold-up men, or specialists in town improvement," and charged them with lootingfrom the mining industry. ${ }^{25}$ 


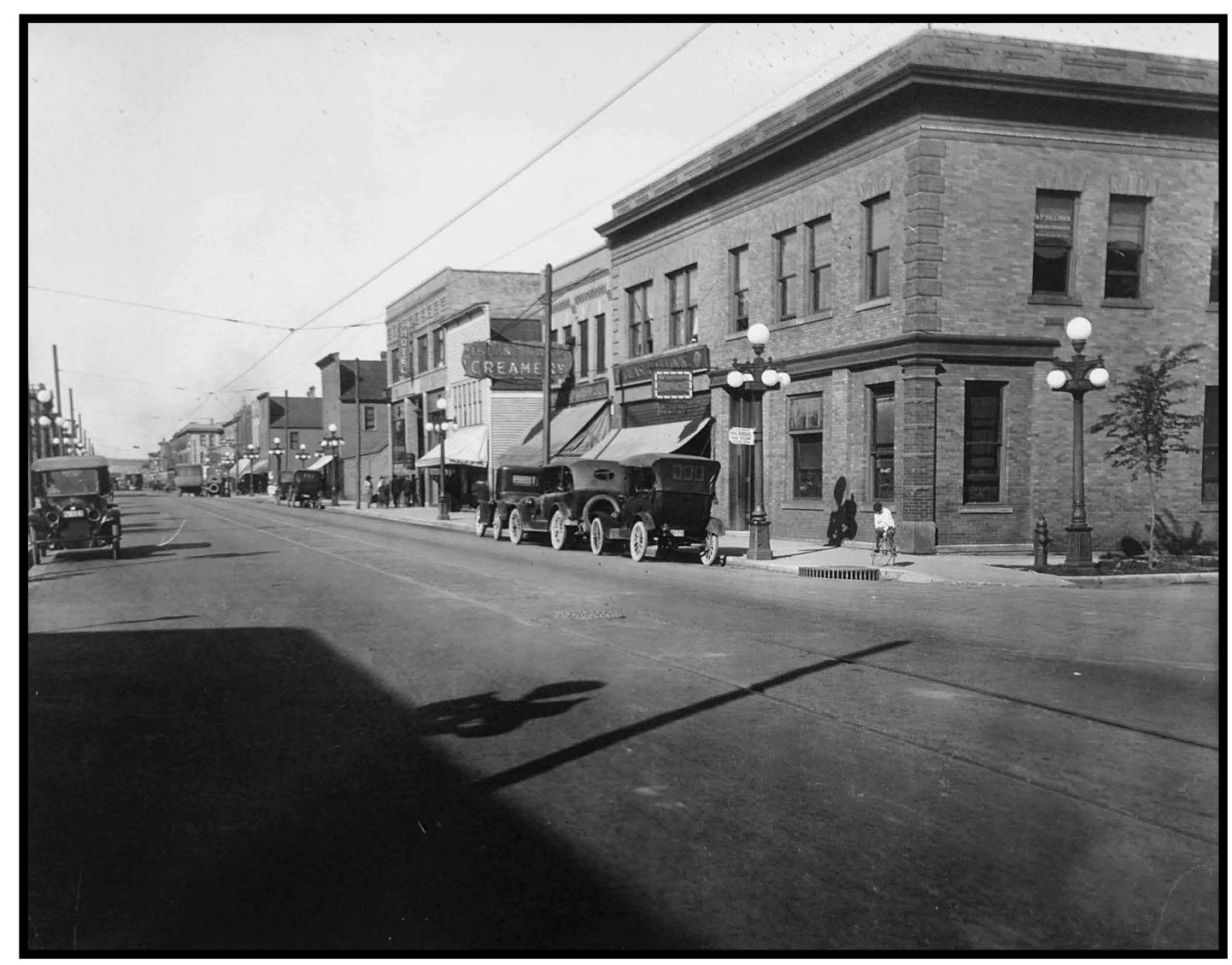

Figure 4.3: North Hibbing, circa 1920 (Davis, Kellogg \& Severance Records, Gale Family Library, Minnesota Historical Society)

Oliver Iron claimed that not only were city officials spending tax revenue extravagantly, but that the Minnesota tax system in general was exploitative to industry and needed revision. Working with John Harrison, a state congressman from Minneapolis, Oliver Iron helped draft "The Harrison Bill," which was introduced to the Minnesota state legislature in 1915. The Harrison Bill would have lowered taxes on mines in the iron ranges, by placing a maximum flat tax of \$25 per annum for municipal purposes for iron mining companies, compared to the roughly $\$ 750,000$ owed by Oliver Iron to Hibbing in 1914 alone (in contrast, the iron mines of Michigan paid between $\$ 8$ - $\$ 10$ a year). ${ }^{26}$ Local newspapers argued largely in favor of the communities, which 
championed the high tax rates placed on the mining companies, stating, "Every cent possible should be collected from the mining companies while they are with us, to the end that we may retain unto ourselves a share of the wealth that, once removed, will never return." ${ }^{27}$ Additionally, city officials pitted the bill as a fight between range communities and eastern capitalists, instilling regional pride in opposition to the bill.

The Harrison Bill was passed by the state senate, but was eventually rejected by the house. In response, Oliver Iron, along with other mining companies, protested the decision and refused to pay the owed municipal taxes to the mining communities. As a result, the city filed for an injunction against the mining companies until taxes were paid. Hibbing's mayor, Victor Power, next lobbied the state to adjoin the mining companies from shipping any ore in stock or at the port of Duluth, until the delinquent taxes were paid. By November 1916, the mining companies and the city resolved the dispute out of court, in a closed-door meeting with Mayor Power, with the mining companies agreeing to pay the owed back taxes. This meeting would later be used as evidence in the injunction case that charged city officials with colluding with Oliver Iron in the relocation of the townsite and the monopolization of the new commercial district.

\section{A CONTESTED LANDSCAPE OF DISPLACEMENT: HIBBING AND OLIVER IRON}

By the mid-1910s, open-pit mines in the Hibbing mining district were expanding rapidly, and the most intensive mining took place at the mines surrounding Hibbing. As open-pit mining transformed their landscape, many Hibbing community members began to fear one of two things: either the ore was nearing depletion and the mines would soon leave, or the mines themselves would continue to grow, 
eventually forcing the community to relocate. These fears grew in part from the excavation of a "canal" around 1910, which Oliver Iron dug to combine the open-pit excavations of the Rust mine with the Sellers and Susquehanna mines located just north of town. The digging of this canal removed a public road and the "direct means of ingress and egress to and from the village." ${ }^{28}$ In a later injunction suit against the mining company, plaintiffs argued that Oliver Iron, "simply cut the road, without any authority" and replaced it with a steel bridge "for the purpose of public travel." ${ }^{29}$ Although Oliver Iron paid for the bridge, the village of Hibbing took ownership for its upkeep and maintenance. This all took place almost a decade prior to the relocation of the city itself.

To curb fears of displacement, W.J. Olcott, president of Oliver Iron, published an editorial in the Hibbing Daily Tribune on February 12,1912 , assuring community members that the original townsite was safe from mining for "the next fifteen years", and that rumors of a planned relocation were unsubstantiated. ${ }^{30}$ At the same time, Oliver Iron began purchasing surface lots in the town of Hibbing, adding city blocks to their vast holdings of mineral rights. ${ }^{31}$

However, after the settlement of the tax dispute in 1916, residents of Hibbing learned that Oliver Iron and city officials had developed plans to promote the development of Alice with the goal of vacating the original townsite and eventually mining it. As this decision became public, Oliver Iron continued to purchase townsite lots, and razed the structures located on them. Working with city officials, Oliver Iron developed a plan to relocate the city two miles south to the Alice addition (Figure 4.4). By 1918, Oliver Iron owned 427 of the 474 lots in the original townsite, or more than $90 \%$ of the surface rights. ${ }^{32}$ City officials, local newspapers, and the iron industry championed the decision to relocate as a small inconvenience that 
came with the benefits of continual industrial prosperity. But a group of Hibbing community members felt otherwise. In October of 1919, Hibbing businessman H.P. Reed and roughly 150 other residents filed an injunction against Oliver Iron, the Village of Hibbing, and the Mesaba Railway Co. ${ }^{33}$ The plaintiffs in the lawsuit argued there was a conspiracy between the defendants to vacate the original townsite to allow for the expansion of open-pit mining and to increase the value of their property in the Alice addition.

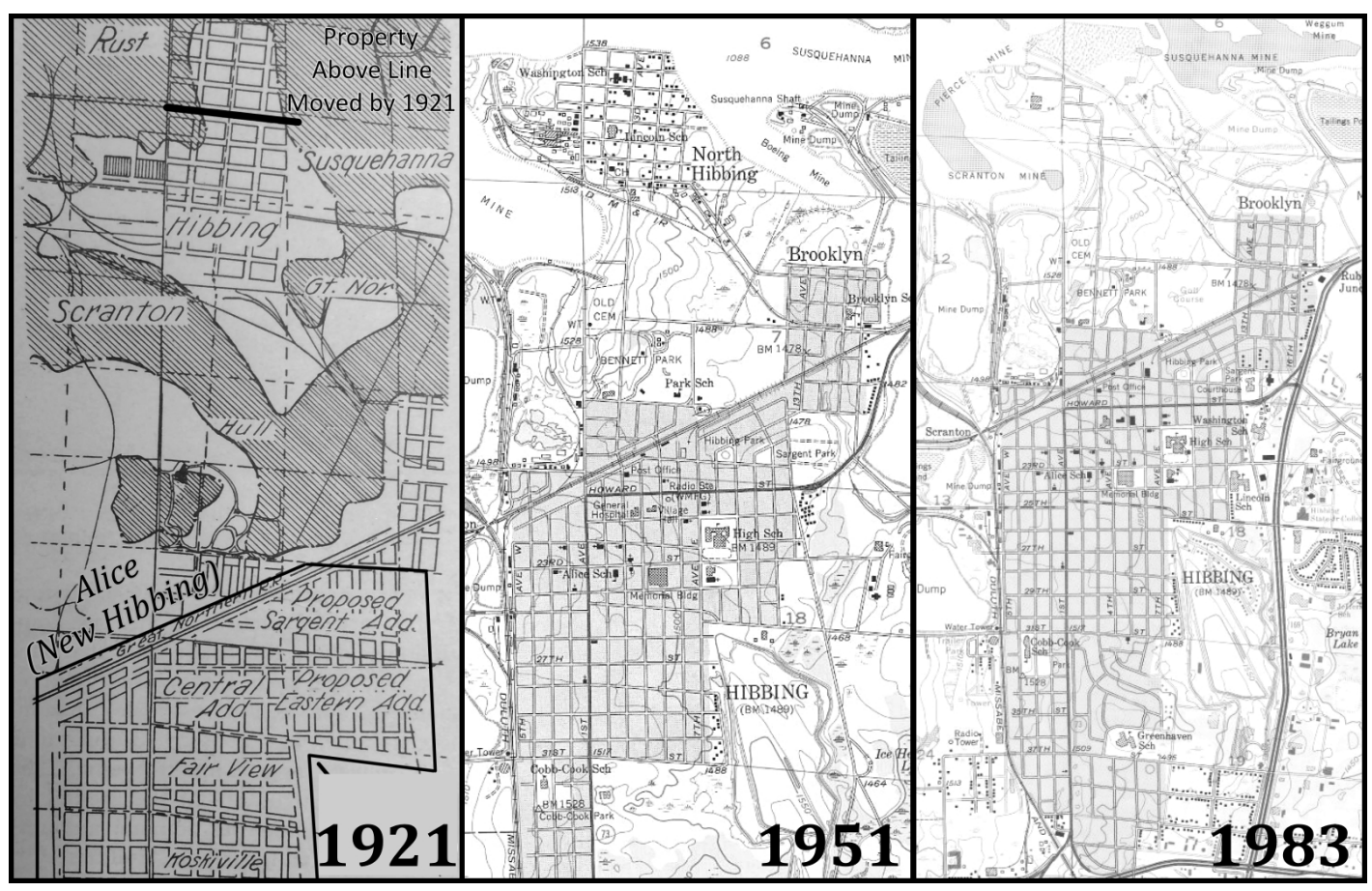

Figure 4.4: Mapped landscape change in Hibbing, 1921, 1951 and 1983 (Iron Trade Review, 1921; USGS Hibbing, MN Quadrangles 1951 and 1983)

By 1919, a new business district had been developed in the Alice addition and buildings from the old townsite began to be relocated. The plaintiffs felt that these Alice business owners were given an unfair advantage in the locating of their properties. Public funding of a new hospital coupled with extensive municipal improvements, 
accelerated development in the Alice addition. Next, the Mesaba Rail Co, which owned the passenger rail service, extended tracks from the original Hibbing townsite to Alice and Brooklyn. By the fall of 1919, the Mesaba Rail Co. applied to abandon the passenger rail service at the original townsite. ${ }^{34}$ Reed and the other plaintiffs saw their properties rapidly lose value. Not only had the mining company bought up the majority of the properties surrounding their businesses, but the transportation system which brought customers to their doors was about to be vacated. These business owners demanded that Oliver Iron provide financial compensation for their property, which they felt the defendants' actions had devalued. Judge Freeman granted the trial for the injunction case, setting the date for February $1920 .^{35}$

Represented by H.V. Mercer, the plaintiffs argued that the reorganization of the city of Hibbing to include the addition of Alice was conducted in private between city officials and Oliver Iron, and without a vote by the townspeople. ${ }^{36}$ The plaintiffs argued that the move to Alice would harm the community, and that the relocation was designed to give city officials, such as Mayor Power, and the mining and railway companies total ownership over the new commercial and retail districts. City officials countered that relocating the city to Alice offered a permanent location for Hibbing to continue to develop, and because it was located far from the ore body, the town need not fear future displacement. The defense relied on testimonies from prominent Hibbing residents, Oliver Iron management, and city officials. They denied the claims of collusion, and they argued that mining under the city was essential for the local economy and provided broader public benefits.

The plaintiffs argued that Oliver Iron's open-pit mines had inundated the Hibbing townsite with coal smoke, flying debris, and 
loud blasts. They further charged that Oliver was intentionally conducting operations as disruptively as possible in an effort to force the remaining residents of the townsite to leave ${ }^{37}$ Local residents testified that blasting operations shattered windows, and airborne mine waste crashed through doors. For example, W.J. Ryder, a business owner, testified that he "was setting glass that was blown out by blasts until two years ago practically every day." ${ }^{38}$ Such mining practices constituted environmental coercion that pressured many Hibbing residents to agree to Oliver's terms (Figure 4.5).

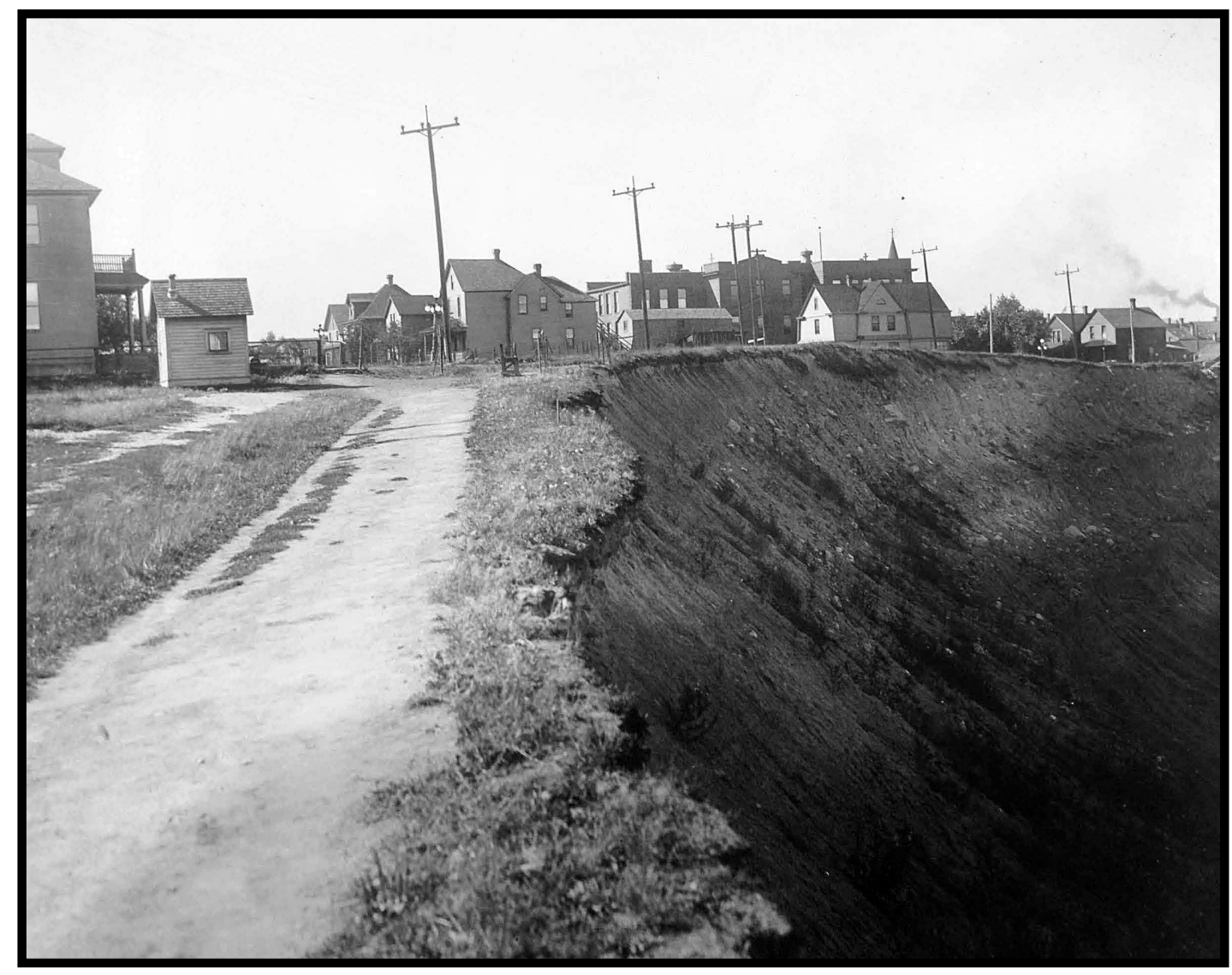

Figure 4.5: Open-pit mine encroaching on North Hibbing, circa 1920

(Davis, Kellogg \& Severance Records, Gale Family Library, Minnesota Historical Society) 
The defense countered with C.M. Atkinson, editor of the local Mesaba Ore newspaper testifying that that the movement of residents into the southern sections of Hibbing was voluntary. ${ }^{39}$ Rather than being coerced, Oliver argued residents understood mining's advance was inevitable, so relocating to the south would provide permanence. ${ }^{40}$ M.H. Godfrey, the Western District manager for Oliver Iron, argued that Hibbing residents knew they lived in a community "wholly dependent upon the mining industry, and therefore they knew that they must assume whatever inconveniences and discomforts might necessarily arise from such mining operations." ${ }^{41}$

W.J. Olcott, who had assured Hibbing residents in 1912 that the town would be safe from mine encroachment for 15 years, argued in his affidavit that the Hibbing townsite was a primitive location "put up of cheap construction," while the new locations offered both stability and modernity. ${ }^{42}$

In January of 1921, Judge Freeman denied the injunction request against Oliver Iron and the Village of Hibbing, finding that the plaintiffs in the suit had not suffered any damages from the city relocating. ${ }^{43}$ The plaintiffs appealed to the Minnesota Supreme Court, which sided with Judge Freeman's decision. This decision stated that: "No court would stop a great mining enterprise; that for the industry to exist it was necessary to endure the disturbances and discomforts that were unavoidable in their operations; that the use and development of the natural resources gave employment, provided revenue for the owner, the nation, the state and the municipality and should not be interfered with; and that it was the duty of the village and the taxpayer to permit the lands to be mined." ${ }^{44}$ The United States Supreme Court refused to hear the case, and so the displacement went forward. By 1922, Oliver Iron had purchased the majority of the original townsite of Hibbing, renamed it the "North Forty", and razed 
or relocated the majority of the remaining structures south to Alice, the location of modern-day Hibbing. In January of 1924, the roads running to and from the original Hibbing townsite were closed, and Oliver Iron's steam shovels began stripping the surface of the old town. ${ }^{45}$

The relocation and mining of Hibbing pitted local residents and business owners against the biggest employer in the Hibbing district. Roughly 15,000 people were displaced, while the civic improvements that fueled the tax dispute of 1915 were torn down to make way for the expanding pit.

\section{DRAINING A LAKE TO CREATE A MINE: CARSON LAKE}

While the legality of the relocation of Hibbing was argued in court, Oliver Iron turned to an equally ambitious project: re-shaping a lake into a mine. Carson Lake was the largest body of freshwater within five miles of Hibbing, and before 1905, a small settlement housing a mixture of sawmill workers, miners, and recreational cabins developed along Carson Lake's eastern shore. ${ }^{46}$

By 1910, Carson Lake was surrounded by six large open-pit mines. While residents used Carson Lake for recreation and drinking water, mining companies saw the lake as a convenient repository to dispose of their growing volume of mine waste, an environmental impact that affected lakes across the Mesabi Range. ${ }^{47}$ Maps of Carson Lake from 1914 show a large waste dump produced from the Leetonia open-pit mine encroaching on the lake. These maps also show the infrastructure necessary to allow such waste dumping. Rail lines described as "Dump Tracks To Lake" run south from the mine and terminate at the north end of the lake (Figure 4.6). ${ }^{48}$ By the spring of 1914, locals expressed concern about mine waste in the lake, noting that anglers had found abnormalities in their catch. A 1914 newspaper 
article wrote, "Carson Lake was formerly a famous fishing ground at Hibbing.... There are still fish in the lake, but like those found in Torch Lake in Michigan, pollution of the water from mining operations has caused them to go blind." ${ }^{49}$ Concerns related to conservation in the Mesabi Range during the 1910s often contrasted directly with concerns related to the prosperity of the iron industry. 


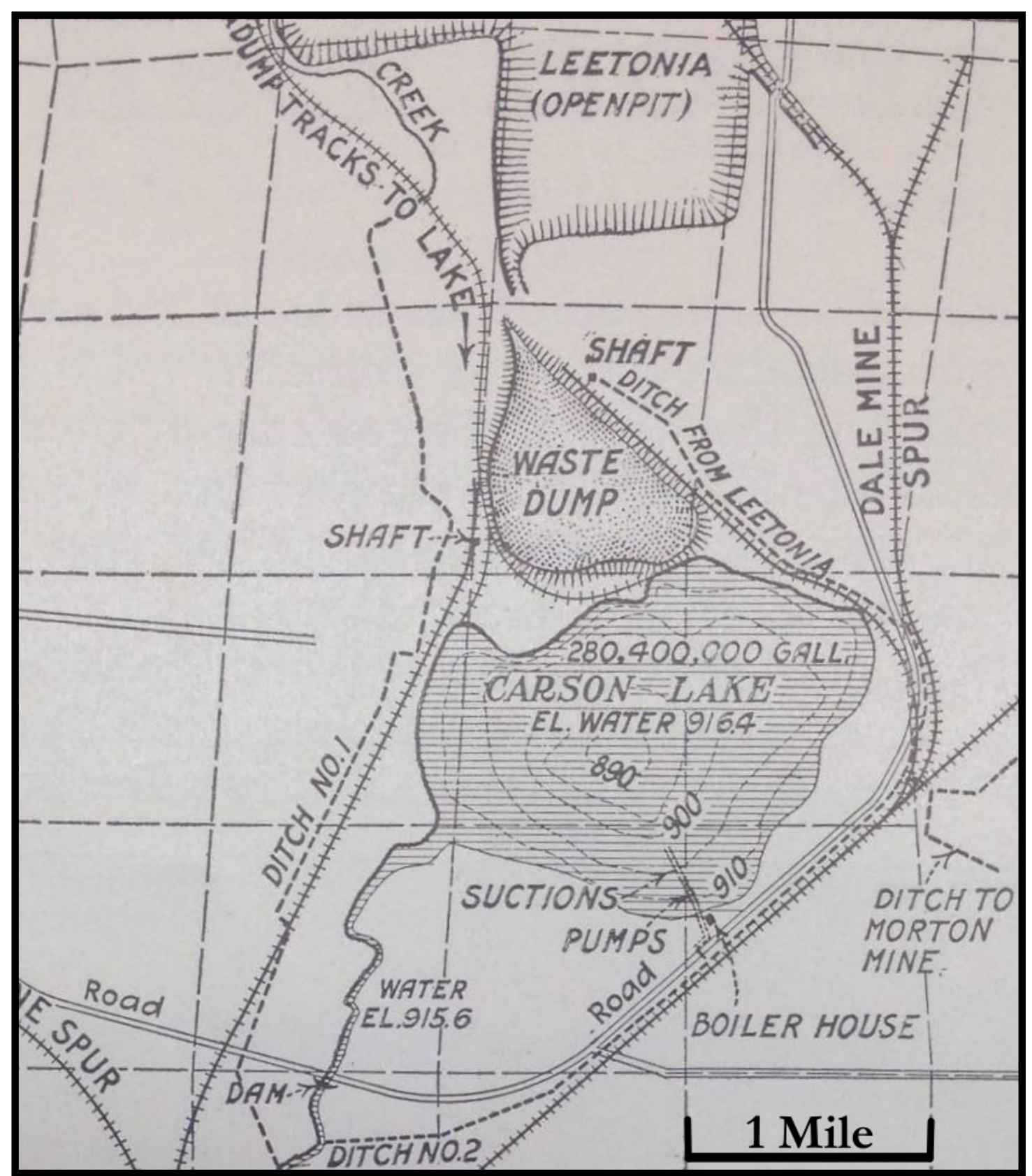

Figure 4.6: Overview of Carson Lake showing engineering plans

(Engineering and Mining Journal, 1914)

In the Mesabi Range, the majority of land was owned by either the state of Minnesota or a land-holding company, such as the Great Northern Iron Ore Properties. Minnesota began leasing mineral rights to its ore reserves during the 1890s, which provided the State with a 
taxable revenue, totaling more than $\$ 660$ million from $1890-2015 .{ }^{50}$ In Hibbing and Carson Lake, community members owned the physical properties in which they lived and worked, but the mineral rights below the surface were owned by Oliver Iron, who began purchasing these rights in the late $1890 \mathrm{~s}^{51}$

Oliver Iron began to suspect that Carson Lake might not just be a good place for mine waste dumping; it might also contain valuable ore in the lakebed. During the winter of 1912 and 1913, Oliver Iron drilled through the lake ice, retrieving core samples from the lakebed..$^{52}$ These samples verified that Carson Lake rested on a deposit of iron ore. Oliver Iron believed it could engineer a mining system to profitably remove this ore. Mining a lake presented a significant engineering challenge, specifically how best to drain the waters and keep the lakebed dry. Draining lakes to allow for mining was a novel endeavor in the Mesabi Range. ${ }^{53}$ To stir public interest in the mining operation, Oliver Iron produced a sectional model of Carson Lake which revealed the extent of ore under the lake bed - and displayed it at Minnesota state fairs. ${ }^{54}$

To drain the 280 million gallons of water from the 160-acre lake, Oliver constructed a two-mile long and eight-foot deep ditch running south from Carson Lake to the Kelly Lake lowlands in 1914. ${ }^{55}$ Oliver Iron used centrifugal pumps to dewater the lake into the ditch. As the water drained from Carson Lake, Oliver Iron realized that the lakebed was covered with a thick layer of mud, impeding their ability to develop the property as an open-pit mine, forcing Oliver to rely on underground methods. To assist in developing a more solid base upon which Oliver Iron could construct a functioning underground mine, a form of mine waste called overburden (the organic material that covered an ore body), was dumped into the lake from nearby mines. By 1916, nearly 300,000 cubic yards of overburden had been 
deposited into the Carson Lake cavity. ${ }^{56}$ By 1917, Oliver Iron had sunk a shaft to a depth of 166 feet, and by 1919 the process of lining the shaft with concrete was completed. ${ }^{57}$ Permanent equipment was erected, including a boiler and engine house, pumping station, blacksmith shop, and coal dock..$^{58}$

Nearly as soon as the Carson Lake mine began operations, it closed. The deposit Oliver found was low in grade and high in moisture "for which the company has no use at the present." ${ }^{59} \mathrm{By}$ December 1919, the pumps were turned off, the shaft house torn down, and the railroad tracks removed. The Carson Lake mine produced only 525,000 tons of ore, the minimum amount required by their mining lease.

As the mine was drained, the population of the surrounding Carson Lake community grew, to house an increasing number of miners employed by area mines. The Carson Lake community consisted of more than 60 structures by 1920, including a hardware store/post office, a pool hall, showroom, bakery, grocery, and tavern. ${ }^{60}$ By 1922, Oliver Iron had removed the largest waterbody in the Hibbing district and relocated the largest town.

Although these engineering feats generated widespread enthusiasm, they also produced protest. As residents in the region witnessed the rapid depletion of Carson Lake, attitudes shifted from fanfare to regret as a Mesabi Range "beauty spot" vanished. Sportsmen and community members complained about lost access to a recreational area "filled with fish, [(and]) a pretty shore line." ${ }^{61}$ Even though locals complained about pollution and the loss of recreational fisheries, Oliver Iron's initial success in draining Carson Lake inspired Minnesota state officials to investigate the economic feasibility of draining more lakes in the Mesabi Range, allowing for an increase in taxable revenue from the mining of other lake beds. ${ }^{62}$ 
As the focus of mining in the Mesabi Range shifted to lowergrade ores after World War II, the Pickands-Mather Co. sought to reopen the property around Carson Lake. To profitably mine the lowgrade deposit, the company required an open-pit operation. In the early 1950s, residents of Carson Lake learned of the planned mining operation (Figure 4.7). The mining company offered residents inexpensive lots near Kelly Lake, and the Carson Lake community was soon relocated two miles south. Like its namesake, the community of Carson Lake was no longer present on the landscape. ${ }^{63}$ In 1952, the Carmi-Carson Lake Mine began production, shipping more than 500,000 tons of ore. ${ }^{64}$ The mine remained in production for the next five years, and small shipments, likely from stockpiles, continued until 1977. 


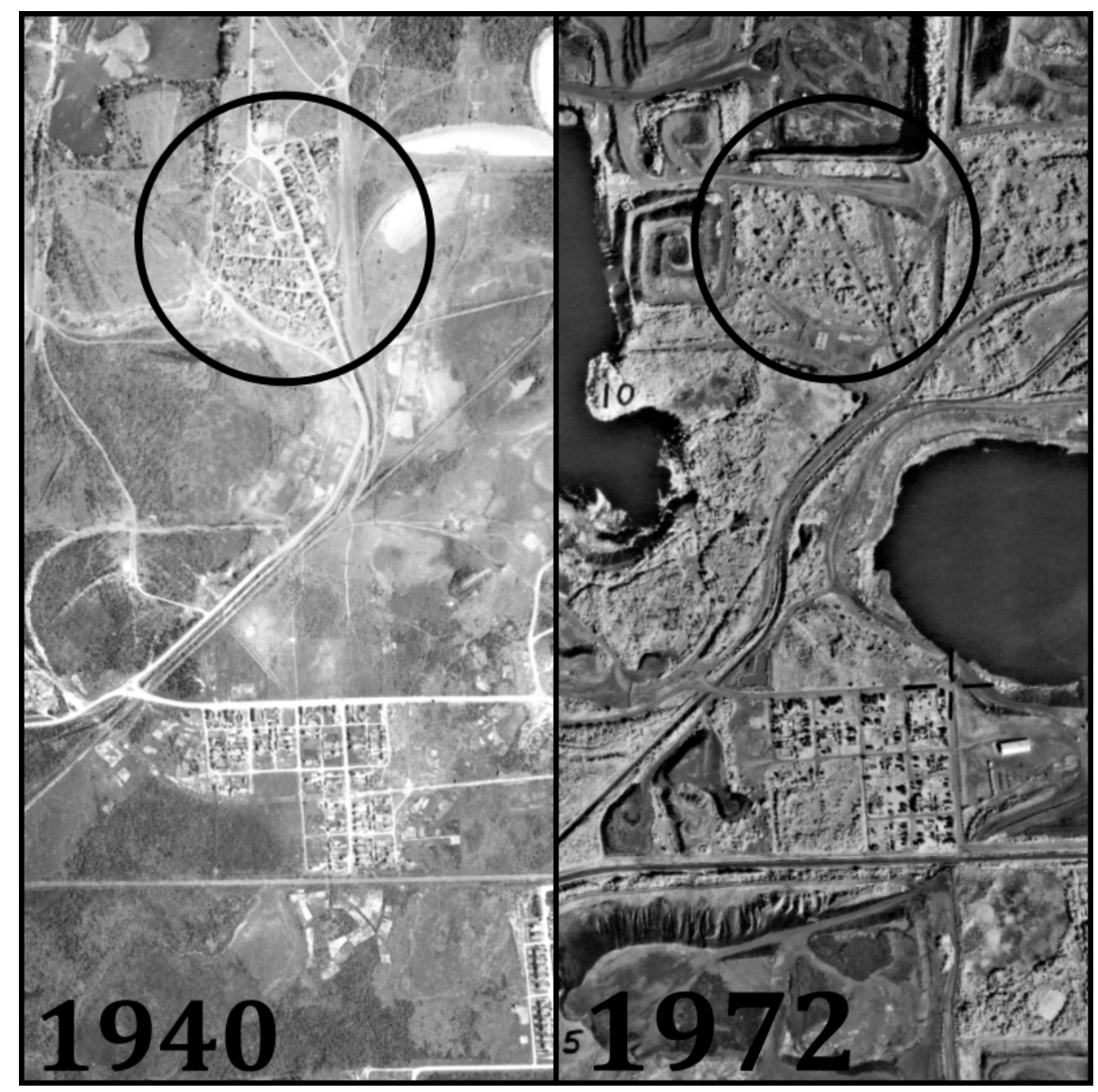

Figure 4.7: Relocation of the Carson Lake community, 1940 and 1972 (Minnesota DNR Airphotos Online)

Mining Carson Lake represented a significant engineering feat, as well as a blunder. Oliver Iron's inaccurate geological surveying led to the removal of the largest waterbody in the immediate vicinity of Hibbing. The history of the Carson Lake mine highlights the degree of political power the iron industry possessed in Minnesota and the extent to which the mining industry would go to locate and extract iron ore. Although communities voiced concerns about pollution, fish harm, and displacement, state agencies in the 1910s were intent on 
supporting the growing industry, not displaced communities or resource conservation.

\section{THE MODERN LANDSCAPE}

Oliver Iron's quest for iron during the 1910s resulted in two massive undertakings: the relocation of the town of Hibbing and the draining of Carson Lake. These two case highlight the scale of engineering efforts carried out by the iron mining industry. The actions of mining companies on the range created landscape-scale impacts, and the creation of a state agency to oversee the transition from an industrial landscape to a postindustrial, often attempted to erase them.

Due to fears over the depletion of high-grade iron ores in Minnesota in the early 1940s, the state created an agency called the Iron Range Resources and Rehabilitation Board (IRRRB), to ensure a successful economic transition for the iron ranges as they faced a post-mining future. Funded by taxes paid from iron ore shipments, the IRRRB's early economic diversification strategies sought ways to improve on taconite processing, which could help the region stay competitive with international rivals. ${ }^{65}$

During the 1970s, large open-pit mines managed by major corporations dominated the Mesabi Range, while the smaller mining operations closed and were subsequently abandoned. By 1975, an increasing number of abandoned mine lands in the Minnesota iron ranges spurred the IRRRB and the Minnesota Department of Natural Resources (MNDNR) to develop a program aimed at reclaiming and restoring these lands. In 1975 only two states were worse than Minnesota for mining reclamation. While Minnesota ranked eighth in the nation for total acreage of mine lands, it ranked 48th for reclaimed acreage. This left a landscape marked by industrial 
abandonment. ${ }^{66}$ This program, called the Mine Lands Clean-Up and Reclamation Program, functioned as a partnership between these state agencies and mining companies to promote mine site reclamation. The program removed industrial debris and structural waste from abandoned mine sites, re-vegetated barren lands, and recontoured mining landscapes in an effort to "sweep up a century of mining debris." 67

The state's efforts to reclaim portions of the mining landscape met with initial success. By the early 1980s, distinctive rust-covered piles of mine waste bore patches of green saplings, and the many tons of accumulated waste were hauled to landfills by local contractors or sold as scrap. The IRRRB worked with the MNDNR to encourage conservation programs, such as tree planting, hoping that forests would beautify the area and provide timber for future generations. Creating a tourist industry centered on the natural bounties of the Iron Range became a focus of the IRRRB during the late 1970s. ${ }^{68}$

In 1977, the IRRRB began a new program aimed at abandoned mine-pit lakes in the Mesabi Range. The IRRRB and MNDNR targeted these pit lakes as part of an accelerated fish-stocking program, where fish favored by anglers, such as trout, were added by the ton. ${ }^{69}$ To attract anglers the IRRRB promoted the unique experience of fishing in an abandoned mine, which offered anglers the "feeling of fishing in a Grand Canyon-type setting." ${ }^{70}$ The MNDNR went so far as to describe the waters of the abandoned mines as "probably the most pristine, clean water that we have in the whole state," a statement geared towards luring anglers as well as scuba divers to the region. ${ }^{71}$

The process of reclaiming mine waste and constructing a recreational landscape from an industrial one effectively erased many of the visible legacies of the range's mining heritage. These efforts directly affected potential conservation efforts aimed at the Mesabi's 
built environment, as The IRRRB removed more than 6,500 mining buildings across the Iron Range during its reclamation phase. ${ }^{72}$

In an attempt to diversify the economy and create jobs, the IRRRB sought to transform the post-industrial landscape of the Mesabi to an outdoor recreation tourism landscape. This process began with the removal of historic buildings and structures, and the revegetating of the mining landscape through reclamation programs. This was followed by the development of the Mesabi Trail, and the stocking of fish into mine-pit lakes, two successful programs that promoted a recreational vision atop the industrial landscape. While efforts to promote recreational tourism have obscured many historical features, the landscape retains much of its industrial character, in such things as open-pit mine viewing areas, and the distinctive red hills of mine waste that line Highway 169. ${ }^{73}$

Hibbing's historic business district is now part of the active Hull-Rust Mahoning mine, an open-pit more than 8 miles in total length (Figure 4.8). ${ }^{74}$ The Hull-Rust Mahoning serves two purposes, acting as a functioning mine as well as a modern tourist area. At the mine's visitor center visitors are encouraged to "go big." ${ }^{75}$ And big is what visitors encounter at the mine-viewing area. Visitors first enter through a small gift shop, followed by an open-air museum filled with massive technologies of extraction overlooking the open-pit "Grand Canyon of the North." ${ }^{76}$ Dragline buckets that could carry an elephant, truck tires as big as an above-ground swimming pool, and dump trucks that require a 17-step ladder to reach the driver's seat serve as artifacts promoting the grandeur and expansiveness of Mesabi iron mining. The open-pit chasm of the Hull-Rust Mahoning pit, which represents more than 50 individual mines that have merged into a single hole, is a product of the technological sublime, a human 
achievement that can put butterflies in the stomach even the most intrepid visitors. ${ }^{77}$

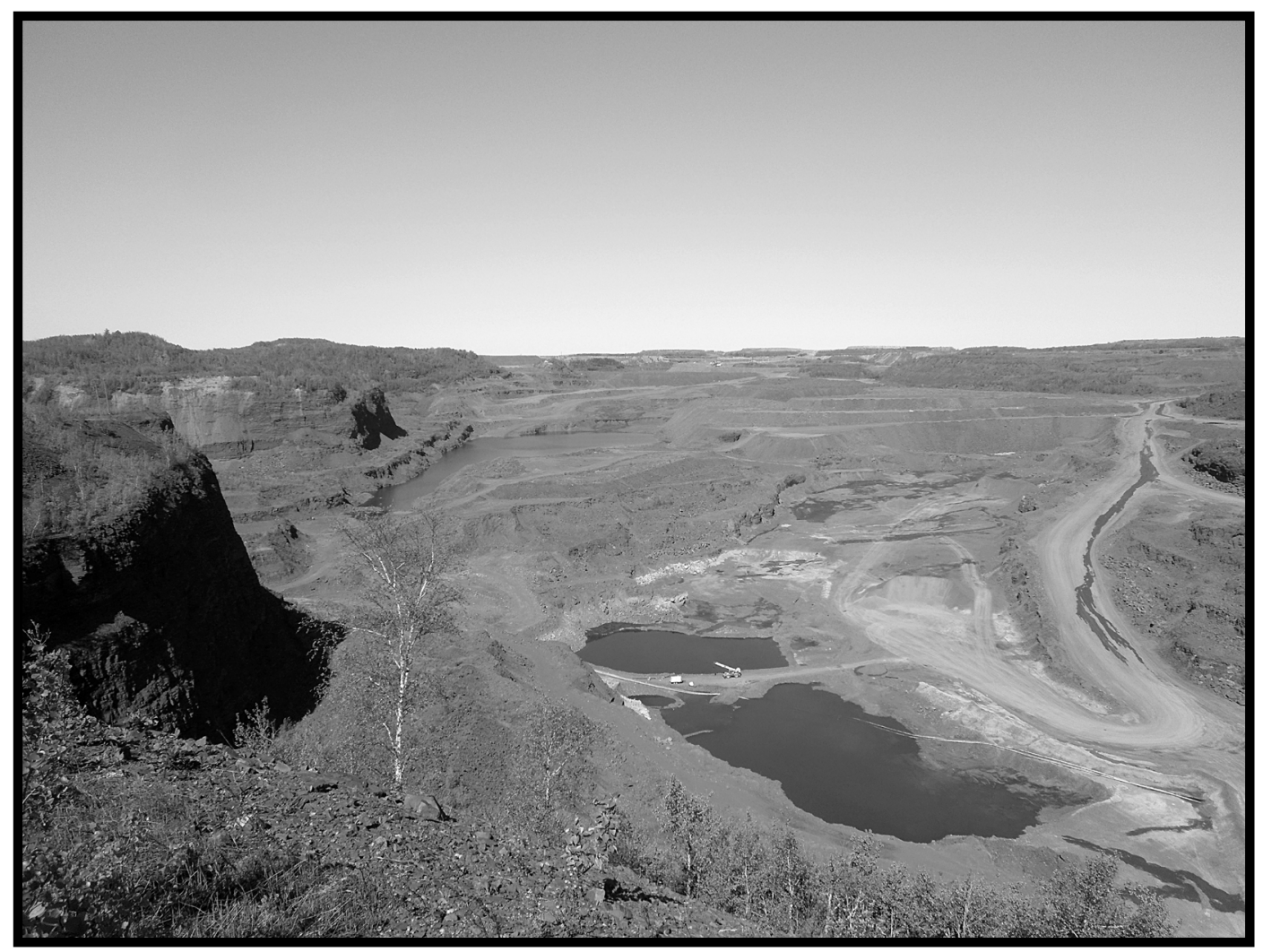

Figure 4.8: Overview of the Grand Canyon of the North (Baeten, 2015)

The road leading up to the mine viewing area follows the historical route of $1^{\text {st }}$ Avenue, the route that used to connect Alice (modern Hibbing) to Hibbing, and Hibbing to Carson Lake. Today, the road runs for 500 feet, and passes through a small section of the southern extent of historic Hibbing. Three blocks are all that remain of the original Hibbing townsite, which in 1913, had been home to 51 dwellings, a furniture warehouse, grocery, bakery, and the Lincoln High School. Holes 12-17 of the North Hibbing Disc Golf course now weave between and over the structural foundations that remain on these blocks. An interpretive sign shows images of some of the buildings that once stood here and describes the process involved in 
moving them south (Figure 4.9 and 4.10). These signs tell a story of North Hibbing and the iron industry which grew up around it. Yet the signs ignore the contentious negotiations that divided the town when Oliver Iron ordered the move.

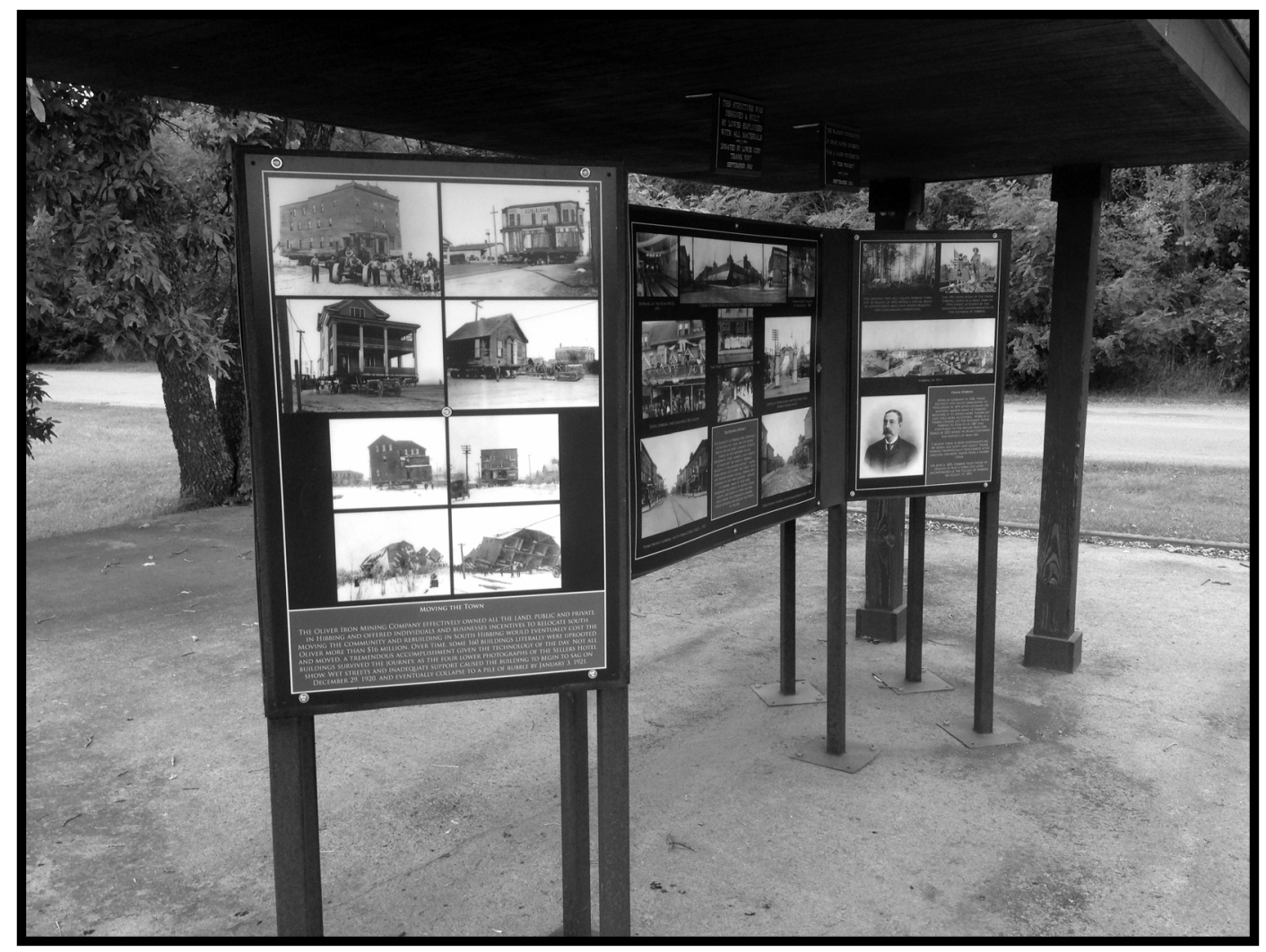

Figure 4.9: The Memorial to North Hibbing (Baeten, 2016) 


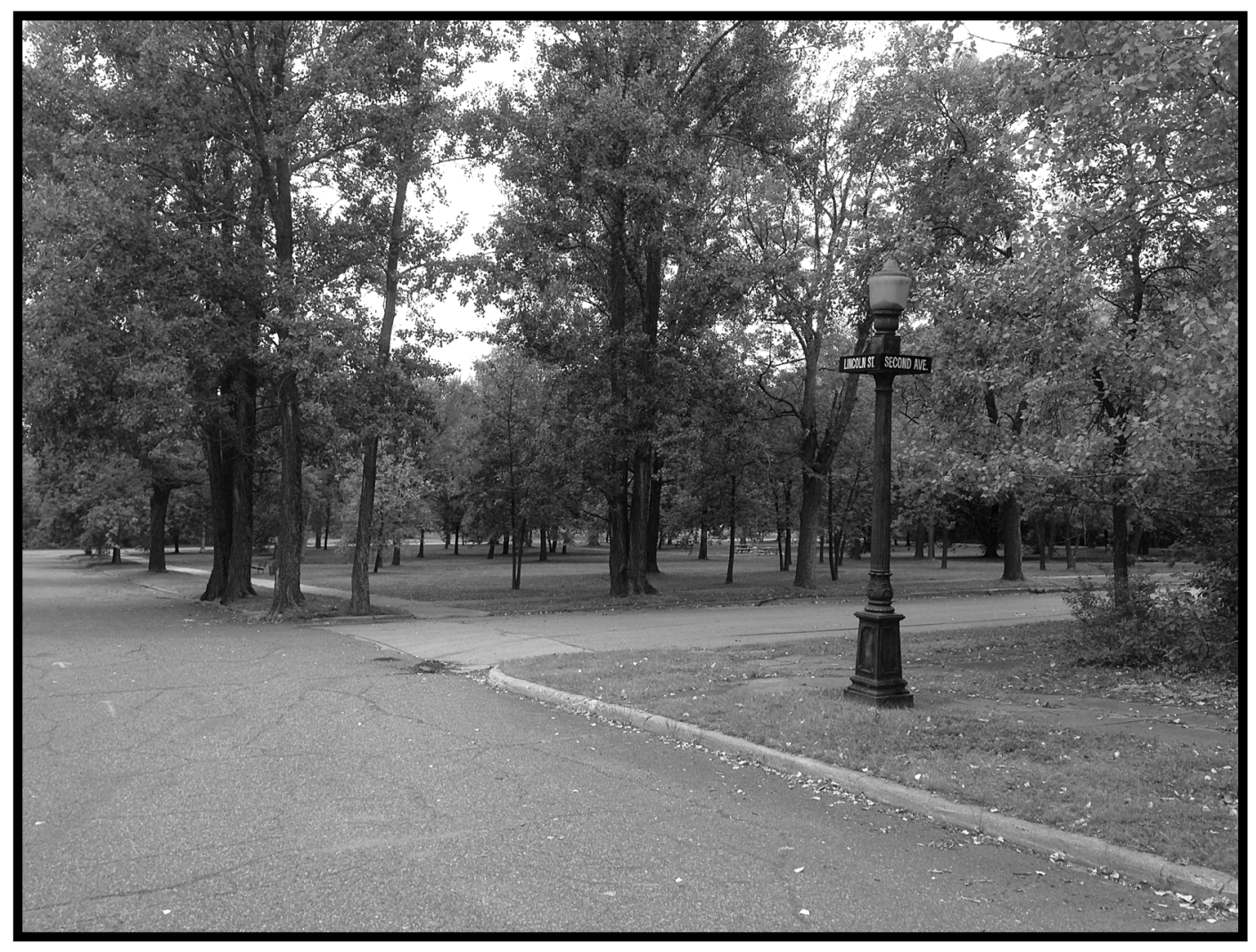

Figure 4.10: The Modern North Hibbing streetscape (Baeten, 2016)

Nearly a century after the first houses were moved from old Hibbing, the memorials built to commemorate the former community are now scheduled to be relocated to make way for the expanding Hull-Rust mine. Like the town that preceded them, the mine viewing area, the interpretive sign, and the disc golf course will soon be consumed by an open-pit mine. ${ }^{78}$

Waters removed nearly a century ago appear to be seeping through the former lakebed of Carson Lake. Today, the former Carson Lake property makes up a small section of the massive Hull-Rust Mahoning Mine. The footprint of the Carson Lake community is no longer evident on the landscape, but standing water is filling a pocket of the open-pit scar that covers the former lakebed, a reminder of the landscape change that continues to define the Mesabi Range. 


\section{CONCLUSION}

The expansion of iron mining in the Mesabi Range generated concerns from communities and the state. During the early 1900s, an increase in open-pit mining across the Mesabi Range started a long negotiation between Range communities, the iron industry and state policy makers. Larger profits by mining companies on the Mesabi Range resulted in larger open pits on the landscape. As these pits grew in size, Mesabi Range communities, such as Hibbing, had to contend with a rapidly shrinking public landscape and an increased population. To recoup some of the value lost in the removal of iron ore, Minnesota lawmakers passed a tax-system favorable for range communities, which helped fund additional public services needed for the increased population. Minnesota iron range communities were single industry towns, and this gave the iron industry added political power. The iron industry believed they were providing a public service, and if their work resulted in the displacement of a community or the removal of a lake, it was a small inconvenience to pay for the economic benefits that came with mining.

Yet, while mining waste endures for millennia, the mining industry is ephemeral. Economically accessible mineral resources are finite, and once they are gone, the communities within these mining landscapes must find new uses for these spaces. In the Mesabi Range this transformation was largely recreational; trails replaced rails and trout filled former mine pits as state agencies attempted to reclaim elements of nature from the ruins of industry. The concerted efforts of the Mine Lands Clean-Up and Reclamation Program to remove structures and associated debris at mine sites has made it difficult to identify and articulate where much of the visible mine waste in the Mesabi landscape originated, a burgeoning problem faced by every mining community. While the conservation of the built environment 
was not the primary objective of the IRRRB, the historic industrial character of the Mesabi Range remains. The IRRRB funded the development of the Minnesota Discovery Center, an historic park and research center. Additionally, the Mesabi Trail is an excellent example of the successful implementation of a rails-to-trails program and the adaptive reuse of a former industrial feature. Although they are filled with water, the abundance of mine-pit lakes possess interpretive potential, which has yet to be fully approached by heritage organizations, but may so in the future.

The expansion of open-pit iron mining in the Mesabi Range created a landscape where lakes appear where hills once existed, mine waste piles cover the foundations of former schoolhouses, and active taconite mines have dug up and blocked off access to historic thoroughfares. This paper shows that some residents of the Mesabi Range contested mine development. Future questions for scholars include: How did communities respond to and negotiate mine waste as the Mesabi shifted to lower-grade ores during the 1910s? What impact did the removal of mine buildings and mine land reclamation have on future environmental remediation and heritage concerns?

There remains a tremendous amount of value in industrial landscapes where the built environment is no longer visible. Heritage professionals have an opportunity to work with environmental specialists and community members in identifying, managing, and interpreting how these historic landscapes originated and how they continue to affect the environment and the public. 


\section{Acknowledgements:}

This work was supported by the National Science Foundation (Grant \#R56645, Toxic Mobilizations in Iron Mining Contamination). Many thanks to Dr. Nancy Langston, Dr. Don Lafreniere, and Kelley Christensen at Michigan Technological University who provided comments that greatly improved the manuscript. Thanks also to staff at the Gale Family Library of the Minnesota Historical Society for assistance gathering research materials, staff at the John R. Borchert Map Library at the University of Minnesota, and Dan Turner for access to historic Sanborn Fire Insurance maps. 


\section{Works Cited:}

1 “The Iron Ore Dilemma," Fortune, December 1945.

2 Stuart Harrison, "Where Is the Iron Ore Coming From?," Financial Analysts Journal 9, no. 3 (June 1953).

${ }^{3}$ John Baeten, Nancy Langston, and Don Lafreniere, “A Geospatial Approach to Uncovering the Hidden Waste Footprint of Lake Superior's Mesabi Iron Range," The Extractive Industries and Society, n.d., doi:10.1016/j.exis.2016.09.003.

${ }^{4}$ David A. Walker, Iron Frontier: The Discovery and Early Development of Minnesota's Three Ranges (St. Paul, MN: Minnesota Historical Society, 1979).

${ }^{5}$ Duane Smith, Mining America: The Industry and the Environment, 1800-1980 (Niwot, CO: University Press of Colorado, 1993).

${ }^{6}$ Timothy LeCain, Mass Destruction: The Men and Giant Mines That Wired America and Scared the Planet (New Brunswick: Rutgers University Press, 2009).

${ }^{7}$ Terry S. Reynolds and Virginia P. Dawson, Iron Will: Cleveland-Cliffs and the Mining of Iron Ore, 1847-2006 (Detroit: Wayne State University Press, 2011).

${ }^{8}$ Ibid.; W. Bruce Bowlus, Iron Ore Transport on the Great Lakes: The Development of a Delivery System to Feed American Industry (Jefferson, NC: McFarland \& Company, 2010).

${ }^{9}$ John Thistle and Nancy Langston, "Entangled Histories: Iron Ore Mining in Canada and the United States," The Extractive Industries and Society 3, no. 2 (April 2016): 269-77.

${ }^{10}$ Walter L. Thurman, "Waste Dumps of the Mesabi Iron Range: Heritage or Blight?" (St. Cloud State University, 1992). ${ }^{11}$ Anna Storm, Post-Industrial Landscape Scars (New York: Palgrave Macmillan, 2014); John R. Owen and Deanna Kemp, "Mining-Induced 
Displacement and Resettlement: A Critical Approach," Journal of Cleaner Production 87 (2014): 487-88; Bogumil Terminski, “MiningInduced Displacement and Resettlement: Social Problem and Human Rights Issue (A Global Perspective)," 2012.

${ }^{12}$ Richard Francaviglia, Hard Places: Reading the Landscape of America's Historic Mining Districts (Iowa City, IA: University of Iowa Press, 1991).

${ }^{13}$ Peter Goin and Elizabeth Raymond, "Recycled Landscapes: Mining's Legacies in the Mesabi Iron Range," in Technologies of Landscape: From Reaping to Recycling (Amherst, MA: University of Massachusetts Press, 1999), 271.

${ }^{14}$ Jeffery T. Manuel, Taconite Dreams: The Struggle to Sustain Mining on Minnesota's Iron Range, 1915-2000 (Minneapolis, MN: University of Minnesota Press, 2015).

${ }^{15}$ Ibid.

${ }^{16}$ Walter Van Brunt, Duluth and St. Louis County, Minnesota: Their Story and People, vol. II, III vols. (Chicago and New York: The American Historical Society, 1921).

17 "Mercer Brief of Case" (St. Paul, MN, n.d.), Davis, Kellogg \& Severance Law Firm Records, Minnesota Historical Society.

18 "Revenue Received from State Mineral Leases: FY 1890-2015"

(Minnesota Department of Natural Resources: Division of Lands and Minerals, February 2016).

${ }^{19}$ C.J. Buell, The Minnesota Legislature of 1915 (St. Paul, MN: C.J. Buell, 1915).

${ }^{20} \mathrm{Ibid}, 33$.

${ }^{21}$ Ibid, 33.

22 "Richest Village Nearly Bankrupt," Municipal Journal 39, no. 12 (September 16, 1915): 442. 
${ }^{23}$ Paul Lubotina, “The Struggle for Control of Hibbing: The People's Perspective," Upper Country: A Journal of the Lake Superior Region 2 (2014).

24 "Plucking the Goose as Town Policy," The Engineering and Mining Journal 100, no. 22 (November 27, 1915): 877-78.

${ }^{25}$ Ibid, 878; E.W. Davis, Pioneering With Taconite (St. Paul, MN:

Minnesota Historical Society, 1964), 96.

26 "Plucking the Goose as Town Policy."

${ }^{27}$ Ibid, 878.

28 "Mercer Brief of Case."

29 "Henry P. Reed Notice to Settle Case, Notice of Motion to Amend Findings, Etc., or For a New Trial” (St. Paul, MN, n.d.), Davis, Kellogg \& Severance Law Firm Records, Minnesota Historical Society.

${ }^{30}$ Lorraine De Millo, “The Moving of North Hibbing," Major Paper (Minneapolis, MN: University of Minnesota, 1976).

31 "Henry P. Reed Notice to Settle Case, Notice of Motion to Amend Findings, Etc., or For a New Trial.”

32 "Reed Affidavit” (Affidavit, St. Paul, MN, n.d.), Davis, Kellogg \& Severance Law Firm Records, Minnesota Historical Society.

${ }^{33}$ De Millo, "The Moving of North Hibbing."

${ }^{34}$ Ibid.

${ }^{35}$ Ibid.

36 "Reed Affidavit."

37 "Mercer Brief of Case."

38 "W.J. Ryder Testimony" (Testimony, n.d.), Davis, Kellogg \& Severance Law Firm Records, Minnesota Historical Society, 12. 39 “Atkinson Affidavit” (Affidavit, St. Paul, MN, n.d.), Davis, Kellogg \& Severance Law Firm Records, Minnesota Historical Society. ${ }^{40}$ Ibid. 
${ }_{41}$ "Godfrey Affidavit” (Affidavit, St. Paul, MN, n.d.), Davis, Kellogg, \& Severance Law Firm Records, Minnesota Historical Society. 42 "Olcott Affidavit" (Affidavit, St. Paul, MN, n.d.), Davis, Kellogg \& Severance Law Firm Records, Minnesota Historical Society.

${ }^{43}$ De Millo, "The Moving of North Hibbing."

${ }^{44}$ Ibid, 34.

45 “Stripping Begins on North Forty," Skillings' Mining Review 12, no. 37 (January 26, 1924).

${ }^{46}$ Rodney Halunen, "Ghost Towns and Locations of the Mesabi and the Inter-Urban Electric Line” (A “Plan B” Paper, University of Minnesota, 1966).

${ }^{47}$ L.D. Davenport, "Unwatering Carson Lake," The Engineering and Mining Journal 98, no. 25 (December 19, 1914): 1069-70. ${ }^{48}$ Ibid.

49 “Oliver Iron Mining Company Will Fill In Carson Lake," The Virginia Enterprise, May 15, 1914.

50 "Revenue Received from State Mineral Leases: FY 1890-2015."

51 “The Lake Superior District," The Iron Trade Review 66 (1920).

52 “Kerr Open Pit," Skillings' Mining Review 5, no. 27 (November 25, 1916): 7.

53 “The Draining of Carson Lake," The Engineering and Mining Journal 97, no. 10 (March 7, 1914): 536.

54 "Draining of Carson Lake," Engineering and Mining Journal 96, no. 10 (September 6, 1913), 536.

55 "Oliver Iron Mining Company Will Fill In Carson Lake."

56 "Kerr Open Pit."

57 “Carson Lake Mine Closes Down,” Skillings' Mining Review 8, no. 31 (December 20, 1919): 8. 
58 "Carson Lake and Vicintiy," Oliver Iron Mining Co. Mapbook (Oliver Iron Mining Co., January 1, 1920), Iron Range Research Center.

59 "Carson Lake Mine Closes Down."

${ }^{60}$ Halunen, "Ghost Towns and Locations of the Mesabi and the Inter-

Urban Electric Line."

${ }_{61}$ "Oliver Iron Mining Company Will Fill In Carson Lake."

62 "Would Reclaim Iron Ore Under Lakes," The Labor World, August 11, 1917.

${ }^{63}$ Halunen, "Ghost Towns and Locations of the Mesabi and the InterUrban Electric Line."

64 "Pickands Mather \& Co. Production Totals," Skillings' Mining Review 41, no. 52 (April 4, 1953).

${ }^{65}$ Occupation Tax on Producing Ores, Chapter 544, vol. H.F. No. 948, 1941; Manuel, Taconite Dreams: The Struggle to Sustain Mining on Minnesota's Iron Range, 1915-2000.

${ }^{66}$ Pam Leschak, "Big Clean-Up on the Iron Range," The Minnesota Department of Natural Resources Conservation Volunteer, October 1977.

${ }^{67}$ Ibid.

${ }^{68}$ Manuel, Taconite Dreams: The Struggle to Sustain Mining on Minnesota's Iron Range, 1915-2000.

${ }^{69}$ Ray Svatos, "Fishing Minnesota's Abandoned Iron Pits," The Minnesota Department of Natural Resources Conservation Volunteer, August 1986.

${ }^{70}$ Ibid.

${ }^{71}$ Margaret Haapoja, "A New Window on the Range," The Minnesota Department of Natural Resources Conservation Volunteer, June 2001. ${ }^{72}$ Manuel, Taconite Dreams: The Struggle to Sustain Mining on Minnesota's Iron Range, 1915-2000. 
${ }^{73}$ Goin and Raymond, "Recycled Landscapes:Mining's Legacies in the Mesabi Iron Range."

${ }^{74}$ Frank Jaksa, "Grand Canyon of the North," The Minnesota

Department of Natural Resources Conservation Volunteer, June 1989. 75 "Mine View and Other Scenic Overlooks," Iron Range Tourism, n.d., ironrange.org/attractions/\#ctg_overlooks.

${ }^{76}$ Jaksa, "Grand Canyon of the North."

${ }^{77}$ David Nye, American Technological Sublime (Cambridge, MA: The MIT Press, 1994).

${ }^{78}$ Kelly Grinsteinner, "Hibbing Disc Golf Site Faces Limited Future," Mesabi Daily News, May 2, 2016. 


\title{
Chapter 5: Negotiating Mobile Mine Waste: Environmental Legacies of Low-Grade Iron Ore Mining in Minnesota's Mesabi Range ${ }^{1}$
}

\begin{abstract}
:
Beginning in 1910, new technologies for mining and processing low-grade iron ore created novel environmental challenges for Minnesota's iron mining communities. Unlike earlier high-grade iron ore which required little processing before shipping, low-grade iron ore required extensive processing near mining sites, and that processing created vast quantities of finely-ground tailings that mobilized into nearby streams, lakes, and communities. In Lake Superior's Mesabi Range, low-grade iron ores brought significant economic benefits, but they were coupled with equally significant environmental transformations. Using an envirotechnical framework, this paper asks: how did communities in the Mesabi Range respond to new environmental challenges from low-grade iron ore? How did these negotiations between Mesabi communities, mining companies and the state play out in the courts? How did these court battles shape state mining policy? How have local communities remembered and memorialized these environmental legacies? I argue that by 1913 mining communities in the Mesabi Range began to contest the environmental impacts that came with the shift to low-grade ore mining, and these negotiations remain embedded in the current landscape but forgotten from collective memory, due to a succession of mining efforts and a lack of heritage recognition.
\end{abstract}

1 This chapter was submitted to Environmental History as: John Baeten, "Negotiating Mobile Mine Waste: Environmental Legacies of Low-Grade Iron Ore Mining in Minnesota's Mesabi Range" 


\section{Introduction:}

Beginning in 1847, iron mining boomed in the Lake Superior District, and by 1890 the region had become the largest producer of iron ore in the world (see Figure 5.1). While iron mining brought a great deal of wealth to communities in the Lake Superior District, it also produced vast and lasting environmental impacts. In Minnesota's Mesabi Range, the visible environmental footprint from early iron mining was largely confined to the mines themselves. The iron ores that early miners were extracting were of a high enough grade that they could simply be mined and transported to lower Great Lakes smelters without further processing. For mining communities, this meant that the visible impacts of mining largely remained at the mine locations, allowing for a separation between residential communities and the waste produced during mining operations. 


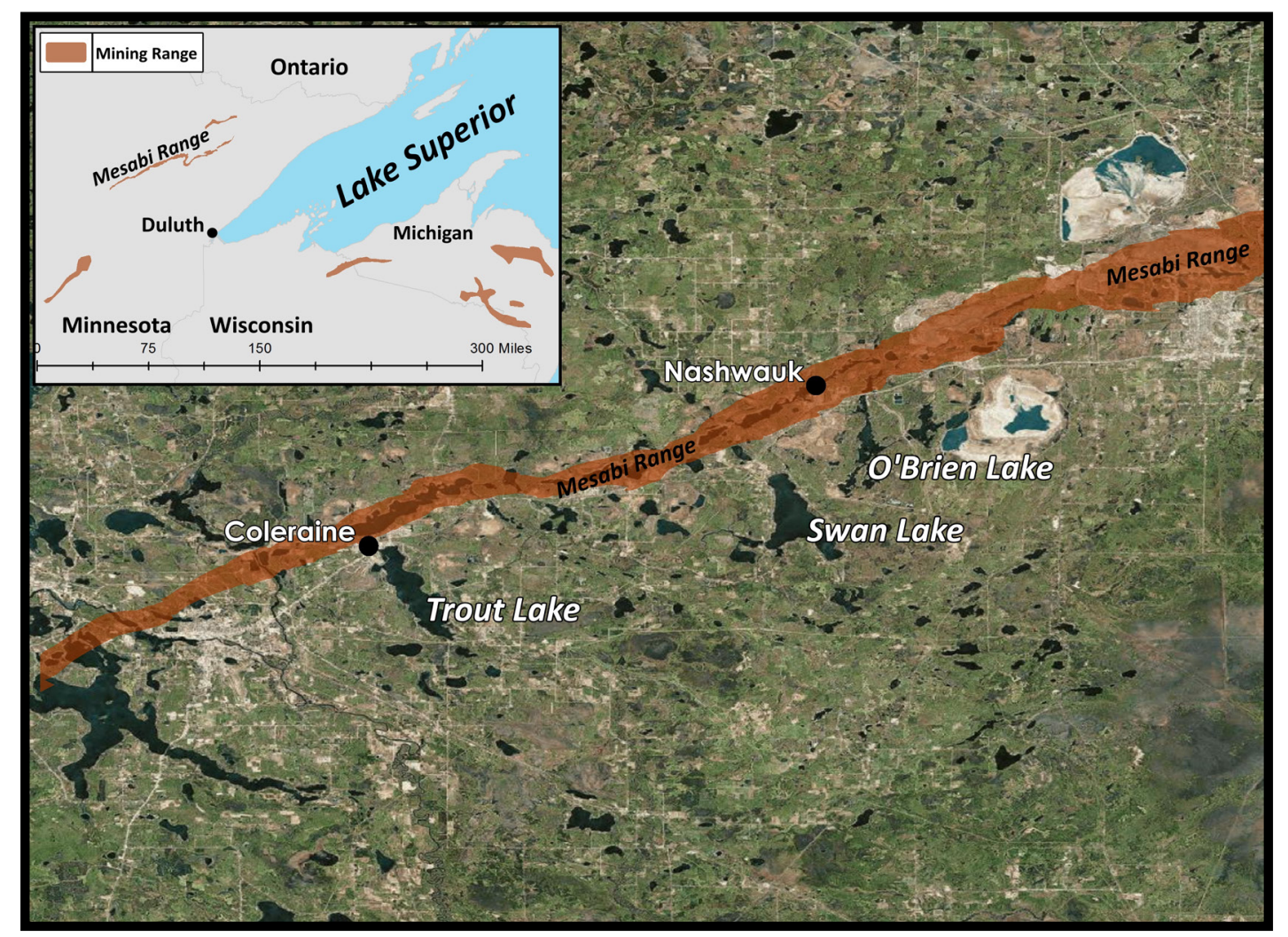

Figure 5.1: Overview of the Lake Superior Iron District and the

Western Mesabi Range

In 1910, the advent of low-grade iron ore mining and concentration in the Mesabi Range changed the relationship between mining waste and communities. A new mining technology called "beneficiation" allowed for the profitable mining of low-grade iron ores. Low-grade ores required extensive processing at beneficiation plants near the mines before they could be shipped, a process that resulted in the creation of an abundance of mobile mine waste called tailings. Finely ground tailings could migrate far from their point of disposal, making their way into both the waters and the air of nearby residential communities. This meant that the waste footprint and water quality impacts from mining began to spread from industrial mine sites into residential communities. 
Community members recognized that the economic benefits of mining had led to an improved quality of life in the Mesabi Range. Jobs in the mines supported families and a commercial sector, while taxes on mining revenues supported good schools and civic infrastructure. Yet mining was beginning to literally undermine many of those amenities, when all but two communities on the Mesabi Range were forced to relocate as open-pit mines expanded. ${ }^{1}$ By 1913, communities were already struggling to balance economic benefits with the environmental costs that came with expanding mining and ore processing.

Using an envirotech framework, this article asks: how did Minnesota's iron range communities negotiate the mobile waste produced by the mining and processing of low-grade iron ore? When did community members contest pollution from mining, and when did they accept it as a cost of doing business? How did the state of Minnesota respond to these concerns? How do local heritage organizations today memorialize the environmental legacies of lowgrade iron ore mining and processing?

\section{Mining stages in the Mesabi Range:}

Since 1890, the iron mines of the Lake Superior District have been the top producers of iron ore in the United States. Consisting of

six iron ranges that span across three states, Michigan, Wisconsin, and Minnesota, the Lake Superior District contained North America's greatest source of iron ore. The period following the Civil War witnessed an expansion of industrial development in North America, and this required steel, most of which was produced using the iron ores mined in the Lake Superior District. ${ }^{2}$ By 1890, American steel 
mills purchased more than 50\% of their iron ore from the Lake Superior district, and by the end of World War II, the District's mines accounted for $85 \%$ of the nation's iron ore production. ${ }^{3}$ Beginning in 1893, the mines of the Mesabi Range quickly grew in national importance, and by 1900, Mesabi mines became the dominant producers of the Lake Superior District.

Iron mining in the Mesabi Range underwent three technological phases. The first iron mines on the Mesabi Range opened in the 1890s and consisted of high-grade direct shipping ores. ${ }^{4}$ High-grade direct shipping ore reached its peak in the 1940s, and began to decline by the 1950s. The second phase began in 1910 with the mining of lowgrade washable ores, which continued into the 1980s. The third phase began in 1957 with taconite mining, the lowest grade of iron in the Lake Superior District, which continues into the $21^{\text {st }}$ century. ${ }^{5}$ Each of phase of mining produced environmental impacts, evident in the creation of hundreds of deep, open-pit excavation, but they differed in both their scale and spatial extent. Unlike the mining of direct shipping ores, the mining and processing of low-grade washable ore and taconite produced a novel and mobile form of mine waste, called tailings, which often mobilized far from the mines themselves.

Although iron mining has often been portrayed as being less toxic than either coal or sulfide-copper ore mining, the environmental impacts of iron mining in the Lake Superior basin have resulted in a long history of public concern and environmental change. John Thistle and Nancy Langston argue that the environmental impacts produced from taconite mining and processing resulted in widespread impacts that required legal intervention to alleviate. ${ }^{6}$ The most prominent legal case in the Mesabi Range involved the asbestos-laden tailings discharged from the Reserve Mining Company's Silver Bay taconite 
plant on the western shore of Lake Superior. Reserve's Silver Bay taconite plant used Lake Superior as a massive sink for the plant's tailings disposal for twenty-five years, and resulted in a groundbreaking federal ruling in the 1970s. ${ }^{7}$

The tailings produced from washable ores in the Mesabi Range did not produce the same impacts seen in the processing of sulfide copper ores of the American west, or the taconite tailings dumped into Lake Superior. Yet washable ore processing did ignite public outcry and resulted in the first legal case filed against a Mesabi Range mining company's practice of dumping tailings. The processing of washable ores physically transformed much of the Mesabi Range, and the wastes they created have persisted on the landscape long after the processing plants that produced them.

\section{Envirotech perspectives on mining:}

Recent envirotech scholarship focused on the intersection of environmental history and the history of technology has broadened our understanding of the relationship between technological systems and the environment in the shaping of historical mining landscapes. ${ }^{8}$ Historians Duane Smith and Richard Francaviglia show that by 1900, open-pit mine excavations began to replace shaft houses as the prototypical landscape feature of American mining landscapes from Michigan to Montana. ${ }^{9}$ Timothy LeCain's study of "mass destruction" technologies, such as the steam shovels used in the copper mines of Utah and Montana beginning in the early 1900s, highlights how developments in extractive technologies provided mining companies with the economy of speed and scale necessary for the profitable extraction of low-grade ores. ${ }^{10}$ 
Daviken Studnicki-Gizbert and David Schecter examine how the processing of low-grade ores produced tremendous environmental change, such as the deforestation of timber stands to be used as a fuel source for smelting operations. ${ }^{11}$ Bode Morin, Fred Quivik, and Marianne Sullivan show that the processing of sulfide ores at smelters resulted in the emission of sulfur dioxide into the atmosphere, which affected human, animal and plant life. ${ }^{12}$ These technological systems did not develop in a vacuum, as shown by historians David Walker and Jeffrey Manuel. Terry Reynolds and Virginia Dawson have examined the economic and political systems that allowed for iron mines to develop and expand within Marquette range of the Lake Superior District. ${ }^{13}$

Studies exploring the historical importance of waste and contamination have shown that the environmental legacies wrought by low-grade ore mining possess important cultural significance. ${ }^{14}$ Quivik's study of the physical components used to contain tailings, slag, and other mine wastes elucidates how these technological systems depict the "contested terrain" that occurred within the historical mining landscape between community members, the mining industry and the state over how to manage mine waste. ${ }^{15}$ Archaeologist Donald Hardesty believes that the value of mine waste and toxicity should be considered under a "socially redeeming" framework, arguing that industrial wastes covey "the impact of industrial technologies upon workplaces, communities, and landscapes." ${ }^{16}$

Studying the environmental persistence of abandoned mines, Arn Keeling and John Sandlos' research illuminates the legacy effects of industrial waste within post-mining landscapes found in Northern Canada. ${ }^{17}$ Keeling and Sandlos argue that these abandoned mines 
produced "legacies that continue to haunt both the memories and the biophysical environments of local communities." ${ }^{18}$ Historical geographer Craig Colton refers to the legacy features found in historical mining landscapes, such as tailings, waste rock, and overburden piles, as a "technological by-product" of the mining industry, landscape features emblematic of a region's industrial past. ${ }^{19}$

\section{The Development of Low-Grade Ores:}

Mining in the Mesabi Range began in 1893, and for the next seventeen years only high-grade iron ores were mined in the region, and no tailings were produced. In 1910, the first shipment of lowgrade washable ore arrived at U.S. Steel's Trout Lake concentrator, and the first tonnage of tailings were soon dumped into Trout Lake (see Figure 5.2). The Trout Lake concentrator was the first beneficiation plant on the Mesabi Range, and its successful beneficiation of lowgrade ores prompted other mining companies to invest in similar lowgrade iron ore technologies. 


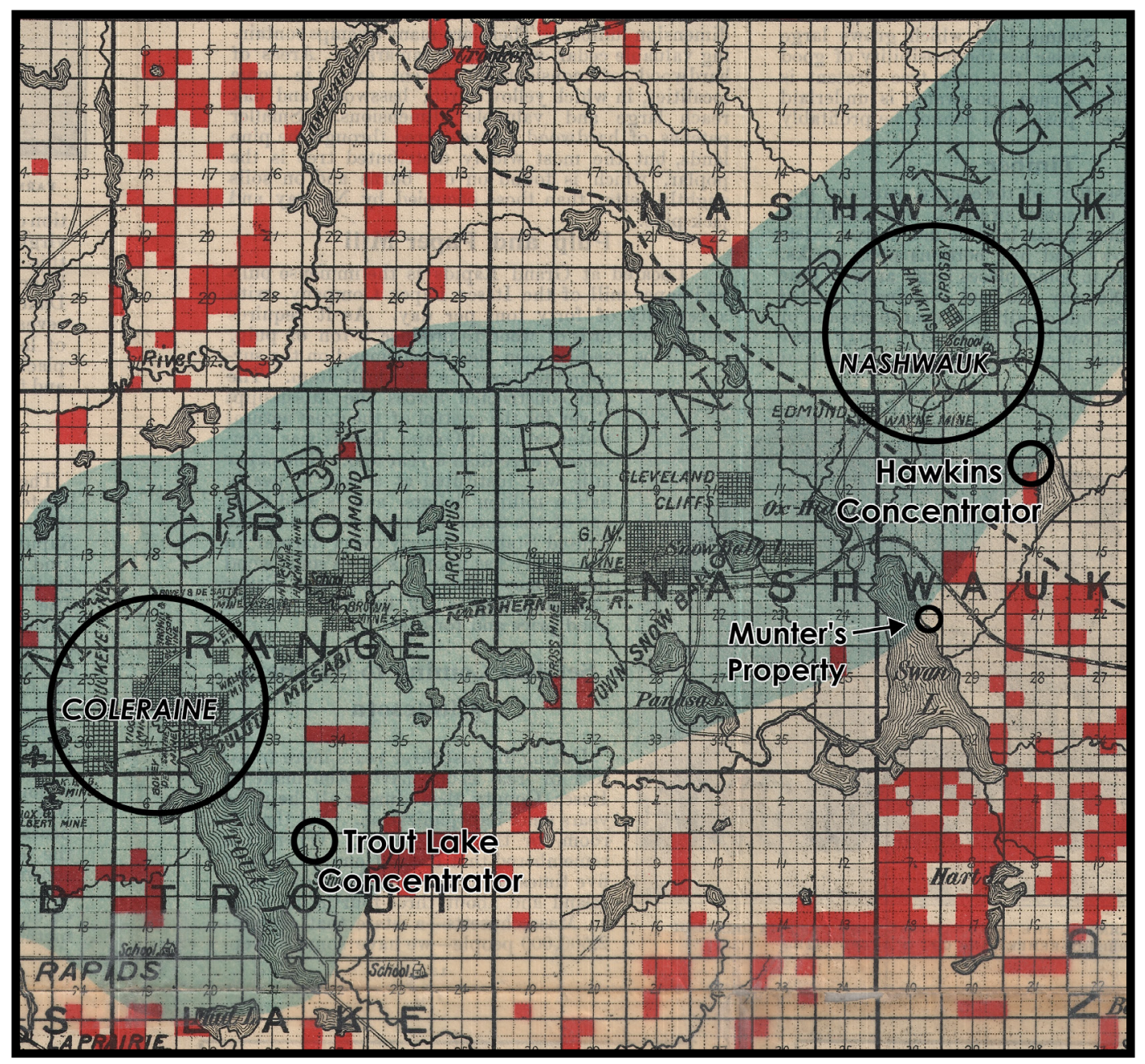

Figure 5.2: Overview of the Western Mesabi Range, showing the locations of the Trout Lake and Hawkins Concentrators (Adapted from the map "Itasca County, Minnesota: Cheap Homes for Thousands", Reishus-Remer Land Co., 1908, University of Minnesota Libraries, John R. Borchert Map Library).

In 1911, Wisconsin Steel (the mining branch of International Harvester) developed plans to construct their own beneficiation plant, the Hawkins concentrator at Nashwauk, MN, fifteen miles from US Steel's plant at Coleraine. The Hawkins concentrator was built to process the washable ore from Wisconsin Steel's Hawkins mine, located two miles northwest of the plant (see Figure 5.3 and 5.4). The Hawkins mine had been the first operating mine in the Western 
Mesabi Range, shipping its first carload of higher-grade ore in 1902. At the Hawkins mine, like most mines in the Western Mesabi, lowgrade washable ores were found interspersed with high-grade direct shipping ores, and mining engineers with Wisconsin Steel noted an abundance of low-grade washable ore throughout their property.

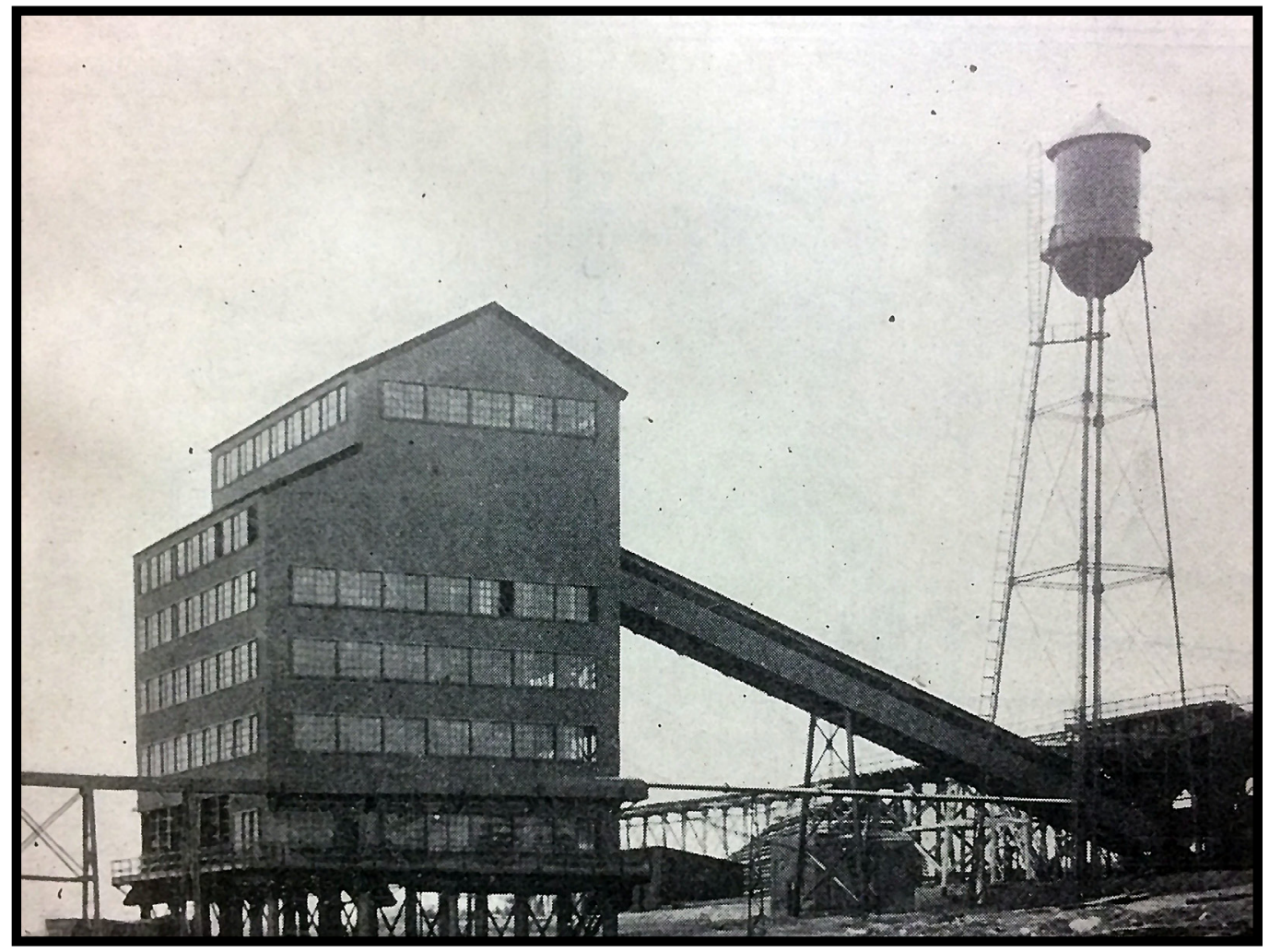

Figure 5.3: The Hawkins concentrator ("Ore Washing Plant of the Wisconsin Steel Co.”, Mining and Engineering World, July 13, 1912). 


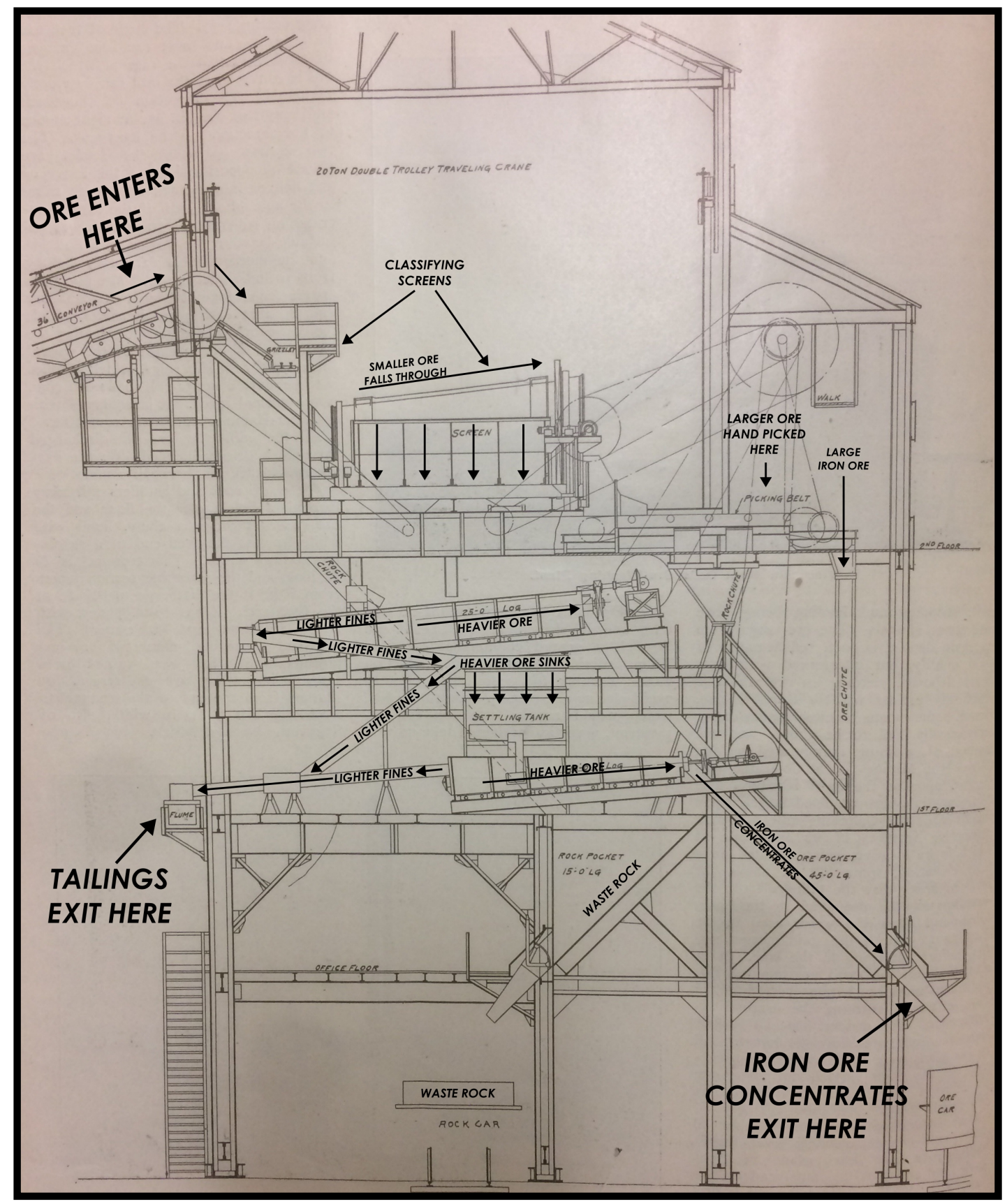

Figure 5.4: Cross section of the Hawkins concentrator, showing beneficiation process (Adapted from, "Ore Washing Plant of the Wisconsin Steel Co.”, Mining and Engineering World, July 13, 1912) 
Located adjacent to the Hawkins mine was the town of Nashwauk. Before 1903, logging functioned as the primary industry around Nashwauk, and the townsite had been settled as a logging camp. When logging companies moved on, Nashwauk persisted, owing to the development of mining in the Western Mesabi. With the opening of the Hawkins mine, Nashwauk began to grow, and in 1903 it became the first incorporated town in the western Mesabi.

More than 265 lakes and small ponds are located within the stretches of the western Mesabi, and the location of these waterbodies functioned as important factors in the locating of beneficiation plants. Mining companies relied on lakes for both the water used in ore concentration and as a place to dump tailings. In choosing a location to place their Hawkins concentrator, Wisconsin Steel needed to identify a lake located near the Hawkins mine, which would limit the distance the ore needed to travel. This waterbody also needed to be large enough to provide water for ore concentration and to hold the concentrator's continual flow of tailings. Near Nashwauk, there were two such lakes: O'Brien Lake, located roughly two miles southeast of the Hawkins mine, and Swan Lake, located 3.5 miles to the south. Wisconsin Steel ultimately chose the northwest shore of O'Brien Lake to construct its concentrator.

Following the purchase of the property on O'Brien Lake, Wisconsin Steel began buying up the majority of the lake's surface properties..$^{20}$ Because the Hawkins concentrator would be using O'Brien lake as both a source of water for industrial purposes and as a place to dump its mine waste, Wisconsin Steel recognized that purchasing the majority of the lake's surrounding surface properties could ultimately lessen the probability of disruption from other land owners. 
O'Brien Lake is part of a chain of lakes, connected by O'Brien Creek, whose headwaters originate just east of Nashwauk. O'Brien Creek runs generally north-south for just under seven miles, first feeding into O’Brien Lake, followed by Little O’Brien Lake, and finally emptying into Swan Lake, a popular resort destination for Mesabi Range communities. By purchasing the lots that surrounded O'Brien Lake, Wisconsin Steel attempted to curtail any potential concerns that might arise from the operation of the Hawkins concentrator, however, their tailings disposal method was met with almost instant public disapproval. The broader O'Brien Lake ecosystem and the linkage of O’Brien Lake with Swan Lake by O'Brien Creek were problems that Wisconsin Steel's engineers failed to account for when designing the Hawkins concentrator. And in 1913, it was along this route that the tailings produced at Wisconsin Steel's Hawkins concentrator traveled.

\section{The Problem with Tailings:}

On January 31, 1914, the Engineering and Mining Journal published an editorial describing a problem with the tailings produced at the Hawkins concentrator. ${ }^{21}$ These tailings had become "possessed of a wanderlust" as they began to migrate from their point of discharge and moved into Swan Lake, a larger lake downstream of O’Brien Lake. Upon entering Swan Lake, the "red coloring power of a little hematite slime" changed Swan Lake to the "color of that slow poison known as 'Dago Red'." 22 The discoloring of Swan Lake "dismayed and disgusted" a handful of publicans (tavern owners) who had summer cabins on the lake, and "they or their lawyers are said to have sued the Wisconsin Steel Co... alleging infinite damage to their valuable property holdings." 
A year earlier, in the spring of 1913, John Munter, a publican and resident of Hibbing, had traveled to his cabin on the northeast shore of Swan Lake (see Figure 5.2 above). He had been horrified to see that the lake had turned red. Known as a Mesabi beauty spot, Swan Lake is located roughly 5 miles southwest of Nashwauk and has functioned as a retreat destination from the early 1900s to today. ${ }^{23}$

Munter believed that he had a legal right for his property and the surrounding environment to remain in the same physical condition as when he first purchased the property. The discoloring of Swan Lake changed this. Distraught, Munter sought legal counsel, contacting Victor Power, a Hibbing attorney with a track record of taking on some of the Mesabi's most powerful mining companies. Power filed an injunction in June 1913 against Wisconsin Steel and its use of the Hawkins concentrator to process washable ores. ${ }^{24}$

Munter's injunction listed nineteen separate complaints against Wisconsin Steel and its use of the Hawkins concentrator. The injunction called for Wisconsin Steel to be legally restrained from operating their Hawkins Plant in a manner that would lead to the waters of Swan Lake becoming "contaminated, polluted and discolored by the dumping of iron ore or washings." ${ }^{25}$ Munter argued that the discoloring of Swan Lake made the water unfit for drinking, bathing, or cutting ice. Munter had purchased his property because of Swan Lake's "natural scenic beauty," and he claimed that the value in his Swan Lake property came from the "clearness of its waters, the fineness of its beaches," elements jeopardized by the tailings migrating from the Hawkins plant. ${ }^{26}$

Munter's suit argued that Wisconsin Steel operated its Hawkins plant with extreme negligence. The company acted with an "utter disregard" for the property rights of downstream landowners. The 
injunction argued that alternatives existed, so the company had no need to dump tailings where they "will contaminate the waters of O’Brien and Swan Lake." ${ }^{27}$

On June 9, 1913, Munter filed an affidavit, in which he expressed grievances listed in the injunction. Munter's claims were affirmed by the affidavits of three other Swan Lake property owners, Nels Olander, C.E. Anderson, and Sarah McCauley. ${ }^{28}$ A primary factor in the injunction was the role that color played in the ability to perceive pollution and environmental change. People assumed that clear water equated with purity and cleanliness, while discolored or darkened waters implied pollution. ${ }^{29}$

Wisconsin Steel assembled a defense led by the Kellogg and Baldwin law firm of St. Paul and Duluth. The company sought affidavits from prominent employees of the Hawkins mine, Wisconsin Steel Co. and International Harvester, and solicited support from local community members. Joseph Sellwood, general manager of Wisconsin Steel's mining operations in Minnesota, served as the primary voice of the defense for the extent of the court case. Sellwood and others testified that the waters of Swan Lake had always been discolored and dark, and that its waters were "impure and are not and never have been fit for drinking purposes." ${ }^{30}$ Sellwood also questioned the merit of the injunction, arguing that none of the plaintiffs used the waters of Swan Lake for so-called beneficial uses-namely those that provided economic benefits, such as the operating of a sawmill, or the watering of livestock. Rather, residents only enjoyed the lake for pleasure-by implication, not a beneficial use. Further, Sellwood argued that any discoloration that occurred from the Hawkins' concentrator caused no real harm to Swan Lake, claiming that the fish 
were healthy and not affected, and that no staining of the body occurred after bathing in its waters. ${ }^{31}$

Both the defendant and the plaintiff used the coloring of the waters of Swan Lake as primary evidence. The company argued that Swan Lake was fed by a swamp and was always murky and unfit for consumption, while the plaintiff claimed that it was a clean, clear lake, naturally suited for domestic purposes. Yet, what evidence could either use to support their claims regarding the lake's color in 1913 ? Although there were some limited color photography technologies available for commercial purposes by 1913, accessible color photographing products, such as Kodacolor film, wouldn't be developed for another three decades. To show the court either the discoloring of Swan Lake's water, or the lack there of, bottles of water were collected from Swan Lake by both the plaintiff and the defense.

On June 27, 1913, B .W. Batchelder, the superintendent of the Hawkins mine, visited Swan Lake to inspect claims filed in the injunction. Batchelder rented a boat and collected five samples of water from Swan Lake, one directly in front of Munter's property, another in front of the affiant Nels Olander's property, and a third roughly 1,000-ft offshore of where O'Brien Creek enters into Swan Lake. Batchelder hoped that these samples would show that Swan Lake's waters had not been discolored..$^{32}$ Batchelder also met with a State Game Warden who had collected water samples from O'Brien Lake and who assured Batchelder that the Hawkins concentrator was "not interfering with or injuring the fish in said O'Brien Lake." ${ }^{33}$ The warden implied that if fish in the lake where the Hawkins plant was directly dumping its tailings were healthy, then fish downstream could not have been harmed by that waste. Batchelder returned to Swan 
Lake two more times for samples, and the plaintiff collected samples as well. ${ }^{34}$

Whose samples were more persuasive? The plaintiff argued from his samples that the lake had been clean before the plant opened, while the defendant argued the lake had always been dirty. While we cannot say for certain, the Minnesota DNR currently classifies Swan Lake as a Class 22 lake, meaning it is "generally clear, large, very deep." This is a stark contrast from Wisconsin Steel's swampy and stagnant portrayal of Swan Lake. ${ }^{35}$

In his August 1913 affidavit, Sellwood denied all charges made by Munter and downplayed any environmental impacts caused by the Hawkins concentrator as trivialities that came with the tremendous economic benefits that his company and ore processing brought to the area and broader nation. But he implicitly recognized the harm done when he added that with the benefits of industrial prosperity came the inevitable consequences of environmental pollution. ${ }^{36}$ If the residents of Nashwauk and the citizens of the United States wanted good jobs and modern amenities, environmental quality had to suffer.

During the summer of 1913, Wisconsin Steel employed between $30-40 \%$ of all men within the Nashwauk area, allowing Sellwood to argue that a disruption to mining and ore washing would cause tremendous hardships for the community. Sellwood added that the mining industry had civilized the Mesabi Range. Before the industry arrived, the region was a "wild, unsettled territory" where "there were no settlers, except here and there one living in the woods." ${ }^{37}$ Wisconsin Steel relied on this rhetoric throughout the court case, threatening that if the injunction was approved and the court found the mining company guilty, the industry would collapse and the western Mesabi would revert to a wild and unsettled place. 
In court, Sellwood claimed that the plant needed to be located on the lake because water was essential for the processing technology. No place other than O'Brien Lake or Swan Lake was “available for such purposes of washing, and if said washing plant is shut down, said mine will be very greatly depreciated in value and damaged." ${ }^{38}$ While Sellwood's threats that the mine would shut may have been exaggerated, Wisconsin Steel had made significant economic investments in developing its low-grade ore business, including taking a 20-year lease on the Hawkins mine in 1912, constructing the concentrating plant, and purchasing over $90 \%$ of the surface lots surrounding O'Brien Lake. In 1913, the Hawkins concentrator washed about 7,000 tons of ore per day and employed 60 men. Sellwood argued that if the injunction was upheld, Wisconsin Steel would either need to dismantle and relocate the Hawkins plant elsewhere, or rescind on the lease agreement that they signed, impacting the company financially to the sum of millions of dollars. ${ }^{39}$

By 1913, the industry estimated that more than one hundred million tons of washable ore could be mined in the western Mesabi. For this material to become merchantable, it needed to be processed, which required vast sums of water and produced vast sums of mine waste that would pollute local waters. In his affidavit, Sellwood admitted as much, stating that ore processing would lead to discolored waters because the company lacked the technology to prevent tailings dumped in one water body from moving into other water bodies. If the courts would not allow for the coloring of waters from mine waste, "many million tons of ore will necessarily lie dormant," Sellwood argued. ${ }^{40}$

Recognizing the importance of this case, Edgar Bancroft, the senior counsel for International Harvester (the owner of Wisconsin 
Steel), began providing the defense with further legal advice. Bancroft suggested the defense question the charge of "irreparable damage" brought about by the plaintiff. ${ }^{41}$ Attorneys for the defense began reviewing injunction cases that had been previously denied by the courts. The defense compiled a list of thirteen earlier cases where the court ruled in favor of the defense if it was shown that the defendant's property or business was of significant value, and the plaintiff's property was of little value. These cases would provide the defense with a legal precedent that argued if the financial damage sustained by the defendant "would be great as compared to the damage resulting to the plaintiff from a denial of the injunction," than history showed that the court should rule in favor of the defense. ${ }^{42}$ Because Munter's Swan Lake property taxes were low, Bancroft suggested that the defense lawyers argue that plaintiff had suffered no "substantial injury." ${ }^{43}$

\section{Technological Alternatives: The O’Brien ditch:}

Even as Sellwood argued in court that technological alternatives did not exist, the company was privately devising plans to stop the tailings from migrating into Swan Lake. On August 6th of 1913, company engineers suggested in internal memos that Wisconsin Steel “divert O’Brien Creek before it flowed into O’Brien Lake, and conduct it around O'Brien Lake by digging a trench around the east side of the Lake so that the creek will no longer flow through the Lake." ${ }^{44}$ Wisconsin Steel engineers further proposed "to dam the outlet of O'Brien Lake so that no water will hereafter flow out of it, thus preventing the water colored by the washing of ore, from getting into the Creek below the Lake, and into Swan Lake." ${ }^{45}$ In a memo to 
Wisconsin Steel's attorney, Bancroft argued that the proposed ditch might prevent lawsuits, because it could function as a technological solution that would alleviate future migration of tailings into Swan Lake, and prevent any future discoloring. Bancroft argued that the court would find that this planned ditch system proved that Wisconsin Steel was responding accordingly to the suit, and that the construction of the ditch and dams would make "it clear that there will be no substantial damage in the future." ${ }^{46}$

By October of 1913, the attorneys for Wisconsin Steel had collected affidavits from eleven other residents of Swan Lake and Nashwauk, whose written testimonies discredited arguments made by the plaintiffs. On October 17, 1913 a hearing for the temporary injunction was held in Duluth's Federal Court overseen by Judge Page Morris. During the hearing, the water samples collected by Batchelder and the plaintiff "were put on exhibit, those of the applicant bearing the tint of orangeade and those of the defendants a lighter color." ${ }^{\prime 7}$ In addition to the contested evidence about the history of lake discoloration, the judge had found financial arguments most persuasive. ${ }^{48}$ The attorneys for Wisconsin Steel had argued that if the court ruled in favor of Munter, it would be "preventing mining companies from washing their ore because waters of comparatively little use were affected and would seriously embarrass the mining of 100,000,000 tons." ${ }^{49}$ The state of Minnesota had been invited to comment on the case, and the state had agreed that pollution was a minor inconvenience that should not be allowed to harm the growing industry. Lyndon Smith, the State's Attorney General, declared "that the state would not feel justified in injuring so important an industry for so slight a cause." ${ }^{50}$ Judge Morris sided with the defense and 
denied the injunction. Yet Munter's attorney filed a motion to appeal the decision, which was granted.

A week after Munter's appeal was filed in 1913, another resident of Swan Lake named Nels Olander drafted a second injunction against Wisconsin Steel. Also represented by Victor Power, Olander's suit paralleled Munter's in many regards-but Olander's suit responded directly to the rumors of a ditch that Wisconsin Steel wished to construct to solve the problem with tailings. Olander, like Munter, sought an immediate stop to the discoloring of Swan Lake, arguing that Wisconsin Steel failed to use "proper care and due diligence" in the construction of the concentrator. Olander argued that the current tailings disposal method employed at the Hawkins concentrator could be modified to prevent the future migration of tailings. ${ }^{51}$ Yet Olander was skeptical about the ditch as a solution. His suit argued that if the ditch was constructed haphazardly, it could decrease the flow of water into Swan Lake. The ditch would "bottle up" O’Brien Lake, and make its waters so "unfit" for use at the Hawkins concentrator, "that they must be flowed out through the dam at the outlet" of O'Brien Lake and back into Swan Lake, to allow for fresh water to refill O'Brien Lake. ${ }^{52}$

Even though the judge and the state had refused to limit the mining company's pollution, the company nevertheless decided to move forward with the ditch, hoping perhaps to reduce the cost and time of future court challenges. A month after Judge Morris's denial of the Munter injunction, the construction of the O'Brien Creek ditch began. By December 1913, Wisconsin Steel was operating a steam shovel both day and night to excavate the ditch..$^{53}$ By January 1914, the ditch around O'Brien Lake was nearly complete. The ditch seemed to alleviate some local concerns about pollution from tailings. In fact, after the Olander ruling, attorney Victor Power announced that it was 
not in his client's "interest to begin another case, if it should prove that our ditch around O'Brien Lake will prevent discoloration of the water of Swan Lake (see Figure 5.5)." ${ }^{54}$

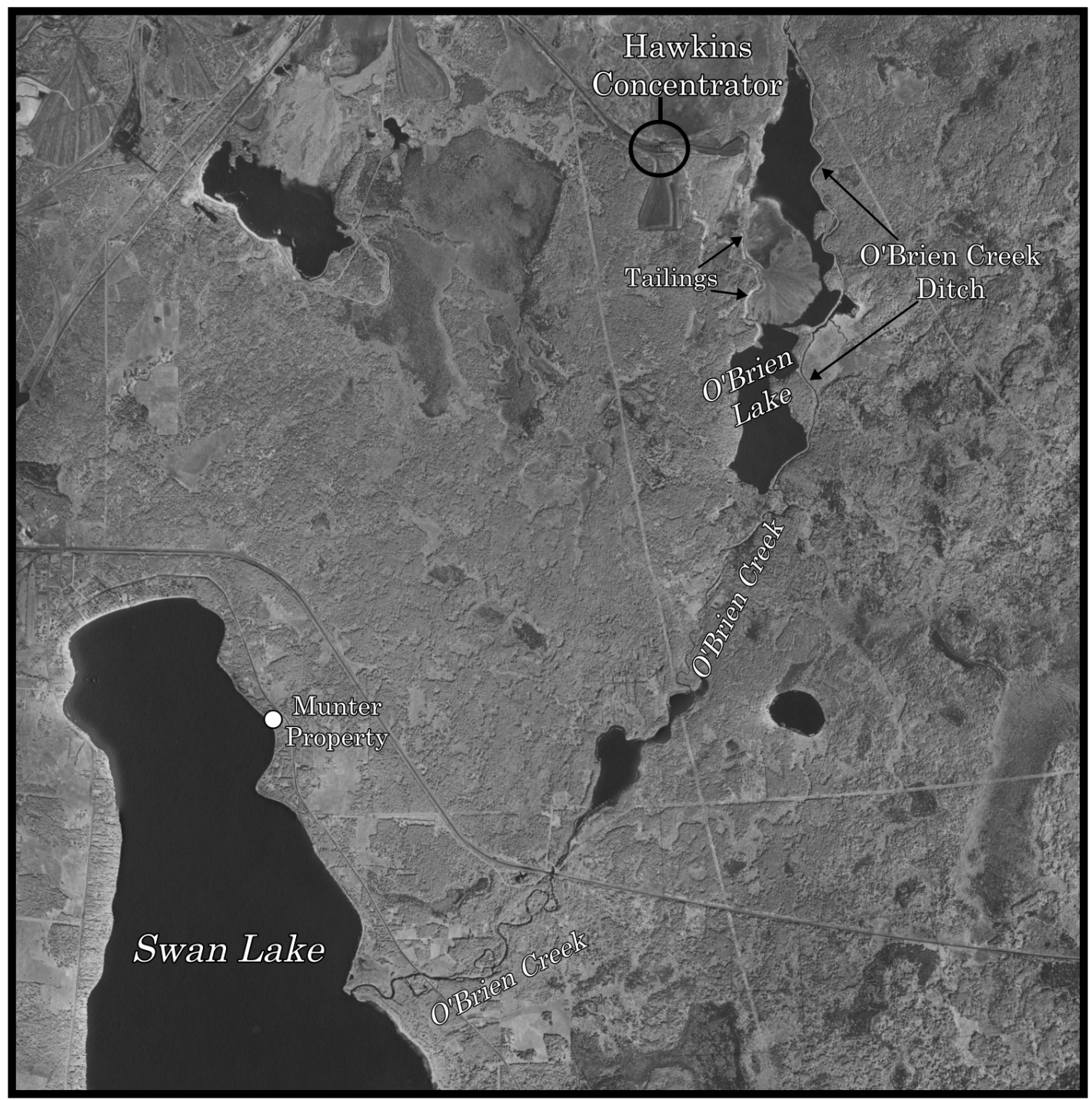

Figure 5.5: Aerial image of the Hawkins concentrator from 1947, showing O'Brien Creek Ditch, Munter's property, and spread of tailings (Adapted from Minnesota DNR Airphotos Online)

The ditch functioned as an ecosystem modification that would benefit Wisconsin Steel in two ways. First, by promising to prevent future discoloration of Swan Lake, the ditch addressed the concerns of 
Munter and Olander. Second, by removing the flow of water to and from O'Brien Lake, the ditch made O'Brien Lake a laboratory for tailings management. Removing the flow of O'Brien Creek allowed for a more controlled deposition of tailings, and this eventually provided Wisconsin Steel with more control over where their tailings would be located in case they wished to reprocess them in the future. ${ }^{55}$ By 1939, washable ore concentrating plants were discharging tailings with an iron content of anywhere from $12 \%$ - $37 \%$ iron. ${ }^{56}$ As engineers developed new ore-concentrating technologies, companies found they could profitably re-mine the old tailings deposited into lakes, recovering much of the ore value lost in the earlier concentration processes.

In 1913, the migration of tailings that moved from the launders of the Hawkins' concentrator, through O'Brien Lake, into O'Brien Creek, and eventually onto the banks of Swan Lake, resulted in the first instance of the public attempting to use legal avenues to prevent Mesabi mining companies from damaging private property and the environment. While Wisconsin Steel won the case, the company responded by deciding to construct the first tailings remediation structure in the Mesabi Range. The dike at O'Brien Lake's southern end blocked the route of migrating mine waste, a strategy the company pursued to lessen the chance of future lawsuits and to prevent future legal interventions into the mining company's day-to-day activities. This landscape alteration has had a lasting affect on the O'Brien Lake ecosystem, where it has outlived the concentrator for which it was built and the company who constructed it. 


\section{State Involvement with Mine Waste:}

The Munter v. Wisconsin Steel case was the first legal battle in Minnesota over the pollution of inland lakes from the dumping of mine waste, setting the stage for continued public concern. The state did not get involved in regulating the Swan Lake dispute, but by the early 1940s, enough public concern had been generated over tailings that Minnesota formed a conservation commission to balance the waste problems created from low-grade iron ore mining with their economic benefits. In 1940, the Oliver Iron Mining Co. was pressured by the State to stop dumping tailings into lakes and wetlands, and instead construct an inland tailings basin at their Trout Lake plant. ${ }^{57}$

Mining companies in the Mesabi Range resisted the construction of inland tailings basins, even as the state promoted them as technological solutions to the growing waste problem. In 1945, mining companies in the Mesabi Range persuaded the state legislature to allow companies to claim eminent domain over wetlands and inland lakes that could be turned into tailings dump sites. ${ }^{58}$ Minnesota conservationists were appalled. Led by the Izaak Walton League, conservation organizations began to push for regulatory changes in mining practices, seeking to prevent the seizure and destruction of more inland waters. The result was an empowered state Department of Conservation and Water Pollution Control Commission that gained the power to require mining companies to file for permits for tailings disposal.

In 1947, Reserve Mining Company filed a permit requesting to dump tailings from its Silver Bay taconite plant into Lake Superior. Reserve's lawyers argued that unlike many of the inland lakes that had become filled with tailings, the sheer size of Lake Superior made it impossible for this Great Lake to succumb to the same fate. Fearing 
possible damage to inland waters, the Izaak Walton League and the state Department of Conservation supported Reserve's permit, setting the stage for decades of conflict over the fate of iron ore tailings in Lake Superior. ${ }^{59}$

\section{Heritage Landscapes:}

The original Hawkins concentrator at O'Brien Lake was shut down and dismantled in 1952. ${ }^{60}$ From 1912-1951, the original Hawkins concentrator processed 18,719,321 tons of washable ore, and deposited an estimated 28-million tons of tailings into O'Brien Lake. ${ }^{61}$

The historical landscape of the Hawkins concentrator at O'Brien Lake has gone through a series of transformations, most recently functioning as a tailings basin for the Butler Taconite plant. Butler Taconite, a company that was operated by the Hanna Mining Co., had received permits from the Minnesota Department of Natural Resources (DNR) to deposit its taconite tailings in the O'Brien Lake valley in $1960 .{ }^{62}$ Butler Taconite dumped its tailings into the O'Brien Lake valley until it closed in 1985, after which, the Hanna Mining Co. became responsible for the reclamation of the area. By the early 1980s, all of the washable ore mines of the Mesabi Range had closed, and the beneficiation plants that processed their ores were shut down. For 70 years, the mining and processing of washable ores produced significant economic benefits in the Mesabi Range, as well as vast landscape changes. Iron mining remains an integral part of the Mesabi Range's heritage story, but how have the environmental legacies of mining been remembered?

The Mesabi's post World War II landscape saw the rapid development and expansion of taconite mines and processing plants, 
which created larger pits, consumed more water and produced significantly more tailings than their washable ore predecessors. ${ }^{63}$ This transition also witnessed a concerted effort by state agencies in promoting a new vision for the Mesabi Range as a recreational landscape reclaimed from the post-industrial. This effort prompted an increased focus on mineland reclamation throughout the Mesabi, and a subsequent erasure of much of the visible legacies of washable ore processing from the landscape.$^{64}$ A major project of this recreational transition was the conversion of former railroad lines into a paved biking and hiking path, called the Mesabi Trail. Along the Mesabi Trail visitors encounter interpretive signage, which highlight the adaptive re-use of the landscape. While the majority of the signs along the trail emphasize the region's mining heritage, only two signs mention either washable ore processing or the waste that they produced. The sign that describes washable ore tailings reads:

Tailings Basin: This reclaimed area holds red ore tailings from the Mountain Iron Mine washing plant operation. Tailings consist mainly of silica, which was removed from the mined iron ore to raise the iron content to maximize steel mill blast furnace operations. Tailings are not hazardous and were impounded to minimize the storage area.

Although informative, the message of this sign continues to perpetuate the benign narrative of iron mining and its environmental costs. While the tailings produced from washable ore processing in the Mesabi Range might not consist of the same hazardous materials contained in the arsenic-laden tailings produced at the Giant Mine in 
the Northwest Territories, they have, and continue to, significantly affect the environment, as seen at Swan Lake, whose waters are still turning red. ${ }^{65}$

In June, 2007 the Minnesota DNR received public comments regarding their environmental impact assessment of the Minnesota Steel Project, a proposed taconite mine and plant whose footprint would extend into the O'Brien Lake valley. ${ }^{66}$ While many of these public comments expressed support for the project, some were critical of the DNR's environmental impact assessment. A notable comment came from Richard Trebesch, a resident of Swan Lake, who voiced concern to the DNR about waters from the Minnesota Steel Project's tailings basin flowing into Swan Lake. The Minnesota Steel Project's proposed tailings basin happened to be located directly atop the historical location of the Hawkins plant, meaning that much of the tailings deposited by the taconite plant would eventually find their way into O'Brien Lake. In his letter, Trebesch describes witnessing the affect of tailing discharges from the Butler tailings basin migrating into Swan Lake in the 1980s, stating, "I can attest to the water quality damage done to Swan Lake by draining the O'Brien Lake watershed into Swan. The amount of debris and silt that was discharged into Swan was appalling and literally changed the color of the lake." ${ }^{67}$ Members of the Minnesota DNR acknowledged that Trebesch's concerns were voiced by other members of the Swan Lake community, stating, "Many residents recall times of 'red' water affecting the entire lake from Butler taconite operations (assumed to come from tailings leakage, pit pumping and/or process water disposal)." 68

In the DNR's environmental impact assessment of the Minnesota Steel Project no mention is made of the Hawkins concentrator or the 42 years that it processed washable ores and dumped tailings into 
O'Brien Lake, showing how quickly heritage legacies can become erased from our collective knowledge. Of the 88 washable ore concentrating plants that operated on the Mesabi Range, only thirteen remain visible today, while the rest exist as ghosts on the landscape. ${ }^{69}$ These ghost plants are visibly absent, yet environmentally persistent, evident in the abundance of landscape modifications, piles of mine waste, and more latent contamination that continues to interact with the environment. And while the histories of these ghost plants may have faded from memory, their environmental legacies remain embedded in the landscape.

Sometime after 1947, the waters running from O’Brien Creek were rechanneled back into O'Brien Lake. The ditch that appears clearly in aerial imagery from 1947 disappears in similar aerial images from 1989. However, a new landscape modification, a dike running across the southern reaches of Little O'Brien Lake now stands out. Butler Taconite constructed this dike in 1964, to function as a retaining dam, to prevent the tailings produced by Butler Taconite, and the waters of O'Brien Lake, from flowing into Swan Lake.

At O'Brien Lake, where the Hawkins concentrator was dismantled in 1952, a large polygonal tailings basin, more than 1,600 acres in size, now dominates the landscape. From above, the Butler Taconite tailings basin appears as a gray horizontal plane, devoid of nearly any surface topography, but when examined closer a distinct linear pattern emerges at the basin's northern extent, along with alluvial fanning, a characteristic landscape feature produced from waste discharge (see Figure 5.6). The linear feature is the remnant of the railroad mound that once approached the Hawkins plant, while the alluvial fans consist of the waste rock dumps and surface tailings which failed to make their way into O’Brien Lake. Analyzing the 
surface of this same landscape with LiDAR data further highlights the persistence of the Hawkins concentrator, as the footprint of the structure even begins to reveal itself.

The most notable surface legacy of low-grade ore processing at O'Brien Lake remains the southern dike constructed by Butler Taconite to prevent its tailings from spreading into the broader Swan Lake ecosystem. This dike, which is nearly two-miles in length and 300-feet in width, continues to function as a barrier, albeit unsuccessfully, more than 20-years after the mining company that built it dissolved.

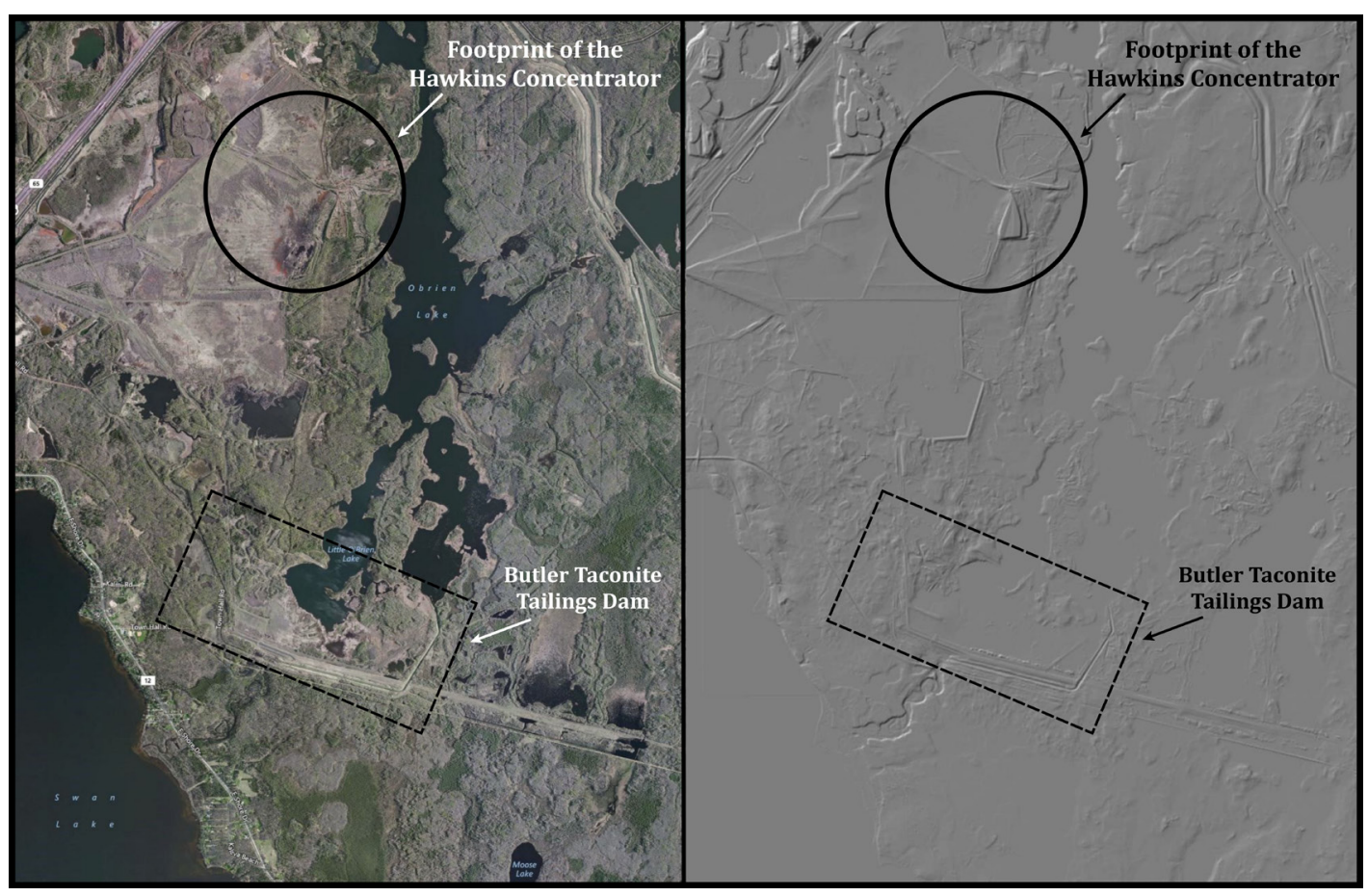

Figure 5.6: The modern landscape of the Hawkins concentrator comparing aerial imagery and LiDAR Data (MNTOPO)

\section{Conclusion:}

The beneficiation of low-grade ores produced tremendous economic benefits for the Mesabi Range and the nation, but these technologies also created lasting environmental consequences. Lowgrade iron ore mining brought the impacts of mining into the 
backyards of communities, creating visible blights on the heels of industrial prosperity. The Munter injunction forced the mining industry to defend its presumed right to pollute and devise a ditch system to prevent the spread of tailings into Swan Lake. Yet mining companies continued to dump tailings into inland water bodies for the next three decades, until mining companies were pressured to develop surface tailings basins. ${ }^{70}$

The mining industry placed the mining and processing of lowgrade ores within the framework of the conservation movement. By targeting deposits of low-grade ores, Mesabi mining companies argued that the demand on high-grade direct shipping ores would be lessened, and allow for use by future generations. ${ }^{71}$ But the mining and processing of low-grade ores also resulted in new conservation problems for future generations to contend with, such as concerns voiced by Trebesch and other Swan Lake residents over the lake's continual discoloring.

Although it lacks the structures and machines characteristic of an ore processing landscape, the modern landscape of the Hawkins concentrator reflects complex envirotechnical transformations. The absence of material structures and technologies at this site does not take away from its lasting affect on the landscape, nor its heritage importance. ${ }^{72}$ In mining landscapes, such as the Mesabi Range, the valueless by-products of mining were deposited either at the mines or near the concentrating plants, while the valuable ore and mining profits were exported out of the region. Since the majority of the concentrating plants located in the Mesabi were scrapped decades ago, these by-products, such as tailings basins, function as some of the last physical vestiges of the Range's industrial past. 
Waste and contamination are some of the most ubiquitous legacies produced from mining and ore processing, yet these artifacts are often hidden from the public's view. The dynamic nature of a mining landscape, which undergoes successive phases of re-work and abandonment, makes it difficult to track where, what and when these artifacts of contamination were produced. Furthermore, in the Mesabi Range, a lack of heritage interpretation has helped dematerialize the legacies of low-grade iron ore processing, affecting the region's collective memory, and making opaque the historical timeline of environmental transformations that were wrought from low-grade iron ore processing. 


\section{Acknowledgements:}

This work was supported by the National Science Foundation (Grant \#R56645, Toxic Mobilizations in Iron Mining Contamination). Nancy Langston at Michigan Tech provided considerable feedback and support. I also thank the staff at the Gale Family Library and the Minnesota Historical Society for assistance with the Kellogg, Davis and Severance papers. 


\section{Works Cited:}

${ }^{1}$ Walter Thurman, Waste Dumps of the Mesabi Range: Heritage or Blight? (Master's Thesis: St. Cloud State University, 1992); John Baeten, "Contested Landscapes of Displacement: Oliver Iron and Minnesota's Hibbing District," Change Over Time: An International Journal of Conservation \& the Built Environment (Forthcoming, Fall 2017). 2 “The Iron Ore Dilemma," Fortune, December 1945.

${ }^{3}$ Stuart Harrison, "Where Is the Iron Ore Coming From?," Financial Analysts Journal 9, no. 3 (June 1953).

${ }^{4}$ David A. Walker, Iron Frontier: The Discovery and Early Development of Minnesota's Three Ranges (St. Paul, MN: Minnesota Historical Society, 1979).

${ }^{5}$ John Baeten, Nancy Langston, and Don Lafreniere, “A Geospatial Approach to Uncovering the Hidden Waste Footprint of Lake Superior's Mesabi Iron Range," The Extractive Industries and Society, Vol.3, Issue 4, (November, 2016) 1031-1045.

${ }^{6}$ John Thistle and Nancy Langston, "Entangled histories: Iron ore mining in Canada and the United States," Extractive Industries and Society, Vol.3, Issue 2 (April, 2016) 269-277. Also see Nancy Langston, Sustaining Lake Superior: An Extraordinary Lake in a Changing World (New Haven: Yale University Press, 2017). ${ }^{7}$ Jeff Manuel, Taconite Dreams: The Struggle to Sustain Mining on Minnesota's Iron Range, 1915-2000 (Minneapolis: University of Minnesota Press, 2015); and Langston (see note 6). For literature regarding the use of the environment as a 'sink' for industrial waste, see Martin Melosi, “'Out of Sight, Out of Mind' The Environment and Disposal of Municipal Refuse, 1860-1920, The Historian, Vol. 35, Issue 4 (1973) 621-640; and Joel Tarr, The Search for the Ultimate Sink: 
Urban Pollution in Historical Perspective (Akron: University of Akron Press, 1996).

${ }^{8}$ Fredric Quivik, Smoke and Tailings: An Environmental History of Copper Smelting Technologies in Montana, 1880-1930 (Ph.D. dissertation: University of Pennsylvania, 1998); Kathryn Morse, The Nature of Gold: An Environmental History of the Klondike Gold Rush (Seattle: University of Washington Press, 2003); Liza Piper, "Subterranean Bodies: Mining the Large Lakes of North-west Canada, 1921-1960," Environment \& History, Vol. 13, No. 2 (May, 2007) 155186; Thomas Andrews, Killing for Coal: America's Deadliest Labor War (Cambridge: Harvard University Press, 2008); Timothy LeCain, Mass Destruction: The Men and Giant Mines that Wired America and Scared the Planet (New Brunswick: Rutgers University Press, 2009); Kent Curtis, Gambling on Ore: The Nature of Metal Mining in the United States, 1860-1910 (Boulder: University of Colorado Press, 2013); and John R. McNeill and George Vrtis (eds.), Mining North America: An Environmental History since 1522 (Berkley: University of California Press, 2017).

${ }^{9}$ Duane Smith, Mining America: The Industry and the Environment, 1800-1980 (Boulder: University of Colorado Press, 1987); Richard Francaviglia, Hard Places: Reading the Landscape of America's Historic Mining Districts (Iowa City: University of Iowa Press, 1991). The transformation of the mining landscape from technological change is also covered in Peter Goin and Elizabeth Raymond, Changing Mines in America (Santa Fe: The Center for American Places, 2003).

${ }^{10}$ LeCain (see note 8).

${ }^{11}$ Daviken Studnicki-Gizbert and David Schecter, "The Environmental Dynamics of a Colonial Fuel-Rush: Silver Mining and Deforestation in 
New Spain, 1552-1810," Environmental History, Vol. 15, No. 1, (January, 2010) pp. 94-119.

${ }^{12}$ Quivik (see note 8); LeCain (see note 8); Timothy LeCain, “The Limits of Eco-Efficiency: Arsenic Pollution and the Cottrell Electrical Precipitator in the US Copper Smelting Industry," Environmental History, Vol. 5, No. 3 (July, 2000) pp. 336-351. Bode Morin, The Legacy of American Copper Smelting: Industrial Heritage versus Environmental Policy (Knoxville: University of Tennessee Press, 2013); Marianne Sullivan, Tainted Earth: Smelters, Public Health, and the Environment (New Brunswick: Rutgers University Press, 2014). ${ }^{13}$ Walker (see note 4); Manuel (see note 7); Terry Reynolds and Virginia Dawson, Iron Will: Cleveland-Cliffs and the Mining of Iron Ore, 18472006 (Detroit: Wayne State University Press: 2011). ${ }^{14}$ Martin Melosi, "The Fresno Sanitary Landfill in an American Cultural Context," The Public Historian, Vol. 24, No. 3 (Summer 2002) pp. 17-35; Fredric Quivik, "The Historical Significance of Tailings and Slag: Industrial Waste as Cultural Resource," IA: The Journal of the Society for Industrial Archaeology, Vol. 33, No. 2 (2007) pp. 35-52.

${ }^{15}$ Quivik, (see note 14) 49.

${ }^{16}$ Donald Hardesty, "Issues in Preserving Toxic Wastes as Heritage Sites," The Public Historian, Vol. 23, No. 2, (Spring, 2001) 19-28, 20. ${ }^{17}$ Arn Keeling and John Sandlos, Mining and Communities in Northern Canada: History, Politics, and Memory (Calgary: University of Calgary Press, 2015)

${ }^{18}$ Keeling and Sandlos (see note 17) 379.

${ }^{19}$ Craig E. Colton, "Waste and Pollution: Changing Views and Environmental Consequences," The Illusory Boundary: Environment and Technology in History, 184-185. 
${ }^{20}$ Munter V. Wisconsin Steel Company, Internal Correspondence, Davis, Kellogg \& Severance Law Firm Collection, 149.B.19.5B, Box 52, Folder 3074, Minnesota Historical Society (Dec. 9, 1913). 21 "By the Way," Engineering and Mining Journal, Vol. 97, No. 5 (Jan. 31, 1914) 293-294. 22 "Dago Red" was a derogatory term for cheap red Italian wine. 23 "Hawkins Mine Shops Ready," The Virginia Enterprise, Vol. 23, No. 51 (February 05, 1915) 1.

${ }^{24}$ Munter v. Wisconsin Steel Company, “Notice," Davis, Kellogg \& Severance Law Firm Collection, 149.B.19.5B, Box 52, Folder 3074, Minnesota Historical Society (June 7, 1913). ${ }^{25}$ Ibid., 1.

${ }^{26}$ Munter v. Wisconsin Steel Company, “Complaint," Davis, Kellogg \& Severance Law Firm Collection, 149.B.19.5B, Box 52, Folder 3074, Minnesota Historical Society (June 7, 1913) 2.

${ }^{27}$ Munter (see note 24) 4.

${ }^{28}$ Munter v. Wisconsin Steel Company, "Munter Affidavit," Davis, Kellogg \& Severance Law Firm Collection, 149.B.19.5B, Box 52, Folder 3074, Minnesota Historical Society (June 9, 1913).

${ }^{29}$ We know today that this rule of thumb does not always work, but in 1913, discoloration suggested contamination.

${ }^{30}$ Munter v. Wisconsin Steel Company, "Sellwood Answer," Davis, Kellogg \& Severance Law Firm Collection, 149.B.19.5B, Box 52, Folder 3074, Minnesota Historical Society (August 13, 1913) 9.

${ }^{31}$ Munter (see note 28) 8.

${ }^{32}$ Munter v. Wisconsin Steel Company, "Batchelder Affidavit," Davis, Kellogg \& Severance Law Firm Collection, 149.B.19.5B, Box 52, Folder 3074, Minnesota Historical Society (October 16, 1913).

${ }^{33}$ Munter (see note 30) 9. 
${ }^{34}$ Munter (see note 30) 11-12.

${ }^{35}$ Dennis H. Schupp, “An Ecological Classification of Minnesota Lakes With Associated Fish Communities," Minnesota Department of Natural Resources Investigational Report \#417 (1992).

${ }^{36}$ Munter (see note 28).

${ }^{37}$ Ibid, pp. 6-7.

${ }^{38}$ Ibid., 3.

${ }^{39}$ Ibid.

${ }^{40}$ Ibid., 6.

${ }^{41}$ Munter v. Wisconsin Steel Company, "Bancroft Correspondence," Davis, Kellogg \& Severance Law Firm Collection, 149.B.19.5B, Box 52, Folder 3074, Minnesota Historical Society (October 16, 1913).

${ }^{42}$ Munter v. Wisconsin Steel Company, "Defendant's Authorities," Davis, Kellogg \& Severance Law Firm Collection, 149.B.19.5B, Box 52, Folder 3074, Minnesota Historical Society (October 16, 1913). This type of document is often referred to as a balancing doctrine. For a detailed analysis of these types of legal documents see: Christine Rosen, "Differing Perceptions of the Value of Pollution Abatement across Time and Place: Balancing Doctrine in Pollution Nuisance Law, 1840-1906," Law and History Review, Vol. 11, No. 2 (Autumn, 1993) 303-381; and Christine Meisner Rosen, “'Knowing' Industrial Pollution: Nuisance Law and the Power of Tradition in a Time of Rapid Economic Change, 1840-1864," Environmental History, Vol. 8, No. 4 (Oct., 2003) pp. 565-597.

${ }^{43}$ Munter v. Wisconsin Steel Company, "Correspondence between Bancroft and Kellogg," Davis, Kellogg \& Severance Law Firm Collection, 149.B.19.5B, Box 52, Folder 3074, Minnesota Historical Society (October 8, 1913). 
${ }^{44}$ Munter V. Wisconsin Steel Company, "Correspondence between Philip Post and Baldwin," Davis, Kellogg \& Severance Law Firm Collection, 149.B.19.5B, Box 52, Folder 3074, Minnesota Historical Society (August 6, 1913) 1.

${ }^{45}$ Ibid.

${ }^{46}$ Munter V. Wisconsin Steel (see note 43), 1.

${ }^{47}$ The Virginia Enterprise, Vol. 22, No. 45 (October 17, 1913) 4.

${ }^{48}$ The Virginia Enterprise, Vol. 22, No. 45 (October 17, 1913) 4. ${ }^{49}$ Ibid.

50 "Editorial," Engineering and Mining Journal, Vol. 96, No. 17 (October, 1913).

${ }^{51}$ Olander v. Wisconsin Steel Company, "Complaint," Davis, Kellogg \& Severance Law Firm Collection, 149.B.19.5B, Box 52, Folder 3074, Minnesota Historical Society (October, 1913) 4.

${ }^{52}$ Ibid., 6-7.

53 "Digging Ditch Around Lake", The Virginia Enterprise, Vol. 22, No. 34 (Dec. 19, 1913) 19.

${ }^{54}$ Olander v. Wisconsin Steel Company, “Correspondence," Davis, Kellogg \& Severance Law Firm Collection, 149.B.19.5B, Box 52, Folder 3074, Minnesota Historical Society (January, 1914).

${ }^{55}$ The Engineering and Mining Journal, Vol. 163, No. 12 (December 1962) 152. Cleveland Cliffs, who purchased the property in 1947 , eventually reprocessed the tons of tailings residing within O'Brien Lake in the early 1960s.

${ }^{56}$ T.B. Counselman, "Dollars in Current Tailings of Mesabi Washing Plants," Engineering and Mining Journal, Vol. 140, No. 4 (April, 1939) 34-36.

57 “Trout Lake Ore Washer Improvements”, in Skillings' Mining Review, Vol. 28, No. 48 (March 23, 1940) 9. 
${ }^{58}$ Langston (see note 6).

${ }^{59}$ Langston (see note 6).

${ }^{60}$ Skillings' Mining Review, Vol. 52, No. 22 (June 1, 1963) 6.

${ }^{61}$ The Engineering and Mining Journal, Vol. 163, No. 12 (December 1962) 152. In 1947, the Cleveland-Cliffs Mining Company purchased the Hawkins property from International Harvester, including the mine and concentrator.

${ }^{62}$ Dan Chilton, "Watershed reclamation at Butler Taconite, under Minnesota DNR "Rules related to mineland reclamation"," Chapter 6130-6130.01-6130.63, Achieving land use potential through reclamation, Proceedings of the $9^{\text {th }}$ annual national meeting of the American Society for Surface Mining and Reclamation (1992).

${ }^{63}$ Manuel (see note 7); Langston (see note 6).

${ }^{64}$ Baeten (see note 1 ).

${ }^{65}$ Liza Piper, The Industrial Transformation of Subarctic Canada (Vancouver: University of British Columbia Press, 2010); Keeling and Sandlos (see note 17).

${ }^{66}$ Minnesota Department of Natural Resources, Minnesota Steel Draft Environmental Impact Statement (February, 2007).

${ }^{67}$ Richard Trebesch, "Minnesota Steel," EIS Record of Decision, Final EIS Comment Letters (1), Minnesota Steel Draft Environmental Impact Statement, Minnesota Department of Natural Resources (February, 2007).

${ }^{68}$ Minnesota Department of Natural Resources (see note 67), Appendix $M$.

${ }^{69}$ The 'ghost plant' metaphor draws on John Sandlos and Arn Keeling's description of 'zombie mines', from: John Sandlos \& Arn Keeling, "Zombie Mines and the (Over)burden of History", Solutions, Vol. 4, Issue 3 (May, 2013) 80-83; as well as an investigative report into 
historic lead smelters: Alison Young \& Peter Eisler, "Ghost Factories: Poison in the Ground," USA Today (April 25, 2012).

${ }^{70}$ Around 1940, the state pressured U.S. Steel to construct an inland tailings basin for its Trout Lake concentrator, which is believed to be the first functioning tailings basin on the Mesabi Range.

${ }^{71}$ Carl Zapffe, "Trend of Ore Treatment and its Bearing on Lake Superior Iron Ore Reserves," The Mining Congress Journal (January, 1936); Alfred Eckes, The United States and the Global Struggle for Minerals (Austin: University of Texas Press: 1979).

${ }^{72}$ For literature exploring the heritage of absence see: Mikkel Bille, et al., (eds.), An Anthropology of Absence: Materializations of Transcendence and Loss (New York: Springer, 2010); and Gaston Gordillo, Rubble: The Afterlife of Destruction (Durham: Duke University Press, 2014). 


\section{Conclusion: A Mine is More Than a Hole in the Ground}

The chapters in this dissertation address the landscape-scale transformations that accompanied technological shifts in iron ore mining within the Lake Superior iron district, and specifically Minnesota's Mesabi Range. The dissertation asks a number of landscape-based questions: how has mining in the Lake Superior basin impacted the environment, how have communities responded to these impacts, what environmental legacies produced from mining remain on the landscape, and what elements of mining have been memorialized or forgotten by heritage organizations? Throughout the dissertation, I argue that industrial heritage coupled with environmental history can be used to inform current policy directives.

As an archaeologist, my analytical purview focuses on broad landscapes, rather than individual artifacts - and among these landscapes, I have found the ones that experienced mining the most interesting. Reading a mining landscape, you quickly learn that a mine is much more than a hole in the ground. Rather, a mine is a complex envirotechnical system, consisting of points of extraction and ore processing, flows of transportation networks and environmental modifications, and tremendous footprints of waste. In developing the HGIS dataset used throughout this dissertation, I wanted to include how these complex systems would have shaped and appeared on the landscape, both historically and as they do today.

This process began with inventorying what existed on the historic mining landscape, a process that was streamlined owing to the existence of an historic mine location dataset managed by the USGS. However, during the development of the HGIS I became aware of a glaring problem: no existing US government dataset has tracked the 
location or function of ore processing facilities, not just in the Lake Superior basin, but across North America. This oversight means that although we know where the hole in the ground is, we know much less about the facilities that processed ores, consumed vast sums of water, and produced tailings. In mapping and reconstructing the historic landscape of beneficiation across the Lake Superior district, I provide a methodology that others can apply to understand the historical location and impact of ore processing sites.

Identifying the extent of ore processing facilities in the Lake Superior basin shows how historic datasets can be used to inform our understanding of modern landscapes. Mapping also provides land managers and policy makers with an approach that they can apply to address current challenges and objectives. The dissertation argues that although the locations of mines in North America have been tracked, their landscape impacts have not been tracked as carefully. Specifically, for better regulation of historic mining impacts, it is important to know the locations of historic ore processing facilities and waste sites. Such mapping allows one to track the environmental impacts that of historic mine processing, particularly in water consumption and waste production.

This dissertation highlights how historical datasets can be coupled with current environmental datasets to better inform environmental scientists about potential legacy effects that might exist within a given landscape. Chapter 3 compares current impaired waters data with historic iron mining intensity, identifying gaps in the impaired waters assessments carried out by the Minnesota Pollution Control Agency (MPCA). Although MPCA staff have assessed a large proportion of lakes within the watersheds that surround the Mesabi Range, they have assessed less than 5\% of mine-pit lakes, and they 
have avoided surveying those waterbodies located within HUC-12 subwatersheds that have experienced taconite mining and ore processing. This finding leads to two policy suggestions for the MPCA. First, the agency should assess more lakes and rivers within the mining ranges. Second, the agency should seek out historical datasets prior to assessing waterbodies. Understanding the industrial history of a watershed would not only provide a better cultural context of a lake or river, but it could assist the MPCA in targeting waterbodies that may contain higher concentrations of legacy pollutants.

Environmental scientists could benefit from approaches used by archeologists to understand sites. When archeologists prepare for an archaeological survey, one of their first tasks is conducting background research into the history of the landscape they are going to investigate. This background work provides an historic context to the survey, familiarizing researchers with what occurred within that landscape and providing information regarding what they might find during survey work. Such historic surveys would be useful for regulatory agencies such as the MPCA..

By using a landscape-scale approach to analyze and interpret the Mesabi mining landscape, this dissertation argues that many historical elements that had seemingly been forgotten can be illuminated. Constructing a comprehensive HGIS not only revealed the many short lived mines and processing plants once operated across the Lake Superior district, but it also highlighted the amount of intense industrial activity that had yet to be approached through the lens of mining history, historical geography, or industrial heritage. More than 70 washable ore processing plants once functioned across the Mesabi Range, consuming billions of gallons of water and producing millions of tons of waste, yet we see that the beneficiation 
of washable ores in the Mesabi Range had received little, if any, scholarly attention. This void is also apparent within the region's heritage discourse, where washable ores and ore processing facilities have taken a back seat to open-pit mines and taconite technologies. All of this equates to a need for more research into the region's history.

The context in which this dissertation began is important to highlight. I began researching historic mining in the Lake Superior basin in the fall of 2014, roughly one month after the Mount Polley tailings disaster and a year prior to the Gold King mine disaster in 2015. At this time it became clear to me that environmental disasters resulting from failed mining technologies were a growing contemporary concern. I also realized that the field of industrial heritage and archaeology was not addressing this concern. Few professionals in industrial archaeology or industrial heritage articulated how their understanding of historic technologies, landscapes, and systems could provide a context to why these disasters occurred, or try to identify what might prevent more of these disasters occurring in the future. I wanted to address this omission, so mine waste and the environmental legacies produced from mining became a focus of this research.

With more than a half-million abandoned mines in North America, future tailings disasters are probable. Additionally, many of the historic ore processing facilities and waste management structures that accompany these abandoned mines were not engineered with climate change in mind. While this research identify the extent of ore processing and waste across the Lake Superior iron district, there remains much work to identify the extent of mine waste across North America and across the globe. 
This dissertation argues that the environmental legacies produced from mining in the Mesabi Range are significant on a landscape scale. When analyzing contemporary aerial imagery of Northern Minnesota, the Mesabi Range stands out as a brown ' $z$ ' shape amongst a sea of green vegetation. While the aerial survey reveals the obvious quantity of waste on the landscape, its prevalence is much less clear on the landscape, where regrowth of forests and reclamation have obscured many waste piles. Similarly, within the region's heritage discourse, the development of a heritage tourism industry has obscured the extent and importance of iron processing and waste.

The dissertation argues that state agencies attempted to erase many of the visible signs that accompanied deindustrialization efforts by transforming the Mesabi Range into a recreational landscape, which resulted in the removal of thousands of mine buildings, the recontouring of mine waste piles, and widespread revegetation. Similarly, Mesabi Range industrial heritage organizations focused their attention on promoting the region's technological achievements in mining and the region's continual mining success, rather than acknowledging the ubiquitous and widespread waste footprint that spread across the region. These findings are not entirely surprising. Reclamation efforts are aimed at cleaning up a mining landscape, while industrial heritage organizations have been primarily concerned with attempting to attract visitors and tourism. However, these efforts to revitalize a post-industrial economy have not only obscured many of the environmental impacts from mining, they have also promoted many of the area's resources as being either pristine or pure. When environmental legacies from mining are removed from the landscape and erased from memory, a dangerous cycle of forgetting can begin. The dissertation argues that a critical heritage perspective focused on 
recognition and interpretation can help address this cycle of forgetting.

Building off of critical heritage concepts, such as presence of absence, intangibility, and hurtful heritages this dissertation explores the significance of forced community abandonment from industrial expansion, the environmental persistence of former "ghost" concentrating plants, and the cultural value of toxicity and waste. I plan to continue examining these themes in my future research. The official recognition and memorialization of cultural heritage sites that have experienced hurtful pasts, such as the Auschwitz concentration camp, have proven to be globally important and successful UNESCO World Heritage Sites. During the 2016 year alone, Auschwitz received more than 1.72 million visitors, showing that nostalgia alone does not drive the heritage tourism industry. These places with hurtful pasts give visitors the chance to reflect on the cruelty, violence, and devastation that humankind has carried out against each other in the name of politics, religion, and power. However, sites that give visitors the opportunity to reflect on the violent, traumatic and destructive relationships that humankind has carried out in the name of industrialization, such as at Bhopal, Texas City, Love Canal, Baia Mare, and Chernobyl, have yet to receive a similar type of official heritage recognition from global entities like UNESCO. This gap in recognition can serve as an excellent avenue for industrial heritage professionals to collaborate with environmental scientists. Sites where industrial disasters occurred possess a tremendous amount of heritage value, and they could serve as excellent venues for visitors to reflect on technological failure, consumerism, and the use and abuse of natural resources. My future research will explore options for the global heritage recognition of these places. Industrial heritage can address 
these gaps in the global heritage recognition related to either industrial or environmental disasters, as well as the gaps in the recognition of environmental legacies produced from industrial processes at regional heritage sites.

This research argues that industrial heritage can be used to inform current environmental policy, and that using a critical environmental perspective can strengthen the field. When the next Gold King, Mount Polley, or Bento Rodriguez mine disaster strikes, critical industrial heritage perspectives can add to our collective understanding of not only why the disaster happened, but perhaps more importantly, how to prevent another disaster from occurring in the future. 


\section{Appendix A: Copyright Documentation}

Chapter 2: "A geospatial approach to uncovering the hidden waste footprint of Lake Superior's Mesabi Iron Range," was published in The Extractive Industries and Society, Vol. 3, Issue 4 (Nov. 2016). This manuscript is reprinted in accordance with the Author's Rights as outlined by Elsevier's Author and User Rights policy. Available at: $<$ https://www.elsevier.com/__data/assets/pdf_file/0007/55654/Auth orUserRights.pdf>

The following images in this document are reproduced here under either part of the creative commons, through fair-use due to copyright expiring and the image being in the public domain, or through fair use as approved by the institution that houses the material.

Figure 1.1: Lake Superior Iron District. This image was acquired from a USGS report: William Cannon, "The Lake Superior Iron Ranges: Geology and Mining," USGS Dept. of the Interior Report, a governmental source, and is used under a fair use agreement.

Figure 2.2: This figure was acquired through Minnesota Department of Natural Resources; MNTOPO Viewer Application $<$ http://dnr.state.mn.us/maps/mntopo/index.html>, a governmental service, and is used under a fair use agreement.

Figure 2.3: This figure was acquired through Minnesota Department of Natural Resources; MNTOPO Viewer Application <http://dnr.state.mn.us/maps/mntopo/index.html>, a governmental service, and is used under a fair use agreement. 
Figure 4.1: Overview of the Mesabi Range and the Hibbing Mining District. Figure accessed from the John R. Borchert Map Library at the University of Minnesota. Map of the Mesabi Range-Great Northern Iron Ore Properties, 1923, John R. Borchert Map Library at the University of Minnesota). This image is in the public domain due to copyright expiration, and is used here under a fair use agreement.

Figure 4.2: Overview of Hibbing and Carson Lake. Figure accessed from the John R. Borchert Map Library at the University of Minnesota. “Geologic Map of the Mesabi District, MN," USGS Monograph No. 43. This image is in the public domain.

Figure 4.3: North Hibbing, circa 1920. Figure was accessed and used with permission from the Gale Family Library at the Minnesota Historical Society. “Re: Hibbing Injunction Case, 1919-1922,” Davis, Kellogg \& Severance Law Firm Records, 147.C.1.1B.; Box 80; Folder 3813.

Figure 4.4: Mapped landscape change in Hibbing, 1921, 1951 and 1983 (Iron Trade Review, 1921; USGS Hibbing, MN Quadrangles 1951 and 1983). This compilation of images are in the public domain, as the USGS maps are government documents, and used under a fair use agreement, while the image from the Iron Trade Review is from 1921, and its copyright is expired.

Figure 4.5: Open-pit mine encroaching on North Hibbing, circa 1920. Figure was accessed and used with permission from the Gale Family Library at the Minnesota Historical Society. "Re: Hibbing Injunction Case, 1919-1922," Davis, Kellogg \& Severance Law Firm Records, 147.C.1.1B.; Box 80; Folder 3813. 
Figure 4.6: Overview of Carson Lake showing engineering plans: This figure is from the "The Draining of Carson Lake," The Engineering and Mining Journal, 97, No. 10, 1914. This image is in the public domain due to copyright expiration.

Figure 4.7: Relocation of the Carson Lake community. This figure was acquired through the Minnesota Department of Natural Resources, Airphotos Online < http://dnr.state.mn.us/airphotos/index.html > a government service, and is used under a fair use agreement.

Figure 5.3: The Hawkins Concentrator: This figure is from "Ore Washing Plant of the Wisconsin Steel Co.", Mining and Engineering World, July 13, 1912. This image is in the public domain due to copyright expiration.

Figure 5.4: Cross-section of the Hawkins: This figure was adapted from the article "Ore Washing Plant of the Wisconsin Steel Co.", Mining and Engineering World, July 13, 1912. This Image is in the public domain due to copyright expiration.

Figure 5.5: Aerial image of the Hawkins concentrator: This figure was acquired through the Minnesota Department of Natural Resources, Airphotos Online < http://dnr.state.mn.us/airphotos/index.html>, a governmental service, and is used under a fair use agreement. 
Figure 5.6: The Modern Landscape: This figure was acquired through Minnesota Department of Natural Resources; MNTOPO Viewer Application <http://dnr.state.mn.us/maps/mntopo/index.html>, a governmental service, and is used under a fair use agreement. 